Antonio Ruy de Almeida Silva

\title{
A DIPLOMACIA DE DEFESA NA SOCIEDADE INTERNACIONAL
}

TESE DE DOUTORADO

Tese apresentada como requisito parcial para obtenção do grau de Mestre pelo Programa de Pós-graduação em Relações Internacionais do Institituto de Relações Internacionais da PUC-Rio.

Orientadora: Prof $\stackrel{a}{ }$. Monica Herz 


\section{A Diplomacia de Defesa na Sociedade Internacional}

Tese apresentada ao Programa de Pós-graduação como requisito parcial para obtenção do título de Doutor em Relações Internacionais. Aprovada pela Comissão Examinadora abaixo assinada.

Profa. Monica Herz Orientadora e Presidente

Prof. Alcides Costa Vaz Universidade de Brasília

Prof. Antonio Jorge Ramalho da Rocha Universidade de Brasília

Prof. Eugenio Paccelli Lazzaroti Diniz Costa Departamento de Relações Internacionais - PUC Minas

Prof. Kai Michael Kenkel Instituto de Relações Internacionais - PUC-Rio

Profa.Monica Herz

Vice-Decana de Pós-Graduação do Centro de Ciências Sociais-PUC-Rio

Rio de Janeiro, 16 de março de 2014. 
Todos os direitos reservados. É proibida a reprodução total ou parcial do trabalho sem autorização da universisade, do autor e do orientador.

\section{Antonio Ruy de Almeida Silva}

O autor graduou-se em Ciências Navais pela Escola Naval e obteve, com distinção, em 1998, o Doutorado em Política e Estratégia Marítimas pela Escola de Guerra Naval. Realizou cursos no nível de mestrado na Escola Superior de Guerra Naval do Peru e no Naval War College, EUA. Possui, ainda, o diploma do Curso de Direito Internacional nos Conflitos Armados, ministrado pelo Instituto Internacional de Direito Humanitário, em San Remo, Itália. Em 2002, obteve o mestrado em Artes (Relações Internacionais) pela Salve Regina University, EUA. Suas áreas de interesse incluem Relações Internacionais, Segurança Internacional, Diplomacia, Poder Marítimo e Defesa Nacional.

Ficha Catalográfica

Silva, Antonio Ruy de Almeida

A diplomacia de defesa na sociedade internacional / Antonio Ruy de Almeida Silva ; orientadora: Monica Herz. $-2014$.

$194 \mathrm{f.} \mathrm{;} 30 \mathrm{~cm}$

Tese (doutorado)-Pontifícia Universidade Católica do Rio de Janeiro, Instituto de Relações Internacionais, 2014.

Inclui bibliografia

1. Relações internacionais - Teses. 2. Escola inglesa. 3. Sociedade internacional. 4. Diplomacia. 5. Segurança internacional. 6. Defesa. 7. Diplomacia de defesa. 7. Diplomacia militar. 8. Forças armadas. I. Herz, Monica. II. Pontifícia Universidade Católica do Rio de Janeiro. Instituto de Relações Internacionais. III. Título. 


\section{Agradecimentos}

À minha orientadora, Monica Herz, pela amizade, apoio, incentivo, críticas e orientações sobre esta tese e sobre as teorias das Relações Internacionais, que muito facilitaram minha jornada no doutorado e neste trabalho.

À PUC-Rio pelos auxílios concedidos, sem os quais este trabalho não poderia ter sido realizado

Aos professores do Instituto de Relações Internacionais da PUC-Rio, pelos ensinamentos tão bem transmitidos nas diversas disciplinas e pelos valiosos comentários que contribuíram para abrir meus horizontes para outras abordagens e para o aprimoramento desta tese: Carolina Moulin, João Nogueira, Kai Kenkel, Nizar Messari, Paulo Esteves e R.B.J Walker. Aos demais professores que me incentivaram e orientaram em diversos momentos: Adriana E. Abdenur, Fabiano Mielniczuk, José Maria Gomez, Letícia Pinheiro, Luiz Manuel Fernandes, Marta Fernandez Moreno, Nicholas Onuf e Sônia de Camargo.

Ao professor Steffano Guzzini, pelas conversas e orientações que muito me ajudaram no arcabouço teórico deste trabalho.

Aos professores Alcides Costa Vaz, Antonio Jorge Ramalho, Eugênio Diniz, Eurico Figueiredo, Francisco Carlos, Maria Celina D’Araújo, Nival Nunes de Almeida e Thomaz Guedes da Costa pela amizade, incentivo e ajuda em diversos momentos desta travessia.

Aos meus colegas e amigos do doutorado, sem os quais esta jornada teria sido muito mais difícil: Ana Saggioro, Layla Dawood, Márcio Scalércio ( parceiro e amigo desde as primeiras etapas desta caminhada), Natália Félix, Marcos Vinícius Figueiredo, Carlos Chagas e Jana Tabak. Um agradecimento especial a Maira Simon e Victor Lage, dois amigos que me ajudaram, inúmeras vezes, discutindo as questões teóricas das Relações Internacionais e a Lucas Fiorentino, que me ajudou na parte relativa às buscas na Internet e às dúvidas quanto à formatação da tese.

À equipe da secretaria do IRI, especialmente à Lia, Luciana, Vera, Geísa, Peterson, e Claudia que sempre me distinguiram com sua amizade e atenção.

À Carlos Augusto de Souza e Antonio Rafael Siqueira Santos, pela contribuição em determinados aspectos da pesquisa.

Aos meus pais e irmãos e à Elza, pelo carinho e pela amizade.

Aos meus filhos Erik e Andrey pelo amor e apoio incondicional.

À Thais, minha esposa e amiga, por ter tido a paciência de revisar este texto incansavelmente, mas, principalmente, pelo seu amor, sem o qual teria sido impossível chegar a um porto seguro. 


\section{Resumo}

Silva, Antonio Ruy de Almeida Silva; Herz, Monica (Orientadora). A Diplomacia de Defesa na Sociedade Internacional. Rio de Janeiro, 2014.194p. Tese de Doutorado - Instituto de Relações Internacionais, Pontifícia Universidade Católica do Rio de Janeiro.

Esta tese, fundamentada, principalmente, na Escola Inglesa, analisa o papel na sociedade internacional das práticas sociais relacionadas com o uso não coercitivo dos recursos do âmbito da Defesa entre os Estados e outras entidades que atuam na política internacional. As características, institucionalização, internacionalização, os fatores culturais e as críticas e tensões concernentes com essas práticas são descritas e examinadas, permitindo concluir-se que o fenômeno se constitui um tipo específico de diplomacia: a diplomacia de defesa, considerada como uma instituição da sociedade internacional.

\section{Palavras-chave}

Escola Inglesa; Sociedade Internacional; Diplomacia; Segurança Internacional; Defesa; Diplomacia de Defesa; Diplomacia Militar; Forças Armadas. 


\section{Abstract}

Silva, Antonio Ruy de Almeida Silva; Herz, Monica (Advisor). The Defense Diplomacy in International Society. Rio de Janeiro, 2014. 194p. Doctoral dissertation - Instituto de Relações Internacionais, Pontifícia Universidade Católica do Rio de Janeiro.

This doctoral dissertation, based, mainly, on the English School, analyzes the role in international society of the social practices related to non-coercive use of Defense's resources between states and other entities with standing in international politics. The features, institutionalization, globalization, cultural factors and criticisms and tensions related to these practices are described and discussed, allowing to conclude that the phenomenon is a particular kind of diplomacy: defense diplomacy, regarded as an institution of international society.

\section{Keywords}

English School; International Society; Diplomacy; International Security; Defense; Defense Diplomacy; Military Diplomacy; Armed Forces. 


\section{Sumário}

1 Introdução

2 Diplomacia como instituição 15

$\begin{array}{ll}2.1 & \text { Introdução } \\ & 15\end{array}$

2.2 A emergência da diplomacia 16

2.3 A diplomacia e a sociedade internacional 20

$\begin{array}{ll}\text { 2.3.1 A diplomacia e a escola inglesa } & 21\end{array}$

2.3.2 A sociedade internacional e as instituições 26

2.3.3 Funções da diplomacia 32

2.3.4 Os diplomatas e a cultura diplomática 34

2.4 A descentralização da diplomacia e as diplomacias setoriais 43

2.5 Conclusão 46

3 A institucionalização e a internacionalização da diplomacia de 48 defesa

3.1 Introdução 48

3.2 A institucionalização e a internacionalização 49

3.2.1 Mecanismos bilaterais e multilaterais 53

3.2.2 Ensino, pesquisa, treinamento e exercícios militares 76

$\begin{array}{ll}3.3 \text { Conclusão } & 84\end{array}$

4 Diplomacia de defesa 85

4.1 Introdução $\quad 85$

4.2 Abordagens teóricas e a diplomacia de defesa 85

4.3 Definição de diplomacia de defesa 95 
4.4 A diplomacia de defesa como uma instituição da sociedade internacional

4.4.1 A diplomacia de defesa como instituição

4.5 Conclusão

5 Militares e diplomatas: a questão cultural

5.1 Introdução

5.2 A cultura militar e sua relação com a cultura dos diplomatas

5.3 A cultura militar no pós-Guerra Fria

6 Críticas e tensões relacionadas com a diplomacia de defesa

6.1 Introdução

6.2 Desmilitarização da defesa e militarização da diplomacia

6.3 A ampliação do papel do Estado e a interdependência

6.4 "Whole of government approach"

6.5 A coordenação da diplomacia

6.6 Conclusão

7 Conclusão

7.1 Introdução

7.2 A institucionalização no âmbito da diplomacia de defesa 


\section{Lista de Siglas}

$\begin{array}{ll}\text { AFRICOM } & \text { Comando Militar dos EUA para a África } \\ \text { ASEAN } & \text { Associação das Nações do Sudeste Asiático } \\ \text { CASA } & \text { Comunidade Sul-Americana de Nações } \\ \text { CCPAG } & \text { Conselho de Cooperação para Países Árabes do Golfo } \\ \text { CDS } & \text { Conselho de Defesa Sul-Americano } \\ \text { CEI } & \text { Comunidade de Estados Independentes } \\ \text { CNI } & \text { Conferência Naval Interamericana } \\ \text { CPLP } & \text { Comunidade dos Países de Língua Portuguesa } \\ \text { EUA } & \text { Estados Unidos da América } \\ \text { GAO } & \text { United States Government Accountability Office } \\ \text { IBAS } & \text { Índia, Brasil e África do Sul } \\ \text { JID } & \text { Junta Interamericana de Defesa } \\ \text { MERCOSUL } & \text { Mercado Comum do Sul } \\ \text { OCS } & \text { Organização da Cooperação de Shangai } \\ \text { OEA } & \text { Organização dos Estados Americanos } \\ \text { ONGs } & \text { Organizações Não-Governamentais } \\ \text { ONU } & \text { Organização das Nações Unidas } \\ \text { OSCE } & \text { Organização para a Segurança e Cooperação na Europa } \\ \text { OTAN } & \text { Organização do Tratado do Atlântico Norte } \\ \text { RI } & \text { Relações Internacionais } \\ \text { RMDA } & \text { Reunião de Ministros da Defesa da ASEAN } \\ \text { RNIT } & \text { Rede Naval Interamericana de Telecomunicações } \\ \text { UA } & \text { União Africana } \\ \text { UE } & \text { União Européia } \\ \text { UNASUL } & \text { União das Nações Sul-Americanas } \\ \text { UND } & \text { Universidade Nacional de Defesa } \\ & \\ \text { ONa } & \\ \text { ONA } & \end{array}$




\section{Introdução}

O papel não coercitivo desempenhado na política internacional pelas Forças Armadas e, mais tarde, também pelos ministérios da Defesa, tem uma longa história, entretanto, tem sido pouco analisado nas Relações Internacionais (RI). Os trabalhos existentes, embora sejam contribuições importantes para o entendimento do tema, tratam esse fenômeno, normalmente, apenas no âmbito da cooperação, como um instrumento de política externa e de segurança ou como simples relações de poder. Alguns autores e documentos o conceituam de diversas maneiras, tais como diplomacia de defesa ou diplomacia militar, mas, no entanto, não aprofundam sua relação com a diplomacia em seu sentido mais amplo, considerada como prática social.

Assim sendo, o objetivo principal desta tese é buscar sanar essa lacuna em uma perspectiva sociológica, fundamentada, principalmente, na Escola Inglesa, mas engajando, sempre que necessário, outros desenvolvimentos teóricos das ciências sociais, já que a pesquisa de objetos de análise tão complexos requer uma abordagem interdisciplinar e uma metodologia pluralista. A escolha da Escola Inglesa se justifica, principalmente, por quatro motivos. Primeiro, porque ela, especialmente nos trabalhos dos seus autores clássicos, tem dado um destaque ao estudo da diplomacia como prática social e como uma instituição da sociedade internacional. Segundo, porque o fim da Guerra-Fria, além do incremento da globalização, tem sido um fator que contribui para o surgimento de outras questões para a teoria das Relações Internacionais. Apesar das ações unilaterais da potência hegemônica após 11 de setembro e da persistência do uso da força na política mundial, os mecanismos de governança continuam a ser criados e consolidados (BELLAMY, 2005, P.1-12). Nesse contexto, a Escola Inglesa, com a sua concepção de sociedade internacional, desponta como uma abordagem promissora para o entendimento, também, da política mundial no pós-Guerra-Fria, pela sua capacidade de conceber conceitualmente uma sociedade, com ideias, normas, regras e valores em uma moldura de Estados independentes com interesses próprios (FALK, 2005, P.195-196). Terceiro, porque essa Escola privilegia o papel do Estado na condução da diplomacia, e as práticas sociais a 
serem analisadas nesta tese se relacionam, basicamente, ao campo dos recursos de Defesa desses Estados. Finalmente, porque vários autores têm sugerido o incremento dos estudos empíricos para incorporar mais temas e atores que atuam na política mundial, relacionando-os com o conceito de sociedade internacional, a fim de aumentar a importante contribuição dessa Escola nas Relações Internacionais (BELLAMY,2005, P.1).

Desta forma, a tese tem como propósito principal entender a seguinte questão: qual o papel na sociedade internacional das práticas sociais, específicas de agentes oficiais, relacionadas com o uso não coercitivo dos recursos tangíveis e intangíveis do âmbito da Defesa entre os Estados e outras entidades que atuam na política internacional?

Embora seja impossível estabelecer fronteiras rígidas em relação ao fenômeno a ser estudado, analiticamente, é importante tentar delimitá-lo, mesmo que precariamente. Ele se constitui na política internacional, entendida como o ambiente onde se inter-relacionam os Estados e alguns outros atores com status nessa política, tais como a Organização das Nações Unidas (HOLSTI, 2004, P. $\mathrm{xv}$ ), e outras organizações ou mecanismos de segurança e defesa regionais ou inter-regionais. Os agentes oficiais são, fundamentalmente, autoridades públicas civis e militares do âmbito da Defesa, embora, dependendo do nível das práticas sociais, diplomatas e outros agentes possam também participar. As práticas estão relacionadas com o uso não coercitivo, entre os Estados e outras entidades, dos recursos humanos e materiais que os países dispõem no âmbito da Defesa. Algumas delas podem ter envolvimento com atores privados, particularmente, com Organizações Não-Governamentais (ONGs), porém o foco será sempre na interação entre os agentes oficiais acima referidos.

Delimitado o fenômeno e as abordagens teóricas sob as quais ele será analisado, é hora de tratar do desenvolvimento da tese, que terá seis capítulos, além desta introdução.

O Capítulo 2 descreve a emergência na modernidade das práticas diplomáticas como um fenômeno histórico-social, e analisa, fundamentado, principalmente, na Escola Inglesa, o papel da diplomacia considerada como uma instituição da sociedade internacional. Nesse movimento, o conceito de instituições de Bull (1995) é complementado pela visão de Giddens (1989) e de Searle $(1995,2008)$ sobre a maneira como as instituições são formadas e 
mantidas, e pelos critérios de Holsti (2004) para a existência de uma instituição, fortalecendo os argumentos que defendem a existência de uma ponte entre aquela Escola e o construtivismo. Em seguida, aborda-se a questão da comunidade diplomática com uma cultura comum. Finalmente, aponta-se para a possibilidade da existência de "diplomacias paralelas" (HILL, 2003; WATSON, 1982), das quais a diplomacia de defesa é um importante exemplo.

O capítulo seguinte descreve as principais práticas sociais relacionadas com o uso não coercitivo no âmbito da Defesa entre os Estados e outras entidades que atuam na política internacional, com o objetivo de identificar a sua amplitude e institucionalização, porém, sem a pretensão de fazer um inventário completo da sua disseminação, o que seria uma tarefa hercúlea e fugiria ao propósito desta tese. De forma semelhante ao que ocorre com as potências na diplomacia, neste caso, as militares, principalmente os Estados Unidos da América (EUA), possuem um papel importante nesse campo, já que elas, normalmente, interagem com um maior número de Estados, contribuindo para a constituição e disseminação das práticas e das normas no processo de socialização. Desta forma, essas potências terão, em determinados momentos, algum destaque neste capítulo e em outras partes deste trabalho. No entanto, os demais Estados e organizações internacionais, particularmente as regionais, desempenham um papel crucial nessa dinâmica e o que o texto busca mostrar é, fundamentalmente, como essas práticas, normas e regras estão disseminadas e institucionalizadas globalmente como um fenômeno que permeia a sociedade internacional.

O Capítulo 4 tem como propósito definir o fenômeno descrito no movimento anterior, fundamentado na discussão conceitual realizada no Capítulo 2. A primeira parte expõe as diferentes perspectivas de autores que analisam o tema. Alguns, com o propósito de sugerir uma maior atuação dos seus países no campo da cooperação militar como uma ferramenta de política externa (MUTHANNA, 2006), ou como uma diplomacia que representaria uma transição do papel das Forças Armadas do âmbito militar para o âmbito político, esmaecendo a distinção entre instrumentos militares e diplomáticos (DU PLESSIS, 2008). Outros, com a visão das potências ocidentais, para definir e defender o fenômeno como "exportação de segurança" (REVERON, 2010) ou para identificar uma "nova" diplomacia desenvolvida por essas potências no pósGuerra Fria (COTTEY E FOSTER, 2004). Finalmente, aqueles que enxergam o 
tema como categorias de práticas associadas às relações hierárquicas de poder (BARKAWI, 2011). Essa abordagens são importantes contribuições para o entendimento do tema, no entanto, elas não dão conta da complexidade do mesmo, e aquelas que o definem explicitamente, embora usem o termo "diplomacia", o fazem associando-o, normalmente, à cooperação. Assim, a segunda parte desse Capítulo define o fenômeno como uma diplomacia com características próprias, denominada diplomacia de defesa, a diferencia de outros conceitos normalmente utilizados em relação ao papel diplomático das Forças Armadas, e analisa como ela pode ser considerada uma instituição da sociedade internacional.

A Escola Inglesa considera que a cultura diplomática é um importante fator na constituição da diplomacia (BULL,1995). Desta forma, o Capítulo 5 trata da questão cultural relacionada com os diplomatas e os militares, com três objetivos principais: verificar as peculiaridades do relacionamento, diferenças e semelhanças entre eles; apontar para a existência de uma comunidade militar com uma cultura semelhante; e, finalmente, analisar, fundamentado basicamente na situação dos EUA, o aumento, no pós-Guerra Fria, da importância dos fatores culturais nas Forças Armadas e as possíveis consequências na cultura militar.

O processo da expansão da diplomacia de defesa, abrangendo novas tarefas, tem gerado críticas e tensões, especialmente nos EUA, onde, por um lado, surgem argumentos sobre a possível perda de capacidade combatente das Forças Armadas e, por outro, sobre a militarização da diplomacia. O Capítulo 6, na primeira parte, analisa esses temas, e, na segunda, aborda a questão da coordenação necessária para se amenizar algumas dessas tensões, e tentar garantir coerência dos diversos atores estatais em relação aos objetivos de política externa.

O último capítulo sintetiza, inicialmente, os principais aspectos referentes à expansão internacional e à institucionalização bilateral e multilateral da diplomacia de defesa, tanto no nível global, quanto no inter-regional, mas, principalmente, no regional, enfatizando que as interações nesse campo se dão no sentido Norte-Norte, Norte-Sul e Sul-Sul. A parte final desse capítulo retorna, basicamente, à Escola Inglesa e à sociedade internacional, para concluir sobre o poder explicativo desse conceito sob a ótica da diplomacia de defesa, considerada como uma instituição dessa sociedade. 


\section{Diplomacia como instituição}

\section{1 \\ Introdução}

A diplomacia como prática social e como uma instituição da sociedade internacional tem tido um papel de destaque na Escola Inglesa, especialmente nos trabalhos dos escritores clássicos, tais como: Wight, Bull e Watson. ${ }^{1}$ Após a Guerra Fria,o conceito de sociedade internacional ganhou maior destaque como uma contribuição para aqueles que defendem uma virada "sociológica, histórica ou normativa nas Relações Internacionais" (BELLAMY, 2005, P.2). ${ }^{2}$ Desta forma, a Escola Inglesa continua sendo importante para o entendimento da política mundial como um "fenômeno social e historicamente emergente", no qual a diplomacia desempenha um papel crucial (NEUMMAN, 2003, P.341).

Assim, como o objeto desta tese é analisar diplomacia de defesa como prática social, principalmente após a Guerra Fria, considerou-se que a Escola Inglesa tem muito a contribuir conceitualmente para o entendimento desse fenômeno, sendo complementada, sempre que necessário, com outros desenvolvimentos teóricos, já que a pesquisa de objetos de análise tão complexos como é a sociedade internacional e a diplomacia requerem uma abordagem

\footnotetext{
${ }^{1}$ Ao me referir à Escola Inglesa, não estou considerando que existe uma uniformidade de pensamento entre os autores que são usualmente com ela relacionados. Pelo contrário. Existe entre eles, muitas vezes, uma tendência a focar diferentes aspectos com visões distintas. Bull, por exemplo, já identificava duas concepções de sociedade internacional que ele denominou de "pluralista" e "solidarista", que contemplavam a tensão existente entre a ordem e a justiça nas relações internacionais. Os pluralistas defendem uma concepção fundamentada na pluralidade dos Estados com diferentes formas internas de organização na busca do Bem Comum. Já para os "solidaristas", existem padrões morais comuns que a sociedade internacional deve observar e, até mesmo, intervir, quando um Estado não os cumprirem. Além do mais, embora haja uma visão comum dos autores em relação à existência dessa sociedade, "há divergências quanto à sua constituição no passado, como ela é no presente e como deveria ser no futuro" (BELLAMY, 2005, p.12). Apesar dessa diversidade, segundo Dunne, poder-se-ia apontar algumas semelhanças que caracterizariam os autores relacionados com a Escola Inglesa: "uma identificação com uma tradição comum relacionada com o conceito de sociedade internacional; uma abordagem interpretativa e o reconhecimento da importância normativa na teoria internacional" (DUNNE, 1998). Assim sendo, o termo Escola Inglesa será usado nesta tese para facilitar a identificação teórica da abordagem não significando, no entanto, a existência de uma uniformidade de pensamento entre os autores.

${ }^{2}$ Tradução do autor. Todas as traduções que se seguem foram feitas pelo autor e para efeito de simplificação este esclarecimento não será mais explicitado no texto da tese.
} 
interdisciplinar (SMITH, HADFIELD, DUNNE, 2008, P.4) e uma metodologia pluralista (BELLAMY, 2005, P.12). Além do mais, como a diplomacia de defesa se refere, principalmente, às práticas diplomáticas no âmbito dos recursos de Defesa, a escolha dessa Escola, que privilegia o papel do Estado na condução da diplomacia, se torna ainda mais coerente para o desenvolvimento desta tese.

Desta forma, esse capítulo visa, primeiramente, descrever sucintamente a emergência na modernidade das práticas diplomáticas, como um fenômeno histórico-social, e analisar o papel da diplomacia considerada como uma instituição da sociedade internacional. Em seguida, serão analisadas a natureza das práticas diplomáticas e a cultura diplomática. Finalmente, considerando que o papel da diplomacia tem sido incrementado, tanto em amplitude quanto em profundidade, será analisada a possibilidade de existência das diplomacias paralelas (HILL, 2003; WATSON, 1982), das quais a diplomacia de defesa é um importante exemplo. Essa possibilidade enfatiza a questão da necessidade de coordenação na tentativa de busca de coerência entre os diversos agentes estatais que participam do diálogo diplomático.

\section{2}

\section{A emergência da diplomacia}

As práticas diplomáticas foram se constituindo no tempo e no espaço para a administração pacífica das relações entre as sociedades humanas. Embora alguns autores considerem que esses protótipos de diplomacia remontem tempos pretéritos, somente a partir do século XIV ela vai se consolidando na Europa como uma instituição e, no século XVII, se encontram "os ingredientes essenciais que a constituem como uma instituição internacional” (HOLSTI, 2004, P.178). ${ }^{3}$

\footnotetext{
${ }^{3}$ As práticas diplomáticas no Império Romano do Oriente e no mundo islâmico vão influenciar a instituição da diplomacia na Europa cristã durante a Idade Média e a Renascença, embora tenham sido fruto, principalmente, da adaptação às mudanças ocorridas nesses períodos. $\mathrm{Na}$ época medieval, um conjunto de normas comuns foi sendo construído e, dentre elas, aquelas que regulavam a diplomacia, fundamentadas em princípios compartilhados e nas práticas consolidadas no tempo e no espaço pelo costume. A ideia medieval de pertencimento à uma mesma civilização com valores comuns, a Cristandade latina, gerava um sentimento de que o mundo ocidental era uma única sociedade, a "república cristã" (MATTINGLY, 1955). Assim, nesse período, o direito canônico e civil muitas vezes tinha a conotação de direito internacional, o conceito de soberania encontrava-se em estágio inicial, e havia uma tênue separação entre a atividade pública e privada, fazendo com que a diplomacia medieval se desenvolvesse lentamente (HAMILTON e LANGHORNE, 1995).
} 
A partir do século $\mathrm{XV}$, as mudanças políticas foram fortalecendo a soberania estatal e desvanecendo a ordem medieval. Na Itália, dividida entre pequenos "Estados" nos quais os governantes nem sempre tinham legitimidade e viviam em constante tensão em relação às ameaças internas e externas, a busca de informações era uma atividade constante, assim como o diálogo com os governantes vizinhos para persuadir, formar alianças ou conspirar. Esses governantes usavam os mais diversos agentes disponíveis para chefiar as missões diplomáticas permanentes nos outros "Estados", que ainda não tinham o status de embaixada que mais tarde se consolidaria. Essas missões acabaram por se difundir na Europa e se mostraram mais eficientes na coleta de informações e no diálogo entre os Estados do que o sistema de enviar agentes diplomáticos quando necessário. A permanência contribuía para um melhor conhecimento do país e dos governantes, o que era extremamente útil para administrar as crescentes pressões das entidades estatais que se tornavam mais poderosas, organizadas e soberanas, e se desvanecia o poder universal da igreja (HAMILTON e LANGHORNE, 1995).

A questão religiosa teve um grande impacto na sociedade europeia. Enquanto não conseguiam unificar sua sociedade fundamentados em uma religião comum, os europeus se lançavam em um movimento de expansão além-mar que contribuiria para unificar o mundo em uma única sociedade (MATTINGLY, 1955). Assim, a diplomacia, muitas vezes amparada pelo poderio militar, desempenhou um papel importante na expansão comercial em direção ao Oriente. Os embaixadores europeus mantinham o diálogo com os governantes asiáticos e asseguravam aos líderes locais a amizade e a ajuda dos seus soberanos, inclusive a militar, em troca de permissão para efetuar o comércio. Ao mesmo tempo em que a expansão mundial se desenvolvia, os Estados da Europa construíam as bases de uma sociedade internacional fundamentada na igualdade jurídica dos seus membros e na soberania, apesar das diferenças de poder. Esse sistema se baseava em quatro principais instituições: o balanço de poder, a codificação das práticas em relação à paz e à guerra, que se tornou o Direito Internacional, o diálogo diplomático entre os Estados, levado a efeito principalmente pelo sistema de embaixadas e missões residentes nas capitais; e os congressos, nos quais se discutiam tratados relacionados com o término dos conflitos ou acordos 
relacionados com regras ou instituições, que contribuíam para a coexistência entre os Estados da "república diplomática da Europa" (WATSON, 1985, P.21-25).

Embora a coleta de informações, principalmente durante o período das guerras e da Reforma, fosse uma das principais funções dos encarregados da missão residente, no início do século XVII, quando o sistema diplomático teve um novo período de crescimento, os embaixadores passaram a substituir os enviados especiais e a ter uma maior participação na negociação entre os Estados. ${ }^{4}$ Essa mudança foi fundamental para que a prática diplomática se tornasse uma atividade contínua, o que caracterizava o reconhecimento dos Estados para a importância da instituição diplomática na condução das relações entre eles (WATSON, 1982; HAMILTON e LANGHORNE, 1995). Além do mais, diplomatas cada vez mais bem preparados se faziam necessários para discutir assuntos amplos e complexos, como exemplificado pelos congressos que resultaram nos tratados de Westphália (HOLSTI, 2004) e Utrecht, os quais exigiram agentes capazes de negociar temas relacionados com o término dos conflitos e com a futura ordem europeia ${ }^{5}$ (WATSON, 1982).

A ampliação do campo de atuação do embaixador passou a exigir, portanto, alguém com capacidades políticas e diplomáticas capaz, ainda, de “influenciar as políticas ou a atitude do governo do país anfitrião; conseguir concessões; negociar cooperação; e minimizar o atrito entre Estados...”(MATTINGLY,1955, P.240). A complexidade e a amplitude das funções diplomáticas foram constituindo uma estrutura estatal burocrática mais eficiente e eficaz. Assim, em 1626, a França se tornou pioneira na criação do primeiro ministério das Relações Exteriores. O cardeal Richelieu reconhecia a necessidade de uma estrutura interna e externa e de negociadores profissionais que pudessem administrar continuamente as relações entre os Estados europeus, visando à manutenção do equilíbrio entre eles. No século XVIII, esse tipo de ministério se tornou uma regra na Europa e começou a se espalhar lentamente para o resto do mundo (BERRIDGE, 2002). ${ }^{6}$

\footnotetext{
${ }^{4} \mathrm{O}$ chefe da missão passou a ostentar o título de embaixador, a partir do Século XVI (HAMILTON e LANGHORNE, 1995).

${ }^{5}$ Segundo Bull, o Congresso de Viena reconheceu a importância do sistema diplomático para a sociedade internacional (BULL, 1995, p.35).

${ }^{6}$ Essa tendência foi observada, inclusive, nas novas nações que se tornavam independentes das potências coloniais. Os EUA, por exemplo, em 1789, instituem o seu ministério das Relações Exteriores, denominado Departamento de Estado (BERRIDGE, 2002).
} 
Segundo Watson, a obra de François de Callières, publicada em 1716, sobre a maneira de governar com os soberanos, sintetiza o grau de institucionalização que a diplomacia havia alcançado na Europa (WATSON,1982). ${ }^{7}$ O conteúdo desse livro revela como a "diplomacia se tornara uma instituição internacional em oposição às práticas intermitentes organizadas em uma base ad hoc" (Holsti, 2004, p.179). No século XVIII, a diplomacia havia se consolidado como um "diálogo entre nações" e os Estados europeus tentavam manter a paz e a liberdade através das alianças que evitassem a hegemonia. Para tanto, ela era fundamental para coletar informações, identificar interesses comuns, negociar os acordos, etc. Essa situação da modernidade europeia foi descrita por Vattel como:

“... um sistema político no qual as Nações que habitam esta parte do mundo estão ligadas pelas suas relações e interesses, constituindo um só corpo. Ela não é mais, como nos tempos antigos, uma pilha confusa de partes isoladas, onde cada uma tinha pouca preocupação com a sorte das outras... A constante atenção dos soberanos para tudo o que se passa, o costume de ministros residentes e as negociações contínuas, fazem da Europa moderna uma espécie de República, cujos membros, independentes entre si, mas todos ligados por um interesse comum, estão unidos pela manutenção da ordem e da preservação da liberdade" (VATTEL apud TUCK, 1999, P.193).

O diálogo diplomático foi afetado pelas mudanças sociais do Século XIX, particularmente, com o desenvolvimento da tecnologia e com o crescimento do interesse e da influência da opinião pública relacionados aos temas de política externa, divulgados e potencializados pela mídia (WATSON, 1982). Nesse século, a rede diplomática continuou a se expandir, principalmente, na medida em que se intensificavam os contatos dos Estados europeus com outras comunidades independentes da Ásia, África e Américas. ${ }^{8}$

Em um contexto de comunidades políticas independentes com conflitos de interesses, o diálogo diplomático foi desenvolvendo a comunicação com uma linguagem e convenções específicas, e "a arte da persuasão, como uma alternativa ao emprego da força" (WATSON, 1982, p.84). No entanto, a diplomacia nem sempre conseguiu resolver os conflitos de interesses, e o uso da força continuou a

\footnotetext{
${ }^{7}$ Ele defendia que o embaixador deveria, também, ter a capacidade de tentar persuadir seu próprio príncipe sobre a melhor maneira de administrar assuntos pertinentes ao relacionamento entre comunidades independentes (WATSON, 1982).

${ }^{8}$ Em 1854, por exemplo, os EUA tinham 28 representações no exterior e o Brasil, em 1860, tinha uma rede diplomática que abrangia representações em 22 países (HAMILTON e LANGHORNE, 1995, p.114).
} 
ser uma opção nas relações entre os Estados. Muitas vezes, porém, ela conseguiu moderar o emprego da força e, até mesmo, negociar convenções que limitassem o seu emprego e protegessem categorias de pessoas atingidas pelos conflitos armados.

A I Guerra Mundial acabou com quase meio século de paz entre as potências europeias, sendo uma das suas causas a desintegração do Concerto da Europa, que a diplomacia não conseguira evitar (WATSON, 1982). Contudo, apesar das críticas, esta se reinventou e se tornou indispensável para as relações entre os Estados em âmbito bilateral ou multilateral (HAMILTON e LANGHORNE, 1995). O século XX presenciou o desenvolvimento da diplomacia associado à expansão do número de Estados, da interdependência e dos temas de interesse global. Essa expansão, como no passado, nunca teve um desenvolvimento linear: foi uma jornada de avanços, paradas e recuos. Apesar das dificuldades, ela foi constituindo um diálogo entre os Estados, adaptando-se às mudanças políticas, econômicas, sociais, militares, tecnológicas e ambientais de uma era em constante mudança (JACKSON, 2000), e consolidando uma sociedade internacional.

\section{3}

\section{A diplomacia e a sociedade internacional}

Como visto na seção anterior, a diplomacia se constitui pela reprodução no tempo e no espaço de determinadas práticas sociais que consubstanciam o interrelacionamento entre comunidades políticas independentes, "que desejam continuar em contato entre elas, embora mantendo suas distintas identidades" (SHARP, 2003). Ela surge da necessidade de coexistência entre essas comunidades. Segundo Watson (1982), “a condição essencial da diplomacia é, portanto, a pluralidade" e, embora se concretize, principalmente, no campo bilateral, torna-se cada vez mais multilateral, na medida em que a interdependência se expande para um maior número de países e estes dialogam

\footnotetext{
${ }^{9}$ Esse conceito de diplomacia como "administração das relações de separação entre comunidades distintas", defendido por Sharp, se assemelha ao que Hill considera a razão de ser da política externa que, segundo ele, "trata, fundamentalmente, de como grupos organizados, de distintas comunidades se inter-relacionam...” (HILL, 2003: xvii).
} 
em mecanismos multilaterais. As práticas diplomáticas têm como uma das suas funções mitigar os conflitos de interesse e incrementar a tolerância à diferença, constituindo um "diálogo entre Estados" que coexistem em uma sociedade internacional, como veremos a seguir.

\title{
2.3.1
}

\section{A diplomacia e a escola inglesa ${ }^{10}$}

É nesse contexto de relações sociais que a Escola Inglesa defende que se pode usar os conceitos de sistema de Estados e de sociedade internacional para ajudar a entender os diversos aspectos da política mundial. O primeiro, para representar uma situação do espectro na qual os elementos componentes, "sem perder sua independência, estão tão envolvidos entre eles que muitas das suas ações afetam direta ou indiretamente os demais" (BULL, 1995, P.9). O segundo, para representar uma situação na qual existe um grupo de Estados que constituem uma sociedade internacional caracterizada por interesses, valores, regras e instituições comuns que produzem ordem e estabilidade. ${ }^{11}$ De acordo com Bull:

\begin{abstract}
“...conscientes de certos interesses e valores comuns, formam uma sociedade no sentido que concebem a si próprios ligados na sua relação com os demais por um conjunto de regras comuns e compartilham o funcionamento de instituições comuns" (BULL, 1995, P.13).
\end{abstract}

Embora existam críticas a essa separação conceitual entre sociedade e sistema, o que Bull buscava era manter uma moldura mais abrangente, que abrigasse ambos os conceitos para abordar as relações internacionais, que para ele significavam uma realidade complexa no qual o sistema e a sociedade internacional podiam coexistir (LITTLE, 2005). ${ }^{12}$

\footnotetext{
${ }^{10}$ Uma abordagem de como os principais autores da Escola Inglesa trataram a diplomacia como prática social pode ser vista no artigo de Newman (2003).

${ }^{11} \mathrm{~A}$ distinção entre esses dois conceitos é melhor explicitada por Bull. No entanto, alguns críticos da Escola Inglesa afirmam que ele acaba por gerar uma tensão entre ambos, pois algumas vezes aponta a coexistência entre o sistema e a sociedade e, em outras, afirma que o sistema precede a sociedade (LITTLE, 2005).

${ }^{12}$ Bull tem uma visão teleológica e defende que essa sociedade teria determinados "objetivos": a preservação do sistema e da sociedade de Estados; a manutenção da independência ou da soberania dos seus membros; a manutenção da paz, desde que isso não implique na destruição da sociedade internacional; a limitação da violência; o cumprimento dos acordos e tratados; e a
} 
Essa sociedade foi se constituindo no tempo e no espaço, adaptando-se às transformações que caracterizaram as diversas épocas da jornada humana em direção ao século XXI. Forjou-se através das revoluções, guerras, inclusive as mundiais, descolonização e crescimento populacional. Além disso, tem promovido o diálogo entre as nações, independente de raça, cultura e ideologia e, apesar das suas imperfeições, mantém-se como:

"uma solução que provê uma base normativa e prática para administrar a política mundial, já que não existe uma alternativa melhor que não use as ideias e a linguagem a ela associadas" (JACKSON, 2000, P.420-425).

Esta tese parte da premissa da existência de uma sociedade internacional, como proposto pela Escola Inglesa. Apesar das críticas à essa abordagem, concorda com a ideia de que esse conceito é capaz de "capturar os paradoxos da vida internacional", dentre eles, uma estrutura anárquica e uma sociedade fundamentada, principalmente, na diplomacia, no direito internacional e em alguns interesses e valores comuns (FALK, 2005, P.196).

Essa dinâmica paradoxal se constitui, inclusive, no mundo pós-Guerra Fria, quando a sociedade internacional se vê fortalecida, por um lado, pela constituição de vários mecanismos de governança, ${ }^{13}$ amparados na crença de alguns valores que orientariam a forma como os Estados deveriam organizar-se internamente e conduzir-se na política internacional; e, por outro, afetada pelo uso unilateral da força por alguns países e, particularmente, pelos EUA, no contexto da "guerra ao terror", pelos movimentos extremistas e pelos conflitos intraestatais, algumas vezes envolvendo a participação de outros países.

As condições de separação dos Estados, consubstanciadas em um "sistema" ou uma "sociedade internacional", tornam a diplomacia necessária para a manutenção do diálogo e identificação dos interesses e valores comuns dos mesmos. Tais condições podem ser consideradas em um eixo no qual em uma das extremidades existe "uma completa separação e, na outra, uma completa

estabilidade da posse territorial, patrimonial, etc. Este último objetivo implicaria não só posse territorial ou patrimonial, mas o reconhecimento da esfera de jurisdição de cada Estado (BULL, 1995:16-19). Nesse trabalho não se concorda com essa visão, e se adota a abordagem de Holsti, que considera que o desenvolvimento ou a extinção de uma instituição não pode ser decorrente de um propósito pré-estabelecido (HOLSTI, 2004).

${ }^{13}$ Uma definição de governança é "a manutenção da ordem coletiva, da consecução de objetivos coletivos e de processos coletivos de regras através dos quais a ordem e os objetivos são buscados" (ROSENAU, 2000, p.175). 
integração, e é nesse espaço compreendido entre as duas extremidades que as relações de separação existem e a diplomacia se manifesta" (SHARP, 2009, P.8184).

As alternativas para a diplomacia seriam a existência de Estados independentes sem haver o diálogo diplomático entre eles, o que tornaria impossível todo o conjunto normativo existente nas diversas áreas das relações entre os mesmos: política, comercial, econômica, ambiental,militar etc.; ou a “abolição dos Estados independentes”, com a constituição de um governo ou federação mundial (WATSON, 1982).

No espaço entre essas duas alternativas, a diplomacia floresce e permanece. As relações entre os países são complexas e difíceis de serem administradas, pois existem diferentes visões do mundo, possibilidade de interpretação equivocada e o risco do uso da violência. ${ }^{14}$ Desta forma, apesar das suas imperfeições, o diálogo diplomático é indispensável para a manutenção da sociedade internacional (WATSON, 1982). Nesse contexto, a Escola Inglesa considera que a diplomacia se situaria em um ambiente internacional no qual coexistiriam em permanente tensão as três tradições do pensamento ocidental, realista, racionalista (ou internacionalista) e revolucionista (ou universalista), expostas por Wight e Bull no que concerne às relações internacionais (LITTLE, 2000); ${ }^{15}$ Holsti considera essas tradições como elementos que coexistem em maior ou menor grau na política internacional. $\mathrm{O}$ incremento na cooperação ou na governança global coexiste com padrões de comportamento "realistas" da mesma forma que a "sociedade civil internacional coexiste com a atividade política no nível nacional” (HOLSTI, 2004, P.15). É, portanto, sob essa ótica, que se pode

\footnotetext{
${ }^{14}$ Segundo Sharp, essas relações de separação são de três tipos: de encontro, de descobertas e de reencontros. As de encontro se estabelecem quando os povos se encontram pela primeira vez. As relações de descoberta são aquelas que sugerem o conhecimento mútuo das culturas de comunidades distintas, permitindo identificar similaridades e diferenças. Estas relações implicam a busca de informações e podem gerar processos de integração e de desintegração dentro da sociedade internacional, na medida em que o sentimento de diferença entre os povos aumente ou diminua. As relações de reencontro, diferente das de descoberta, atuam de forma a reafirmar as identidades atuais dos povos envolvidos. Elas permitem que aqueles que já se conhecem mantenham as suas relações, que se desdobra em um espectro que em um determinado limite pode gerar uma perfeita comunhão que anule as diferenças e, no outro, uma ampliação do grau de diferenças existentes, tornando estranho quem era de alguma forma familiar (SHARP, 2009, P. 8990).

${ }^{15}$ Bull denomina essas tradições associando-as a determinados autores: "Hobesiana, Grociana e Kantiana" (BULL, 1995, P.39). Em relação à tradição realista, ele difere de Wight, que usava Machiavel para se referir à mesma.
} 
entender porque Bull, Watson ${ }^{16} \mathrm{e}$, principalmente, Wight consideram a diplomacia uma das mais importantes instituições das relações internacionais (SHARP, 2009). ${ }^{17}$

Assim, diversos autores da chamada Escola Inglesa têm tido um interesse especial na diplomacia como um fenômeno histórico relacionado com práticas sociais específicas, considerando-a, normalmente, uma instituição da sociedade internacional (NEUMANN, 2003). ${ }^{18}$ O conceito de prática social está relacionado à uma forma de ação estabelecida socialmente que inclui um padrão de excelência, sendo fundamentais as questões da agência, do conhecimento e da capacidade de julgamento (NAVARI, 2010). ${ }^{19}$ Nesse contexto, as práticas e normas representam um papel importante na constituição da diplomacia, e é a partir de uma lógica constitutiva, segundo a tradição da Escola Inglesa, que o tema deste trabalho será abordado. Ao invés de se buscar a relação causal que explicaria por que determinadas práticas são consideradas "diplomáticas", procura-se entender as "condições necessárias e suficientes" para que elas se constituam (SEARLE, 2008, P.115) como sendo diplomáticas, ou seja: conduzidas por agentes do Estado e por meios pacíficos e relacionadas com a administração dos assuntos entre os Estados e outras entidades da política mundial etc.

Ao defender a existência da sociedade internacional e o papel da ordem na política mundial, Bull (1995) examina as interações entre os Estados e sustenta que a ordem é mantida através de interesses comuns, regras e instituições. ${ }^{20}$ Para ele, instituição "não implica, necessariamente, uma organização ou máquina administrativa, mas sim um conjunto de hábitos e práticas para a realização de

\footnotetext{
${ }^{16}$ Watson (1982) afirma que a diplomacia tem que ser entendida em um contexto no qual "um número de Estados independentes bastante envolvidos uns com os outros formam uma sociedade internacional institucionalizada ou, pelo menos, um sistema de Estados". No entanto, "apenas uma sociedade desenvolvida de Estados propicia a diplomacia com todas as suas possibilidades e limitações" (WATSON, 1982, P.12-13).

${ }^{17}$ Wight considera o sistema diplomático a instituição maior das relações internacionais e mostra como a diplomacia, considerada uma arte, foi construindo padrões específicos de interações (NEUMANN, 2003).

${ }^{18}$ Neumann (2003) oferece uma visão de como a diplomacia foi sendo tratada por diversos autores dessa Escola e, reconhecendo a sua importante contribuição, aponta para algumas possibilidades de aprimoramento do tema pela Escola Inglesa.

${ }^{19}$ As regras e os padrões são vistos sob o prisma da tradição e das instituições, considerando que as fontes dessas práticas se encontram nas experiências históricas e nas obras de determinados autores (NAVARI, 2010).

${ }^{20} \mathrm{~A}$ ordem internacional significa para Bull um padrão ou disposição da atividade internacional que sustenta os objetivos elementares, primários ou universais da sociedade internacional (BULL, 1995).
} 
objetivos comuns" (BULL, 1995, P.71). E é esse entendimento que servirá de base para a análise do tema desta tese.

A diplomacia, pela sua permanência no tempo e no espaço, é uma das instituições que contribuem para a ordem na política mundial. Bull (1995) a define como a "conduta das relações internacionais entre Estados e outras entidades que atuam na política mundial através de pessoas que são agentes oficiais e que utilizam meios pacíficos". ${ }^{21}$ Para Watson (1982), define-se como "o processo de diálogo e negociação pelo qual os Estados, em um sistema, conduzem suas relações e perseguem seus objetivos utilizando meios que não a guerra". ${ }^{22}$ É um "diálogo entre os Estados", considerados como entidades políticas que reconhecem a independência entre eles.

A diplomacia está, portanto, intimamente ligada aos Estados, embora se reconheça, também, o papel de outras entidades, tais como as organizações internacionais. ${ }^{23} \mathrm{~A}$ diplomacia se constitui, principalmente, na interação que os Estados realizam entre eles e com outras entidades que atuam na política mundial, através das práticas dos seus agentes, utilizando meios pacíficos. ${ }^{24}$ Assim, pode-se defini-la como uma instituição da sociedade internacional, que se constitui pela reprodução no tempo e no espaço de práticas sociais específicas de agentes oficiais para construir e reproduzir, por meios pacíficos, as relações entre os Estados e outras entidades que atuam na política mundial.

Com essa definição, a tese ganha sua primeira fundação. A partir dela, será construída uma definição da diplomacia de defesa como prática social. Isso, porém, não é o suficiente. O próximo passo será analisar como as instituições se constituem e se mantêm e quê critérios podem ser estabelecidos para identificálas. Esse segundo movimento permitirá estabelecer outra fundação do

${ }^{21}$ Entre esses agentes, no âmbito estatal, Bull (1995) inclui os militares e os diplomatas, ressaltando, contudo, uma distinção entre eles: os diplomatas utilizam tão somente meios pacíficos na condução das relações internacionais.

${ }^{22}$ Para Bull (1995), a diplomacia inclui tanto a formulação da política externa quanto a sua execução . Watson (1982), no entanto, considera que se deve manter a distinção entre política externa e diplomacia. Para ele, "a política externa se refere à substância das relações de um Estado com outros poderes e agências e os propósitos a serem atingidos por essas relações, e a diplomacia é o processo de diálogo e negociação entre os Estados" (WATSON, 1982, P.11). Nesta tese, será considerada a visão de Watson, considerando-se que a política externa expressa visões de mundo e objetivos a serem atingidos.

${ }^{23}$ Para Sharp (2009), o fim dos Estados soberanos não implicaria no fim da diplomacia. Watson (1982), no entanto,tem uma ideia mais restrita, ao afirmar que "o diálogo diplomático cessaria uma vez que os estados independentes deixassem de existir" (WATSON,1982, P.31).

${ }^{24} \mathrm{~A}$ diplomacia, portanto, "só é propriamente entendida no contexto de um sistema ou uma sociedade de Estados" (WATSON, 1982, P.13). 
desenvolvimento da tese, que é a idéia da diplomacia de defesa como uma instituição da sociedade internacional, explicitada no Capítulo 4.

\subsection{2}

\section{A sociedade internacional e as instituições}

As considerações anteriores e a definição de diplomacia colocam em evidência o papel das práticas sociais na constituição das instituições da sociedade internacional. Embora Bull (1985) tenha afirmado que as instituições que ele elege para o estudo da ordem na política mundial foram escolhidas, primordialmente, devido à sua permanência e, junto a Watson (1982) e outros autores da Escola Inglesa, tenha sustentado a importância daquelas práticas, se faz necessário complementar, sinteticamente, essas ideias com outras abordagens que ajudam a entender como as instituições são constituídas e mantidas.

Anthony Giddens, através da sua teoria da estruturação, defende a dualidade da estrutura como "meio e resultado da conduta que ela recursivamente organiza" (GIDDENS, 2009). ${ }^{25}$ Para ele, agente e estrutura são constituídos mutuamente por meio das práticas recorrentes. Tanto os agentes atuam sobre a sociedade, constituindo-a ou alterando-a, quanto a sociedade atua sobre a conduta dos agentes, através de padrões de interações (DOUGHERTY e PFALTZGRAFF, 2003). Assim, a estruturação das instituições depende da reprodução das condutas sociais; o que importa são as práticas sociais ordenadas no tempo e no espaço de forma recursiva. Para Giddens:

\footnotetext{
"Todos os seres humanos são agentes cognoscitivos... cuja análise da vida cotidiana é fundamental para entender a reprodução das práticas institucionalizadas... Essa reprodução das condutas sociais no espaço e no tempo geram as propriedades estruturais dos sistemas sociais e aquelas práticas que possuem uma maior extensão espaço temporal são designadas como instituições"(GIDDENS, 2009).
}

\footnotetext{
${ }^{25}$ Giddens define a estrutura como o "conjunto de regras e recursos implicados, de modo recursivo, na reprodução social” (GIDDENS, 2009, P.XXXV).
} 
Essa visão vai ao encontro da ideia de Bull (1995) de permanência das práticas como fundamental para a identificação das instituições na sociedade internacional. E o conceito de Bull (1995) sobre estas vai servir de base para K.J. Holsti (2004) estabelecer critérios para a sua identificação e seleção na sociedade internacional. Como vimos no parágrafo anterior, Bull (1995) enfatizou a importância da permanência das práticas, normas e regras, e deixou implícito o valor das idéias para identificar, além da diplomacia, as outras instituições que ele elege para o estudo da ordem na política mundial, a saber: balança de poder; grandes potências, direito internacional e guerra. É essa abordagem sobre as instituições que vai ser usada por Holsti (2004) para estudá-las em relação à mudança institucional na política internacional no pós-Guerra Fria. No entanto, da mesma forma que nesta tese, ele o faz sem aceitar os aspectos teleológicos embutidos no conceito de Bull, já que não se pode considerar que o desenvolvimento ou obsolescência das instituições seja sempre decorrente de projeto ou de propósitos comuns (HOLSTI, 2004). Assim, ele estabelece três critérios para a sua existência:

a) "um padrão de práticas ou práticas específicas rotineiras e recorrentes;

b) um conjunto coerente de ideias e/ou crenças que descrevem as necessidades para a existência de práticas comuns e apontam para os objetivos sociais que podem ser alcançados através delas; ${ }^{26}$

c) normas, incluindo regras e etiquetas, que estabelecem o que é proibido, como os atores mais importantes e os agentes devem se comportar ou agir em determinadas circunstâncias, e qual protocolo e qual etiqueta devem ser observados sob cada circunstância" (HOLSTI, 2004, P. 21).

Esses critérios atuam entre si de maneira complexa, não guardando entre eles nenhuma precedência hierárquica, nem relações causais. Por sua permanência, algumas práticas podem ganhar legitimidade e se tornar normas ou regras, ou as ideias e crenças podem moldar as práticas e transformá-las em normas; ou, ainda, um conjunto de práticas consideradas inadequadas, por diversos motivos, pode ser alterado, através da negociação, para constituir um conjunto de regras padronizadas (HOLSTI, 2004).

\footnotetext{
${ }^{26}$ As "ideias referem-se ao entendimento do que são, realmente ou hipoteticamente, um melhor "estado das coisas". São fontes poderosas de mudança e ferramentas cruciais para mobilizar a ação política ... As crenças, normalmente baseadas nas ideias, contêm a justificativa para as ideias e as prescrições normativas que postulam certas formas de comportamento (normas) e/ou mudanças do mesmo" (HOLSTI, 2004, P.21-22).
} 
Assim, Holsti (2004) identifica e seleciona quatro instituições "fundacionais" da sociedade internacional: ${ }^{27}$ Estados, territorialidade, soberania e direito internacional; e quatro de "procedimentos": diplomacia, comércio, colonialismo e guerra. As primeiras, como seu próprio nome sugere, são mais importantes que as demais, por sinalizarem que existe uma sociedade internacional, cuja organização política é distinta de outros tipos de comunidades políticas independentes existentes no passado. Elas definem os atores e seu status e "também estabelecem os princípios, normas e regras sob as quais se baseiam as relações mútuas...e conduzem a formas de ação altamente padronizadas" (HOLSTI, 2004, P.24-25). Segundo ele, as instituições de procedimento são compostas de práticas repetidas, ideias e normas, que são os alicerces que regulam as interações entre os atores. Podem desaparecer sem alterar fundamentalmente as instituições fundacionais e podem ter subcategorias. ${ }^{28}$

Eu discordo do papel secundário que Holsti atribui à diplomacia. Prefiro me alinhar com os autores da Escola Inglesa que defendem que ela é uma das mais importantes instituições da sociedade internacional. Embora não caiba nesta tese uma discussão mais aprofundada em relação à categorização desse autor, vários argumentos que sustentam a importância da diplomacia nessa sociedade estão disseminados ao longo deste capítulo. ${ }^{29}$ Além disso, as instituições fundacionais se constituem, principalmente, no processo do diálogo diplomático que possibilita a aceitação coletiva do status dessas instituições.

Apesar de discordar da categorização que Holsti (2004) estabelece para a diplomacia, sua abordagem é importante para o desenvolvimento desta tese, pois contribuirá para o entendimento da diplomacia de defesa nos seguintes aspectos: primeiro, ela corrobora a visão de Bull (1995) da diplomacia como uma instituição da sociedade internacional, mesmo considerando-a como secundária em relação às fundacionais, e reforça o papel do Estado nessa sociedade; segundo, os três critérios estabelecidos por ele serão úteis para analisar, no capítulo

\footnotetext{
${ }^{27}$ Embora Holsti (2004) afirme que elas são instituições do "sistema internacional de Westphália", ele também menciona que esse sistema seria o que Bull chama de sociedade internacional. Por coerência e simplicidade, neste texto foi adotado o termo sociedade internacional.

${ }^{28}$ Segundo Holsti (2004), o comércio e as instituições monetárias podem ser considerados como componentes da categoria mais ampla da instituição denominada "mercado".

${ }^{29} \mathrm{O}$ próprio Holsti (2004), em outra parte do seu texto, afirma que " as fundações institucionais da sociedade de estados foram construídas no final do século XVII e no início do século XVIII (soberania, igualdade legal, pacta sunt servanda, diplomacia ....). Ou seja, ele inclui a diplomacia como fundacional (HOLSTI, 2004, P.317).
} 
referente à diplomacia de defesa, se ela pode ser considerada, também, uma instituição dessa sociedade; finalmente, a sustentação de que as instituições de procedimento podem ter sub-instituições, também contribui para o argumento que será usado neste trabalho para caracterizar a relação da diplomacia de defesa com a diplomacia.

Até aqui vimos que "as instituições são práticas entranhadas no tecido da sociedade internacional" (DUNNE, 1998, P.186), que Giddens (2009) reafirma sociologicamente a importância da reprodução dessas práticas no tempo e no espaço para a estruturação das instituições sociais, e que Holsti estabelece, a partir das ideias de Bull, três critérios para identificar e selecionar as instituições da sociedade internacional. Como visto anteriormente, Holsti (2004) argumenta ainda que uma das características fundamentais das instituições fundacionais é que "elas definem privilégios e dão status a certos autores" (HOLSTI, 2004, P.25), mas ele não aprofunda em como isso se dá e qual a importância dessa dinâmica para a constituição e manutenção das instituições da sociedade internacional.

Assim, considero que a abordagem de Searle (1995, 2008) sobre as intituições sociais pode contribuir para sanar essa lacuna ${ }^{30}$ e para a análise, inclusive, da diplomacia que, embora não considerada por Holsti (2004) desta maneira, também define privilégios e dá status a certos atores. ${ }^{31}$ Para Searle (1995, 2008), as instituições sociais estão relacionadas com a capacidade que os seres humanos possuem de se envolverem em comportamentos cooperativos nos quais, para além da intencionalidade individual, existe uma intencionalidade coletiva, ${ }^{32}$ que expressa não apenas a intenção no seu sentido mais técnico, mas, também, as crenças, desejos, percepções etc. ${ }^{33}$ Essa intencionalidade atribui um

\footnotetext{
${ }^{30}$ Para Ruggie (1998), alguns conceitos de Searle, inclusive a intencionalidade coletiva, são importantes para diferenciar o construtivismo social de outras abordagens das RI.

${ }^{31}$ Existe uma discussão conceitual entre Searle (1995) e Giddens (2008), que não será tratada nesta tese, a respeito da separação entre regras constitutivas e reguladoras defendida pelo primeiro e contestada pelo segundo com o argumento que todas as regras são constitutivas. Para uma síntese desse debate e uma abordagem sobre o tema, ver Frank Hindriks, Constitutive Rules, Language, and Ontology. University of Groningen. Disponível em: http://www.rug.nl/staff/f.a.hindriks/constitutive_rules_language_ontology.pdf. Acesso em: 26 abr.2012.

${ }^{32}$ Searle $(1995,2008)$ considera que a intencionalidade coletiva tem mais poder explicativo que a noção de intersubjetividade. Onuf (2002), entretanto, critica a adoção desse conceito para explicar como as instituições se formam. Este trabalho adota o conceito de Searle.

${ }^{33}$ Segundo Searle, "a intencionalidade é a capacidade da mente pela qual os estados mentais são dirigidos para ou a respeito de objetos e situações no mundo" (SEARLE, 2008, P. 31).
} 
status específico ao fenômeno e, com o status, uma função também é atribuída. As funções de status "são veículos de poder na sociedade", pois estabelecem obrigações, direitos etc., denominados deontic powers. Essas estruturas "deônticas" são importantes porque viabilizam as razões para a ação independente do desejo, na medida em que existe o reconhecimento coletivo do status e, com ele, das relações de poder. ${ }^{34}$ As práticas humanas que carregam com elas esse reconhecimento são consideradas instituições sociais, dentre as quais se pode citar os governos, a propriedade privada, as universidades, etc. (SEARLE, 1995, 2008).

A diplomacia, no entendimento desta tese, seria, também, uma dessas instituições, na medida em que ela envolve um comportamento cooperativo e uma intencionalidade coletiva que lhe atribui uma função de status, estabelecendo obrigações, direitos, etc. (deontic powers). O reconhecimento coletivo do seu status pelos Estados e outras entidades da sociedade internacional garante o reconhecimento das obrigações, direitos etc. relacionados com as práticas e com os agentes diplomáticos, independente da vontade dos membros dessa sociedade. Assim, por exemplo, os diplomatas, os locais das embaixadas, a correspondência diplomática etc. possuem um status específico que são respeitados pela aceitação coletiva da sociedade internacional.

Existe, portanto, uma prioridade do processo sobre o produto, porque é nos processos e nos eventos que o "novo status com as correspondentes funções atribuídas ao objeto" se manifestam (SEARLE, 2008). Cada uso das práticas diplomáticas renova e fortalece a diplomacia, e demonstra a continuidade da intencionalidade coletiva na imposição de determinadas funções de status à essa instituição. $\mathrm{O}$ reconhecimento e a aceitação coletiva da mesma garante o status dos seus agentes e, consequentemente, o exercício do seu funcionamento, que evolui no tempo e no espaço.

Nesse contexto, a sociedade internacional se mantém pela intencionalidade coletiva dos seus membros, que sustenta o consenso nas instituições sociais que a constituem. Dessa forma, a abordagem de Searle contribui para fundamentar o

\footnotetext{
${ }^{34} \mathrm{O}$ autor exemplifica, mostrando que, ao aceitar a instituição da propriedade privada, a sociedade aceita os direitos e deveres relacionados com essa instituição. Assim, outros atores, independentemente do seu desejo, não podem violar os direitos de propriedade. Por outro lado, o proprietário, além dos seus direitos, tem uma série de obrigações que o levam, também, a agir independente da sua vontade (SEARLE, 2008).
} 
conceito de sociedade internacional entendida como uma construção social, conforme vislumbrado pelos autores clássicos da Escola Inglesa, defendido por outros mais recentes, e adotado neste trabalho. ${ }^{35}$

Assim, por exemplo, Dunne afirma que:

"Para a Escola Inglesa, a soberania e a não-intervenção são constitutivas da sociedade de estados: elas são sustentadas pela reprodução dessas práticas...O ato de adquirir a identidade soberana gera interesses comuns em manter o diálogo diplomático e respeitar os direitos e deveres dos outros Estados" (DUNNE, 1998, P.187-188).

Da mesma forma, Jackson defende que:

"O processo de construção do mundo social pelos seres humanos implica, também, na criação da mudança social, muitas vezes intencionalmente ou inadvertidamente, fazendo com que as instituições evoluam. Algumas delas duram muito tempo porque atendem às necessidades, circunstâncias, expectativas, comunicação e interação entre diferentes áreas das relações humanas. Elas constituem práticas ou procedimentos ou símbolos coletivamente aceitos para levar a efeito as diversas atividades sociais... A sociedade internacional é um arranjo histórico de práticas, normas e instituições periodicamente reconstituído em resposta às mudanças das ideias e das circunstâncias" (JACKSON, 2000, P. 422-423; viii).

Existe um profundo inter-relacionamento da diplomacia com as demais instituições da sociedade internacional. A diplomacia tanto afeta quanto é por elas afetada. O próprio conceito de sociedade internacional formulado por Bull aponta a importância da diplomacia para as demais instituições, e vice-versa, na medida em que ela é "o diálogo entre os Estados" que possibilita identificar os valores e interesses comuns e facilitar a constituição e a evolução das instituições comuns que são o âmago dessa sociedade. Poder-se-ia afirmar que a diplomacia é a linguagem da sociedade internacional. Ela contribui para a constituição de instituições como Estado, direito internacional etc., possibilitando o processo pelo qual se configura a aceitação coletiva da função de status relacionada com as mesmas, "que estabelece formas institucionais de poder, direitos, regras, obrigações, etc.” (SEARLE, 1995, P.70).

Assim, a diplomacia é "muito mais que a sua maquinaria (objetos sociais), e se torna uma acumulação de experiência e sabedoria que transcende a mera

\footnotetext{
${ }^{35}$ Dunne (1995) defende esse ponto de vista, sem usar os conceitos de Searle, fundamentado em textos de autores, tais como Wight, Bull, Manning e Butterfield.
} 
mecânica do diálogo" para administrar as relações na sociedade internacional (WATSON, 1982), contribuindo para a reprodução da ordem. ${ }^{36}$ Até mesmo em relação à guerra, exerce um importante papel, mantendo o que se constitui na sua principal característica, qual seja: "a ênfase na oportunidade de conversar até mesmo nas piores situações" ${ }^{37}$ (SHARP, 2009, P.198) e "de olhar para o futuro quando a vontade de submeter o outro pela força cederá maior espaço para o diálogo da persuasão" (WATSON, 1982, P.67).

Esse entendimento fica mais claro quando se visualiza a variedade das funções que a diplomacia desempenha em relação à sociedade internacional, que é o próximo tópico a ser analisado.

\subsection{3}

\section{Funções da diplomacia}

Bull (1995) considera que a diplomacia tem algumas funções: facilitar as comunicações entre os Estados, negociar acordos e tratados, minimizar o atrito nas relações internacionais, simbolizar a existência de uma sociedade de Estados e coletar informações sobre os países. Os contatos diplomáticos, normalmente, são institucionalizados, na medida em que se realizam periodicamente dentro de uma moldura de permanente relacionamento entre as partes envolvidas e são conduzidos de acordo com regras e convenções conhecidas pelas partes.

Outros autores consideram diferentes funções relacionadas à diplomacia. Barston (2006) elenca seis: cerimonial, administração, informação e comunicação, negociação internacional, serviço de proteção aos cidadãos, e contribuição para a ordem internacional. Para Hill (2003), de um modo geral, são: comunicação, negociação, participação em instituições multilaterais e promoção de bens econômicos. Já Wight considera que sejam, basicamente, a informação, a negociação, e a comunicação (NEUMANN, 2003, P.346).

A análise dessas funções não se pauta em uma visão funcionalista na qual as atividades sociais associadas com a diplomacia tenham uma necessidade

\footnotetext{
${ }^{36} \mathrm{~A}$ própria linguagem tem um papel importante no diálogo diplomático. Para uma visão desse papel como instrumento ou como meio, na prática e na teoria, ver Kurbalija e Slavick (2001) ${ }^{37}$ Para Sharp (2009), a diplomacia poderia cessar completamente apenas no caso, extremamente raro, de uma guerra de aniquilamento.
} 
funcional. Essas atividades são executadas intencionalmente e podem ter resultados não esperados (GIDDENS, 2009). A intencionalidade coletiva, que, segundo Searle $(1995,2008)$, é o componente intencional da sociedade, possibilita diferentes pessoas compartilharem, por exemplo, no fazer, no crer, no desejar e também nas atribuições de funções de status, que são desempenhadas, principalmente, em virtude dessa intencionalidade. Elas são atribuídas ou impostas por agentes conscientes e, diferente das causas, são sempre relativas aos interesses desses agentes.

Nessa visão, ao se aceitar coletivamente a regra constitutiva segundo a qual, sob certas condições, as práticas sociais para construir e reproduzir por meios pacíficos as relações entre os Estados constituem a diplomacia, também se concorda que os agentes relacionados com essa prática social tenham status, direitos, obrigações, prerrogativas, etc. Assim, se reconhece seu direito de negociar, comunicar, participar em instituições bilaterais ou multilaterais ou coletar informações ostensivas, mas não se admite, por exemplo, que esses agentes pratiquem a espionagem.

Embora se possa considerar que deveriam ser incluídas outras funções específicas, devido, por exemplo, à importância na agenda diplomática dos temas econômicos ou de instituições multilaterais, como proposto por Hill (2003), ou que deveriam ser detalhadas outras, tais como cerimonial e administração, como sugerido por Barston (2006), o argumento desta tese é que a prática diplomática depende, implícita ou explicitamente, de três funções que não são uma especificidade tão somente dessa atividade, quais sejam: reunir informações, comunicar e negociar. ${ }^{38}$ A especificidade da diplomacia se deve a duas outras importantes funções que ela exerce: a redução dos efeitos da fricção entre as entidades que atuam na política internacional e a simbolização da existência da sociedade de Estados (BULL, 1995). Considerando-se, também, que as políticas domésticas são, muitas vezes, afetadas pelo que ocorre "lá fora", o principal objeto da diplomacia é o conflito de interesses, e, portanto, ela é:

"um diálogo construtivo entre os Estados, que cria as condições para o estabelecimento de regras, códigos de conduta e instituições, contribuindo para

\footnotetext{
${ }^{38}$ Segundo Neumann (2003), Bull defende que a busca de informações necessárias para a conduta das relações internacionais na ótica da diplomacia tem suas especificidades muitas vezes relacionadas com o conhecimento das personalidades dos atores políticos, suas visões em relação aos diversos temas e as políticas de curto, médio e longo prazos do país anfitrião.
} 
resolver ou administrar os problemas de interesses conflitantes" (WATSON,1982)

Essa última função, de resolver ou amenizar os atritos, embora simbólica, pode ser evidenciada pela presença física em outros países de agentes de outros Estados que exercem a diplomacia (NEUMANN, 2003, P.348), existindo uma relação entre a qualidade e a cultura desses agentes e as funções da prática diplomática, como será visto no próximo item.

\subsection{4}

\section{Os diplomatas e a cultura diplomática}

Principalmente pela especificidade da sua condição e das funções que realizam, os diplomatas possuem uma cultura definida como "o estoque comum de ideias e valores possuídos pelos agentes estatais" (BULL, 1995, P.304). Ela é parte da cultura política internacional que, segundo Neumann (2003), Bull e Wight consideram como uma "pré-condição para a emergência da sociedade internacional”, que depende, também, da difusão de ideias e práticas. ${ }^{39}$ Para Bull (1995), a cultura diplomática é a ponte que, através do tempo, tem permitido que os Estados, apesar das suas diferenças políticas, econômicas, culturais, etc., possam constituir relações e conviver em uma "sociedade anárquica". Segundo Der Derian:

"Os Estados continuarão, diariamente, a construir e confrontar seus outros alienígenas. No entanto, através da ideia da cultura diplomática, Bull desmontou muitas das oposições fixas e das supostas eternas inimizades da política mundial, renovando uma mediação histórica entre estranhos...Nesse processo, ele revelou a função ética dessa cultura, qual seja, a sua contribuição para o surgimento de uma verdadeira sociedade internacional" (DER DERIAN, 1996, P.97).

A especificidade dos diplomatas e da sua cultura vai ser aprofundada por Sharp (2009). Fundamentado na ideia da existência das três tradições de pensamento ocidental, expostas por Wight (2001) e citadas anteriormente, ele

\footnotetext{
${ }^{39}$ Segundo O`Hagan (2005, p.213), Bull trata a cultura sob três aspectos ligeiramente distintos: cultura como diferentes padrões de comportamento, normas e valores de sociedades particulares, que podem evoluir e mesclar-se com outras culturas; cultura comum, compartilhada entre comunidades distintas; e cultura diplomática.
} 
defende a existência de uma quarta, que denomina tradição diplomática do pensamento internacional. Essa abordagem considera que a base a partir da qual os diplomatas vêm o mundo surge da ideia da co-constituição das condições e relações de separação entre entidades políticas independentes. Subjetivamente, esses diplomatas parecem um tipo particular de estrangeiros: aqueles cidadãos de outras comunidades que necessitam manter essa condição para poderem desempenhar o papel de administradores das relações de separação entre povos que, em um determinado momento no tempo e no espaço, se consideram separados, mas desejam manter relações entre eles. Essa condição de viver no espaço entre comunidades políticas independentes faz com que eles tenham uma visão de mundo distinta, em alguns momentos, até, com diferentes prioridades do governo que eles representam, e busquem manter as relações pacíficas entre povos que possuem, muitas vezes, ideias e entendimentos conflitantes. ${ }^{40}$

Assim, um diplomata, normalmente, enxerga o mundo de uma forma semelhante à dos seus colegas do próprio serviço e à dos diplomatas de outros países, o que torna possível se falar em uma comunidade diplomática, com uma cultura própria, como afirmado por Bull. Essa cultura privilegia a boa condução dos processos diplomáticos e, no tempo e no espaço, desenvolveu um elevado grau de ceticismo em relação às visões sobre o conteúdo e a substância das relações internacionais de quem não participa dessa comunidade, sem, no entanto, limitar-se à uma visão meramente técnica. Segundo Sharp, em um ambiente no qual os povos acreditam que vivem em condições de separação, os diplomatas representam nações que são instituições complexas, com múltiplas identidades, que fazem com que eles tenham que agir em diferentes contextos, de diversas formas para conduzir as relações de separação, gerando uma tradição diplomática de pensamento internacional:

\footnotetext{
"É desse espaço que os diplomatas entendem o mundo e, a partir desse entendimento, conduzem essas relações. Através das suas experiências e reflexões emerge uma tradição diplomática de pensamento internacional própria que, embora não seja contrária às tradições de pensamento descritas por Wight, não é, necessariamente, consistente com as expectativas de uma ou de outra dessas tradições" (SHARP, 2009).
}

\footnotetext{
${ }^{40}$ Para Sharp (2009), o papel da diplomacia continua mesmo em casos extremos, quando as ameaças ao uso da força se inserem no contexto, pois a premissa da tradição do pensamento diplomático é que a guerra deve ser evitada, já que, de certa forma, ela nega a própria diplomacia.
} 
Os diplomatas são agentes sujeitos às normas internacionais, com "autoridade formal e responsabilidade legal", que interagem para administrar as relações internacionais, constituindo uma comunidade diplomática (NAVARI, 2010). Tal comunidade foi se constituindo no tempo e no espaço. Durante o desenvolvimento da diplomacia na sociedade europeia, os representantes estrangeiros, embora discordassem sobre diversos temas, se conscientizaram de que tinham, também, muito em comum, como, por exemplo, defender coletivamente seus status e privilégios e trocar informações e avaliações, tornando mais coletiva a prática diplomática. Esse relacionamento foi constituindo "um corpo diplomático", no qual as relações pessoais entre seus membros muitas vezes não eram contaminadas pela inimizade entre seus governantes (WATSON, 1982, P.103). Atualmente, pode-se dizer que "existe um sistema diplomático mundial cuja força não tem precedente" (BERRIDGE, 2002, P.2-3).

O diálogo diplomático se realiza, portanto, através de agentes que precisam deter qualidades e conhecimentos específicos para a "excelência da prática diplomática, estabelecida em alguma tradição de interpretação" (NAVARI, 2010, P.611- 621). Os agentes que administram essas relações ocupam posições nas comunidades que tornam possível "um entendimento diplomático do mundo das relações humanas" e um pensar diplomaticamente em relação aos tipos de argumentos, muitas vezes conflitantes, que as pessoas defendem a respeito desse mundo e do seu papel nele (SHARP, 2009).

Essa interação, na qual o reconhecimento do "Outro", o discurso e o diálogo desmpenham um importante papel bilateral ou multilateral, é uma atividade política levada a efeito pela diplomacia, nas suas múltiplas maneiras e locais, a fim de manter a comunicação entre comunidades independentes dentro dos limites impostos pelas circunstâncias (contexto ou situação) nas quais a diplomacia opera (JACKSON, 2000). A tradição do pensamento diplomático se posiciona cautelosamente em relação às pressões para se definir claramente a balança da virtude e do que é certo ou errado em disputas nas relações internacionais. Embora a questão moral seja considerada fundamental, os diplomatas buscam entender os pontos de vista e as razões dos lados em conflito, e, desta forma, compreender como construíram as posições que defendem, a fim de alcançar a melhor solução possível para o contencioso. Para melhor 
entendimento, faz-se necessária a capacidade de se colocar na posição do outro, o que permite aos diplomatas manter uma distância dos termos através dos quais as disputas são conduzidas e evitar dicotomias do tipo certo/errado e bom/mau na cena internacional (SHARP, 2009). Assim, para a Escola Inglesa:

\begin{abstract}
“A diplomacia não é um hábito e diplomatas não praticam diplomacia como uma ação habitual....Ela é um estabelecimento de padrões, que são apenas referências sujeitas ao julgamento dos estadistas e dos agentes do Estado" (NAVARI, 2010, P.626).
\end{abstract}

Cada comunidade política independente estabelece objetivos que, normalmente, expressam valores que os governantes, algumas vezes apoiado pelos governados, gostariam de atingir (WATSON, 1982). A natureza desse processo, no qual o doméstico e o externo sempre se mesclam, variando apenas o grau dessa mistura, determina os resultados da política. ${ }^{41}$ Diferentes tipos de sociedade inserem diferentes insumos domésticos nas suas políticas externas, refletindo, muitas vezes, suas visões de mundo e as possíveis maneiras para alcançá-las (HILL, 2003). No entanto, embora essas visões frequentemente possam fazer parte do diálogo diplomático ou ser expressas, mas nem sempre perseguidas, o que os Estados fazem, normalmente, é tentar administrar, entre eles, em seu dia-a-dia, as necessidades, os conflitos e as pressões mais imediatas, que, muitas vezes, surgem como resultado das políticas e decisões internas de cada $u^{42}$ (WATSON, 1982).

Segundo a tradição da prática diplomática, deve-se ter consciência de que ocorrem mudanças em como são vistos os problemas nas relações entre

\footnotetext{
${ }^{41} \mathrm{Na}$ prática, o governo necessita tomar decisões nas mais diversas áreas, decisões essas que constituem políticas. Segundo Hilsman, este é um processo complexo, pois envolve uma gama variada de atores e dificuldades de análise e julgamento. O estabelecimento de políticas não é um processo racional de estabelecimento de objetivos e de implementação de políticas consensuais. Ele é sujeito a idas e vindas, barganhas, "forças ocultas", tentativa de harmonizar objetivos e demandas conflitantes. Há rivalidades entre as organizações governamentais, e dentro delas existem grupos que defendem interesses distintos e buscam apoio fora das suas organizações para avançar suas posições. Além do mais, existem níveis inadequados de conhecimento de problemas complexos. O resultado é que, muitas vezes, a política é a soma de um amontoado de ações desconectadas ou vagamente relacionadas ou um compromisso entre objetivos rivais, ou, até mesmo, uma mescla de meios alternativos para se tentar alcançar um objetivo. Em essência, é um processo de natureza política, onde conflito e tentativa de consenso estão presentes em um ambiente tumultuado e fluido. As mudanças políticas são concretizadas muito mais através de pequenas modificações, em um movimento tentativo de avanços e recuos e de erros e acertos nas políticas já existentes do que através de grandes decisões que inaugurariam uma nova política (HILSMAN, 1971, P.1-5).

${ }^{42}$ Quanto maior a interdependência entre os Estados, maior será o efeito das suas políticas externas sobre os demais (WATSON, 1982, P.34).
} 
comunidades políticas independentes. O que hoje é uma questão de vida ou morte ou de honra pode deixar de sê-lo no futuro (SHARP, 2009, P.296). Os objetivos dos Estados são mutáveis. Normalmente, sua preocupação primordial é assegurar a própria independência, ${ }^{43}$ o que consiste em uma "condição necessária da sociedade de Estados e um pré-requisito da diplomacia” (WATSON, 1982, P.36). No entanto, existem outros objetivos e temas conflitantes, que dependem de soluções negociadas que compatibilizem as diferentes visões. ${ }^{44}$ Assim:

“... o interesse nacional emerge das práticas das deliberações diplomáticas, da arte do que é possível e negociável internacionalmente, mais do que simplesmente de uma vontade nacional" (WATSON, 1982).

Portanto, para que sejam mantidas relações pacíficas, as diferentes visões não podem ser consideradas como algo fixo e inflexível, e:

“... ao invés da reconciliação das distintas visões, deve-se priorizar a coexistência das mesmas, não apenas no seu caráter tático de acomodação temporária, mas, também, no caráter estratégico da coexistência, desenvolvido na tradição diplomática, que considera que os principais temas gerados pelas relações de separação permanecem no tempo, já que o caráter plural dos arranjos sociais e nossas ideias sobre eles são fatores que co-determinam esses arranjos permanentemente" (SHARP, 2003, P.294 - 295).

Essa coexistência não é fácil de ser conseguida, principalmente pela diversidade dos Estados que compõem a sociedade internacional nos diversos campos das atividades humanas, especialmente no socioeconômico e militar (JACKSON, 2000). Denominações do tipo estados "desenvolvidos", “em desenvolvimento", “falidos", "fraco", "potência militar", etc. mostram como essa diversidade é percebida. ${ }^{45}$ No âmbito econômico, onde as diferenças são enormes, há organismos como o G-7 ou o G-20 e organizações internacionais como o Fundo Monetário Internacional que tentam manter algum tipo de ordem

\footnotetext{
${ }^{43}$ Segundo Watson (1982, p.35), "A mútua aceitação do princípio da independência, mesmo com exceções, é uma condição necessária para a sociedade de Estados... Isso não significa que alguns Estados ou, principalmente suas populações ou parte delas, não possam se juntar ou se separar para constituir outro Estado independente".

${ }^{44}$ Watson (1982) considera que a paz e a segurança não são pré-requisitos para a diplomacia, pois esta pode atuar ativamente durante os períodos de conflito armado.

${ }^{45}$ Embora existam diversos termos, tais como "estados fracos" e "estados falidos" para designar as diversas condições e estágios desses Estados, para efeito de simplificação, no que interessa ao tema dessa tese, será usado o termo "Estado frágil" para designar todos aqueles que, possuindo os atributos da soberania para efeitos da sociedade internacional, possuem uma "severa falta dos atributos internos da mesma" (HOLSTI, 2004, P.55).
} 
econômica. Ao mesmo tempo, os países mais ricos e algumas agências internacionais atuam, algumas vezes, para ajudar os países menos desenvolvidos, embora alguns Estados associem a ajuda internacional para conseguir mercado para os seus produtos, inclusive aqueles relacionados com a Defesa. ${ }^{46} \mathrm{O}$ chamado diálogo Norte-Sul, que vem sendo conduzido há décadas, é um sintoma dessa diversidade (WATSON, 1982). As desigualdades afetam a participação dos Estados menos desenvolvidos na interação diplomática, pois eles, normalmente, não dispõem de recursos humanos e financeiros necessários para a implementação de um sistema diplomático eficiente e eficaz. Assim, “os Estados mais poderosos, que possuem muitos recursos e uma grande variedade de instrumentos, tendem a ser os mais efetivos no processo diplomático" (HILL, 2003, P.139).

As desigualdades entre Estados levanta a questão do contestado propósito da sociedade internacional: manter a ordem, mesmo que injusta, ou prover as condições para um mundo mais justo (DUNNE, 2005). Muitos autores da Escola Inglesa não aceitam essa dicotomia e consideram essa sociedade uma instituição que se transforma no tempo, podendo, inclusive, deixar de existir no futuro, criada e organizada por seres humanos, e operada, principalmente, pelos agentes e representantes dos Estados, que interagem, tentando resolver os conflitos em temas que, na maioria das vezes, possuem um aspecto normativo (JACKSON, 2000).

Como visto anteriormente, é a atitude coletiva dos membros da sociedade internacional em relação às suas práticas, normas, regras e instituições que permite a existência da mesma. No entanto, não se pode deixar de considerar a possibilidade de destruição dessa sociedade e a necessidade de proteger e fortalecer os elementos constitutivos da mesma (LINKLATER e SUGANAMI, 2006). A consciência dos Estados em preservá-la é denominada por Watson (1982) "razão de sistema", e, assim como vários membros da Escola Inglesa, ele considera que existe uma maior responsabilidade das potências nessa

\footnotetext{
${ }^{46} \mathrm{~A}$ Grã-Bretanha, por exemplo, tem adotado, algumas vezes, a prática de associar a ajuda internacional à venda de armas. Nos anos 1990, o governo britânico foi acusado de relacionar a ajuda para construção de uma hidroelétrica na Malásia à venda de armas fabricadas no país. Mais recentemente, essa prática foi novamente denunciada na imprensa, quando autoridades governamentais britânicas demonstraram sua insatisfação em não ter conseguido vender aeronaves militares Typhonn para a Índia, apesar da ajuda que a Grã-Bretanha anualmente concede a esse país. Maiores detalhes podem ser encontrados em: www.guardian.co.uk/global-development/poverty-matters/2012/FEB/06/old-british-aid-policyrears-head. Acesso em: 22 jul.2013.
} 
preservação, porque seus comportamentos, normalmente, provocam um impacto mais significativo na sociedade internacional, já que seus interesses e ações, muitas vezes, interagem com os interesses e ações de um número mais elevado de países. ${ }^{47}$ Assim, quanto maior o poder e a riqueza de um Estado, maior a necessidade do diálogo diplomático (WATSON,1982). ${ }^{48}$ Além do papel protagônico das potências, os demais Estados também concorrem para a preservação dessa sociedade, na forma como "conciliam suas responsabilidades nacionais, internacionais e humanitárias que contribuem para a manutenção da sociedade internacional" (LINKLATER e SUGANAMI, 2006, P.233). ${ }^{49}$

A sociedade de Estados se vê muitas vezes confrontada com os conflitos intra-estatais, que ganharam uma maior atenção após a Guerra Fria, associados aos Estados frágeis, cuja capacidade para assegurar as instituições, a segurança interna e o desenvolvimento social é débil. ${ }^{50}$ Assim, a preservação da sociedade internacional vai ganhar outra dimensão, na medida em que a relação entre segurança e desenvolvimento vai ser fortalecida, embora com outros contornos, com a ideia de segurança humana proposta na Organização das Nações Unidas (ONU).

A segurança humana levantou a questão de quem seria o objeto referente que a segurança/desenvolvimento deveria priorizar (SPEAR e WILLIAMS, 2012). Ainda que o tema possibilite múltiplas visões, neste trabalho assume-se que o Estado, apesar das suas deficiências e contradições, é o referente, embora, como afirmado por Bull ( 1995), o ser humano seja mais importante do que qualquer forma de organização política que eles decidam constituir. Por enquanto,

\footnotetext{
${ }^{47} \mathrm{O}$ problema da implementação e do comportamento dos atores na prática diplomática está associado ao debate agente-estrutura. Eles, muitas vezes, possuem diferentes visões e interesses que podem dificultar ou impedir os resultados almejados. Mesmo os mais poderosos atores nem sempre conseguem moldar o ambiente da maneira que gostariam, seja por "falhas de julgamento ou por assimetrias desvantajosas relacionadas com várias dimensões, tais como informação ou legitimidade" (BRIGHI e HILL, 2008, P. 119).

${ }^{48}$ No entanto, outros "atributos" dos Estados são também significativos para avançar esse diálogo: tradição, experiência dos estadistas e diplomatas, o conceito que gozam entre os demais etc. Assim, Estados como Suíça, Canadá e Noruega têm tido, eventualmente, um papel diplomático relevante, dependendo do tema em pauta (WATSON, 1982, P. 210).

${ }^{49}$ Segundo Linklater e Suganami (2006, p.8) os conceitos de sistema, sociedade e comunidade se inserem nessa visão, fundamentados na possibilidade da mudança nas relações sociais entre comunidades políticas independentes. Assim: "os Estados que atuam para proteger, respectivamente, os objetivos sociais das relações pluralistas, solidaristas e outras inter-relações, são considerados bons cidadãos internacionais".

${ }^{50}$ Os Estados frágeis também são, normalmente, os que possuem menores recursos para a atuação diplomática (HILL, 2003, P.139).
} 
vivemos em uma sociedade internacional na qual o número de membros não para de crescer e o Estado é uma instituição que é também agente para promover o Bem Comum, garantindo a segurança e o desenvolvimento. ${ }^{51}$ Assim,“...para a maioria das pessoas, na maior parte do tempo, o seu bem estar é possível, primariamente, dentro do Estado" (HOLSTI, 2004, P.71-72).

$\mathrm{Na}$ visão da sociedade internacional, como visto anteriormente, é a atitude coletiva dos seus membros em relação às práticas, normas, regras e instituições que permite a existência da mesma. A preservação dessa sociedade depende, também, da segurança internacional que, na visão desta tese é, basicamente, a segurança dos Estados:

"a segurança internacional pode ser definida, primariamente, em termos de segurança dos Estados mais do que a segurança de outras formas de associação humana e organização. E a visão da insegurança nos Estados considerados falidos, mostra que, na falta de alternativas, nós continuamos a ser habitantes de uma sociedade internacional de Estados" (HOLSTI, 2004, P. 54-68).

Nesse contexto, o diálogo diplomático pode ser, algumas vezes, complicado de tal maneira por forças políticas, econômicas, sociais, culturais, militares ou ambientais que resultem no emprego da força. Diplomacia e guerra não se encontram em extremos. Elas estão intimamente ligadas, embora possuam importantes diferenças práticas e éticas. A guerra é, também, uma instituição da sociedade internacional (BULL, 1995; HOLSTI, 2004). ${ }^{52}$ Apesar de o uso da força poder ser considerado uma forma extrema de persuasão, a diplomacia, concebida como a arte da persuasão, desde o início se constituiu como uma instituição que tenta evitar este uso para administrar as visões conflituosas dos sistemas de Estado a ou da sociedade internacional (WATSON, 1982). No entanto, "temperado pela prudência e limitado por regras", o emprego da força se torna uma possibilidade muitas vezes efetiva, apesar dos riscos e dos custos materiais e humanos, e a guerra exerce um reconhecido papel na lógica do sistema internacional como um recurso extremo da política dos Estados que:

\footnotetext{
${ }^{51}$ Os Estados, apesar dos problemas a eles relacionados, continuam a crescer em número, sendo que os 45 membros iniciais da ONU, em 1945, passaram a ser 193, em 2011. Disponível em: http://www.un.org/en/members/growth.shtml. Acesso em: 14 mai.2013.

${ }^{52}$ Apesar do declínio da guerra em várias partes do mundo, "o uso da força armada e da violência continua sendo uma proeminente característica do sistema internacional contemporâneo" (HOLSTI, 2004, P.298).
} 
"apesar das suas óbvias desvantagens, é tolerada sob certas circunstâncias, embora não aprovada pela sociedade internacional, que tenta regulá-la e limitar seus danos ao tecido da sociedade internacional e dos Estados envolvidos" (WATSON, 1982, P.57-58).

Segundo Sharp, as relações entre os Estados dependerão do diálogo diplomático, enquanto houver comunidades políticas independentes que queiram manter as condições de separação, sem que sejam cortados os laços entre elas. Assim, apesar dos movimentos dos atores da sociedade civil, das organizações internacionais e dos efeitos da globalização que já transformaram a soberania formal dos mesmos, a sociedade de Estados continua poderosa e independente. Apesar dos fracassos da diplomacia e, mesmo que se conclua que as relações internacionais independem dela, a condição social dessas relações recria as práticas diplomáticas e a própria diplomacia, gerando as sociedades internacionais que permitem que elas sejam, assim, mais estáveis e pacíficas do que seriam de outro modo (SHARP, 2009). Mesmo sofrendo, ao longo do tempo, desafios e afirmações sobre o seu declínio, a diplomacia profissional continua sendo uma importante instituição da sociedade internacional, não apenas no que concerne à questão da ordem.

O fim da Guerra Fria incrementou a discussão sobre a mudança na política mundial. Em relação à diplomacia, embora "as suas funções essenciais tenham permanecido inalteradas" (HOLSTI, 2004, P.15), ela tem sofrido alterações atinentes ao incremento da sua complexidade, principalmente, no que concerne à amplitude, profundidade e especialização dos temas tratados, número de agentes e tarefas, etc. Esse fenômeno tem contribuído para que outros setores do governo e, inclusive, do legislativo e do judiciário engajem diretamente com seus equivalentes de outros Estados, gerando a preocupação com a possibilidade de "diplomacias paralelas" que poderiam dificultar ainda mais a coordenação dos ministério das Relações Exteriores na busca de coerência na cena internacional (HILL, 2003). 


\section{4}

\section{A descentralização da diplomacia e as diplomacias setoriais}

A administração das relações entre Estados e outras entidades da política internacional vem se tornando muito mais complexa e isso se deve, principalmente, à duas tendências de longo prazo, que atuam conjuntamente, afetando-se mutuamente e incrementando o papel da diplomacia: o crescimento do poder do Estado no âmbito doméstico e da interdependência no âmbito mundial (WATSON, 1982), que foi intensificada com o fim do conflito ideológico que permeou a Guerra Fria (HERZ e HOFFMAN, 2004).

Os Estados têm se tornado multifuncionais, expandindo seu raio de ação internamente, atuando em diversas áreas, tais como saúde, trabalho, comunicação, cultura, comércio etc. (HOLSTI, 2004). Essa expansão, devido à interdependência, tem gerado agências internacionais, algumas de caráter quase universal e outras de caráter regional, e um aumento no diálogo bilateral e multilateral no que concerne às negociações relacionadas com tratados, acordos, criação de organismos internacionais etc. Tal expansão se dá, inclusive, na economia, onde até mesmo os países ocidentais liberais mais desenvolvidos consideram como uma das suas principais tarefas a eficiente administração econômica, que impacta na vida da população e é, também, um dos principais fatores para o sucesso na disputa política doméstica. Normalmente, em face, ainda, da interdependência, tanto os governos que defendem uma posição mais estatizante quanto aqueles que defendem uma posição mais liberal, afetam e são afetados pela decisão dos demais Estados, e estão sujeitos aos altos e baixos da situação econômica internacional, como visto nas crises financeiras mundiais das últimas décadas (WATSON, 1982).

Assim, o avanço do poder doméstico dos Estados em outros campos das atividades humanas e a interdependência entre eles e entre esses campos afetam a diplomacia e incrementam seu papel no diálogo entre entidades da sociedade internacional, ajudando a criar normas, regras e instituições que permitem a coexistência entre elas, mas que, por outro lado, dificultam o papel dos ministério das Relações Exteriores ${ }^{53}$ (WATSON, 1982; SIMPSON, 1982; HILL, 2003).

\footnotetext{
${ }^{53} \mathrm{~A}$ instituição diplomática expandiu seu número de agentes e tarefas e o escopo das suas atividades, inclusive com normas e regras mais complexas. No entanto, ela manteve suas funções
} 
Como afirmado por Holsti:

"Hoje, o escopo da diplomacia abrange toda a gama de problemas gerados pelas sociedades modernas, incluindo, por exemplo, meio-ambiente, comércio, investimento, ajuda externa, relações culturais, temas de segurança, controle de armamento, direitos humanos, aviação, recursos naturais, saúde, crime internacional, imigração ilegal etc." (HOLSTI, 2004, P.192).

As duas tendências acima mencionadas, que conduzem à essa imensa ampliação do escopo da diplomacia, complicam o processo de formulação e implementação dos objetivos estatais relacionados com as relações internacionais, na medida em que a dispersão e a especificidade de determinados temas que exigem um conhecimento especializado dificultam a administração das relações diplomáticas por uma única instituição estatal, que muitas vezes sofre, também, a falta de recursos humanos e financeiros e de apoio político doméstico (HILSMAN, 1973; HILL, 2003).

O reconhecimento do vetor dispersivo e especializado tem gerado tensões no processo estatal de condução do diálogo diplomático, levando à busca de adaptação no órgão responsável pela diplomacia, seja criando departamentos especializados e preparando melhor seus recursos humanos, seja aceitando a participação nas embaixadas de adidos oriundos de outras agências governamentais ou incorporando no processo especialistas provenientes de vários segmentos da sociedade para ajudarem no estabelecimento das posições a serem defendidas no cenário internacional.

Mesmo assim, a complexidade que a diplomacia alcançou, tanto em amplitude, quanto em profundidade, aliado ao crescente número de atores com interesses nem sempre convergentes são alguns fatores que dificultam a tarefa de centralização e coordenação que os ministério das Relações Exteriores tentam efetuar na busca de coerência na atuação internacional. Desta forma, a ideia do Estado como um ator unitário, com interesses nacionais auto-evidentes e imutáveis, não se sustenta, apesar das tentativas de coordenação que os órgãos diplomáticos buscam estabelecer, relacionadas com a atividade política em termos de ações, declarações e valores, através dos quais os atores tentam avançar seus 
interesses ou moldar o mundo (HILL, 2003), no contexto de interesses conflitantes entre os Estados.

E quais seriam os principais atores que participam desse processo interagindo internacionalmente? Cabe aos chefes de governo a responsabilidade pela negociação e pelo diálogo com os Estados. Entretanto, devido à amplitude e complexidade desse processo, eles se vêm obrigados a delegar grande parte da condução e das decisões menos importantes a outros setores governamentais. Segundo Hilsman (1971), os que participam desse processo podem ser representados em forma de três círculos concêntricos que, algumas vezes, diferem em termos de número e de agentes neles contidos. No primeiro, estaria o Chefe de Governo e aqueles que decidem no mais alto nível governamental, cujo principal representante seria o secretário ou o ministro que trata das Relações Exteriores. O segundo círculo contaria com outros ministérios, departamentos e agências do Executivo. E o terceiro envolveria a mídia, o Congresso, os grupos de interesse, a Academia e o público interessado.

Assim, cabe aos ministério das Relações Exteriores ou seus congêneres a primazia na condução do processo diplomático, tendo, no entanto, que conviver, muitas vezes, com as possibilidades de diplomacias setoriais conduzidas pelos outros órgãos governamentais que atuam na cena internacional (HILSMAN, 1971; SIMPSON, 1980; WATSON, 1982; HILL, 2003). Como acima descrito, a dimensão e a profundidade dos temas que fazem parte do diálogo diplomático contribuem para que outros atores estatais mantenham contatos diretos com seus correspondentes em outros países ou com outras entidades que atuam na política mundial, que são facilitados pela variedade de instrumentos disponibilizados pela revolução nas comunicações.

Como afirmado por Hill, esses atores nem sempre têm uma unidade de propósito, nem atuam racionalmente, e a agência tem que ser entendida no contexto das capacidades e instrumentos à disposição dos formuladores das políticas e das limitações para o seu uso, considerando a implementação como uma dimensão importante de agir diplomaticamente. Portanto, a coerência é uma decorrência da necessidade de coordenação das diplomacias setoriais, de modo a tentar integrar as ações e decisões que um Estado procura implementar no seu relacionamento com os demais e com outras entidades da política mundial (HILL, 
2003). ${ }^{54}$ Os ministérios das Relações Exteriores buscam, assim, coordenar as ações ou pelo menos manter um nível de comunicação e cooperação entre os diversos atores estatais, de modo a buscar algum tipo de coerência na defesa dos objetivos que o Estado gostaria de alcançar (PIGMAN, 2010).

Dentre as diplomacias setoriais realizadas pelos demais órgãos estatais, aquela realizada no âmbito dos ministérios da Defesa possui um papel relevante (HILSMAN, 1971; SIMPSON, 1980; HILL, 2003; PRIEST, 2004; STEVENSON, 2007; REVERON, 2010). ${ }^{55}$ Essa diplomacia tem sido denominada diplomacia de defesa ou diplomacia militar (DAVIS, 1996; UK, 1998; DU PLESSIS, 2008; LIHUA, 2011). Para alguns autores, o ministério da Defesa e o ministério das Relações Exteriores são aliados na condução da diplomacia, sendo que a influência do primeiro cresce nos momentos de crise ou conflito armado (HILSMAN, 1971), ou quando a agenda de segurança e defesa ganha prioridade. Para outros, eles são potenciais rivais, pois, embora possam ser aliados, os ministérios da Defesa têm sob sua subordinação as Forças Armadas, que possuem seus próprios interesses e contatos diretos com as congêneres de outros países, fazendo com que, muitas vezes intencionalmente, possam conformar parte de uma política externa paralela que não esteja de acordo com o pensamento oficial dos ministério das Relações Exteriores (HILL, 2003).

\section{5 \\ Conclusão}

Os Estados foram constituindo, no tempo e no espaço, práticas diplomáticas que, embora pudessem ter formas distintas, "possuíam o mesmo propósito: conduzir o diálogo entre eles" (WATSON, 1982, P.83) em uma

\footnotetext{
${ }^{54}$ Segundo Hill (2003), essas ações, idealmente, deveriam ser orientadas por uma estratégia de caráter genérico que apontaria para os objetivos a serem alcançados, os meios a serem usados e os valores que a sociedade considera importante projetar externamente.

${ }^{55}$ Diversos exemplos nos EUA mostram que o Departamento de Estado (DE) busca, muitas vezes, desempenhar um papel em assuntos militares ou estratégicos e, por outro lado, aqueles com responsabilidades na Defesa buscam influenciar em determinados temas de política externa. Nesses casos, a supervisão presidencial se faz mais necessária. No entanto, o setor responsável pela política externa deve ser o líder e defensor dessa política e o coordenador-chefe quando os temas de política externa envolvem outros ministérios, devido à primazia da Política sobre considerações de caráter econômico, militar, social ou ambiental (HILSMAN, 1971).
} 
sociedade internacional, entendida como uma construção social. As condições de separação entre os Estados se concretizaram em diferentes épocas e condições, tornando mais fácil ou mais difícil o diálogo conduzido pela diplomacia (SHARP, 2009), considerada nesta tese como uma instituição da sociedade internacional que se constitui pela reprodução no tempo e no espaço de práticas sociais específicas de agentes oficiais para construir e reproduzir por meios pacíficos as relações entre os Estados e outras entidades que atuam na política mundial.

O conceito de sociedade internacional, na qual coexistem elementos de conflito e cooperação, de anarquia e de alguns interesses, valores e instituições comuns, possibilita analisar aspectos paradoxais da convivência internacional, inclusive o entendimento desta tese, que argumenta a existência de uma diplomacia não coercitiva relacionada com os instrumentos de força, que tem sido incrementada, principalmente, após a Guerra Fria. Assim, embora a maioria dos autores da Escola Inglesa e os demais analisados neste capítulo tenham, praticamente, tratado apenas do aspecto coercitivo dos recursos de defesa, a discussão conceitual acima empreendida fornecerá os elementos que permitirão o desenvolvimento de uma abordagem sobre o conjunto de práticas sociais não coercitivas relacionadas com o âmbito da Defesa na sociedade internacional.

No entanto, antes de se passar para a discussão conceitual sobre a diplomacia de defesa, é preciso entender quais são alguns dos principais tipos de práticas sociais que a constituem e qual o seu grau de institucionalização, que lhes asseguram um papel importante na sociedade internacional, como defendido nesta tese. Esse é o tema do próximo capítulo. 


\section{A institucionalização e a internacionalização da diplomacia de defesa}

\section{1}

\section{Introdução}

Como visto no capítulo anterior, a diplomacia se constitui e institucionaliza pelas práticas sociais, crenças e normas que são reproduzidas, no tempo e no espaço, pelos agentes oficiais dos Estados e de outras entidades que atuam na política internacional.

Esse processo também se desenvolve no campo da segurança e da defesa, envolvendo os ministérios da Defesa e as Forças Armadas em um conjunto de práticas bilaterais e multilaterais comumente denominado diplomacia de defesa ou diplomacia militar. ${ }^{56}$ Embora envolva a maioria dos membros da sociedade internacional, ela possui, da mesma forma que a diplomacia, diferentes escalas de atuação, dependendo dos países, da região e dos recursos tangíveis e intangíveis relacionados com a Defesa que um determinado país ou organização dispõe. Normalmente, as potências militares participam com maior abrangência e têm uma atuação mais destacada nesse campo. Os EUA, a maior delas, com alcance mundial, são considerados aqueles que têm o papel mais relevante nesse tipo de diplomacia (COTTEY e FOSTER, 2004, P.75).

Esse capítulo visa mostrar, resumidamente, a diversidade, amplitude, institucionalização e internacionalização dessas práticas sociais, sem a pretensão de fazer um inventário exaustivo da sua disseminação entre os Estados e outras entidades que interagem na política internacional, o que seria uma tarefa que fugiria ao propósito desta tese.

\footnotetext{
56 Os termos "diplomacia de defesa" e "diplomacia militar" poderão ser encontrados indistintamente, pois os documentos e artigos sobre essa atividade, normalmente, usam os dois indistintamente para representar o mesmo fenômeno. No entanto, o argumento da tese é que o termo "diplomacia de defesa" o define melhor, como será discutido adiante e, portanto, buscar-se-á privilegiar o seu emprego neste trabalho.
} 


\section{2}

\section{Institucionalização e internacionalização}

A disseminação da diplomacia de defesa entre os Estados torna difícil uma compilação de como cada membro da sociedade internacional a conduz e dos mecanismos constituídos nesse campo. ${ }^{57}$ No entanto, de um modo geral, as principais práticas à ela relacionadas são: contatos bilaterais e multilaterais de alto nível; apoio para a cooperação militar regional; apoio para reforma do setor de segurança; apoio para o desenvolvimento de capacidades para atuar em forças de paz; designação de adidos; acordos bilaterais de defesa; treinamento de pessoal militar e civil; promoção do controle democrático das Forças Armadas; visitas e contatos de pessoal e unidades; designação de militares e civis para servirem em organizações militares de outros países; apoio em fornecimento de equipamento e outros materiais de aplicação militar; e exercícios militares bilaterais e multilaterais (COTTEY e FOSTER, 2004, P.7).

No caso dos EUA, as atividades da diplomacia de defesa concentrar-seiam em cinco categorias: contatos de alto-nível, contatos entre Estados-Maiores, compartilhamento de conhecimentos profissionais, desenvolvimento do conhecimento de funcionários civis ligados à defesa sobre temas de defesa, apoio ao treinamento, ensino e pesquisa sobre temas relacionados com a Defesa (COPE, 1996), e o outro componente, as interações militares, que incluem os programas de cooperação sustentados com fundos do Departamento de Defesa e de Estado. ${ }^{58}$

Essas atividades, no entanto, tornam-se mais abrangentes quando se considera a assistência de segurança que os EUA têm desenvolvido em várias regiões do mundo, que também inclui, entre outras, a assistência humanitária, a contribuição para a construção da infraestrutura logística, o apoio em casos de desastres naturais, a cooperação para treinamento e equipagem para operações de paz ou para o monitoramento e controle das fronteiras aéreas, terrestres e marítimas, os exercícios militares, o treinamento e a assessoria para ajudar na boa

\footnotetext{
${ }^{57}$ Para uma visão parcial dessa atividade, ver Muthanna (2006). O autor faz uma descrição da cooperação no âmbito da Defesa, por alguns países e regiões, com o propósito de oferecer opções nesse campo para a Índia.

${ }_{58}$ Os programas de financiamento e vendas militares e de treinamento e educação militar internacional, embora orientados e fiscalizados pelo Departamento de Estado, são conduzidos pelo Departamento de Defesa, através da Agência de Cooperação de Defesa e Segurança. Disponível em: http://fpc.state.gov/documents/organization/110406.pdf. Acesso em: 23 nov.2013.
} 
governança e na resolução de conflitos locais. Os EUA têm militares em mais de 150 países, participando em atividades de "assistência de segurança", avançando em setores que eram, normalmente, de domínio civil, como veremos no capítulo referente às tensões da diplomacia de defesa (REVERON, 2010). ${ }^{59}$

$\mathrm{Na}$ Grã-Bretanha, o escopo da diplomacia de defesa inclui o controle de armas; a não-proliferação e outras medidas relacionadas com a construção da confiança e da segurança; as atividades de assistência e cooperação bilateral para contribuir para a segurança e a estabilidade da Ásia Central, Europa Central e Oriental, principalmente a Rússia; e, finalmente, os programas de apoio ao treinamento militar de outros países. Nas regiões citadas, a diplomacia de defesa também busca contribuir para a reforma dos sistemas de defesa (UK, 1998).

$\mathrm{Na}$ visão do Reino Unido, essa diplomacia incorpora, ainda, tarefas, tais como: o trabalho dos adidos; os cursos e treinamentos; exercícios militares; visitas de ministros e de pessoal de outros níveis; visitas de unidades militares; intercâmbio de pessoal; seminários; e reuniões de Estados-Maiores. No âmbito do controle de armamento e não-proliferação, além de outras tarefas, o Ministério da Defesa ficou responsável pelos recursos para o fundo de desmilitarização química e pelos programas de não proliferação biológica na Rússia (UK, 1998).

A Estratégia Internacional de Engajamento de Defesa e de Relações Exteriores, de 2013, define, também, algumas das principais práticas da diplomacia de defesa: as visitas entre agentes relacionados com a Defesa; a rede de adidos militares; os tratados e acordos internacionais; as alianças e as parcerias estratégicas; a assessoria civil de Defesa; o treinamento no país e no exterior; o trabalho com as organizações multilaterais, incluindo a Organização do Tratado do Atlântico Norte (OTAN), a União Europeia (EU) e a ONU; as visitas de unidades militares; e o intercâmbio de pessoal (UK, 2013, p. 1-4).

Na China, desde os anos 1950, com a criação de um escritório de assuntos internacionais no Ministério de Defesa Nacional, essa diplomacia se desenvolveu, e em 2011:

\footnotetext{
${ }^{59}$ Os EUA tinham, em 2013, adidos navais em 78 países. Desse total, 20 eram Senior Defence Official/ Defence Attaché (SDO/DATT). Os militares que ocupam essa posição são os assessores do embaixador para assuntos militares e representam o Secretário de Defesa e o Chefe da Junta de Estados-Maiores junto ao Ministério da Defesa do país no qual estão acreditados. Disponível em:http://www.public.navy.mil/bupersnpc/officer/Detailing/attache/Documents/Attache\%20Brief\%20JAN\%2013.pdf. Acesso em: 06 set. 2013.
} 
"mantinha contatos militares com mais de 150 países, possuía mecanismos de consulta de defesa e segurança em 22 nações, tinha 102 adidos militares de outros países e organizava cerca de 100 delegações de visitas por ano, consolidando um padrão abrangente de várias camadas de interação no âmbito militar" (LIHUA, 2011).

Além dessas práticas, o país participa de mecanismos multilaterais de Defesa, de forças de paz, de programas de intercâmbio e de cursos militares no exterior, de exercícios e operações militares, venda e transferência de equipamentos, e programas de assistência para outros Estados (MUTHANNA, 2006, P.51). ${ }^{60}$

Os países considerados emergentes, apenas para citar outros exemplos, também participam dessa dinâmica de internacionalização e institucionalização da diplomacia de defesa, que na África do Sul, engloba atividades, tais como: a rede de adidos, a interação de defesa bi e multilateral, as visitas de comitivas, treinamento e ensino, transferência de equipamentos, e reconstrução pós-conflito. Em 2008, os setores subordinados ao Departamento de Defesa realizaram 642 visitas ao exterior e receberam 111 visitas de outros países (DU PLESSIS, 2008, P.104-108). Entre 2012 e 2013, existiam no país adidos de defesa ou assessores de 48 nações, enquanto a África do Sul mantinha adidos de defesa residentes em 40 países e organizações, e não-residentes em outras 21 (A. SUL, 2013, P.100-101). A Índia tem produzido e reproduzido as práticas sociais relacionadas com a diplomacia de defesa desde a sua independência, e, na última década, tem incrementado a sua atuação. Em 2011, mantinha relacionamento de defesa com mais de 50 países (MUTHANNA, 2011). O Brasil, em 2012, possuía 64 adidos militares no Exterior e 39 representantes em organizações internacionais (BRASIL, 2012, P.239).

As ações da diplomacia de defesa se ampliaram para áreas como a saúde, aproveitando os recursos humanos e materiais do setor de Defesa. Alguns países possuem nas suas marinhas navios-hospitais que, normalmente, seriam usados no contexto do conflito interestatal, mas que, durante os períodos de paz, são recursos empregados na diplomacia, contribuindo para uma melhor imagem internacional do país a que pertencem. Os EUA possuem dois navios hospitais, o

${ }^{60}$ Para uma visão oficial da importância que a China dá a esse tipo de diplomacia e seu desenvolvimento com países ao redor do mundo, ver o texto "New Era for China's Military Diplomacy" . Disponível em: http://www.chinaembassy.bg/eng/dtxw/t131779.htm. Acesso em: 15 jan. 2014. 
USNS Comfort e o USNS Mercy, que fazem regularmente operações em diversos países para tratar a população ou atender a desastres humanitários. Uma das operações, denominada "Promessa Contínua", é descrita em documentos oficiais da marinha norte-americana como "uma contribuição ao esforço do Comando Militar Sul dos EUA para mostrar o compromisso desse país com o hemisfério ocidental." 61

O então Secretário de Defesa dos EUA, Robert M.Gates, assim se referiu em relação à atuação do USNS Comfort em uma das suas operações:

"Indiscutivelmente, um dos atos mais bem-sucedidos de diplomacia pública norte-americana até agora, neste novo século, foi a turnê do USNS Comfort em 2007. Este navio, levando uma equipe médica diversificada e dedicada, visitou 12 países, realizou cerca de 400.000 consultas a pacientes, cerca de 1.700 cirurgias e mais de 32.000 imunizações, além de treinar 28 mil estudantes de medicina e técnicos. O sucesso dessa primeira turnê impulsionou as subsequentes missões "Promessa Contínua" (GATES, 2009). ${ }^{62}$

Essa prática da diplomacia de defesa já foi incorporada, também, pela China. O navio-hospital "Ark Peace" da marinha chinesa, na sua viagem inaugural, visitou o Caribe, em 2011, em uma missão de serviço médico em Cuba, Jamaica, Trinidad e Tobago e Costa Rica. A ação, intitulada "Missão de Harmonia 2011", foi a primeira operação desse tipo na região do Caribe, visando "aprofundar as relações amistosas entre a China e os quatros países caribenhos, e fornecer serviço médico humanitário." 63

Muitas das práticas relacionadas com a diplomacia de defesa estão institucionalizadas, na medida em que se realizam periodicamente, sob a moldura do relacionamento permanente entre os Estados, e são conduzidas em conformidade com regras e convenções aceitas pelas partes envolvidas. Aquelas relacionadas com os mecanismos e os acordos são de caráter bilateral ou multilateral. Os multilaterais, geralmente, são estabelecidos no âmbito regional, outros, estão associados a tratados ou alianças, como veremos a seguir.

\footnotetext{
${ }^{61}$ Essa frase está estampada na carta de boas-vindas do comandante da missão de 2013. Outros detalhes podem ser em: http://www.med.navy.mil/sites/usnscomfort/Documents/WELCOMEABOARD_CONTINUING\% 20PROMISE\%2013\%20FINAL\%20V2.pdf. Acesso em: 20 Jun.2013.

${ }^{62} \mathrm{O}$ discurso completo está disponível em: http://www.defense.gov/speeches/speech.aspx?speechid=1363. Acesso em: 20 jul.2013. 63 Alguns detalhes da operação podem ser vistos em: http://www.chinadaily.com.cn/usa/china/2011-10/15/content_13906847_3.htm; http://portuguese.cri.cn/561/2011/09/16/1s140170.htm. Acesso em: 20 Jun.2013.
} 


\subsection{1}

\section{Mecanismos bilaterais e multilaterais}

Os mecanismos da diplomacia de defesa são comumente caracterizados por um conjunto de ideias e crenças, que sustentam as práticas sociais e as normas que os constituem, e por uma institucionalização burocrática, que garante a organização e a estrutura necessárias para o seu funcionamento no tempo e no espaço. Eles provêm as condições para as interações no âmbito da Defesa entre os Estados e outras entidades que atuam na política internacional.

A interdependência e os interesses comuns são fatores que contribuem para o desenvolvimento desses mecanismos. Tanto bilateral quanto multilateralmente, muitos deles se constituem foros de discussão e instâncias de cooperação por onde fluem ideias e informações e onde conflitos de interesses podem, muitas vezes, ser acomodados, concessões incorporadas e compromissos assumidos. Os multilaterais se constituem, ainda, um fator de incremento das interações bilaterais.

Essas interações podem ser constituídas em diversos níveis e práticas. Muitas vezes, são decorrência do desenvolvimento de arranjos ou cooperação conformados pelo diálogo diplomático de caráter político de mais alto-nível. Elas podem ser, também, resultado de "parcerias estratégicas" ou de decisão explícita dos Chefes de Estado ou de Governo, quando da constituição de mecanismos políticos. Outras vezes, são originadas no âmbito dos ministérios da Defesa e das Forças Armadas ou, mesmo, envolver apenas uma ou mais destas Forças. A sua abrangência também varia, podendo ser composta de um maior ou menor conjunto de práticas sociais citadas no item anterior.

Muitos mecanismos políticos estabelecem os setores e níveis decisórios, nos quais o conselho de Chefes de Estado é a instância máxima. Abaixo dessa instância estão as reuniões ou conselho de ministros das Relações Exteriores, que promovem o diálogo político, preparam as reuniões dos Chefes de Estado, e implementam as decisões por eles tomadas. Normalmente, existem reuniões prévias, com representantes de outros níveis daqueles ministérios, para a discussão e coordenação dos temas e propostas a serem sugeridas para os escalões acima citados. Finalmente, existem as instâncias setoriais, nas quais se incluem as relativas à diplomacia de defesa, que, geralmente, se desenvolvem em diversos 
níveis, sendo que aqueles que envolvem os ministros da Defesa estão enquadrados entre os de mais alto nível desse tipo de diplomacia. Para dar uma ideia da amplitude da disseminação desses mecanismos na sociedade internacional, veremos a seguir alguns exemplos da institucionalização dessas práticas sociais.

É comum a institucionalização das relações no âmbito da Defesa entre dois Estados, que ocorre em consequência às inúmeras práticas mencionadas no item anterior, podendo conformar um acordo formal nessa área. Um país como o Brasil, por exemplo, que apesar de ter um setor de Defesa muito além dos países mais desenvolvidos pode ser considerado uma potência regional, possuía, em 2010 "um total de 28 acordos de cooperação em Defesa e 29 acordos e protocolos bilaterais em diversos domínios da cooperação militar" (BRASIL, 2010). ${ }^{64}$ Embora o acordo formal seja uma decorrência lógica da interação entre os Estados, ele não é um requisito que impeça as relações nesse campo. No caso do Brasil e dos EUA, por exemplo, a não existência de um acordo militar desde 1977 não impediu intensas interações entre os dois países, inclusive com a manutenção de antigos mecanismos entre suas Forças Armadas.

Os mecanismos bilaterais podem ser constituídos, também, entre organizações internacionais ou entre elas e outros Estados. É o caso, por exemplo, da cooperação entre a OTAN e determinados países, que tem como um dos seus precursores o programa Parceria para a Paz, criado em 1994, após o fim do conflito ideológico. O documento que estabelecia a sua constituição se baseava na crença de que a estabilidade e a segurança na área euroatlântica só poderiam ser alcançadas através da cooperação e atuação mútua, que, inclusive, promovessem liberdade, paz, democracia, justiça e os direitos humanos, além de respeito ao direito internacional. Alguns dos objetivos desse programa são: o controle civil das Forças Armadas, a transparência do setor de defesa e a busca pela interoperabilidade, que permitisse ao parceiro operar junto com as forças militares da OTAN.

A Parceria para a Paz oferecia um amplo leque de atividades passíveis de cooperação, que deveria ser custeado com recursos dos próprios países participantes, dentre os quais: política e reforma do setor de defesa; relações civis-

${ }^{64}$ Em 2010, segundo o Ministério das Relações Exteriores do Brasil, a maioria desses instrumentos já estava em vigor. Disponível em: http://www.itamaraty.gov.br/sala-deimprensa/notas-a-imprensa/2010/04/07/brasil-eua-acordo-sobre-cooperacao-em-defesa. Acesso em: 26 set.2013. 
militares, educação e treinamento; não-proliferação; cooperação militar; segurança marítima; segurança energética; emergências relacionadas com desastres; preparação para atuação em forças de paz e operações humanitárias etc. $^{65}$ Entre 1994 e 2006, 34 países se associaram ao mecanismo, inclusive a Rússia e outros que pertenciam à esfera de influência da antiga União Soviética. Em 2012, seis desses países já haviam se tornado membros da OTAN e ainda existiam outros 22 países participantes. ${ }^{66}$ A partir de 2010, o programa foi alterado para abrir a possibilidade de participação de outros países, particularmente daqueles componentes do Diálogo do Mediterrâneo e da Iniciativa de Cooperação de Istambul. Hoje, as possibilidades de cooperação incluem um cardápio de cerca de 1600 atividades. $^{67}$

No âmbito multilateral, existem inúmeros mecanismos relacionados com a diplomacia de defesa. ${ }^{68}$ Alguns estão associados à organizações internacionais, tratados e alianças, outros são constituídos entre os Estados, normalmente, de caráter regional e existem, ainda, aqueles de caráter global ou inter-regional. Embora as principais potências mundiais, especialmente os EUA, tenham uma posição relevante na promoção desses mecanismos, as potências regionais também desenvolvem iniciativas nesse campo.

A ONU, como uma organização internacional de caráter global, possui, na sua estrutura, um departamento que serve de instância de assessoramento para temas de Defesa, incluindo a preparação e o controle das operações de paz, no que concerne às questões operacionais. O Departamento de Operações de Paz possui uma estrutura organizacional e normas e regras que orientam as práticas por ele desenvolvidas, dentre as quais aquelas que tratam de diversas atividades relacionadas à manutenção da paz e às atividades de reconstrução pós-conflito, desmobilização e reintegração, reforma dos setores de segurança, treinamento etc. No desenvolvimento das suas atividades, outras práticas são, também, levadas a

\footnotetext{
${ }^{65}$ Disponível em: http://www.nato.int/docu/comm/49-95/c940110b.htm http://www.nato.int/cps/en/natolive/topics_84336.htm?. Acesso em 01 nov.2013.

${ }^{66}$ Disponível em: http://www.nato.int/cps/en/natolive/topics_82584.htm. Acesso em: 01 nov.2013. ${ }^{67}$ Disponível em: http://www.nato.int/cps/ar/SID-7EBBEE3E6B770FDC/natolive/topics_50349.htm. Acesso em: 01 nov.2013.

${ }^{68}$ Multilateralismo é entendido como: "a coordenação de relações entre três ou mais Estados, de acordo com um conjunto de princípios" (Herz e Hoffman, 2004, p.19).
} 
efeito, tais como a proteção de civis, a proteção do meio-ambiente e a sustentabilidade e as políticas de gênero para as forças de paz. ${ }^{69}$

No âmbito das Américas, a Organização dos Estados Americanos (OEA), fundada em 1948, é o mais antigo organismo regional do mundo, como uma expressão do "sistema interamericano," que se constituiu, no tempo e no espaço, desde o final do século XIX. A OEA conta com a Junta Interamericana de Defesa (JID) como um dos seus organismos. Criada em 1942, ela é a organização militar e de defesa mais antiga existente no mundo, prestando "serviços de assessoramento técnico, consultivo e educacional em assuntos militares e de defesa no Hemisfério". A Junta possui um Conselho de Delegados, uma secretaria e o Colégio Interamericano de Defesa, criado em $1962 .^{70}$

Ainda no âmbito hemisférico, os EUA promoveram a Cúpula das Américas em 1994, na qual 33 chefes de governo democraticamente eleitos se reuniram para discutir temas da região. Como um desdobramento desse encontro, no ano seguinte, o Secretário de Defesa daquele país tomou a iniciativa de promover um mecanismo regional, no contexto de uma "nova abordagem" para as relações de segurança e defesa no pós-Guerra Fria, consoante com a estratégia de segurança nacional dos EUA de "engajamento e alargamento". As Conferências de Ministros da Defesa das Américas realizaram a sua primeira reunião em 1995, na cidade de Williamsburg, contando com a participação de ministros de 34 países da região. ${ }^{71}$ Alguns temas de destaque foram: a consolidação da democracia, o controle civil sobre os militares e o fomento da confiança mútua na região. Os "princípios de Williamsburg” incluem, dentre outros, a transparência em questões de Defesa, a negociação e a troca de informações. As Conferências continuam sendo realizadas, normalmente, a cada dois anos. ${ }^{72}$

Iniciativas desse tipo, sob a égide de uma superpotência, podem conviver com outras, de mesmo nível, de caráter, também, regional, promovidas por outros Estados, muitas vezes, como uma expansão para novas áreas de mecanismos políticos constituídos na crença de uma identidade e interesses comuns. No caso

\footnotetext{
${ }^{69}$ Mais detalhes estão disponíveis em: http://www.un.org/en/peacekeeping/issues/. Acesso em: 21 out.2013.

${ }^{70}$ Maiores detalhes sobre a JID estão disponíveis em: http://www.jid.org/quienes-somos. Sobre o Colégio Interamericano, ver: http://www.colegio-id.org/es/aboutIADC_esp.shtml. Acessos em: 25 set.2013.

${ }^{71}$ Esse mecanismo é também conhecido como o "Processo de Williamsburg".

72 Disponível em: http://www.cdmamericas.org. Acesso em: 19 nov.2013.
} 
da América do Sul, em 2004, os países da região, incentivados pelo Brasil, estabeleceram, no âmbito político-econômico, a Comunidade Sul-Americana de Nações (CASA). ${ }^{73}$ Esse mecanismo propiciou a Reunião de Ministros de Defesa, ocorrida em 2006, em Bogotá, na qual foram abordados temas relativos às ameaças comuns à América do Sul; o papel das Forças Armadas frente à essas ameaças; e o fomento da confiança mútua e dos mecanismos de resolução pacífica de possíveis conflitos entre os países da região. $\mathrm{Na}$ ocasião, foram assumidos compromissos para a limitação de gastos militares, estabelecimento do controle de armas convencionais e incremento de medidas de confiança mútua. Ao final da reunião, foi assinada a "Declaração de Bogotá."74

A transição da CASA para outro organismo político-econômico mais robusto, criado em 2008, denominado União das Nações Sul-Americanas (UNASUL), favoreceu a criação do Conselho de Defesa Sul-Americano (CDS), estabelecido por decisão expressa dos Chefes de Estado e de Governo, que definiram, através de Declaração, os princípios, objetivos e estrutura e o funcionamento dessa instância de "consulta, coordenação e cooperação" no âmbito da Defesa. No documento, semelhante à estrutura da UNASUL, além da presidência e da secretaria, foram estabelecidas duas instâncias principais: a dos ministros da Defesa e a dos vice-ministros ou equivalentes. Esta última, se constituindo em uma instância executiva (BRASIL, 2008). O CDS ainda possui na sua estrutura um Centro de Estudos Estratégicos de Defesa, que tem como missão gerar e disseminar um pensamento estratégico sul-americano em temas de defesa e segurança regional e internacional. ${ }^{75}$

Além dos mecanismos que contam com instâncias decisórias no nível dos ministérios da Defesa, há outros constituídos entre as Forças Armadas. No âmbito das Américas, eles existem entre as marinhas, os exércitos e as forças aéreas. $\mathrm{O}$ mais abrangente é a Conferência Naval Interamericana (CNI), que remonta ao ano de 1959, criada para ser um foro de discussão e intercâmbio de ideias e conhecimentos, estimulando as relações entre as marinhas dos Estados participantes, com o propósito de promover a solidariedade hemisférica. Para

\footnotetext{
${ }^{73}$ A Declaração de Cuzco, de 08 de dezembro de 2004, estabelece as bases para o mecanismo, cuja primeira reunião foi realizada, em 2005, no Brasil.

${ }^{74}$ Brasil. Ministério da Defesa. Sumário Executivo da VII POLMIL. Brasília, Nov.2006.

${ }^{75}$ Disponível em: http://www.ceedcds.org.ar/Portugues/01-CEED/06-Acordo-de-Sede.html. Acesso em: 18 nov.2013.
} 
facilitar a comunicação e a troca de informações, foi criada, em 1962, a Rede Naval Interamericana de Telecomunicações (RNIT), com uma secretaria atualmente sediada nos EUA. Participam da CNI dezenove países, e a JID, representada por uma delegação sem direito a voto, mas com direito a voz.

Desde a sua origem, a CNI tem incrementado sua institucionalização. Há um Conselho dos Delegados constituído, normalmente, pelos comandantes das marinhas ou chefes de Estado-Maior, e uma secretaria-geral. Há normas denominadas "Bases do Acordo", que estabelecem um conjunto de regras que regulam o funcionamento do mecanismo, inclusive a sua periodicidade, que pode ser anual ou, no máximo, bianual. As decisões acordadas têm um caráter de recomendações e são registradas no "Repertório", documento oficial que contém, inclusive, as concordâncias e divergências surgidas nas discussões que resultaram em recomendações. A CNI se configura uma rede, pois já foram por ela criadas várias Conferências Navais Interamericanas Especializadas, normalmente, com representantes do nível de almirantes, que tratam de temas específicos de interesse das marinhas, tais como, educação, inteligência, telecomunicações, ciência e tecnologia etc., e que se regem, também, por meio das "Bases para o Acordo". 76

Logo após a CNI, foi criada a Conferência dos Exércitos Americanos, em 1960, com a finalidade de debater e intercambiar ideias e experiências, e incrementar a colaboração e a integração entre os Exércitos da região, "contribuindo para a segurança e o desenvolvimento democrático dos países membros". Conta, hoje, com 20 países participantes e cinco Estados e organizações observadoras, incluindo a JID. O mecanismo, cujas reuniões ocorrem a cada dois anos, está institucionalizado com normas e estrutura estabelecidas. Da mesma forma que nas CNI, existem várias conferências especializadas e ad hoc, tais como as relacionadas com ciência e tecnologia, temas legais, meio-ambiente, relações civis-militares etc. ${ }^{77}$

Ainda no âmbito interamericano, existe o Sistema de Cooperação entre as Forças Aéreas Americanas, criado em 1961, com o propósito de "promover os

\footnotetext{
76 Maiores detalhes das Conferências existentes podem ser encontrados em: http://www.public.navy.mil/comusnavso-c4f/iantn/Pages/InterAmericanNavalConferences.aspx. ${ }^{77}$ Em 2012 foi realizada uma conferência sobre temas legais relacionados com a atuação dos exércitos em operações de paz e desastres naturais. Disponível em: http://www.army.mil/article/84460/Conference_of_American_Armies_ends_legal_conference_hos ted_by_Army_South_chaired_by_CG_of_U_S_JAG_S/. Para detalhes sobre as CEA, ver: https://www.redcea.com/about/SitePages/Home.aspx. Acessos em: 26 set.2013.
} 
laços de amizade, cooperação e apoio mútuo entre os seus membros". O organismo tem uma carta constitutiva, que estabelece a estrutura e as normas de funcionamento, inclusive em relação a distintivos, lemas e símbolos. O máximo nível decisório é a Conferência dos Chefes das Forças Aéreas Americanas, que se reúne anualmente. Há, ainda, uma Junta de Avaliação e Planejamento, uma secretaria permanente e vários comitês especializados. A institucionalização se estende para a produção de planos de ação e manuais sobre temas de interesse do sistema, como, por exemplo, os que tratam da ajuda humanitária e desastres. ${ }^{78}$

No âmbito dos países do Mercado Comum do Sul (MERCOSUL), a Reunião do Comitê de Comandantes de Exército dos Países do MERCOSUL e Associados, já está na sua décima primeira edição. O mecanismo tem como objetivos, principais, a troca de informações e a cooperação entre os seus membros. No entanto, não está integrado na estrutura do MERCOSUL, tratandose de uma iniciativa dos Exércitos dos países que o compõem. ${ }^{79}$

Outros mecanismos multilaterais podem ter um caráter inter-regional. Alguns podem ser fruto de mecanismos político-culturais, como é o caso da Comunidade de Países de Língua Portuguesa (CPLP), estabelecida em 1996, baseada na crença da existência de "laços históricos, étnicos e culturais comuns," que propiciariam o incremento das relações entre os oito países membros. Fundamentada na solidariedade, a CPLP busca possibilitar, entre os seus membros, "a concertação político diplomática, a cooperação em todos os domínios e a promoção e difusão da língua portuguesa."

No que concerne à diplomacia de defesa, em 1998 foram estabelecidas as reuniões periódicas de ministros da Defesa e de chefes de Estado-Maior, e decidida a criação de um Centro de Análises Estratégicas, com a missão de pesquisar, estudar e difundir temas estratégicos de interesse da Comunidade. $\mathrm{O}$ Centro, em funcionamento desde 2002, possui uma estrutura centralizada e núcleos nos países membros. Para apoiar as reuniões, foi instituído, em 1999, um

\footnotetext{
${ }_{78}^{78}$ Para maiores detalhes sobre o sistema, ver: http://www.sicofaa.org. Acesso em: 26 set.2013.

79 Disponível em: http://www.adesg.net.br/noticias/reuniao-integra-comandantes-de-exercito-domercosul-e-associados. Acesso em: 18 nov.2013.

${ }^{80}$ Para uma descrição sucinta da CPLP ver: http://www.itamaraty.gov.br/temas/mecanismos-interregionais/cplp. Acesso em: 27 set. 2013.
} 
secretariado permanente, com sede em Lisboa. ${ }^{81}$ Como um desdobramento da decisão dos chefes de governo da CPLP de desenvolver uma política para os oceanos, inclusive relacionada com a segurança marítima, criou-se, em 2010, a Reunião de Ministros de Assuntos do Mar, com periodicidade bianual, com um secretariado técnico permanente e um regimento interno, que estabelece as normas para o seu funcionamento. ${ }^{82}$

$\mathrm{Na}$ África, existem, também, diversos mecanismos que se inserem na moldura mais ampla da chamada Arquitetura de Paz e Segurança da África. No nível continental, esse arranjo tem a União Africana (UA), formada por 54 países, cuja ata constitutiva foi aprovada em 2000, e entrou em vigor em $2001 .^{83} \mathrm{O}$ Conselho de Paz e Segurança da União Africana, que possui um comitê militar e uma estrutura para o deslocamento de uma força de paz, constitui um dos seus órgãos. A UA, no seu Departamento de Paz e Segurança, possui três divisões: Segurança e Defesa, Apoio às Operações de Paz, e Administração de Conflitos e Reconstrução pós-Conflito, que são responsáveis por diversas práticas relacionadas com a diplomacia de defesa, incluindo aquelas relacionadas com a política de reconstrução e desenvolvimento pós-conflito, desmobilização e reintegração e reforma dos setores de segurança. ${ }^{84}$

A UA possui, ainda, um Comitê Técnico Especializado em Defesa, Segurança e Proteção, que envolve os ministros da Defesa e de Segurança e de Proteção dos Estados-membros, e que se reúne periodicamente para definir os rumos da agenda de segurança e defesa daquela organização. Esse comitê conta, também, com a assessoria das reuniões de Chefes de Estado-Maior africanos e dos Chefes dos Serviços de Segurança e Proteção. ${ }^{85}$

Existem, ainda, no continente africano, vários mecanismos sub-regionais. A Comunidade Econômica dos Estados da África Ocidental, composta de quinze

\footnotetext{
${ }^{81}$ Uma visão do estatuto do Centro está disponível em: http://caecplp.comunidades.net/index.php?pagina=1660336538. Acesso em: 26 set.2013

${ }^{82}$ Disponível em:

http://www.cplp.org/Files/Billeder/cplp/militar/Regimento\%20Interno\%20RMAM.pdf. Acesso em 07 mar.2014.

$83 \mathrm{O}$ processo que culminou com a constituição da organização pode ser visto em: http://www.au.int/en/about/nutshell. Acesso em: 22 out.2013.

84 Mais detalhes estão disponíveis em: http://www.peaceau.org/en/page/6-defense-and-securitydivision e http://www.peaceau.org/en/page/7-peace-support-operations-division. Acesso em: 21out. 2013.

85 Disponível em: http://www.peaceau.org/uploads/ex-cl-698-xx-e.pdf. Acesso em: 22 de out.2010.
} 
países, estabeleceu, no estatuto da organização, um mecanismo de prevenção de conflito, manutenção da paz e segurança. O capítulo 13 do Protocolo relativo ao mesmo, institucionaliza o comitê de ministros da Defesa dos países membros, que se reúne periodicamente. Há, ainda, um comitê de Chefes de Estado-Maior, que faz parte da Comissão de Defesa e Segurança. ${ }^{86}$

No Sul da África, desde 1977, o Comitê de Segurança e Defesa Interestados atua como um fórum para os temas de cooperação nesses campos. ${ }^{87} \mathrm{Com}$ o estabelecimento, em 1992, da Comunidade de Desenvolvimento da África Austral, foi criado o Órgão de Política, Segurança e Defesa dos 15 países membros, como uma instituição formal da Comunidade para tratar de temas político-estratégicos, forças de paz, cooperação, direitos humanos etc., que possui um Comitê Ministerial ligado à Secretaria Executiva, do qual fazem parte, dentre outros, os ministros da Defesa e das Relações Exteriores. Em 2001, um novo protocolo de cooperação política, segurança e defesa foi acordado, estabelecendo uma moldura legal, uma estrutura e objetivos mais claros. Esse protocolo foi alterado em 2009. Os documentos mantiveram o Órgão e o Comitê Ministerial, do qual fazem parte os ministros das Relações Exteriores, da Defesa e da Segurança Pública e Estatal. Ligados a esse organismo, existem dois subcomitês: o que agrega os mais altos representantes das relações exteriores e o Comitê de Segurança e Defesa Interestatal, que reúne os ministros da defesa e da segurança. $^{88}$

A Comunidade Econômica dos Estados da África Ocidental foi estabelecida em 1975 e possui quinze estados-membros. Em 1999, a organização estabeleceu, por meio de um protocolo, um mecanismo para a prevenção de conflitos, manutenção da paz e da segurança. Esse órgão possui uma estrutura organizacional com vários componentes, sendo um deles o Conselho de Mediação de Segurança, do qual fazem parte os ministros das Relações Exteriores, da Defesa e da Segurança Interna, que se reúnem a cada três meses para avaliar a situação política e de segurança da região. O Conselho tem, como alguns dos seus órgãos, a Secretaria Executiva, que possui um Departamento de Defesa e

\footnotetext{
86 Protocolo pode ser visto em: http://www.comm.ecowas.int/sec/index.php?id=ap101299\&lang=en. Acesso em: 30 set.2013.

87 Disponível em: http://www.sadc.int/themes/politics-defence-security/defence/. Acesso em: 30 set.2013.

${ }^{88}$ Disponível em: http://www.sadc.int/documents-publications/show/809. Acesso em: 30 set.2013
} 
Segurança, a Comissão de Segurança e Defesa, da qual fazem parte, dentre outros, os chefes de Estado-Maior e o Grupo de Monitoramento de Cessar-Fogo, que, dentre outras funções, exerce aquelas relacionadas com as forças de paz, intervenções humanitárias e ajuda em casos de desastres. ${ }^{89}$

A Comunidade Econômica da África Central constituiu, em 2000, o Conselho da Paz e Segurança, como um "órgão para o diálogo político e militar" entre os países da região. O documento de criação entrou em vigor em 2004, e estabelece dois níveis decisórios: o dos Chefes de Estado e de Governo, e o que reúne os ministros das Relações Exteriores, e da Segurança e da Defesa. Como parte do Conselho, existe uma Comissão de Defesa e Segurança que reúne, os chefes de Estado-Maior dos exércitos e os comandantes das forças de segurança publica dos estados-membros; e uma força de paz multinacional não permanente, que se constitui, quando necessário, para atuar, inclusive, em ações humanitárias. ${ }^{90}$

A Comunidade da África Oriental, composta por Quênia, Tanzânia e Uganda, possui um comitê setorial de cooperação em defesa e um comitê de segurança. Em 2006, foi aprovada pelos Estados-membros a Estratégia para a Paz e Segurança Regional, cuja visão é garantir um ambiente seguro e pacífico, que permita o desenvolvimento econômico e social, através da cooperação entre os três Estados. ${ }^{91}$

A institucionalização de mecanismos multilaterais da diplomacia de defesa também se espalha pela Ásia, normalmente, como um desdobramento de organismos políticos mais amplos ou como um desenvolvimento da confiança produzido por um mecanismo da área de Defesa, como é o caso da Organização de Cooperação de Shangai (OCS) Estabelecida em 2001, tem, como membros, China, Rússia, Cazaquistão, Quirguistão, Tajiquistão e Uzbequistão; como observadores, Afeganistão, Índia, Irã, Paquistão e Mongólia; e, como "parceiros de diálogo", Bielorússia, Turquia e Sri Lanka. ${ }^{92}$ Sua constituição remonta o mecanismo de Xangai Cinco, criado nos anos 90, com o propósito de incrementar

\footnotetext{
${ }^{89} \mathrm{O}$ texto completo do Protocolo está disponível em: http://www.comm.ecowas.int/sec/index.php?id=ap101299\&lang=em. Acesso em: 23 out.2013 ${ }^{90}$ Disponível em: http://www.africa-union.org/root/au/recs/eccas.htm. Acesso em: 23 out.2013

${ }^{91}$ Disponível em: http://www.africa-union.org/root/au/recs/EAC.htm\#history. Acesso em: 23 out.2013.

92 The Shangai Cooperation Organization. Disponível em: http://www.sectsco.org/EN/. Acesso em : 16 jan.2012.
} 
medidas de confiança mútua e desarmamento nas fronteiras entre os cinco primeiros países-membros, resultando em dois tratados no âmbito da Defesa, relacionados com o incremento da confiança militar e redução de tropas. Esse mecanismo foi se institucionalizando por meio de reuniões periódicas e práticas regulares, de tal forma que a confiança entre os Estados-membros gerou as condições de possibilidade de ampliação da agenda para outras áreas no campo político, diplomático, de comércio, de segurança etc. ${ }^{93}$

A Organização tem como alguns dos seus objetivos, contribuir para a implementação da confiança mútua, o desarmamento, e a constituição de parcerias, inclusive no campo da segurança, na Ásia Central. Engloba, como um dos seus mecanismos, as Conferências de Chefes de Agências, cuja principal função é o estudo e a solução de questões de áreas específicas. A área da Defesa é tratada na reunião de ministros dessa pasta e a cooperação nesse âmbito se estende para temas como terrorismo, separatismo, extremismo, considerados como as prioridades da OCS, e a imigração ilegal, o tráfico ilegal de drogas e armas, e as ameaças à segurança da informação. ${ }^{94}$ Os membros se reúnem periodicamente, definindo objetivos e estabelecendo normas sobre a cooperação no campo da Defesa. $^{95}$

A Associação das Nações do Sudeste Asiático (ASEAN) foi criada em 1967 e, hoje, reúne Brunei, Camboja, Indonésia, Laos, Malásia, Mianmar, Filipinas, Cingapura, Tailândia e Vietnã. A carta constitutiva da organização ressalta os interesses mútuos, a interdependência entre os seus povos e uma visão e uma identidade comuns como alguns dos elementos para a sua constituição, na busca da cooperação que possibilite paz e prosperidade na região. Na Associação, no conjunto de órgãos setoriais da denominada "comunidade política e de segurança”, inclui-se a Reunião de Ministros da Defesa da ASEAN (RMDA), criada em 2006, assessorada por uma instância, que reúne os altos funcionários desses ministérios. ${ }^{96}$

\footnotetext{
${ }^{93}$ Disponível em: http://www.fmprc.gov.cn/eng/topics/sco/t57970.htm. Acesso em : 24 out.2013

${ }^{94}$ Shangai Cooperation Organization. Joint Communiqué of meeting of the Council of the Heads of the Member States of the Shanghai Cooperation Organisation commemorating the 10th anniversary of the SCO. Disponível em: http://www.sectsco.org/EN/2011.asp. Acesso: 12 jan.2012.

${ }_{95}$ Disponível em: http://english.people.com.cn/90786/8301568.html. Acesso em: 23 out.2013

${ }^{96}$ Disponível em: http://www.asean.org/archive/publications/ASEAN-Charter.pdf. Acesso em:23 out.2013.
} 
A RMDA se reúne anualmente, buscando promover a confiança e a transparência, e discutir os temas de segurança e defesa. Possui um programa de trabalho tri-anual, que envolve atividades relacionadas com a cooperação de segurança e defesa, constituição e compartilhamento de normas, prevenção e resolução de conflitos, e reconstrução pós-conflito. Temas como assistência humanitária e desastres naturais vêm se destacando na agenda, inclusive com a produção de normas, tais como o Conceito para o uso das Capacidades Militares da ASEAN na Assistência Humanitária e na Ajuda em casos de Desastres, e do Conceito de Defesa e Organizações da Sociedade Civil para a Cooperação na Segurança Não-Tradicional. ${ }^{97}$

A partir de 1997, a constituição do mecanismo político Cooperação da ASEAN mais Três, incluindo a China, o Japão e a Coréia do Sul, possibilitou a expansão dos membros das reuniões de ministros da Defesa, no denominado RMDA Mais, constituído em 2010, que se reúne periodicamente, e cujas normas foram adotadas naquele mesmo ano. Na ocasião, os ministros decidiram cooperar em cinco áreas: segurança marítima, contra-terrorismo, administração em caso de desastres, operações de paz e medicina militar. Para tanto, foram criados cinco grupos de especialistas nos temas. ${ }^{98} \mathrm{O}$ plano de trabalho da ASEAN mais Três para o decênio 2007-2017 estabelece, como algumas das suas orientações, o incremento das interações e cooperação de Defesa para a promoção da confiança e da transparência, a cooperação marítima, o contra-terrorismo, e a ajuda em casos de desastres e situações de emergência. ${ }^{99}$

A ASEAN se constituiu, também, em um elemento catalisador para a expansão do diálogo e cooperação entre outros países da região Ásia-Pacífico. Em 1994, foi criado o Fórum Regional, composto de 27 países, inclusive os EUA, a União Europeia, a Rússia e a China, considerado um importante mecanismo no diálogo da segurança regional, com ênfase, inclusive, na diplomacia preventiva. $\mathrm{Na}$ área da Defesa, existem diversas instâncias e práticas, denominadas Diálogo de Funcionários da Defesa, que conta com as reuniões de diretores de instituições de ensino, os exercícios militares, os seminários e a produção de normas sobre

\footnotetext{
${ }^{97}$ Disponível em: http://www.asean.org/communities/asean-political-securitycommunity/category/asean-defence-ministers-meeting-admm. Acesso em: 18 nov.2013.

98 Disponível em: http://www.asean.org/communities/asean-political-securitycommunity/category/asean-defence-ministers-meeting-admm. Acesso em: 23 out.2013.

${ }_{99}$ Disponível em http://www.mofa.go.jp/region/asia-paci/asean/conference/asean3/plan0711.pdf. acesso em:24 out.2013.
} 
temas de segurança e defesa. ${ }^{100}$ Além da abrangência regional, esse fórum tem uma característica importante, ao congregar a maioria dos Estados mais relevantes da política internacional no diálogo de segurança e defesa. A diversidade dos atores e dos interesses envolvidos contribuiu para a constituição de um mecanismo sui generis, no qual uma menor institucionalização foi um fator que ajudou na manutenção do diálogo, persuasão e socialização entre tantos e tão variados atores (JOHNSTON, 1999).

O fim da Guerra Fria e a dissolução da União Soviética ensejou a constituição, em 1991, da Comunidade de Estados Independentes (CEI), liderada pela Rússia e mais os seguintes países: Armênia, Azerbaijão, Bielorússia, Cazaquistão, Quirguistão, Moldávia, Tajiquistão, Turcomenistão, Ucrânia e Uzbequistão. Na área da Defesa, existem o Conselho de Ministros da Defesa e o Conselho dos Comandantes das Tropas de Fronteira da CEI. ${ }^{101}$

Outro organismo, euro-asiático, inicialmente voltado para a segurança coletiva tradicional, mas que, atualmente, vem ampliando a cooperação para outros campos, é a Organização do Tratado de Segurança Coletiva, do qual participam Armênia, Bielorússia, Rússia, Cazaquistão, Quirguistão, Tajiquistão e Uzbequistão. O tratado, assinado em 1992, tornou-se uma organização em 2002. Existe uma ampla interação e institucionalização no âmbito da segurança e da defesa. O Conselho de Ministros da Defesa, juntamente com o Conselho de Ministros das Relações Exteriores e o Comitê dos Secretários dos Conselhos de Segurança, formam o tripé consultivo e executivo da governança da Organização, que ainda possui um Estado-Maior Conjunto. O mecanismo tem avançado em diversas áreas, tais como: cooperação militar-econômica, cooperação-técnica militar e formação de pessoal, anti-terrorismo, exercícios militares, e produção de normas. ${ }^{102}$

A Liga Árabe e o Conselho de Cooperação para Países Árabes do Golfo (CCPAG) são dois outros exemplos de organizações que possuem mecanismos relacionados com a Defesa. A Liga, criada em 1945, tem, hoje, 21 membros e está institucionalizada com órgãos e normas que regulam o seu funcionamento. ${ }^{103} \mathrm{O}$

\footnotetext{
${ }^{100}$ Disponível em: http://www.dfat.gov.au/arf/. Acesso em: 24out. 2013.

${ }^{101}$ Disponível em: http://www.cisstat.com/eng/site-map.htm. Acesso em: 04 nov.2013.

${ }^{102}$ Disponível em: http://www.odkb.gov.ru/start/index_aengl.htm. Acesso em: 24 out.2013.

103 A Síria foi suspensa da Liga devido à guerra civil que vem sendo travada naquele país no governo de Bashar al-Assad.
} 
Conselho de Defesa Conjunta foi estabelecido após o Tratado de Defesa Mútua e Cooperação Econômica, em 1950. É composto pelos ministros das Relações Exteriores e da Defesa de todos os países membros. ${ }^{104}$

Já o CCPAG é formado pelo Omã, Emirados Árabes Unidos, Arábia Saudita, Qatar, Bahrein e Kuwait. Sua Carta de criação é datada de 25 de maio de 1981. Sua constituição foi assentada na crença da existência de similaridades entre os países membros, em relação à existência de uma nação árabe e à aderência ao islamismo. Essa organização política e econômica está institucionalizada com diversos órgãos e instâncias. No campo da Defesa, por decisão do Conselho Ministerial, em 1981, foi realizado o primeiro Encontro dos Chefes de Estado Maior, para debater diversas recomendações feitas pelos ministros, relacionadas à promoção da cooperação militar entre os países membros. No ano seguinte, foi realizado o primeiro Encontro de Ministros da Defesa. A cooperação nessa área vem crescendo desde então, gerando diversos resultados, tais como o estabelecimento de uma força militar conjunta, denominada "Forças Conjuntas Escudo Al-Jazeera"; um acordo de defesa, que contém, inclusive, um sistema de segurança coletiva; um sistema de comunicações das Forças Armadas; exercícios militares conjuntos; e unificação de currículos das escolas militares. ${ }^{105}$

Na Europa, um dos principais mecanismos multilaterais é a Organização para a Segurança e Cooperação na Europa (OSCE), que possui 57 Estadosmembros, e é considerada a maior organização de segurança regional do mundo. ${ }^{106}$ Sua constituição remonta os anos 1970, quando foi instituída a Conferência de mesmo nome, como um fórum de diálogo e negociação entre os países do Ocidente e do Oriente. A Ata Final de Helsinque foi o documento que a normatizou, criando inclusive, o comitê político-militar. O fìm da Guerra-Fria permitiu que a Conferência alterasse sua abordagem, adaptando-a para o novo contexto e incrementando sua institucionalização como um órgão permanente. Assim, ela se constituiu em um "fórum político para negociações e decisões relacionadas com a prevenção de conflitos, a administração de crises e a

\footnotetext{
${ }^{104}$ Disponível em: http://avalon.law.yale.edu/20th_century/arabjoin.asp. Acesso em:24 out.2013.

${ }^{105}$ Disponível em: http://www.gcc-sg.org/eng/index8409.html?action=Sec-Show\&ID=49. Acesso em: 24 out.2013.

${ }^{106}$ Os EUA participam ativamente da Organização, com especial interesse nas questões de controle de armas e outros temas políticos- militares. Uma visão resumida dos interesses norteamericanos na OSCE está disponível em: http://osce.usmission.gov/usandosce.html. Acesso em: 11 nov.2013.
} 
reabilitação pós-conflito." Os temas político-militares fazem parte da sua agenda de modo amplo, relacionados com controle de armas, contra-terrorismo e medidas de fortalecimento da confiança e da segurança. Esse último está normatizado, principalmente, pelo Código de Conduta, de 1994, e pelo Documento de Viena de 2011, que detalha uma série de medidas a serem adotadas pelos Estados-membros para incrementar a transparência no âmbito da Defesa. ${ }^{107}$ Embora não seja um mecanismo de diplomacia de defesa propriamente dito, a OSCE trata de temas à ela relacionados e suas normas influenciam vários outros mecanismos europeus considerados como tal.

Outro importante mecanismo é a OTAN, uma aliança político-militar constituída em 1949, no período da Guerra Fria, congregando, atualmente, mais de duas dezenas de países. Seu propósito é assegurar a liberdade e a segurança dos países membros. Politicamente, propõe-se a promover "os valores democráticos" e a consulta e a cooperação em temas de segurança e defesa entre os Estados membros, contribuindo para a confiança e a prevenção de conflitos. Caso decida pela opção militar, a OTAN estabelece que pode atuar sob um mandato da ONU ou com outros Estados e organizações internacionais ou, até mesmo, sozinha.

A Organização possui, como órgão político decisório mais importante, o Conselho do Atlântico Norte, com representantes de cada Estado-membro, que se reúnem pelo menos uma vez por semana. Existe, ainda, um Secretário-Geral, o funcionário civil de mais alto nível da Organização, que tem sob seu comando uma equipe internacional. ${ }^{108}$ No âmbito da Defesa, existe uma estrutura de governança complexa. O órgão de mais alto nível é o Comitê Militar, que possui um presidente e é composto pelos chefes de Estado-Maior dos países membros. Este organismo conta com um corpo executivo, o Estado-Maior Internacional e uma estrutura militar com dois comandos: o Comando Aliado de Operações e o Comando Aliado para a Transformação. ${ }^{109}$

Desde o fim da Guerra Fria, a Organização tem estendido sua atuação para a inclusão de novos países e para o diálogo além da área abrangida pelos Estadosmembros. Em 1994, foi criado o Diálogo do Mediterrâneo, incluindo Egito, Israel, Jordânia, Mauritânia, Marrocos e Tunísia, com o propósito de contribuir para a

\footnotetext{
${ }^{107}$ Disponível em: http://www.osce.org/fsc/86597. Acesso em: 08 nov.2013.

${ }^{108}$ Disponível em: http://www.nato.int/nato-welcome/index.html. Acesso em: 01nov. 2013

${ }^{109}$ Disponível em: http://www.nato.int/docu/review/2007/issue1/portuguese/interview.html. Acesso em: 01 de nov.2013.
} 
segurança e a estabilidade dessa área. Os ataques terroristas de 11 de setembro de 2001 contribuíram para que a OTAN considerasse que a instabilidade em Estados distantes das suas fronteiras poderia trazer consequências adversas para a Organização e que, portanto, sua área de atuação não deveria ser limitada ao perímetro geográfico dos países membros. Em sequência à ampliação das suas interações, em 2002 foi estabelecido o Conselho OTAN-Rússia e, em 2004, a Iniciativa da Cooperação de Istambul, a fim de incrementar a cooperação bilateral com países do Oriente Médio. ${ }^{110}$ A expansão da OTAN, não só em quantidade de membros mas, inclusive, na amplitude das suas atividades, mostra como um mecanismo de defesa voltado para as questões militares pode se transformar, também, em um fórum para uma ampla cooperação na área de segurança.

O Eurocorps é uma força multinacional criada em 1992, pela Alemanha e pela França, com a assinatura do La Rochelle Report.Trata-se de mecanismo permanente, organizado estruturalmente no padrão da OTAN, composto por militares de Bélgica, França, Alemanha, Luxemburgo e Espanha. Itália, Turquia e Polônia, que deverá se tornar membro pleno em 2016, são Estados associados. Essa força age com base no princípio da segurança coletiva e em situações emergenciais, apoiando as agências civis no caso de catástrofes. No Afeganistão, por exemplo, uma das suas tarefas é o desenvolvimento das forças de segurança do país, promovendo treinamento e equipamento. ${ }^{111}$

O Pacto de Estabilidade para a Europa do Sudeste foi adotado em junho de 1999, com a participação de mais de 40 Estados e outras organizações internacionais, com o propósito de desenvolver uma estratégia de prevenção de conflitos, substituindo as posturas intervencionistas reativas, e fortalecer os países da região, na busca de "paz, prosperidade, democracia e direitos humanos." Baseava-se na crença de que a paz só poderia ser atingida por meio de três pilares: garantia da segurança, desenvolvimento da democracia e da prosperidade econômica, e o bem-estar social.

Além dos países da região, Albânia, Bósnia-Herzegovina, Bulgária, Croácia, Moldávia, Montenegro, Romênia, Sérvia e Macedônia, o Pacto contava com a União Europeia, que tinha o principal papel em seu desenvolvimento, os EUA, Rússia, Japão, Canadá, Suíça, Noruega e a Turquia. Existiam, também,

\footnotetext{
${ }^{110}$ Disponível em: http://www.nato.int/history/nato-history.html. Acesso em: 01 nov.2013.

${ }^{111}$ Disponível em: http://www.eurocorps.org/. Acesso em: 06 nov.2013.
} 
algumas organizações internacionais participantes: ONU, OTAN, o Fundo Monetário Internacional e os bancos Mundial, de Investimento Europeu, de Reconstrução e Desenvolvimento Europeu. Havia, ainda, alguns outros participantes regionais, tais como a Cooperação Econômica do Mar Negro e a Iniciativa Centro-Europeia. $^{112}$

O Pacto se orientava pela possibilidade de uma futura integração à União Europeia. Assim, como uma etapa intermediária, diversos Acordos de Estabilização e Associação foram firmados entre os países que não possuíam relação contratual com aquela organização. A iniciativa se institucionalizou com a criação de um Escritório do Coordenador Especial sediado em Bruxelas, uma mesa regional e três mesas de trabalho, sendo que essas últimas cuidavam dos temas de segurança. Dividia-se em dois subgrupos: segurança e defesa, e justiça e assuntos domésticos. A área da Defesa se fundamentava na criação de medidas de confiança mútua e na promoção do controle de armas, tendo sido criado um Centro Regional de Verificação do Controle de Armas. Além disso, foi implantado um programa para a reforma do sistema de defesa e de ajuda a militares excedentes a se prepararem para entrar no mercado de trabalho civil. ${ }^{113}$

Em 2008, o Pacto foi transformado no Conselho de Cooperação Regional, com o propósito de promover a cooperação na Europa do Sudeste. Deste organismo, fazem parte 46 países e organizações. O Conselho tem um secretáriogeral, uma secretaria e um escritório de ligação em Bruxelas. Como uma das suas instâncias institucionais na área da segurança e defesa, conta com a reunião bianual dos Ministros de Defesa, ${ }^{114}$ que se realiza desde 1996 e da qual participam como membros, Albânia, Bósnia e Herzegovina, Bulgária, Croácia, Grécia, Itália, Montenegro, Macedônia, Romênia, Sérvia, Eslovênia, Turquia e Ucrânia, e, como observadores, os EUA, a Geórgia e a Moldávia. ${ }^{115}$ O Programa de Trabalho 2011 2013 prevê a organização dos seguintes fóruns de cooperação em segurança: Diretores da Política de Defesa, Chefes da Inteligência Militar, ContraInteligência Militar e Autoridades da Segurança da Informação. ${ }^{116}$

\footnotetext{
112 Disponível em: http://www.stabilitypact.org/about/. Acesso em: 04 nov.2013.

${ }^{113}$ Disponível em: http://www.stabilitypact.org/about/achievements.asp. Acesso em: 04 nov.2013.

${ }^{114}$ Disponível em: http://www.rcc.int/pages/6/2/overview. Acesso em: 04 nov.2013.

115 Disponível em: http://www.rcc.int/pages/0/35. Acesso em: 04 nov.2013.

116 Disponível em: http://www.rcc.int/pages/17/8/security-cooperation. Acesso em: 18 nov.2013.
} 
Além desses fóruns de debates e coordenação, a cooperação na área de segurança engloba, ainda, a Iniciativa de Preparação e Prevenção contra Catástrofes, o Centro Regional de Intercâmbio de Informações da Europa do Sudeste e Oriental para o Controle de Armas Ligeiras e de Pequeno Calibre, o Fórum para Cooperação de Defesa dos Bálcãs Ocidentais, o Centro de Cooperação de Segurança, que era o antigo centro de controle de armas do Pacto, e a Carta Adriática, que é uma interação entre os EUA e alguns países da região, com foco no relacionamento com a OTAN. ${ }^{117}$

Existem outros mecanismos de diplomacia de defesa europeus que foram constituídos com foco em uma área específica, como é o caso da Organização de Cooperação Conjunta em Matéria de Armamentos, criada em 1996, com a participação plena de Bélgica, França, Alemanha, Reino Unido, Itália e Espanha. Outros membros, como Finlândia, Suécia, Polônia, Luxemburgo, Países Baixos e Turquia participam de, ao menos, um programa. A Organização busca fornecer arranjos mais eficazes e eficientes para a gestão de certos programas colaborativos na área de armamentos e está estruturada organizacionalmente com mecanismos de governança, sendo o principal deles o Conselho de Supervisão, constituído pelos ministros da Defesa dos Estados-membros, que, na prática, normalmente, são representados pelos seus altos funcionários especializados na área de armamentos. $^{118}$

Numa perspectiva semelhante, foi criada, em 2004, a Agência de Defesa Europeia. Dela participam todos os países da UE, com exceção da Dinamarca. Sua missão é ajudar o Conselho e os Estados-membros no "aprimoramento das capacidades de defesa para uma política comum de segurança e defesa". O mecanismo é um fórum para o diálogo entre os ministros de Defesa, principalmente, para a promoção de projetos de cooperação técnicos relacionados com a indústria de defesa. O principal instrumento de governança é o Corpo de Gestão, que reúne os ministros dos países da UE. A Agência está institucionalizada com normas e estrutura organizacional. ${ }^{119}$

Outros mecanismos são voltados para a área de força de paz, tal como a Cooperação das Nações da Europa Central para Apoio à Paz, criada em 1998, a

\footnotetext{
${ }^{117}$ Disponível em: http://www.rcc.int/pages/0/35. Acesso em: 04 nov.2013.

118 Disponível em: http://www.occar.int/10. Acesso em: 08 nov.2013.

119 Disponível em: http://www.eda.europa.eu/Aboutus/who-we-are/Organisation. Acesso em:06 nov.2013.
} 
partir de iniciativa da Áustria e com a participação de Croácia, Eslováquia, Eslovênia, Hungria, Romênia e Suíça. Seu objetivo específico é cooperar para as operações de paz. Além disso, propõe-se a ser um fórum de debates entre os Estados-membros em temas de segurança e defesa. ${ }^{120}$ A partir de 2005, sua agenda foi ampliada de temas estritamente militares para outros da área da política de Defesa e diálogo de segurança. Sua estrutura é composta de Presidência, Comitê de Gestão, Grupo de Planejamento e Coordenação, Grupos de Trabalho, Secretariado e Pontos de Contato Nacionais. O Encontro dos Ministros da Defesa configura a instância mais alta do organismo. ${ }^{121}$

Estônia, Lituânia e Letônia possuem, também, um mecanismo denominado Cooperação para Defesa do Báltico, que vem sendo paulatinamente constituído após a independência desses países, em 1991. Existe um Comitê Ministerial composto pelos ministros da Defesa, a quem cabe a orientação políticoestratégica. Há, ainda, o Comitê Militar, que reúne os Comandantes das Forças Armadas, responsável pela implementação das decisões ministeriais e pelo assessoramento em relação aos projetos e temas. O Acordo de Cooperação no Campo da Defesa e da Relação Militar, assinado em 2008, é o aparato normativo mais importante. Três projetos de longo prazo encontram-se sob a égide dessa cooperação: o Colégio de Defesa do Báltico, A Rede de Vigilância Aérea e o Esquadrão Naval. ${ }^{122}$

Dinamarca, Finlândia, Islândia, Noruega e Suécia, ao longo do tempo, constituíram diversos mecanismos de diálogo e cooperação no âmbito da Defesa, inclusive com reuniões periódicas dos ministros dessa pasta. Nesse contexto, em 2009, foi criada a Cooperação de Defesa, que foi incorporada, nesse mesmo ano, ao Conselho Nórdico, pelo Memorando de Entendimento sobre Cooperação Nórdica em Defesa. O seu propósito maior é fortalecer a defesa nacional dos países participantes, explorar as sinergias comuns e facilitar soluções comuns eficientes, inclusive na área de reforma dos sistemas de defesa, na área operacional e na de competitividade da indústria nesse campo. Encontra-se institucionalizada através de normas e reuniões periódicas do Comitê de Gestão

\footnotetext{
${ }^{120}$ Disponível em: http://www.cencoop.at/index.htm. Acesso em: 08 nov.2013.

${ }^{121}$ Disponível em: http://www.cencoop.at/cooperation/index_cooperation.htm. Acesso em: 06 nov.2013.

${ }^{122}$ Disponível em: http://www.mod.gov.lv/Par_aizsardzibas_nozari/Politikas_istenosana/Baltijas_valstu_milit_sadarb iba.aspx. Acesso em: 06 nov.2013.
} 
da Política Nórdica de Defesa, no nível ministerial e do Comitê de Coordenação Nórdica, no nível militar. ${ }^{123}$

O fórum do Mediterrâneo Ocidental é um mecanismo de segurança euromediterrâneo, criado em 1990 e relançado em 2001, que reúne cinco países da União do Magreb Árabe: Argélia, Líbia, Marrocos, Mauritânia e Tunísia, com cinco países da EU: Espanha, França, Itália, Malta e Portugal. É considerado pelos seus membros como um modelo de cooperação Norte-Sul, capaz de consolidar as complementaridades e solidariedades entre os Estados-membros. Dentre as principais atividades de cooperação, estão os encontros setoriais com foco em migração, iniciativas de transporte e defesa. ${ }^{124}$ Os ministros da Defesa começaram a se reunir em 2004, desde então, têm mantido encontros periódicos, com o objetivo de reafirmar a cooperação militar, com uma abordagem que inclui o desenvolvimento, principalmente por meio de medidas relacionadas com as operações de manutenção da paz, gestão de crises, segurança marítima etc. ${ }^{125}$

No âmbito mundial, em relação às forças de paz, um dos mais importantes mecanismos é a Iniciativa Global para as Operações de Paz, cujo propósito é incrementar a capacidade internacional para conduzir operações desse tipo. Foi promovido pelos EUA, em 2004, como uma contribuição ao plano de ação do G8, que tratava desse tema. Inicialmente, foi estabelecido para durar cinco anos, mas esse período foi estendido até 2014. Na sua primeira fase, o governo norteamericano treinou e equipou cerca de 75.000 pessoas, a maioria oriunda de países africanos. Na fase em curso, o programa mudou o foco para construir infraestrutura e capacidade própria de treinamento em determinados países, com o apoio da “comunidade internacional”. Sua administração está a cargo do Escritório de Assuntos Político-Militares do Departamento de Estado, em estreita colaboração com o Departamento de Defesa e o Estado-Maior Conjunto, os comandos militares regionais e outros órgãos do Departamento de Defesa. O programa tem contribuído com recursos para os departamentos de força de paz da

\footnotetext{
${ }^{123}$ Disponível em: http://www.norden.org/en/about-nordic-co-operation/agreements/treaties-andagreements/defence-affairs/memorandum-of-understanding-on-nordic-defence-cooperationnordefco. Acesso em: 08 nov. 2013.

${ }^{124}$ Disponível em:

http://www.diplomatie.ma/Portals/0/Conclusions\%20des\%20copresidences\%205plus5.pdf. Acesso em: 08 nov.2013.

${ }^{125}$ Disponível em:

http://www.diplomatie.ma/Politiqueétrangère/Méditerranée/DialogueenMediterraneeOccidentale/t abid/185/language/en-US/Default.aspx. Acesso em:08 nov.2013.
} 
UA e da ECOWAS, assim como de outros 45 centros de treinamento regionais e nacionais. $^{126}$

Nesse contexto, o Departamento de Estado, em colaboração com o Departamento de Defesa e o Comando Militar dos EUA para a África (AFRICOM), administra o programa Operações da Assistência de Contingência e Treinamento da África, com o objetivo de promover a capacidade e competência para realização de operações de paz dos países e instituições regionais desse Continente. Segundo o Departamento de Estado, desde 2007, foram treinados mais de 250.000 profissionais de vários países africanos, que participaram ou ainda participam de diversas operações de paz. ${ }^{127}$

Finalmente, dentre os mecanismos relacionados com uma atividade específica, vale a pena mencionar, no campo da inteligência, compartilhado pelos EUA, Grã-Bretanha, Austrália, Canadá e Nova Zelândia. Ele foi estabelecido em 1946, entre os dois primeiros países, pelo documento ultra-secreto conhecido como o Acordo UKUSA, com a finalidade de obter e trocar dados de inteligência. ${ }^{128} \mathrm{Em} \mathrm{1955,} \mathrm{o} \mathrm{documento} \mathrm{foi} \mathrm{alterado} \mathrm{e} \mathrm{os} \mathrm{demais} \mathrm{países} \mathrm{foram}$ incluídos como países da Commonwealth colaboradores do acordo. Esse grupo é conhecido como os "Cinco-Olhos", formado por um "clube de países de língua inglesa que, compartilham inteligência e cooperam intensamente em programas de vigilância" (BALL, 2013). Nos EUA, o órgão responsável pelo tema é a Agência de Segurança Nacional, subordinada ao Departamento de Defesa. ${ }^{129}$ Dois principais fatores contribuíram para que esse mecanismo ganhasse uma maior dimensão na coleta de dados: o desenvolvimento tecnológico das comunicações e a revolução digital, com o uso generalizado da internet e dos telefones celulares, e, mais tarde, a partir, principalmente, dos atentados de 11 de setembro, o

\footnotetext{
${ }^{126}$ Disponível em: http://www.state.gov/t/pm/rls/fs/2013/208094.htm. Acesso em 13 nov.2013.

${ }^{127}$ Disponível em: http://www.state.gov/r/pa/prs/ps/2013/02/203841.htm. Acesso em 13 nov.2013.

${ }^{128} \mathrm{O}$ documento que regia o mecanismo definia "inteligência de comunicação" como "todos os processos envolvidos na coleta, produção e disseminação da informação derivada da comunicação de outras nações," o que, segundo o Acordo, significava "todas as comunicações do governo, das Forças Armadas, de partidos políticos, agências , e inclusive, pessoa ou pessoas de outros países que possam conter informações de valor político, militar ou econômico". O teor do documento está disponível em: http://www.nsa.gov/public_info/_files/ukusa/agreement_outline_5mar46.pdf. Acesso em: 03fev.2014.

${ }^{129}$ Uma visão geral da Agência pode ser vista em: http://www.nsa.gov/about/mission/index.shtml. Acesso em: 03 fev.2014.
} 
argumento da necessidade de obter informações para prevenir o terrorismo (BALL e HOPKINS, 2013). ${ }^{130}$

A área de defesa tem ensejado, ainda, mecanismos relacionados à segurança marítima, no âmbito global e regional. No âmbito global, os EUA vêm promovendo, desde 1969, normalmente, a cada dois anos, o Simpósio Internacional sobre o Poder Marítimo, como um fórum de debates entre os chefes das marinhas e das organizações de guarda-costas existentes no mundo, com o propósito de incrementar a cooperação internacional relacionada com a segurança marítima. O Simpósio, que atualmente conta com a participação de mais de uma centena de Estados, é estruturado em sessões plenárias e painéis com temas de caráter geral e seminários específicos, geralmente, dividido por regiões. Constituise, também, em uma única oportunidade para os oficiais do mais alto posto da área naval interagirem com seus congêneres ao redor do mundo e estabelecerem o diálogo e formas de cooperação. Além da publicação dos seus anais, esses eventos têm motivado a produção de algumas normas, tais como o Manual Internacional de Operações Marítimas. ${ }^{131}$

O Simpósio tem contribuído para a constituição de mecanismos semelhantes de caráter regional, tais como os Simpósios Navais do Pacífico Ocidental, e o de Veneza. ${ }^{132}$ O primeiro, criado em 1988, se realiza bianualmente, com o propósito de ser um fórum de debates e incrementar a cooperação na segurança marítima e, em 2010, contava com vinte Estados membros e quatro observadores da orla do Oceano Pacífico. ${ }^{133} \mathrm{O}$ mecanismo tem aumentado sua institucionalização, possuindo uma "Carta" que normatiza o seu funcionamento, inclusive, com a criação de uma secretaria. Há normas para participação e responsabilidades dos membros e observadores, e a possibilidade de envolvimento de outras agências, inclusive de organizações não-governamentais. ${ }^{134}$

\footnotetext{
${ }^{130}$ A amplitude e profundidade dessa atividade passaram a ser públicas a partir da publicação, pela mídia, de documentos classificados, mostrando que essa vigilância era usada amplamente contra chefes de governo e de estado, em fóruns diplomáticos, organizações internacionais etc. (Bell, Hopkins, 2013).

${ }^{131}$ Disponível em: http://www.usnwc.edu/Publications/International-Sea-Power-SymposiumProceedings.aspx. Acesso em: 19 nov.2013.

${ }^{132}$ Disponível em: http://www.usnwc.edu/getattachment/51bb9e30-733a-4770-ac4a-

74ec42c0f6b1/ROP-16th.aspx. Acesso em: 29 out.2013.

${ }^{133}$ Disponível em:

http://www.mindef.gov.sg/imindef/press_room/official_releases/nr/2011/mar/25mar11_nr/25mar1 1_fs.html\#.Um_KlFNHIQ0. Acesso em: 29 out.2013.

${ }^{134}$ Disponível em: http://www.navy.mi.th/wpns2013/. Acesso em: 29 out.2013.
} 
O Simpósio Regional do Poder Marítimo de Veneza é promovido bianualmente pela marinha italiana, desde 1996, com a participação das marinhas litorâneas dos mares Mediterrâneo e Negro, e tem facilitado o diálogo entre os chefes navais e representantes do setor privado e de organizações internacionais, e alcançado outros resultados práticos, tal como a criação do Centro Virtual de Tráfego Marítimo Regional, adotado por cerca de 30 países. Os temas e tópicos são tratados regionalmente, em conformidade com aqueles discutidos, no nível global, no Simpósio Internacional sobre o Poder Marítimo promovido pela marinha norte-americana. ${ }^{135}$

O Simpósio Naval do Oceano Índico é outra iniciativa voltada para a segurança marítima. Ele foi promovido pela Índia, em 2008, como um fórum de debates e de geração e propagação de informações sobre temas marítimos entre os países costeiros da região. Seus propósitos são: promover uma visão regional dos temas marítimos, estabelecer estratégias comuns e incrementar a cooperação, fortalecer as capacidades das forças navais e a interoperabilidade "em termos de doutrina, procedimentos, organização e logística", para atuar eficazmente nos casos de assistência humanitária e de desastres na região do Oceano Índico. Atualmente, conta com 35 Estados-membros, e vem expandindo sua institucionalização através de reuniões periódicas e com a aprovação de uma "Carta de Negócios" que normatiza o seu funcionamento. ${ }^{136}$

Os países costeiros do Mar Negro, em 2001, durante uma das reuniões periódicas dos chefes das suas marinhas, decidiram, por iniciativa da Turquia, criar o Grupo-Tarefa Naval para Cooperação no Mar Negro, com o propósito de "promover a paz e a estabilidade na área, incrementando a cooperação e as boas relações entre os Estados-membros”. Participam desse Grupo: Bulgária, Geórgia, Romênia, Rússia, Turquia e Ucrânia. Além dos resultados positivos em termos de cooperação no campo do terrorismo, controle de armas de destruição em massa, tráfego ilícito etc., esse mecanismo tem contribuído para o diálogo entre os países da região, inclusive com vários encontros entre representantes dos ministérios das Relações Exteriores e das marinhas. ${ }^{137}$

\footnotetext{
${ }^{135}$ Disponível em: http://www.marina.difesa.it/attivita/coopint/rss_ita/ita_2010/Documents/RSS2010_executive_sum mary.pdf. Acesso em:08 nov.2013.

${ }^{136}$ Disponível em: http://ions.gov.in/?q=about_ions. Acesso em: 29 out.2013.

${ }^{137}$ Disponível em: http://www.mfa.gov.tr/blackseafor.en.mfa. Acesso em: 08 nov.2013.
} 
Além disso, em 2002, após um longo período de negociações, esses seis países assinaram um acordo sobre medidas de confiança e criação de segurança mútua no campo naval para o mar Negro. O documento ressalta a importância daquela área marítima para a promoção da paz e segurança, enfatiza a especificidade da mesma e elenca inúmeros aspectos de segurança e defesa que os Estados devem implementar. Por fim, estabelece reuniões periódicas para acompanhamento dos resultados e trocas de informações. ${ }^{138}$

\section{2 .2}

\section{Ensino, pesquisa, treinamento e exercícios militares}

Além dos mecanismos, a institucionalização da diplomacia de defesa se estende para as áreas de estudo, ensino e treinamento para civis e militares na área da segurança e da defesa. Normalmente, essa é a prática social mais comum entre os Estados, que, através das instituições militares, promovem o intercâmbio de pessoal ou oferecem vagas para alunos de outros países. Face ao vulto dessas atividades e o número de instituições ao redor do mundo que participam dessa prática, neste item serão exemplificadas apenas algumas instituições constituídas especificamente com o caráter de fórum de ensino, pesquisa e debates multilaterais.

Os EUA têm um papel de destaque nesse campo. Em 2012, cerca de 108.000 estudantes de 160 países participaram dos cursos e treinamentos proporcionados pelo Departamento de Defesa, ${ }^{139}$ que é responsável por inúmeros centros desse tipo, sendo cinco deles voltados para os estudos regionais de segurança. O Centro Europeu George C. Marshall para Estudos de Segurança, inaugurado em 1993, é uma parceria bilateral entre os EUA e a Alemanha. Localizado neste país, em Garmisch-Partenkirchen, realiza uma variedade de programas com foco acadêmico, incluindo diversos cursos ou trabalhos de resolução de problemas, envolvendo oficiais de mais de 110 países. Ele foi

\footnotetext{
${ }^{138}$ Disponível em: https://disarmamentlibrary.un.org/UNODA/Library.nsf/1eba87b71da2aad685256bdb0074cffe/77aafb671ccf94d48525 6bde00737e07/\$FILE/ga57.82.pdf. Acesso em: 08 nov.2013.

${ }^{139}$ Alguns programas são conduzidos com recursos do Departamento de Estado. Disponível em: http://www.state.gov/documents/organization/213444.pdf. Acesso em: 14 nov.2013.
} 
constituído fundamentado na ideia da necessidade de influenciar o desenvolvimento dos temas de segurança e defesa na interação com as novas democracias que estavam sendo estabelecidas após o fim da Guerra Fria. A sua missão é contribuir para a segurança, por meio do avanço da cooperação entre instituições e nações da América do Norte, Europa e Eurásia, e das relações democráticas no campo da defesa. Está organizacionalmente subordinado ao Comando Militar dos EUA na Europa e tem seu corpo docente e sua equipe administrativa constituídos por representantes de 10 países. ${ }^{140}$

O Centro da Ásia-Pacífico para Estudos de Segurança foi inaugurado em 1995, com sede no Havaí. Ele foi estabelecido fundamentado na ideia da necessidade de "incrementar as relações entre o Comando Militar dos EUA no Pacífico com as Forças Armadas daquela região, através de uma abordagem multilateral sobre os temas de segurança regional e global". Para atingir esse propósito, é definido como uma instituição acadêmica, que também favorece as conexões pessoais e institucionais, gerando "capacidades e comunidades de interesse para avançar a segurança na região Ásia-Pacífico". Nesse contexto, além dos cursos, seminários e outras atividades desenvolvidas por um corpo docente formado por militares e professores civis, também, incentiva a criação de associações de ex-alunos em diversos países. ${ }^{141}$

As outras três instituições estão sediadas em Washington. O Centro de Estudos William J. Perry para a Defesa do Hemisfério foi constituído como um desdobramento das reuniões de ministros de Defesa das Américas, fundamentado na ideia da necessidade de se preparar especialistas civis nos temas militares e de segurança e defesa. Ativado em 1997, ele conduz atividades acadêmicas para civis e militares da região, com o propósito de incrementar "a cooperação regional, a confiança e o entendimento mútuo." 142

O Centro de Estudos Estratégicos Africanos, estabelecido em 1999, busca fortalecer a capacidade estratégica dos países desse continente para "resolver problemas de segurança e incrementar a democracia, os direitos humanos e as relações civis-militares." Atualmente, está instalado na Universidade Nacional de

\footnotetext{
140 Disponível em: http://www.marshallcenter.org/mcpublicweb/en/nav-main-home-en/nav-mainhome-about.html. Acesso em: 13 nov.2013.

${ }^{141}$ Disponível em: http://www.apcss.org. Acesso em: 13 nov.2013.

142 Disponível em: https://chdsnet.org/organization/william-j-perry-center-hemispheric-defensestudies. Acesso em: 19nov. 2013.
} 
Defesa (UND) e possui escritórios regionais em Addis Abba, Etiópia e Dakar, no Senegal. Nos seus cursos, seminários etc. já passaram cerca de 4500 civis e militares africanos e de outras regiões. O Centro promove, ainda, a formação de uma "comunidade global" de profissionais que participaram dos seus diversos programas. ${ }^{143}$

Finalmente, o Centro de Estudos Estratégicos do Oriente Próximo e do Sul da Ásia, inaugurado em 2001, que também se situa junto à UND, em Washington. Da mesma forma que os seus congêneres, ele busca, através da interação acadêmica, estudar e debater temas relacionados com a segurança e a defesa, em um ambiente que favoreça as relações pessoais e institucionais, a fim de contribuir para o fomento do diálogo e da cooperação regional nas regiões que compõem o seu título. Desde a sua criação, mais de 3000 civis e militares de alto nível participaram das suas atividades. ${ }^{144}$

Em 2001, foi criado o Instituto de Cooperação de Segurança do Hemisfério Ocidental, localizado em Forte Benning, nos EUA, sob a gestão do Exército norte-americano, como sucessor da Escola das Américas. Tem, como missão, prover educação e treinamento para civis, forças policiais e militares de Estados da região, "dentro do contexto dos princípios democráticos estabelecidos na Carta da Organização dos Estados Americanos”. Seu corpo docente inclui, além dos professores norte-americanos, civis e militares de vários países desse hemisfério. Desde sua criação, cerca de 16.000 estudantes passaram pelo Instituto. ${ }^{145}$

A Academia Interamericana das Forças Aéreas é outra instituição constituída pelos norte-americanos baseada na ideia do fortalecimento da “segurança interamericana”. A sua criação, sugerida pelo então Ministro da Aeronáutica peruano aos seus colegas norte-americanos, remonta o ano de 1943. ${ }^{146}$ Sob a responsabilidade da Força Aérea dos EUA, a Academia, localizada no Texas, promove cerca de 30 cursos técnicos e acadêmicos, formando mais de

\footnotetext{
${ }^{143}$ Disponível em: http://africacenter.org/about. Acesso em 13 nov.2013.

${ }^{144}$ Disponível em: http://nesa-center.org/mission-vision. Acesso em: 13 nov.2013.

145 Disponível em: http://www.benning.army.mil/tenant/whinsec/history.html. Acesso em:12 nov.2013

${ }^{146}$ Disponível em: http://www.37trw.af.mil/shared/media/document/AFD-121221-016.pdf. Acesso em: 13 nov.2013.
} 
800 estudantes por ano, e em seus mais de 60 anos de existência, orgulha-se de ter "constituído uma fraternidade internacional de aviadores." 147

Em 1962 foi inaugurado o Colégio Interamericano de Defesa, localizado em Washington, e associado à JID. Seus corpos docente e discente são compostos de civis e militares de diversos países das Américas, e seu curso anual está voltado para os temas de segurança e defesa no nível interamericano e global. Dentre seus objetivos, encontra-se a promoção da confiança, dos direitos humanos e do conhecimento dos costumes e tradições dos EUA. O foco dos seus trabalhos são as ameaças à segurança da região, as operações de paz, a negociação e resolução de conflitos e as situações de grandes desastres. Desde a sua criação, cerca de 2000 estudantes de mais de 20 países passaram pelo Colégio, sendo que cerca de $40 \%$ deles se tornaram oficiais-generais ou alcançaram nível equivalente no meio civil. ${ }^{148}$

Graças, principalmente, à crença do General Dwight D. Eisenhower da necessidade de uma instituição internacional que formasse líderes, nasceu o Colégio de Defesa da OTAN. Inaugurado em Paris em 1951 e, posteriormente, transferido para Roma, quando a França saiu da Organização, prepara militares e civis, inclusive diplomatas, para o desempenho de "importantes cargos" naquela Aliança e em outras organizações multinacionais, conduz pesquisas e estudos nos temas político-militares, desenvolve um programa de relacionamento com outras instituições existentes nesse campo e contribui para a eficácia e coesão da OTAN. ${ }^{149}$ Nos seus mais de 60 anos, a instituição formou cerca de 7000 alunos dos Estados-membros e de outros países, inclusive daqueles que participam da Parceria para a Paz, daqueles do Diálogo do Mediterrâneo e de outros da Iniciativa de Cooperação de Istambul. ${ }^{150}$ Além do Colégio, a OTAN criou, ainda, uma comunidade de ensino, pesquisa e treinamento, que envolve 24 Centros de Ensino e Treinamento da Parceria para a Paz, distribuídos por várias regiões do

\footnotetext{
147 Disponível em: http://www.southcom.mil/newsroom/Pages/New-Inter-American-Air-ForcesAcademy-building-opens-at-Lackland.aspx. Acesso em: 13 nov.2013.

${ }^{148}$ Disponível em: http://www.colegio-id.org/overview.shtml. Acesso em: 13 nov.2013.

149 Disponível em: http://www.ndc.nato.int/about/statement.php?icode=23. Acesso em: 13 nov.2013.

${ }^{150}$ Disponível em: http://www.ndc.nato.int/. Acesso em: 13 nov.2013.
} 
mundo, que "promove transparência e entendimento mútuo, contribuindo para a segurança, a estabilidade e a paz". ${ }^{151}$

O Colégio de Defesa do Báltico, fundado em 1998, é uma instituição de ensino militar administrado pela Estônia, Letônia e Lituânia, com a missão de prover educação no âmbito da segurança e da defesa a militares e civis dos três países. Os currículos dos seus cursos são adaptados para harmonizarem-se com as ideias e os conceitos defendidos pela OTAN. O Colégio tem se constituído em um fórum para debates sobre o Báltico e sobre a região Euro-Atlântica. ${ }^{152}$

No âmbito de preparação de forças de paz, há algumas instituições regionais espalhadas pelo mundo. No Canadá, existe o Centro de Treinamento de Apoio à Paz, de caráter multinacional, formalmente estabelecido em 2000, que prepara cerca de 1000 civis e militares por ano para atuar nesse tipo de operação, inclusive em atividades relacionadas à reconstrução e ao fortalecimento do sistema de segurança estatal dos países atendidos. ${ }^{153}$

A diplomacia de defesa tem ensejado, também, uma grande quantidade de práticas relacionadas às operações e exercícios multinacionais ou bilaterais, que se destinam a diversos fins, tais como defesa, manutenção da paz, humanitário, antipirataria etc. Os exercícios, normalmente, visam o treinamento para conduzir operações militares. Além disso, possuem o propósito maior de incrementar a amizade e a cooperação entre as Forças Armadas contra as ameaças compartilhadas à segurança regional ou global.

Esta é uma prática bastante disseminada entre os Estados, principalmente, em termos regionais. Como exemplos desse tipo de interação pode-se citar a Rússia, com a OTAN, Índia, Cazaquistão, Noruega, Ucrânia, Grécia etc. ${ }^{154}$ A China, com os EUA, Paquistão, Índia, Mongólia etc. A África do Sul, com a Alemanha, Brasil, EUA etc. ${ }^{155}$ O Brasil, por sua vez, com os países das

151 Disponível em: http://www.nps.edu/About/USPTC/PfP/PfPCenters.html. Acesso em: 14 nov.2013.

${ }^{152}$ Disponível em:

http://www.mod.gov.lv/Par_aizsardzibas_nozari/Politikas_istenosana/Baltijas_valstu_milit_sadarb iba/Baltdefcol.aspx.e http://www.bdcol.ee/?id=45.

Acesso em: 06 nov.2013.

${ }^{153}$ Disponível em: http://www.forces.gc.ca/en/training-establishments/peace-support-index.page. Acesso em: 13 nov.2013.

${ }^{154}$ Para uma descrição dos exercícios, ver: http://eng.mil.ru/en/mission/practice/all.htm. Acesso em: 14 nov.2013.

155 Para uma descrição dos exercícios, ver: http://www.dod.mil.za/operations/international/exercises.htm. Acesso em: 14 nov.2013. 
Américas, ${ }^{156}$ OTAN, ${ }^{157}$ Índia e África do Sul, no contexto do mecanismo Índia, Brasil e África do Sul (IBAS) ${ }^{158}$ e, bilateralmente, com Venezuela, Bolívia, Paraguai etc. ${ }^{159}$ Muitas dessas práticas sociais estão institucionalizadas e se repetem periodicamente, recebendo, comumente, uma denominação que as identifica. Algumas delas serão exemplificadas a seguir, principalmente aquelas promovidas pelos comandos militares regionais norte-americanos.

A UNITAS, realizada anualmente desde 1959, é o mais antigo exercício multilateral que a marinha dos EUA promove, através do Comando Militar dos EUA para o Sul, no Pacífico, no Atlântico e no Caribe, com as suas congêneres do Hemisfério e com a participação eventual de países da OTAN. Seu propósito é desenvolver a cooperação multilateral, "manter a familiaridade institucional e a amizade" e promover a interoperabilidade. Embora tenha sido criada no contexto global do ambiente estratégico da Guerra Fria, ela se manteve e se adaptou para o novo cenário da promoção da segurança marítima regional. ${ }^{160}$

O Comando Militar dos EUA no Pacífico realiza, periodicamente, uma série de exercícios. A "Borda do Pacífico", realizada, a partir de 1971, a cada dois anos, é o maior exercício marítimo multinacional do mundo. Seu propósito é incrementar a cooperação e a "projeção de poder e o controle de área marítima para garantir a segurança dos oceanos”. Em 2012, dele participaram 22 países, sendo 11 deles com pessoal, e os demais, inclusive a Rússia, com meios navais e aeronavais. ${ }^{161}$ Em 2014, pela primeira vez, contará com a participação da China. $^{162}$

Esse Comando realiza, ainda, no âmbito bilateral, com o propósito de garantir a interoperabilidade e estreitar a cooperação no campo naval, os seguintes

156 A Força Aérea Brasileira (FAB) desenvolve, periodicamente, o Exercício Cruzeiro do Sul (CRUZEX), que é um exercício aéreo multinacional, com o objetivo de preparar as forças envolvidas para o combate aéreo e "desenvolver a cooperação e o bom relacionamento entre elas". Para maiores detalhes, ver: http://www.cruzex.aer.mil.br/index.php/a-operacao/descricao. Acesso em: 14 nov.2013.

157 Disponível em: http://www.mar.mil.br/hotsites/nomar/atuais/794/794.pdf. Acesso em: 14 nov.2013.

${ }^{158}$ Mecanismo político que envolve Índia, Brasil e África do Sul. Disponível em: http://www.mar.mil.br/menu_v/operacoes_navais/OperacaoIBISAMAR.htm. Acesso em 14 nov.2013.

${ }^{159}$ Para os exercícios desenvolvidos pela Força Aérea Brasileira, ver: http://www.fab.mil.br/portal/capa/index.php?page=operacoes_aereas. Acesso em: 14 nov.2013

160 Disponível em: http://www.southcom.mil/newsroom/Pages/UNITAS-2013.aspx. Acesso em: 13 nov. 2013.

${ }_{161}^{1}$ Disponível em: http://www.cpf.navy.mil/rimpac/2012/about/. Acesso em: 13 nov.2013.

162 Disponível em: http://www.china.org.cn/world/2013-09/21/content_30086635.htm. Acesso em: 19 nov.2013. 
exercícios: o "Keen Sword/Keen Edge”, com o Japão; o Balikatan”, com as Filipinas, o "Cobra Gold", com a Tailândia, e o "Talisman Saber", com a Austrália. ${ }^{163}$

O Comando Militar dos EUA para a Europa, por sua vez, promove anualmente, desde 1995, o exercício "Combined Endeavour”, com os membros da OTAN, países que participam da Parceria para a Paz e outros "parceiros estratégicos". O evento é considerado o "maior exercício multinacional de interoperabilidade de comando, controle, comunicação e computadores (C4)". As experiências adquiridas têm sido consolidadas em normas, que contribuem para a realização, inclusive, de operações de paz e humanitárias. ${ }^{164}$

Alguns exercícios se destinam a um fim específico, como é o caso do "Panamax", originalmente sugerido pelo Chile, e promovido pelo Comando Militar dos EUA para o Sul, desde 2003. O seu propósito é treinar uma força multinacional para garantir a defesa do canal do Panamá, "dentro de um mandato da ONU”, e incentivar os países participantes da Iniciativa de Segurança contra a Proliferação ${ }^{165}$ a desenvolverem as ações estabelecidas nesse mecanismo. Dele participam países das Américas, podendo, entretanto, haver algum país europeu, normalmente, membro da OTAN. ${ }^{166}$

Outras operações visam ações humanitárias para construção de infraestrutura, atendimento médico-odontológico para a população, contribuição para o treinamento das Forças Armadas para operações civis-militares e para geração de uma imagem positiva nos países atendidos. Anualmente, a partir de 1980, o Comando Militar dos EUA para o Sul promove o exercício multinacional, denominado "Além do Horizonte/Novo Horizonte", com a participação de agências governamentais e organizações não-governamentais, normalmente, para atender populações dos países da América Central e do Caribe. Além do apoio médico, são realizadas construções, reparos de engenharia etc. ${ }^{167}$

\footnotetext{
${ }^{163}$ Disponível em: http://www.pacom.mil/about-uspacom/exercises-engagements.shtml. Acesso em: 14 nov. 2013.

${ }_{164}$ Disponível em: http://www.eucom.mil/key-activities/exercises-and-operations/exercisecombined-endeavor. Acesso em: 13 nov.2013.

${ }^{165}$ A Iniciativa de Segurança contra a Proliferação, cuja sigla em inglês é PSI, é um mecanismo multilateral capitaneado pelos EUA, que visa contribuir para a não-proliferação de "armas de destruição em massa", seus sistemas de transporte e materiais com característica dual. Para uma descrição do mecanismo, ver: http://www.state.gov/t/isn/c10390.htm. Acesso em: 23 nov.2013.

${ }^{166}$ Disponível em: http://www.socso.southcom.mil/panamax.aspx. Acesso em: 14 nov.2013.

167 Disponível em: http://www.southcom.mil/newsroom/Pages/Beyond-the-Horizon--NewHorizons-2013.aspx. Acesso em: 14 nov.2013.
} 
No Pacífico, o tsunami que atingiu em 2004 vários países do Sudeste Asiático, ensejou a operação humanitária "Assistência Unificada", promovida pelo Comando Militar dos EUA para o Pacífico, e que, em 2006, evoluiu para se tornar multinacional, com a participação de outras agências e ONGs. A partir de 2008, ela passou a ser denominada "Parceria para o Pacífico", mantendo seu caráter de ajuda médico-odontológico às populações carentes, e de apoio na construção de infraestrutura aos países assistidos, contribuindo para incrementar a cooperação entre estes e as entidade participantes e "assegurar que a comunidade internacional esteja mais bem preparada em casos de desastres". 168

Mecanismos regionais como a ASEAN também executam, periodicamente, exercícios militares para atuação nas situações de desastres naturais, contra-terrorismo e segurança marítima. Em 2013, foi realizado um exercício militar voltado para catástrofes, envolvendo os Estados-membros e mais oito países: Austrália, China, Índia, Japão, Nova Zelândia, Rússia, República da Coréia e EUA. ${ }^{169}$ Outro exemplo, é o exercício multinacional de contramedidas de minagem realizado pelos países participantes do Simpósio Naval do Pacífico Ocidental, do qual, em 2011, participaram os seguintes países: Austrália, França, Índia, Indonésia, Malásia, Nova Zelândia, República da Coréia, Singapura, Tailândia, USA e Vietnam e, como observadores a China e a Suécia. ${ }^{170}$

Mecanismos inter-regionais, como, por exemplo, a CPLP e o IBAS, também promovem exercícios militares. O primeiro realiza a operação Felino, desde 2000, que busca permitir o treinamento para operações de paz e de assistência humanitária. A partir de então, ele tem sido realizado anualmente, na carta, e, a cada dois anos, no território de Angola, do Brasil ou de Portugal. ${ }^{171} \mathrm{O}$ segundo mecanismo tem realizado a Operação IBSAMAR, que é um exercício

\footnotetext{
168 Até 2012, as operações tinham atendido cerca de 230.000 pacientes, executado serviços veterinários em mais de 33.000 animais e finalizado mais de 140 projetos de engenharia. Disponível em: http://www.cpf.navy.mil/pacific-partnership/2013/history/. Acesso em: 14 nov.2013.

${ }_{169}$ Disponível em: http://eng.mod.gov.cn/Press/2013-05/31/content_4453731.htm. Acesso em:24 out 2013.

${ }^{170}$ Disponível em: mindef.gov.sg/imindef/press_room/official_releases/nr/2011/mar/25mar11_nr/25mar11_fs.html\#. UsV1K_tHIQ1. Acesso em: 02 jan.2014.

${ }^{171}$ Em 2013, o exercício foi realizado no Brasil, com a participação de Angola, Cabo Verde, Moçambique, Portugal, São Tomé e Príncipe e Timor Leste, envolvendo cerca de 1000 militares. Disponível em: http://www.defesa.gov.br/index.php/imprensa/ultimas-noticias/8806-17-09-2013defesa-felino-2013-paises-da-cplp-realizam-exercicio-conjunto-na-costa-brasileira. Acesso em: 26 dez.2013.
} 
compartilhado entre as marinhas da Índia, Brasil e África do Sul, sendo que o último país ainda participa do Exercício ATLASUR, com as marinhas da Argentina, Brasil e Uruguai (A.SUL, 2012-2013, P.104).

\section{3}

\section{Conclusão}

A amplitude e a variedade das práticas sociais e normas relacionadas com o âmbito da Defesa, constituídas no tempo e no espaço, apontam para a disseminação desse fenômeno em escala mundial, envolvendo os Estados e outras entidades que atuam na política internacional. Normalmente, essas práticas se fundamentam em ideias e crenças e em interesses comuns que as sustentam, e que contribuem para a sua reprodução e institucionalização.

Além das interações bilaterais, existe um conjunto de interações multilaterais, algumas constituídas no período da Guerra Fria e, muitas, após o fim do conflito ideológico. Embora a maioria tenha um caráter regional, existem outras com abrangência global ou inter-regional, que se constituem em fóruns de diálogo que possibilitam reunir informações, comunicar e negociar condições de cooperação, acordos, mecanismos e tratados. Em síntese, elas produzem e reproduzem as relações não coercitivas entre os Estados e outras entidades que atuam na política internacional. 


\section{4}

\section{Diplomacia de defesa}

\section{1 \\ Introdução}

Como visto no capítulo anterior, existe um conjunto de práticas sociais não coercitivas relacionadas com o âmbito da Defesa que apontam para um fenômeno de escala mundial. Elas se constituem em diversas formas de interação que produzem e reproduzem as relações não coercitivas entre os Estados e outras entidades que atuam na política internacional.

Esse fenômeno é aqui analisado, fundamentado na discussão conceitual realizada no Capítulo 2, para responder duas questões: se essas práticas sociais constituem um tipo de diplomacia e, caso afirmativo, qual o seu papel na sociedade internacional.

\section{2}

\section{Abordagens teóricas e a diplomacia de defesa}

Como discutido anteriormente, a diplomacia, fundamentada, principalmente, nos conceitos da Escola Inglesa, pode ser definida como uma instituição da sociedade internacional, que se constitui pela reprodução no tempo e no espaço de práticas sociais específicas de agentes oficiais, para construir e reproduzir, por meios pacíficos, as relações entre os Estados e outras entidades que atuam na política internacional.

Essas práticas também tiveram e continuam a ter uma dimensão militar com um papel importante na sociedade internacional, pois, muitas vezes, o acordo, a acomodação, a cooperação ou o conflito podem ser afetados pelas forças militares ou exigir o seu uso. ${ }^{172}$ Muitas delas estão relacionadas com o emprego

\footnotetext{
${ }^{172}$ Sharp (2009) afirma que não se pode negar o papel das armas e da tecnologia na expansão da sociedade europeia de Estados, embora a tradição diplomática do pensamento internacional permita ver em que medida a participação desses instrumentos na consecução das condições que possibilitaram a solução dos conflitos foram resultado de ações diplomáticas.
} 
da força e são estudadas por várias abordagens teóricas, inclusive pela Escola Inglesa, que considera a guerra como uma das instituições daquela sociedade, conforme visto anteriormente. Em face da possibilidade de conflito armado e das suas consequências para os Estados envolvidos e a sociedade internacional, é compreensível que a dimensão militar coercitiva tenha um papel de destaque nos estudos das Relações Internacionais. ${ }^{173} \mathrm{O}$ próprio termo "diplomacia" tem sido associado à coerção e à violência. ${ }^{174}$ Afinal, mesmo após a Guerra Fria, "o uso da força continua sendo uma significativa característica da política mundial" (BAYLIS e WIRTZ, 2006) e "a política externa quase sempre carrega com ela a ameaça implícita do uso da força" (HILL, 2003, P.143).

Essa mesma visão é encontrada em autores que tratam especificamente da diplomacia, que consideram a dimensão militar relacionada, principalmente, com a ameaça ou o emprego da força (BARSTON, 2006). Outros, que consideram a dimensão militar de forma instrumental para a consecução dos objetivos de política externa, até se referem à possibilidade dos meios militares serem usados em estratégias hard ou soft, mas, na sua abordagem, privilegiam, também, a análise, basicamente em relação às possibilidades e constrangimentos da ameaça ou do emprego da força na busca de objetivos de política externa (HILL, 2003). 175

Apesar da importância da dimensão coercitiva, os recursos militares tangíveis e intangíveis possuem uma natureza ambígua, pois, embora sua existência esteja relacionada, principalmente, com a possibilidade de conflito entre os Estados ou com o seu uso em estratégias hard, eles são, normalmente, muito mais usados na dimensão não coercitiva, em diversas atividades, inclusive naquelas relacionadas com a reconstrução de nações ou a segurança e o desenvolvimento ou, apenas, como um modo de manter a conversação na

\footnotetext{
${ }^{173}$ Segundo Aron (1979), o núcleo das relações internacionais são as "relações interestatais", que se manifestam através do diplomata e do soldado, como representantes das coletividades a que pertencem, sendo que o primeiro trata da diplomacia e o segundo da guerra.

${ }^{174}$ Schelling (1966) considera que o potencial militar de um Estado pode ser usado como poder de barganha para influenciar outros Estados. Usado dessa forma, a capacidade para violência seria parte da diplomacia, algo como uma "diplomacia da violência". George (1994) defende a existência de uma "diplomacia coercitiva", no sentido de ameaçar o emprego da força para conseguir que um lado pare de fazer ou desfaça aquilo que fez.

${ }^{175}$ Para demonstrar a possibilidade de uso do "instrumento militar" em política externa, Hill (2003, P.334) cita o exemplo do mecanismo Partnership for Peace, "promovido pela NATO para educar os militares do antigo Pacto de Varsóvia nas visões ocidentais das relações civis-militares e de construção de medidas de confiança mútua".
} 
dimensão militar entre diferentes comunidades políticas independentes e outras entidades que atuam na política internacional, como visto no capítulo anterior.

Assim, o reconhecimento da importância do entendimento da dinâmica coercitiva dos instrumentos de força não pode representar o desconhecimento de uma dimensão diplomática que trata das relações não coercitivas no âmbito da Defesa nas Relações Internacionais. Desta forma, apesar da pouca importância com que essa dimensão é abordada, mesmo alguns dos autores que privilegiam a análise da possibilidade da ameaça ou do uso da violência nas relações internacionais a reconhecem implicitamente. Eles afirmam, como visto no Capítulo 2, que a diplomacia profissional, considerada como aquela que é exercida pelos ministérios das Relações Exteriores ou seus congêneres, embora mantenha um papel central na realização das funções diplomáticas, tem tido dificuldades em manter o controle da condução das relações internacionais. ${ }^{176}$

Como visto anteriormente, a diplomacia tem se tornado mais complexa e abrangente, devido, principalmente, ao incremento da atuação do Estado no âmbito doméstico e ao crescimento da interdependência no âmbito mundial (WATSON, 1982). Assim, tem havido um crescente aumento na participação de diversos atores estatais que produzem e reproduzem práticas consideradas de caráter diplomático. Os ministérios da Defesa são considerados um dos mais ativos nesse campo (HILSMAN, 1971; SIMPSON, 1980; BERRIDGE, 2002) e chegam a ser tidos em algumas situações como um dos rivais dos ministérios das Relações Exteriores (HILL, 2003). ${ }^{177}$

Se, por um lado, existe a literatura acima analisada, na qual alguns autores, reconhecendo a existência da possibilidade de uma diplomacia setorial no âmbito da Defesa, não aprofundam a análise da mesma, por outro lado, existe uma literatura recente que trata das práticas diplomáticas nesse campo, focando nos seus aspectos de cooperação ou de ajuda para incrementar a segurança de outros Estados como uma ferramenta da política externa e de segurança, sem discutir os

\footnotetext{
${ }^{176}$ Alguns desses autores estão preocupados com a questão da coerência em política externa, ante à existência de "diplomacias setoriais" que não são diretamente realizadas pelos ministérios das Relações Exteriores (Hill, 2003).

${ }_{177}$ Segundo Deutsch (1982), nas grandes potências, especialmente nos Estados Unidos, o complexo de segurança nacional, do qual as forças armadas fazem parte, tende a buscar preservação não só por razões econômicas, mas, também, por compensações de natureza psicológica e sociológica, tais como o respeito próprio e a auto-estima, e considerar suas ações como dignas e necessárias. Este complexo constitui um grupo de interesse que busca influenciar a política externa.
} 
processos de institucionalização e internacionalização, exemplificados no capítulo anterior e, normalmente, sem aprofundar a natureza da sua relação com a diplomacia, considerada como prática social, como veremos a seguir.

Cottey e Foster (2004) estudam o fenômeno na perspectiva de uma "nova" diplomacia de defesa que vem sendo implementada a partir dos anos 90, principalmente pelas democracias ocidentais, e que é definida como "o uso cooperativo das Forças Armadas e a infraestrutura relacionada (primariamente, os ministérios da Defesa) como uma ferramenta de política externa e de segurança". Para eles, antes do fim da Guerra-Fria essa atividade era desenvolvida e estudada como "parte da realpolitik, da balança de poder e da busca dos interesses nacionais definidos de forma restrita". Nessa visão, a cooperação no campo da defesa era elemento importante na construção de alianças para o incremento de capacidades militares, como forma de contrabalançar ameaças, manter esferas de influência, apoiar governos amigos no controle interno do Estado e conquistar mercados para a indústria bélica.

Com o fim daquele período, passa a existir a "nova" diplomacia de defesa que ganhou uma dimensão menos voltada para o conflito ideológico que permeou as relações internacionais e que, além do tradicional papel que desempenha na realpolitik, apoiando as Forças Armadas e a segurança de países aliados, é, também, usada como um mecanismo para a construção de um relacionamento cooperativo com antigos inimigos e possíveis adversários. As potências ocidentais, especialmente os Estados Unidos da América (EUA), estariam buscando utilizar a cooperação militar internacional para objetivos de segurança e de política externa mais amplos, com o propósito de difundir um modelo liberal de governança fundamentado, principalmente, na promoção da democracia, no controle civil sobre as Forças Armadas e no incremento da capacidade de participação em forças de paz (COTTEY e FOSTER, 2004).

Em uma visão semelhante, Reveron (2010) considera que existe um novo modelo norte-americano de defesa, denominado assistência de segurança ou cooperação de segurança, diferente daquele praticado sob a lógica da Guerra-Fria, que busca, primordialmente, ajudar os parceiros a se prepararem para manter a estabilidade interna, participarem em operações de paz e manterem a estabilidade regional, atuando contra ameaças, tais como o crime organizado e "atores violentos". Nesse contexto, as Forças Armadas norte-americanas estariam 
mudando "de forças de confrontação para forças de cooperação" e adaptando sua estrutura de comando para a prevenção de conflitos, ao invés de neles atuar, o que contribuiria, também, para melhorar a imagem internacional dos EUA. Evitar o caos gerado pela insegurança seria a melhor maneira de evitar intervenções militares. Assim, "exportar segurança teria se tornado mais importante do que exportar democracia" (REVERON, 2010, P.xi;170). A estrutura do Departamento de Defesa, com os seus comandos militares regionais, atuando nas diversas partes do mundo, facilitaria a realização dessas novas tarefas, que transformariam os militares, além de "guardiães, em construtores e diplomatas". As "capacidades civis" militares estariam, portanto, "sendo usadas em apoio a objetivos diplomáticos e de desenvolvimento" (REVERON, 2010, P.xiii - 3).

Os trabalhos de Cottey e Foster (2004) e de Reveron (2010) são contribuições importantes para ajudar a entender a diplomacia de defesa e a sua importância nas relações internacionais, no entanto, eles a consideram relacionada com o uso cooperativo das Forças Armadas e dos ministério da Defesa, como ferramenta de política externa e de segurança das potências ocidentais, especialmente os EUA. Para estes autores, essa diplomacia vem sendo modificada com o fim do conflito ideológico que permeou o período da Guerra-Fria e novas missões estariam sendo designadas para as Forças Armadas dessas potências. ${ }^{178}$ Neste sentido instrumental, aproximam-se da ideia de Hill quanto ao uso de meios militares como instrumento para compor estratégias de política externa. Assim, embora descrevam diversas ações inerentes à diplomacia de defesa, não se aprofundam em como essas práticas sociais foram sendo institucionalizadas e reproduzidas globalmente no tempo e no espaço. Da mesma forma, ao associarem esta diplomacia tão somente à cooperação ou assistência, eles limitam o seu escopo, que é mais abrangente e envolve outras facetas, principalmente, a discordância e o conflito de ideias.

Além do mais, como afirmado pela Escola Inglesa, na política internacional coexistem elementos da tradição realista, racionalista e universalista. Portanto, um incremento de ações que possam ser enquadradas em uma dessas tradições não significa que exista uma mudança significativa que possa ser

\footnotetext{
${ }^{178}$ Reveron (2010) usa, normalmente, o termo "cooperação de segurança" para designar o conjunto dessas atividades desempenhadas pelas Forças Armadas norte-americanas, embora, algumas vezes, tenha empregado, também, o termo "diplomacia militar" com o mesmo sentido.
} 
considerada como algo "novo". Embora o escopo, as tarefas e os formatos da diplomacia tenham se tornado mais variados e complexos (WATSON, 1982), "as práticas, ideias, normas, regras e etiquetas e funções essenciais da diplomacia como instituição continuam as mesmas" (HOLSTI, 2004, P.12-17).

Assim, não é porque outros temas considerados como das tradições racionalista ou universalista estejam sendo mais implementados na diplomacia de defesa, em determinadas circunstâncias e, normalmente, por algumas potências ocidentais no pós-Guerra Fria, que se pode afirmar que existe uma "nova" diplomacia de defesa. A própria questão dos direitos humanos, que seria um desses "novos" temas, já esteve em destaque na diplomacia de defesa dos EUA, inclusive durante o período do conflito ideológico entre as grandes potências (SIMPSON, 1980). Em relação ao Brasil, por exemplo, a insistência do Governo Carter com esses direitos contribuiu para a denúncia pelo governo do presidente brasileiro Ernesto Geisel, em 1977, do acordo militar entre os dois países (DAVIS, 1996).

Muthanna (2006) é outro autor que se dedica ao assunto, com o intuito de oferecer opções para a Índia quanto às possibilidades e vantagens da cooperação militar como um instrumento de política externa. Em seu trabalho, primeiramente, ele busca definir os componentes dessa cooperação; em seguida, descreve como ela é realizada pelos membros-permanentes do Conselho de Segurança da ONU e por outros Estados e organizações internacionais; e, finalmente, propõe medidas para incrementar esse tipo de cooperação pela Índia.

Na parte conceitual, ele faz uma síntese de como o tema é definido em alguns países, seja como cooperação ou engajamento de defesa, segurança cooperativa ou assistência de segurança, ou diplomacia de defesa etc. Muthanna (2006) afirma que a diferença entre cooperação de defesa e cooperação militar reside no fato do primeiro conceito envolver a participação de agências do estabelecimento de Defesa, inclusive as Forças Armadas, enquanto o segundo, é limitado à cooperação entre estas últimas.

O trabalho de Muthanna (2006) é mais uma importante contribuição para o entendimento do tema, especialmente, por sua pesquisa para descrever como muitos Estados desenvolvem a diplomacia de defesa ou a cooperação de defesa ou militar. No entanto, da mesma forma que os dois primeiros autores analisados anteriormente, ele privilegia a cooperação. Ao tentar definir o conceito de 
diplomacia de defesa, afirma que esta cobriria "todas as ações unilaterais, bilaterais e multilaterais de Defesa para incrementar os objetivos nacionais", que estariam posicionadas em um espectro em que em um dos extremos estaria a ameaça ou o uso da força unilateral e, no outro, a cooperação bilateral e multilateral. Ele exemplifica o primeiro, citando, dentre outras, a operação de invasão do Panamá pelos EUA para derrubar o governo do General Noriega, em 1988, e a mobilização das Forças Armadas indianas e a ameaça da guerra contra o Paquistão para pressionar este país a não apoiar grupos extremistas a realizarem ações terroristas na Índia (MUTHANNA, 2006). A idéia por ele defendida de que a diplomacia de defesa incluiria "todas as ações unilaterais, bilaterais e multilaterais de defesa..." é conceitualmente muito vaga. Além do mais, sua abordagem, ao incluir o uso da força como parte da diplomacia de defesa insere um problema em relação ao conceito de diplomacia, aqui definido como a produção e reprodução, por meios pacíficos, de determinadas práticas sociais, que são mais amplas que a mera cooperação.

A diplomacia de defesa é, também, analisada por Du Plessis (2008) em referência à África do Sul. Segundo ele, o uso dos meios militares para propósitos diplomáticos ou como relações externas de defesa é uma prática comum naquele país, onde a diplomacia de defesa é considerada como a vertente militar da diplomacia. Assim sendo, conceitualmente, nesse país, essa diplomacia não teria o reconhecimento que merece, devido mais ao pouco entendimento "da natureza, do escopo e da sua utilidade", do que à imperfeita relação entre os instrumentos à disposição para a consecução dos objetivos de política externa.

Esse pouco entendimento, segundo Du Plessis, se deve à ambiguidade conceitual, reforçada pela falta de integração entre a política externa e a de defesa e, também, pelo fato da "diplomacia de defesa ficar restrita ao contexto da política militar de defesa, ao invés de ser aprimorada no contexto da política externa" (DU PLESSIS, 2008, P.87). Fundamentado na visão do ministério da Defesa da GrãBretanha sobre o tema (UK,1998), ele considera a diplomacia de defesa como um tipo particular de diplomacia, e defende que ela representaria uma transição do papel das Forças Armadas do âmbito militar para o âmbito político, esmaecendo a separação entre instrumentos militares e diplomáticos. Para ele, os meios militares podem ser usados de três modos: 
"militar, como, por exemplo, o uso coercitivo da força armada; político, como adjunto à diplomacia, por exemplo, em apoio às missões de paz; e diplomático, por exemplo, como diplomacia de defesa" (DU PLESSIS, 2008, p.90).

O artigo de Du Plessis (2008) é importante para ajudar no entendimento do tema, seja pelo desenvolvimento conceitual do que ele considera diplomacia de defesa, para ele uma diplomacia própria (o que é também defendido neste trabalho) e, não, um adjunto militar da diplomacia, seja pela síntese das distinções entre ela e alguns conceitos que são encontrados na literatura, tais como diplomacia militar, coercitiva, de canhoneiras, naval, etc. ${ }^{179}$ No entanto, da mesma forma que os autores acima analisados, ele considera a diplomacia de defesa sem analisar a sua institucionalização e internacionalização, enfatizando, também, o seu papel cooperativo como instrumento de objetivos de política externa e de segurança. Além disso, embora seja útil para sua análise conceituar o emprego dos meios militares por modos (militar, político ou diplomático), essa classificação insere um problema conceitual, porque o uso desses meios terá, sempre, uma conotação política, quando empregado coercitivamente (CLAUSEWITZ, 1989) ou em atividades não coercitivas, pois, em ambos os casos, contribuirá, de alguma maneira, para objetivos maiores estabelecidos pela Política.

Finalmente, segundo Barkawi (2011), em uma abordagem norte-sul, existem categorias clássicas de práticas relacionadas com a diplomacia de defesa, como por exemplo, o uso das Forças Armadas como adjunto da diplomacia na administração das relações entre entidades soberanas, com o intuito de evitar a guerra ou participar da balança de poder. Para ele, outras categorias de práticas, tais como operações da manutenção ou apoio à paz e outras formas de intervenção humanitária, surgiram devido à globalização, à maior atuação da ONU e ao alargamento do conceito de segurança para envolver outras dimensões, além da militar. No seu entendimento, no entanto, a análise da diplomacia de defesa apenas sob a ótica dessas categorias de práticas seria insuficiente e poderia levar a conclusões enganosas, já que elas se dão em uma moldura de hierarquia internacional e de governança sob a égide das grandes potências.

\footnotetext{
${ }^{179}$ Uma das qualidades do artigo de Du Plessis (2008) é que ele busca clarificar o conceito de diplomacia de defesa, contrastando-o com outras ações nas relações internacionais que envolvem o uso de recursos de defesa. No entanto, ele não estabelece uma definição própria de diplomacia de defesa. Esse movimento de análise dessas ações com o intuito de definir aquele conceito será retomado e aprofundado nesta tese para estabelecer uma definição de diplomacia de defesa como prática social e como uma instituição da sociedade internacional.
} 
Assim, para Barkawi (2011), a diplomacia militar poderia ser considerada "menos a administração das relações entre entidades soberanas do que a influência das potências no caráter de Estados e sociedades subordinadas" que, no contexto Norte-Sul, estaria historicamente ligada ao envolvimento dos militares ocidentais na política e organização da força nas antigas colônias. Esse envolvimento estaria além de uma busca de uma melhor governança; e atividades como as forças de paz, controle civil das forças armadas, intervenções "humanitárias" etc. estariam relacionadas com as relações de poder no sistema internacional. Em síntese, a diplomacia de defesa seria um eufemismo que camuflaria a disputa das grandes potências, no tempo e no espaço, para tentar "organizar, moldar e dirigir as Forças Armadas de outros países", com o propósito de contribuir para os seus projetos globais de estabelecimento ou manutenção da ordem (BARKAWI, 2011, P.600).

$\mathrm{O}$ artigo de Barkawi tem o mérito de associar a diplomacia de defesa com uma das mais novas abordagens de Relações Internacionais, a abordagem póscolonial. Embora ele não se proponha a fazê-lo, a sua visão contrasta, em alguns pontos, com as dos autores que consideram que o "engajamento de defesa" é uma forma dos EUA "exportarem segurança”, construindo parcerias que contribuam para que os Estados possam assegurar sua própria estabilidade local ou regional (REVERON, 2010). Apesar dos EUA buscarem avançar seus interesses através da influência que esse tipo de engajamento possa possibilitar, a forma como eles o conduzem difere daquela utilizada antigamente pelas grandes potências, já que o objetivo seria fortalecer as soberanias dos seus parceiros e evitar a instabilidade e o caos que conduzisse para uma intervenção militar. O propósito maior dos EUA seria a estabilidade global e, não, o domínio mundial. Como o sistema das Nações Unidas não estaria se mostrando eficiente para diminuir o déficit de segurança, os EUA estariam sendo "obrigados" a usar os militares para ajudar a reduzi-lo (REVERON, 2010).

Barkawi (2011) considera, ainda, que a principal atividade nas relações entre militares no contexto Norte-Sul é o treinamento. O foco seria treinar os militares para que eles possam atuar mais eficientemente na consecução dos objetivos dos patrocinadores do treinamento, normalmente, as potências ocidentais. Essa abordagem, no entanto, significa limitar a diplomacia de defesa a mero treinamento para um fim específico, quando, na verdade, ela tem um escopo muito maior, e, mesmo que não se possa negar a possibilidade da influência do 
Estado patrocinador no caso de ajuda militar, que é apenas uma das faces dessa diplomacia, o Estado "patrocinado" tem sua própria agenda (STOKER, 2008).

A diplomacia de defesa busca administrar, também, as visões conflitantes que emergem das relações de separação. O foco é como as relações podem ser conduzidas e mantidas no contexto no qual os elementos das tradições de pensamento ocidental (realista, racionalista e universalista) coexistem na política mundial (LITTLE, 2000). Nessa visão, a existência ou não de uma ou mais superpotências e as possíveis demandas das mesmas serão consideradas no contexto das relações de separação e nem sempre serão determinantes nessas relações (SHARP, 2009). Por diversas razões, um Estado, mesmo que seja significativamente mais forte que outro, "nem sempre consegue usar sua força para coagi-lo a se comportar como ele gostaria" (WATSON, 1982, P.34). Finalmente, como visto no capítulo anterior, referente à institucionalização da diplomacia de defesa, as práticas sociais que a constituem estão de tal forma disseminadas entre os Estados, tanto bilateral quanto multilateralmente, que não se pode associá-las tão somente às grandes potências, embora também não se possa deixar de considerar a influência que elas exercem no diálogo diplomático, especialmente os EUA, que é a única superpotência militar.

Em síntese, existe, por um lado, uma literatura fundamentada, basicamente, na Escola Inglesa, que aborda e aprofunda o entendimento da diplomacia como prática social e como uma instituição da sociedade internacional, e que, embora reconhecendo, explicitamente, o papel coercitivo dos recursos militares e a guerra como instituição, não se debruça do mesmo modo nas práticas sociais não coercitivas desses recursos; por outro lado, existe uma literatura recente que define diplomacia de defesa, basicamente, como sinônimo de cooperação no âmbito da Defesa, como uma forma de exportar segurança, ou como um eufemismo para treinar Forças Armadas de "países subordinados" para manter a ordem que interessa às grandes potências, sem analisar sua institucionalização e, normalmente, sem aprofundar sua relação com a diplomacia e com a sociedade internacional. Desta forma, fundamentada na abordagem teórica desenvolvida no capítulo anterior, o próximo item desenvolve uma definição e uma análise mais ampla de diplomacia de defesa constituída como prática social. 


\section{3 \\ Definição de diplomacia de defesa}

A diplomacia é mais abrangente e complexa do que a cooperação ou as relações de poder. Como definido no Capítulo 2, ela é uma instituição da sociedade internacional, que se constitui pela reprodução, no tempo e no espaço, de práticas sociais específicas de agentes oficiais para construir e reproduzir, por meios pacíficos, as relações entre os Estados e outras entidades que atuam na política internacional. Assim, analogamente, o argumento central desta tese considera que a diplomacia de defesa é o conjunto de práticas sociais específicas de agentes oficiais, para construir e reproduzir as relações não coercitivas no âmbito da Defesa entre os Estados e outras entidades que atuam na política internacional. Pela suas características e funções ela pode ser considerada como uma instituição da sociedade internacional, sub instituição da diplomacia, que se constitui pela reprodução no tempo e no espaço dessas práticas.

E quais seriam os principais atores relacionados com a diplomacia de defesa? Os ministérios da Defesa e as Forças Armadas possuem um papel primordial nesse tipo de diplomacia, pois as suas ações se desenvolvem no campo dos recursos tangíveis e intangíveis da estrutura de Defesa dos Estados. Os principais agentes oficiais são, portanto, os civis e militares no âmbito da Defesa. Entretanto, como não é possível estabelecer fronteiras rígidas em um fenômeno tão complexo que envolve temas político-estratégicos, há que se considerar o papel dos ministérios das Relações Exteriores e dos diplomatas, devido à íntima relação da diplomacia de defesa com a política externa e a própria diplomacia e com a necessidade de coordenação que contribua para a coerência na ação diplomática. Esse papel é mais importante no diálogo relacionado com os temas de mais alto-nível da diplomacia de defesa no qual a Política tem uma atuação preponderante, tais como as alianças e parcerias estratégicas, os tratados multilaterais e acordos de Defesa etc. Nesses casos, normalmente, civis e militares do âmbito da Defesa participam junto com representantes do ministério das Relações Exteriores. Outros atores estatais ou entidades com status na política internacional, como, por exemplo, a OTAN e a ONU, também atuam na diplomacia de defesa. 
Alguns elementos da definição de diplomacia de defesa merecem ser esclarecidos e outros, questionados: qual o motivo para se considerar que ela trata de relações não coercitivas no âmbito da Defesa, se os recursos militares, normalmente, estão associados à coerção? e por que seria ela uma instituição da sociedade internacional? O primeiro questionamento será analisado a seguir e a questão relacionada com a instituição será tratada no próximo item.

Apesar da importância da dimensão coercitiva, os recursos militares humanos e materiais possuem uma natureza ambígua. Embora sua existência esteja relacionada, principalmente, com a ameaça e o emprego da força entre os Estados, eles possuem outro papel fundamental de natureza não coercitiva, inclusive relacionado com a segurança e o desenvolvimento, como veremos mais adiante. ${ }^{180}$ Essa natureza dificulta o estabelecimento de uma nítida fronteira entre as duas dimensões; no entanto, se faz necessário, ainda que precariamente, delimitar a dimensão das práticas sociais não coercitivas no âmbito da Defesa, pois elas encerram em seu bojo a essência da diplomacia como entendida pela Escola Inglesa: um diálogo pacífico entre Estados e outras entidades que atuam na política internacional.

A diplomacia de defesa é um tipo de diplomacia que se caracteriza por seu campo de atuação, aquele relacionado com os recursos tangíveis e intangíveis da Defesa, e por sua natureza não coercitiva. Assim, sua principal característica é a construção e reprodução de relações no âmbito da Defesa entre os Estados e outras entidades que atuam na política internacional que não implicam a ameaça ou no uso da força. Esse paradoxo lhe confere uma identidade singular. Desta forma, analiticamente, torna-se mais fácil visualizar o que a diplomacia de defesa não é; por exemplo, ela não é "diplomacia coercitiva", nem diplomacia de canhoneira, tampouco "diplomacia da violência", ou intervenção militar de qualquer espécie. Também não pode ser confundida com o conceito norteamericano de "outras operações militares que não a guerra", cuja sigla em inglês é

\footnotetext{
${ }^{180}$ Um exemplo do leque de possibilidades de uso dos recursos militares para fins pacíficos, devido à natureza ambígua desses recursos é a inusitada possibilidade de usar um submarino, uma arma de ataque por excelência, para coletar dados oceanográficos (UN, 1993, P.34).
} 
MOOTW, ${ }^{181}$ que, apesar de considerar o uso não coercitivo, inclui o uso coercitivo dos meios militares em tempo de paz.

Basicamente, é semelhante ao que ocorre com o conceito do "uso político das Forças Armadas", ou, mais especificamente, "uso político do Poder Naval", usado por alguns autores para diferenciar o emprego deliberado dessas Forças por autoridades nacionais para alcançar resultados "short of war". ${ }^{182}$ Como afirmado anteriormente, o emprego dos meios militares nas relações internacionais terá, sempre, um propósito político, tanto na guerra como na paz. Além do mais, a maneira pela qual o "uso político" é conceituado, embora contenha práticas não coercitivas, abrange, também, a possibilidade de coerção por meio da ameaça ou do uso limitado da força, o que não se harmoniza com o conceito defendido nesta tese para a diplomacia de defesa.

Nessa mesma linha, a diplomacia de defesa não pode ser confundida com diplomacia naval, pois esta, apesar de também considerar o uso não coercitivo, engloba práticas coercitivas, utilizando meios navais e aeronavais em tempo de paz $^{183}$ (DU PLESSIS, 2008). Da mesma forma, embora a diplomacia de defesa inclua a cooperação militar ou "de segurança", ela é mais abrangente que esta. A administração das relações de separação na dimensão da defesa implica, também, em discordâncias, conflitos de ideias ou, simplesmente, em manutenção da conversa diplomática.

A diplomacia de defesa também não se limita às questões relacionadas com o desenvolvimento militar dos países, e tentar explicá-la atendo-se, apenas, ao âmbito técnico-militar, como uma forma de acompanhar o desenvolvimento militar de possíveis oponentes, nem sempre é tarefa fácil, pois, por exemplo, em

\footnotetext{
${ }^{181} \mathrm{O}$ conceito de Military Operations Other Than War ( MOOTH) abrange, também, atividades de combate, que podem ser usadas até mesmo junto com atividades não coercitivas (USA-JCS, 1995).

${ }^{182}$ Para Blechman e Kaplan (1978), o "uso político das Forças Armadas " ocorre quando as autoridades nacionais as usam por meio de "ações físicas", como parte de uma tentativa deliberada de "influenciar ou estar preparado para influenciar comportamentos específicos de indivíduos de outros Estados, sem se engajar em uma competição contínua de violência." Ao estabelecerem as operações que esse conceito comportaria, os autores mesclam ações não coercitivas e coercitivas. A partir desse conceito, Meernick (2004) desenvolve sua própria definição de uso político das Forças Armadas: " são atividades que buscam influenciar adversários para evitar situações que conduzam a um conflito armado ou à amigos para influenciar o seu comportamento em proveito próprio ", mantendo, no entanto, a mescla de ações coercitivas e não coercitivas. Alguns exemplos desse uso citados pelo autor: a quarentena naval imposta à Cuba durante a Crise dos Mísseis, as invasões de Granada e do Panamá pelos EUA etc.

${ }^{183}$ Para uma síntese do conceito de diplomacia naval desenvolvido por vários autores, ver: David Rowlands "Decided Preponderance at Sea". Naval Diplomacy in Strategic Thought. Naval War College Review. Autumn 2012, Vol. 65, No. 4. PP.89-105.
} 
2011, os EUA possuíam adidos de defesa em 34 países da África, apesar da pouca expressão do poderio militar dos mesmos (PLOCH, 2011, P.8).

Finalmente, ela é mais abrangente que as relações militares, normalmente denominada de diplomacia militar, que pode ser definida como o conjunto de práticas sociais específicas de agentes oficiais para administrar as relações não coercitivas no âmbito militar entre os Estados e outras entidades que atuam na política internacional. A diplomacia de defesa envolve um conjunto de aspectos e tarefas não relacionados especificamente com questões técnico-militares, tratando de temas políticos estratégicos e, muitas vezes, daqueles relacionados com a ajuda humanitária e ao desenvolvimento. Assim sendo, a diplomacia de defesa incorpora, também, uma dimensão de natureza não essencialmente militar relacionada com a segurança.

Como visto no capítulo anterior, os agentes civis e militares do âmbito dos ministérios da Defesa participam de negociações e implementação de acordos e de mecanismos relacionados com temas de segurança e defesa e, muitas vezes, sua atuação extrapola o caráter meramente militar, para enveredar nos processos políticos, econômicos e sociais muito próximo da abordagem dos diplomatas. ${ }^{184} \mathrm{~A}$ dimensão da defesa se tornou um importante instrumento de negociação, tanto bilateral quanto multilateral, na cena internacional e "o estabelecimento militar tem se tornado uma instituição social complexa, com relações de negociação com outras sociedades, inclusive com o uso da assistência militar para fortalecer valores democráticos em países em desenvolvimento" (SIMPSON, 1980, P. 4144).

Apesar da diferença conceitual acima descrita, na qual o campo militar é apenas um componente da Defesa, os termos "diplomacia militar" e, posteriormente, "diplomacia de defesa" vêm sendo utilizados indistintamente para caracterizar a dimensão das relações no âmbito da Defesa entre Estados e a evolução desse tipo de interação em diversos aspectos, tanto entre as Forças

\footnotetext{
${ }^{184}$ O termo " Defesa" acabou sendo incorporado na designação desses ministérios, na medida em que as instituições militares foram evoluindo para a centralização. De modo geral, os ministérios militares foram tendo sua denominação modificada para "Ministérios da Guerra". Logo antes da II Guerra Mundial e, principalmente, com a proibição da guerra na Carta da ONU, esse título foi sendo alterado para ministérios da Defesa, o que, de certa forma, "contribuiu para legitimar o uso da força no mundo ocidental" (BARKAWI, 2011, P.597). Nos EUA, por exemplo, o Departamento da Guerra foi criado em 1789. Em 1949, as Forças Armadas foram unificadas sob o controle do Departamento de Defesa. Disponível em: http://www.defense.gov/about/. Acesso em 11jul.2012.
} 
Armadas quanto entre os ministérios da Defesa. ${ }^{185}$ O termo "diplomacia militar" foi preponderante até o término da Guerra-Fria, tendo sido utilizado por alguns autores como sinônimo de relações militares entre países, significando a cooperação no campo militar (DAVIS, 1996). A denominação "diplomacia de defesa" passou a ser usada, principalmente, após a Guerra-Fria, normalmente relacionada com a ideia já analisada de uma "nova" diplomacia.

Nos EUA, alguns autores denominam esse tipo de interação de "cooperação ou assistência de segurança", buscando associá-lo ao conceito mais amplo de segurança e, também, à mudança no cenário internacional com o término do conflito ideológico entre as potências (REVERON, 2010). A mudança da estratégia norte-americana com o fim da Guerra-Fria, priorizando o engajamento e a disseminação da democracia, influenciou o incremento da cooperação militar, como forma de contribuir para a consecução dos objetivos da Estratégia de Segurança Nacional e para a projeção da influência dos EUA. A diplomacia de defesa foi definida como um componente do "engajamento de defesa", e as interações militares que incluem os programas de cooperação sustentados com fundos do Departamento de Defesa e de Estado, seriam o outro (COPPE, 1996).

$\mathrm{Na}$ Índia, a diplomacia de defesa é definida como " as ações realizadas através das visitas de alto-nível no âmbito da Defesa e dos diálogos relacionados com os desafios `a segurança..."(MUTHANNA, 2006, p.2). Na França, ela é conceituada oficialmente como "a participação das Forças Armadas em ações da diplomacia francesa" (COUTAU-BÉGARIE, 2010).

A denominação de diplomacia de defesa, como um termo oficial, vai se consolidar em 1998, quando, no livro branco de Defesa do Reino Unido, ela é incorporada como uma nova missão para as Forças Armadas, que contribui para os objetivos de política externa, ajudando na promoção da segurança e confiança entre as Forças Armadas europeias e, particularmente, apoiando o desenvolvimento de modernas e democráticas Forças Armadas na Europa Central

\footnotetext{
185 O termo "diplomacia militar" foi empregado por Vagts (1956) de maneira mais restrita para caracterizar a "militarização" da diplomacia nos Bálcãs, quando embaixadores de vários países eram militares e a participação deles junto com outros adidos militares teria favorecido o conflito armado. Simpson apud Berridge (2002) usa esse termo em um sentido mais amplo, para além do conceito de uma diplomacia entre instituições militares de diferentes países, no seu livro, publicado em 1967, sobre a anatomia do Departamento de Estado.
} 
e Oriental. ${ }^{186}$ Mais tarde, ela passou a ser considerada na estratégia, promulgada conjuntamente entre a Defesa e as Relações Exteriores, como parte do engajamento internacional de defesa, definido como o uso dos recursos de Defesa em atividades de não combate, a fim de garantir a influência da Grã-Bretanha (UK, 2013).

Em síntese, o conceito de diplomacia de defesa tem diversas interpretações, inclusive quanto às práticas sociais que estariam por ele englobadas. Embora seja impossível estabelecer um conceito sem ambiguidades e contestações, a definição de diplomacia de defesa defendida nesta tese, associando-a à administração das relações não coercitivas no âmbito da Defesa, contribui para amenizar as dificuldades provocadas pelas inúmeras denominações que tratam dessa prática social. Além do mais, permite relacioná-la ao conceito de diplomacia como instituição, sob a ótica da Escola Inglesa. E a tese se volta a esse tema, no próximo item, para responder por que neste trabalho se argumenta que a diplomacia de defesa é uma instituição da sociedade internacional, sub-instituição da diplomacia.

\section{4}

\section{A diplomacia de defesa como uma instituição da sociedade internacional}

Como visto na discussão conceitual, Bull (1995), ao tratar das instituições, enfatiza a importância das práticas, normas e regras, e deixa implícito o valor das ideias. Holsti (2004), fundamentado na visão de Bull (1995), estabelece três critérios para a existência de uma instituição: padrões de práticas; ideias ou crenças que fundamentam a necessidade das práticas e os objetivos sociais a serem alcançados através delas; e normas, incluindo, regras e etiquetas. Holsti (2004) afirma, também, que uma instituição maior pode ter sub-instituições. Assim, é por meio desses critérios que a diplomacia de defesa será analisada em

\footnotetext{
186 O conceito é definido pelo ministério da Defesa como tendo a missão de: “fornecer forças para atender às atividades variadas realizadas pelo ministério da Defesa para dissipar hostilidade, construir e manter a confiança e ajudar no desenvolvimento da legitimidade democrática das Forças Armadas, contribuindo, assim, de forma significativa para a prevenção e resolução de conflitos" (UK, 1998).
} 
sua condição de instituição da sociedade internacional, sub-instituição da diplomacia.

\subsection{1}

\section{A diplomacia de defesa como instituição}

O capítulo anterior mostrou que os agentes dos Estados e outras entidades que atuam na política internacional produzem e reproduzem um conjunto de práticas sociais no âmbito da Defesa, principalmente, desde o período da Guerra Fria, fundamentado em crenças e normatizado de diversas formas. Esse fenômeno, denominado diplomacia de defesa, apresenta um elevado grau de institucionalização e internacionalização. Embora essa constatação por si só possa fundamentar o argumento da existência de uma instituição, esse item buscará sintetizar como algumas dessas práticas foram se constituindo no passado, associando-as, na medida do possível, ao processo de institucionalização da própria diplomacia.

É difícil estabelecer, sem contestações, as principais etapas do processo pelo qual a diplomacia como uma instituição da sociedade internacional se constituiu. No entanto, como visto no Capítulo 2, o estabelecimento das missões diplomáticas permanentes, a partir do século $\mathrm{XV}$, foi fundamental para que a prática diplomática se tornasse uma atividade contínua entre os Estados. Em 1648, durante o congresso que resultou no Tratado de Westphália, já havia, na Europa, uma rede de embaixadas permanentes, facilitando as relações entre os Estados, mas, também, aumentando a capacidade de se conseguir informações sobre as políticas e os planos dos países onde elas se situavam.

Segundo Holsti (2004), essa rede de embaixadas foi sendo expandida no tempo e no espaço, incrementando um conjunto de práticas ligadas à profissionalização e à especialização, à variedade e quantidade de temas, e à criação de mecanismos para lidar com as relações entre os Estados e as organizações internacionais. Essas práticas se fundamentavam na crença na interdependência entre os Estados e da necessidade da diplomacia ser uma atividade contínua, conforme defendido inicialmente por Richelieu, que reduzisse o atrito entre eles e a possibilidade do conflito armado, deixando para trás a idéia 
comum nos séculos XV e XVI de que ela seria, apenas, uma outra forma de fazer a guerra.

Em relação às normas, elas foram sendo constituídas, fundamentadas, primordialmente, no princípio da soberania. No século XVI, ficou estabelecido que apenas soberanos poderiam enviar embaixadores para outros países e, "essa norma foi tão bem estabelecida que se pode afirmar que ela se tornara um elemento constitutivo da instituição diplomática" (HOLSTI, 2004, P.178). Outras normas foram a imunidade dos embaixadores, a extraterritorialidade da embaixada permanente e aquelas concernentes ao protocolo e à etiqueta. Além dessas práticas, crenças e normas, que Holsti (2004) considera que formam a maior parte da diplomacia como instituição, ele acrescenta, para caracterizar a institucionalização, a rotina e a burocratização, simbolizadas, principalmente, pelas organizações e recursos humanos e financeiros, que sustentam a atividade diplomática.

No tempo e no espaço, foi se consolidando a ideia de que a diplomacia e a dimensão militar caminham juntas: geralmente, tanto os problemas de política externa podem ter implicações militares, quanto os temas de Defesa podem ter consequências diplomáticas atuais ou potenciais (VAGTS, 1956). As próprias características da atividade diplomática implicavam no reconhecimento de que essa dimensão era importante, fosse na busca do conhecimento sobre a capacidade militar de aliados ou de possíveis adversários, ou na cooperação entre comunidades distintas. Muitas vezes, acordos militares andavam lado a lado com acordos políticos e comerciais, reforçando a crença de uma dimensão militar específica na diplomacia e a necessidade de práticas comuns para atingir os objetivos sociais relacionados com essa dimensão.

A própria expansão europeia teve um importante componente militar e as discussões nos séculos XVI e XVII sobre os conflitos armados e o uso do mar, inclusive relacionado com a repressão à pirataria, reconheciam a necessidade de práticas comuns que regulamentassem a codificação das leis da guerra e do uso do mar (HOLSTI, 2004) no aspecto militar-naval. A partir do século XVIII, vários acordos internacionais foram assinados com a participação de negociadores militares, alguns como resultado de alianças políticas, e outros, desenvolvendo esse tipo de aliança pelos compromissos militares assumidos. 
Assim, a diplomacia de defesa foi se constituindo, no tempo e no espaço, como uma atividade contínua, muito interligada ao processo de institucionalização da própria diplomacia. Durante o Absolutismo, a possibilidade de guerras entre os Estados e a necessidade de se administrar as relações entre aliados nos conflitos ou obter informações militares contribuíram para que muitos soldados fossem indicados como embaixadores ou chefiassem missões de caráter diplomático. Essa tendência persistiu em alguns países até a Guerra Fria por vários motivos, dentre os quais a prioridade que os temas de Defesa ganhavam nas políticas externas, a influência que esses embaixadores poderiam ter em países onde os militares tivessem participação expressiva nos governos, ou a necessidade de premiar ou "exilar" oficiais generais cuja presença no país pudesse ser politicamente inconveniente (VAGTS, 1956).

Embora seja difícil separar os campos de atuação desses militares, eles cumpriam, primordialmente, as funções de embaixadores, e seria um exagero considerá-los englobados no conceito de diplomacia de defesa, como definido anteriormente. No entanto, essas indicações mostram que o âmbito da Defesa tinha, muitas vezes, um importante papel nas questões diplomáticas, que exigia um conhecimento específico. Além do mais, a questão da necessidade de se obter informações de caráter político-estratégico, especialmente aquelas relacionadas com a inteligência militar, ${ }^{187}$ era um problema milenar que os Estados buscavam resolver, até mesmo, usando espiões. ${ }^{188}$

Maquiavel já mencionara embaixadores que tinham militares disfarçados nas suas comitivas (HAMILTON e LANGHORNE, 1995). A designação de oficiais de ligação junto a outros Estados já existia no século XVII. Durante as guerras das coalizões desse século e do seguinte, assessores militares estrangeiros foram indicados como oficiais de ligação, com o propósito de ajudar a coordenar os movimentos dos exércitos aliados, representar o embaixador quando este não pudesse estar presente no campo de batalha ou, ainda, verificar como a ajuda financeira dada pelo seu país estava sendo usada (VAGTS , 1967).

\footnotetext{
187 O termo " inteligência", para conceituar esse tipo de informação, passou a ser usado pelos militares a partir do final do século XVII e se disseminou, ganhando maior destaque a partir da Guerra Fria (VAGTS, 1956).

${ }^{188}$ Sun Tzu (1983), no seu livro A Arte da Guerra, escrito há mais de 2500 anos, dedica um capítulo ao emprego de espiões para se conseguir informações do oponente.
} 
Assim, a prática de designar adidos militares se desenvolveu gradualmente, fundamentada na crença na necessidade da administração das relações militares entre os Estados e, também, da obtenção de informações. No entanto, somente no século XIX, a prática de designá-los para servirem nas embaixadas se configurou uma atividade contínua e disseminada entre os Estados, devido, inclusive, aos avanços tecnológicos no âmbito militar e à falta de capacidade do Concerto da Europa em manter a paz entre as grandes potências, o que tornou ainda mais necessário o conhecimento das capacidades tangíveis e intangíveis dos possíveis contendores (SIMPSON, 1980; HAMILTON e LANGHORNE, 1995).

Atualmente, os adidos militares, embora continuem mantendo funções legais relacionadas com a obtenção de dados de inteligência, desempenham um papel muito mais importante como assessores dos embaixadores e como representantes dos ministérios da Defesa e das Forças Armadas nos países ou nas organizações internacionais onde são acreditados. ${ }^{189}$ Se a designação de embaixadores pelos Estados e sua imunidade são consideradas um marco na institucionalização da diplomacia, o mesmo se pode dizer em relação à prática social de designar adidos na diplomacia de defesa. Os adidos militares fazem parte da missão diplomática e possuem as mesmas imunidades, direitos e deveres dos outros membros da mesma, estabelecidos pela Convenção de Viena sobre as Relações Diplomáticas, de 1961.

A normatização da prática da designação de adidos passou a ser complementada, normalmente, pelas Forças Armadas ou o ministério da Defesa onde eles são acreditados, através do estabelecimento de normas para regular suas atividades, que detalham todos os temas relacionados com a função, tais como partida, uso dos uniformes, normas para correspondência, identificação, precedência, privilégios, funções sociais, visitas ou contatos com o ministério ou

\footnotetext{
${ }^{189}$ Em organizações internacionais, como a ONU e algumas de suas agências, militares são rotineiramente designados, por alguns países, para funções de natureza diplomática relacionadas com operações de paz e outros temas de segurança, inclusive desarmamento. No Brasil, por exemplo, já se tornou rotineira a designação de um oficial-general como Conselheiro Militar da Missão Permanente do Brasil junto àquela organização, em Nova Iorque, e de outro, como Conselheiro Militar da Representação do Brasil junto à Conferência do Desarmamento, em Genebra. As atribuições e outros detalhes referentes à essa função podem ser vistas na Portaria Normativa n 2.756, de 19 de Setembro de 2011, do Ministro da Defesa. Disponível em: http://www.jusbrasil.com.br/diarios/30706714/dou-secao-1-20-09-2011-pg-13. Acesso em: 10 jun.2013.
} 
departamento da Defesa ou outras unidades militares, etc. Nos EUA, por exemplo, a embaixada tem que solicitar o credenciamento e o reconhecimento do status do militar indicado para adido do Exército, tanto ao Departamento de Estado, quanto ao Exército norte-americano. Somente após o cumprimento de todas as etapas exigidas, essa instituição militar reconhece o status diplomático individual, assegura os privilégios e oficializa a sua decisão em uma cerimônia específica para credenciamento do adido militar. ${ }^{190}$

A diplomacia de defesa como prática contínua não se limitou, entretanto, à questão dos adidos. A designação de instrutores ou a manutenção de missões militares em outros países foi se disseminando, principalmente, na medida em que o modelo militar de algumas potências europeias foi sendo reconhecido como um sucesso e almejado por outros Estados. Esse fenômeno ocorreu, especialmente, entre o século XVII e o início do século XX, envolvendo vários países, no que alguns autores consideram como a "europeização das forças armadas" (RALSTON, 1990) e se constituiu, normalmente, sob o contexto da disputa diplomática entre as grandes potências da Europa para expandir suas relações comerciais, inclusive com a venda de armamentos, e conseguir aliados até mesmo para formar coalizões. ${ }^{191}$

Muitas missões militares foram enviadas a países fora do continente europeu, constituindo uma prática que simbolizava uma conotação política mais significativa do que a designação de instrutores. O prestígio militar era um dos principais fatores para a escolha do país que ajudaria na formação ou reforma das forças armadas (RESENDE-SANTOS, 2007), embora os vínculos coloniais também fossem um elemento importante (BARKAWI, 2008). Assim, principalmente a França, a Grã-Bretanha, a Prússia e, mais tarde, a Alemanha e, em menor dimensão, a Rússia e a Holanda, separadas ou conjuntamente, tiveram um papel de destaque no envio de instrutores, assessores e missões militares a

\footnotetext{
${ }^{190}$ Para o detalhamento de todas as normas para os adidos estabelecidas pelo Exército norteamericano, ver US Army Foreign Liaison Directorate Military Attaché Guide January 2012.Disponível em: http://www.dami.army.pentagon.mil/offices/damifl/docs/Military\%20Attache\%20Guide\%20Administrative\%20Guidance.pdf. Acesso em: $18 j a n .2013$.

${ }^{191} \mathrm{Na}$ Ásia, acordos militares, muitas vezes junto a acordos comerciais, foram estabelecidos entre potências europeias e Estados indianos entre os séculos XVII e XIX (BULL, 1985).
} 
diversos países, tanto na Europa quanto na Ásia, África e América do Sul (VAGTS,1956; RALSTON,1990; RESENDE-SANTOS, 2007). ${ }^{192}$

O crescimento político e militar dos EUA constituiu um novo ator nesse campo, principalmente, a partir de 1920, quando o Congresso norte-americano autorizou o envio de oficiais da sua marinha como instrutores para ajudar na modernização das Forças Armadas das nações sul-americanas. ${ }^{193}$ Essa prática se estendeu para países de outras regiões, principalmente após a II Guerra Mundial, quando os EUA se tornaram a grande potência militar e o maior ator da diplomacia de defesa no cenário internacional, como visto no capítulo anterior.

O desenvolvimento da diplomacia de defesa ganhou um outro importante elemento com a criação das escolas militares modernas no século XVIII, que institucionalizou a educação militar, como um produto do Iluminismo (VAN CREVELD, 1990). ${ }^{194} \mathrm{~A}$ institucionalização das escolas militares propiciou o aumento das interações entre as Forças Armadas, com a prática de oficiais cursarem em estabelecimentos de ensino militar de outros países, mais tarde estendida para militares de menor graduação, que passaram a atender cursos profissionalizantes. O intercâmbio para estudar ou treinar em determinadas unidades militares de outros Estados foi se consolidando no tempo e no espaço e, atualmente, se tornou rotineiro. A dimensão que esse costume alcançou pode ser aquilatada, por exemplo, pelos cerca de 5000 militares, somente do Caribe e da América do Sul, que anualmente frequentam cursos nos estabelecimentos militares de ensino ou de treinamento nos EUA. ${ }^{195}$

\footnotetext{
${ }^{192} \mathrm{Na}$ época de Napoleão, por exemplo, uma missão militar francesa foi estabelecida na Pérsia, sob o comando do General Gardene, que, além chefiá-la, acumulava o cargo de embaixador. Quando os franceses se retiraram, os britânicos logo tomaram seu lugar. A modernização militar do Japão contou com a ajuda de Grã-Bretanha, França e Alemanha. Na Turquia, França e GrãBretanha dividiram a cooperação militar: os franceses serviram de modelo para o exército e os ingleses, para a marinha turca (VAGTS, 1956: RALSTON, 1990). Os avanços tecnológicos no âmbito militar que ajudaram a expansão europeia também contribuíram para que as elites dominantes na Índia no século XVIII importassem equipamentos e instrutores militares franceses para assessorá-los nos temas relacionados com a Defesa (WATSON, 1985).

${ }^{193}$ Os EUA, em 1914, já tinham enviado um oficial ao Brasil para servir como instrutor na hoje denominada Escola de Guerra Naval e, em 1930, uma missão naval norte-americana foi constituída neste país (DAVIS, 1996).

${ }^{194} \mathrm{Na}$ Prússia, os cursos de altos-estudos para oficiais começaram na época de Frederico, o Grande, e os currículos foram evoluindo e ampliando o número de disciplinas de tal forma que, após a queda de Napoleão, eles passaram a ter uma duração de 3 anos.O currículo de 1823 a 1826, além da parte essencialmente militar, enfatizava disciplinas relacionadas com o estudo de idiomas, história e ciência política (VAN CREVELD, 1990).

${ }^{195}$ Disponível

http://www.southcom.mil/ourmissions/Pages/Multinational\%20Engagement.aspx. Acesso em:22 abril 2013.
} 
A industrialização e a democracia fizeram com que os militares tivessem que adaptar sua organização e seus currículos para abranger um conhecimento tecnológico que impulsionaram práticas organizacionais, como a criação dos estados-maiores, que deram origem a organizações administrativas similares no âmbito civil. Essa tendência evoluiu, principalmente, no século XX, quando novas tarefas reduziram, ainda mais, as diferenças na formação das elites militares e civis, ao incrementarem, na formação dos primeiros, disciplinas mais genéricas, tais como administração, negociação, etc. (JANOWITZ, 1994).

A ambiguidade dos recursos tangíveis e intangíveis do âmbito da Defesa foi sendo constituída, muitas vezes, inter-relacionada com os avanços tecnológicos, que, normalmente, impactavam tanto o meio civil quanto o militar, gerando, muitas vezes, uma relação dual entre eles, possibilitando que tecnologias desenvolvidas em um âmbito fossem aplicadas no outro. ${ }^{196} \mathrm{O}$ avanço do conhecimento técnico relacionado com a engenharia para a construção de fortificações nos séculos XVI e XVII, por exemplo, influenciou o desenvolvimento da construção de estradas e pontes. E o conhecimento necessário para essas obras, particularmente relacionado com a matemática, muitas vezes estava concentrado nos engenheiros e artilheiros militares (VAN CREVELD, 1991). Posteriormente, o desenvolvimento das ferrovias no âmbito civil, como meio de transporte, teve um impacto significativo na estratégia militar.

A crença de que as instituições militares deveriam evoluir organizacionalmente e tecnologicamente para enfrentar os desafios da guerra moderna contribuiu para que elas desenvolvessem um conhecimento técnico e uma capacidade logística que poderiam ser usados pelo Estado para outras atividades além daquelas relacionadas com o combate, por exemplo, no apoio ao desenvolvimento econômico e social. ${ }^{197}$ Esses fenômenos foram influenciados, também, pelo crescimento da atuação do Estado em diversas áreas, tornando-o multifuncional (HOLSTI, 2004), fazendo com que as Forças Armadas passassem a ser requisitadas para ajudá-lo na multiplicidade das suas tarefas no âmbito

\footnotetext{
${ }^{196}$ A tecnologia e o conflito armado guardam uma estreita relação desde os períodos mais remotos, e a proliferação de estabelecimentos militares das principais nações desenvolvidas está relacionada com o desenvolvimento tecnológico de aplicação militar (JANOWITZ, 1988).

${ }^{197}$ A logística é considerada neste texto como a "provisão, a movimentação e a manutenção de todos os serviços e recursos necessários para sustentar as Forças Armadas " (Griess, Thomas E. (Ed.) Definitions and Doctrine of The Military Art. Wayne, New Jersey: Avery Publishing Group Inc. 1985).
} 
interno. ${ }^{198}$ Embora muitas tarefas dessas Forças estivessem diretamente ligadas à sua missão fundacional, qual seja a defesa contra ameaças externas, outras, de cunho social, desenvolvimentista ou de segurança publica, foram sendo incorporadas. 199

Essa capacidade adicional das Forças Armadas vai ter um papel relevante na ampliação das práticas associadas à diplomacia de defesa. A derrota dos EUA no Vietnã contribuiu para incrementar a crença na forte relação entre os fatores políticos, econômicos, sociais, ambientais e militares, até mesmo no âmbito operacional. Assim, a consciência na importância das operações de estabilização, consideradas como aquelas que englobam atividades militares e civis necessárias para manter a ordem, prover serviços públicos, reparos essenciais e ajuda humanitária, foi ganhando corpo no meio militar, principalmente nos EUA (JANOWITZ, 1971), ${ }^{200}$ como será analisado mais detalhadamente no Capítulo 6.

A partir do fim da Guerra Fria, a ampliação do conceito de segurança e a crença na relação entre segurança e desenvolvimento foram outros fatores que contribuíram para legitimar a ampliação do âmbito da diplomacia de defesa para ações de construção e reconstrução de Estados e suas instituições, e ajuda humanitária e ao desenvolvimento. ${ }^{201}$ Nesse contexto, houve um incremento de operações de paz no período de 1989 a 1994, quando o Conselho de Segurança da ONU autorizou 20 novas operações ${ }^{202}$ destinadas a implementar acordos de paz, estabilizar a situação de segurança, reorganizar os setores militares e a polícia, e

\footnotetext{
${ }^{198}$ Holsti $(2004$, p.29) considera que uma das qualidades essenciais da condição para ser um Estado com legitimidade e longevidade é a sua capacidade multifuncional (a capacidade de realizar eficientemente uma multiplicidade de tarefas e funções) fundamentada em estruturas legítimas de autoridade .

${ }^{199}$ Várias dessas atividades, consideradas em alguns países como "subsidiárias", passaram a estar presentes nas atribuições legais das instituições militares. No Brasil, por exemplo, a Lei Complementar $\mathrm{n}^{\circ} 97$ - de 9 de junho de 1999, que "Dispõe sobre as normas gerais para a organização, o preparo e o emprego das Forças Armadas," estabelece uma série de tarefas subsidiárias relacionadas com o desenvolvimento e a segurança pública.

${ }^{200}$ No contexto da Guerra Fria, os EUA desenvolveram vários programas de treinamento e ajuda, que visavam preparar os militares para enfrentarem os movimentos internos que contestavam os governos.

${ }^{201}$ Para uma análise comparativa da visão tradicional de segurança e das visões que ampliam esse conceito, ver Buzan, Barry; Waever, Ole e Wilde, Jaap. Security. A New Framework for Analysis. Boulder, USA: Lynne Rienner Publishers, 1998.

${ }^{202}$ Uma descrição das operações e das etapas de desenvolvimento das operações de paz da ONU após a Guerra Fria está disponível em: http://www.un.org/en/peacekeeping/operations/surge.shtml. Acesso em: 31jan.2014.
} 
contribuir na realização de eleições nos países atendidos. ${ }^{203}$ A criação do Departamento de Operações de Paz, em 1992, pode ser considerada um marco no processo de incorporação pela ONU da crença de que os militares estão aptos a exercerem um papel muito mais amplo que a mera coerção na segurança internacional. A prática social relacionada com as operações de paz, como visto no capítulo anterior, foi sendo institucionalizada como tarefa nas Forças Armadas de um grande número de países e normatizada, inclusive, em diversos mecanismos bilaterais e multilaterais.

A crença na relação entre segurança e desenvolvimento vai ganhar um impulso, embora com outros contornos, com a ideia de segurança humana proposta na ONU, que clamava por desenvolvimento, ao invés de armas:

\footnotetext{
"O mundo não pode, jamais, estar em paz, a menos que as pessoas tenham segurança no dia-a-dia das suas vidas. Os futuros conflitos serão, normalmente, mais intra-nacionais que entre nações, e suas origens poderão ser encontradas nas desigualdades econômicas e sociais" (ONU, 1994, P.1).
}

Os problemas de direitos humanos no cenário internacional e as dificuldades e os custos relacionados com as operações de paz contribuíram para fortalecer a ideia da prevenção de conflitos, cuja importância já havia sido enfatizada pelo Secretário-Geral da ONU, Boutros Ghali, em 1992, no documento intitulado "Uma Agenda para a Paz" (UN, 1992). No final de 2001, a prevenção também havia sido considerada o mais importante pilar no relatório denominado "A Responsabilidade de Proteger", produzido pela comissão internacional implementada pelo governo do Canadá e outras organizações para estudar a questão da intervenção, em caso de abusos aos direitos humanos, face ao princípio da soberania (ICISS, 2001)..$^{204}$

Após os atentados terroristas de 11 de setembro e, posteriormente, com as dificuldades encontradas no Iraque e no Afeganistão, as potências ocidentais lideradas pelos EUA passaram a defender a ideia de usar os militares para outras tarefas, normalmente associadas ao âmbito civil, fundamentadas na crença de que

\footnotetext{
${ }^{203}$ Para uma análise das operações de "construção de Estados", ver: Paris, Roland e Sisk, Timothy D. (Eds.). The Dilemmas of Statebuilding. Confronting The Contradictions of Postwar Peace Operations. London: Routledge, 2008.

${ }^{204}$ Para uma visão da evolução do conceito de "responsabilidade de proteger", ver Kenkel, Kai M. Global Player ou Espectador nas Margens: A "Responsabilidade de Proteger". Definição e Implicação para o Brasil. Revista da Escola de Guerra Naval n.12 (dez 2008). pp. 6-57.
} 
o fortalecimento do Estado proporcionaria as condições para a "prevenção de conflitos, controle territorial e estabilidade regional" (REVERON, 2010). Assim, a crença na prevenção ganhou maior destaque e institucionalização, especialmente, entre as potências ocidentais, com repercussões nas suas Forças Armadas, com o propósito de evitar a instabilidade e conflito armado (UK, 2011).

Em síntese, da mesma forma que a diplomacia, a diplomacia de defesa se constitui como uma atividade contínua, fundamentada no princípio da soberania estatal, que se institucionaliza por um conjunto de práticas sociais não coercitivas no âmbito da Defesa, sustentadas por crenças e normas que vão se construindo e reproduzindo no tempo e no espaço, e por um processo de burocratização, simbolizado, principalmente, pelas organizações e recursos humanos e financeiros, que a sustentam. ${ }^{205}$ Nesse contexto, ela pode ser definida como uma instituição da sociedade internacional que se constitui pela reprodução, no tempo e no espaço, de práticas sociais específicas de agentes oficiais, para construir e reproduzir as relações não coercitivas no âmbito da Defesa entre os Estados e outras entidades que atuam na política internacional.

\section{5}

\section{Conclusão}

O conjunto de práticas sociais entre os Estados e outras entidades que atuam na política internacional é muito mais do que cooperação, exportação de segurança ou treinamento de militares para atender aos objetivos das grandes potências, como defendido por alguns autores. As práticas, ideias e crenças, e normas relacionadas com o aspecto não coercitivo no âmbito da Defesa constituem uma diplomacia com características e identidade específicas que, conforme a abordagem da Escola Inglesa adotada nesta tese, pode ser considerada uma instituição da sociedade internacional, sub-instituição da diplomacia.

A diplomacia de defesa tem tendido à expansão e ao aprofundamento, na medida em que a institucionalização e a internacionalização no âmbito da Defesa

\footnotetext{
${ }^{205}$ Burocracia é utilizada neste texto para significar "organizações complexas que desempenham tarefas específicas". As ações das burocracias públicas, como as realizadas pelos ministérios da Defesa e as Forças Armadas, são "locus do poder governamental" (KETTL, P. 366-367).
} 
vai se desenvolvendo. O incremento da interdependência e da relação entre a segurança e o desenvolvimento, o alargamento do conceito de segurança, a diminuição conjuntural da probabilidade do conflito interestatal e a natureza ambígua dos recursos militares, foram alguns dos fatores que contribuíram para a ideia da expansão das práticas sociais relacionadas com a diplomacia de defesa.

Tal fenômeno tem sido defendido, seja por propósitos humanitários, ou com o intuito de fortalecer a segurança estatal contra ameaças à sua estabilidade interna, como forma de possibilitar as condições para o desenvolvimento econômico e social, principalmente, de Estados frágeis (SPEAR e WILLIAMS, 2012), ${ }^{206}$ que, embora considerados Estados, não possuem alguns requisitos necessários para a condição estatal, primordialmente, uma efetiva capacidade multifuncional (HOLSTI, 2004). Dessa forma, a diplomacia de defesa vai se constituindo nas relações internacionais, não só em relação aos temas políticoestratégicos e militares, mas, também, em relação à segurança e ao desenvolvimento, participando na prevenção ou no fortalecimento pós-conflito dos Estados e das suas instituições, e, dessa maneira, contribuindo para a manutenção da sociedade internacional.

Diplomatas e militares, como agentes oficiais do Estado, possuem um papel importante na diplomacia como instituição dessa sociedade. Assim, o próximo capítulo busca entender, sucintamente, a relação entre as culturas militar e diplomática e as possíveis influências da expansão e do aprofundamento da diplomacia de defesa na cultura dos militares.

\footnotetext{
${ }^{206}$ Para uma visão dessa relação, ver Joanna Spear e Paul Williams (Eds.): Security and Development in Global Politics - A Critical Comparison. Georgetown University Press, Washington, DC, 2012.
} 


\section{Militares e diplomatas: a questão cultural}

\section{1}

\section{Introdução}

Como visto no capítulo 2, a institucionalização da diplomacia contribuiu para a constituição de uma comunidade diplomática internacional com uma cultura comum. No caso da diplomacia de defesa, a semelhança organizacional no âmbito da Defesa, a difusão das crenças e da doutrina, principalmente, por meio dos estabelecimentos de ensino, e a amplitude do seu processo de institucionalização e internacionalização apontam para a existência de uma comunidade militar internacional, com uma cultura semelhante. Na primeira parte deste capítulo, a questão cultural será abordada no âmbito militar, inclusive em relação às suas diferenças e similitudes com aquela compartilhada pelos diplomatas. A partir do fim da Guerra Fria, a alteração ocorrida no cenário internacional e as mudanças sociais ocorridas, particularmente, nas sociedades democráticas liberais acarretaram alguns desdobramentos no campo da Defesa, com repercussões na cultura militar. Este aspecto será analisado na segunda parte deste Capítulo.

\section{2}

\section{A cultura militar e sua relação com a cultura dos diplomatas}

A relação dos diplomatas com os militares tem uma longa história. Ela está intimamente ligada aos primórdios da diplomacia, que podem ser traçados bem antes da história da diplomacia moderna. Diplomacia e possibilidade do uso da força sempre estiveram unidas, implícita ou explicitamente (SIMPSON, 1980; WATSON, 2004) e os soldados e os diplomatas sempre andaram juntos, embora, muitas vezes, com visões distintas em relação à diplomacia e às relações exteriores (VAGTS, 1956). Inicialmente, como visto no capítulo anterior, a administração das relações de separação entre os Estados também implicava o 
conhecimento pelos diplomatas da capacidade militar de aliados e de possíveis adversários. Entretanto, quando essa função passou a exigir conhecimentos específicos, militares foram designados como embaixadores ${ }^{207}$ ou estes passaram a contar com assessores militares que, no século XIX, ganharam a denominação de adidos militares e um lugar nas representações diplomáticas (SIMPSON, 1980, P.41).

No passado, alguns exemplos mostram que, normalmente, a superespecialização contribuía para uma cultura dos adidos mais belicosa que a dos diplomatas ou associada às questões domésticas dos países que representavam. Alguns deles tinham a tendência de associar suas conclusões referentes ao poderio militar de outros Estados à possibilidade de ataque ao seu país. Outras vezes, eles as associavam às necessidades de recursos para a Forças Armadas à qual pertenciam ou à vontade de não contrariar o pensamento político oficial ou ideias, muitas vezes preconcebidas, já consolidadas no seu país ou na sua Força (VAGTS, 1967).

A presença dos militares agindo diplomaticamente de forma institucionalizada nas embaixadas enfatizou, também, dois outros problemas: a questão da subordinação e o envolvimento dos adidos no âmbito político (VAGTS, 1967, P.4). Se os diplomatas profissionais são estranhos que vivem em outra sociedade da qual não fazem parte (SHARP, 2009), os adidos são duplamente estranhos: da mesma forma que aqueles, em relação ao país onde estão vivendo, e estranhos em relação aos demais diplomatas, pela sua condição de militares fazendo, temporariamente, parte do corpo diplomático (VAGTS, 1967, P.128).

$\mathrm{Na}$ maioria das vezes, essa condição tem gerado, na prática, problemas quanto à dupla subordinação dos adidos militares. Embora a subordinação ao embaixador tenha ganhado respaldo formal com o correr dos anos, os adidos, normalmente, continuam ligados às respectivas Forças Armadas ou ao ministério da Defesa aos quais representam e para os quais enviam relatórios periódicos sobre o país onde desempenham suas funções. Um exemplo dessa múltipla subordinação pode ser visto nas atribuições do Adido de Defesa norte-americano

207 Watson (1982) afirma que Callières, no seu livro sobre a maneira de negociar com um soberano, estabelece algumas qualidades que um negociador deve possuir e, já apontando para a emergência de uma nova profissão, considera que os eclesiásticos, advogados e militares não deveriam ser indicados para as funções diplomáticas, como acontecia à época. 
na Alemanha, que estabelece que além de principal assessor militar do embaixador naquele país, ele ainda representa "o Secretário de Defesa e o Chefe da Junta de Chefes de Estado-Maior...”. ${ }^{208}$ Desta forma, a lealdade à sua instituição e a certeza de que à ela devem retornar após seu período no corpo diplomático são fatores que contribuem para a forte ligação com a sua organização de origem.

Por outro lado, apesar da função do adido poder ser considerada como técnica, a íntima relação entre política e estratégia ou o interesse próprio dos adidos em relação aos temas políticos, algumas vezes, os leva a se envolverem politicamente, inclusive em críticas à condução da diplomacia, gerando, eventualmente, dificuldades para a unidade de ação do corpo diplomático. ${ }^{209}$ Assim, muitas vezes, os relatórios enviados para as Forças Armadas ou para os ministérios da Defesa contêm, também, informações e avaliações de caráter político, o que, embora para alguns possa ser considerado problemático, para outros pode ser muito útil, já que é difícil estabelecer fronteiras rígidas entre temas políticos e estratégicos (VAGTS, 1967).

Apesar dos problemas, a função dos adidos, como os principais assessores militares do embaixador, se propagou na instituição diplomática, e atualmente, eles constituem uma comunidade fardada nos países onde estão representados, que possui normas, regras e práticas institucionalizadas para administrar essa faceta das relações de separação na dimensão militar. Entretanto, ainda que desempenhem uma função diplomática, eles são, primordialmente, militares, que possuem uma cultura própria e é a partir desta constatação que será analisada, sucintamente, a relação entre os militares em geral e os diplomatas. ${ }^{210}$

Diferentes grupos profissionais têm, normalmente, distintas visões das coisas (BRODIE, 1973, P.479). Assim sendo, a administração das relações entre

\footnotetext{
${ }^{208}$ Um exemplo da amplitude das funções de um adido de defesa pode ser visto na página da Embaixada dos EUA na Alemanha na Internet ( United States Diplomatic Mission to Germany. The Defense Attaché's Office-DAO). Disponível em: http://germany.usembassy.gov/about/sections/dao/) Acesso em: 17 abr.2012.

${ }^{209}$ Para uma análise do papel dos adidos no período entre guerras, ver Central Intelligence Agency. The Role of US Army Military Attachés Between the World Wars. Disponível em: https://www.cia.gov/library/center-for-the-study-of-intelligence/csi-publications/csistudies/studies/95unclass/Koch.html: e Vagts, Alfred. op.cit., Capítulo 4.

${ }^{210}$ Nesta tese, a cultura é entendida como um conjunto comum de valores, crenças e ideias que dão significado às práticas, normas e regras de uma instituição. No âmbito militar existem, no entanto, as sub-culturas das Forças e, dentro delas, sub-culturas relacionadas com os diversos corpos e quadros, que só serão mencionadas quando necessário para um melhor entendimento do texto.
} 
os militares e os diplomatas nem sempre tem sido pacífica. Além dos problemas apontados pela dupla subordinação e pelo envolvimento político dos adidos, existem algumas diferenças culturais entre eles. Os primeiros se orgulham de sua integridade profissional, sua disciplina e seu compromisso com a verdade e, eventualmente, consideram que aos diplomatas lhes faltam esses atributos. Por outro lado, para estes últimos, na esfera política, os militares dissimulam tanto quanto eles, principalmente, quando é do interesse das instituições às quais eles representam (VAGTS, 1956, P.1).

A cultura militar implica ideias de honra, que são usadas, em diversas ocasiões, como um conceito superior mais importante que o interesse nacional, mas que poderiam estar escondendo uma resistência às mudanças, em face do conservadorismo que caracteriza as instituições militares. Essa concepção de honra nacional pode se constituir em uma dificuldade para a diplomacia, e é uma diferença cultural em relação à cultura diplomática, onde há uma relutância em considerar honra como um conceito fundamental nas negociações (VAGTS, 1956 ) .

Os militares se distinguem pelo uniforme, pela disciplina, pela lealdade e pelos códigos de conduta e de cortesia, e se definem como homens de ação, cujo sucesso depende do cumprimento das missões que lhes foram atribuídas e, conforme o caso, para alguns deles, "a força pode ser eficaz para lidar com regimes e povos recalcitrantes" (BRODIE, 1973, P.436-486). Outros, no entanto, possuem uma posição mais comedida em relação ao emprego da força nas relações internacionais. No caso do Vietnã, por exemplo, muitos militares, fundamentados na experiência da Coréia, foram contrários ao envolvimento no terreno naquele país asiático e, na sua concepção, o presidente e os lideres no Congresso norte-americano foram os responsáveis pela decisão de intervir (JANOWITZ, 1971). Os diplomatas, por sua vez, também possuem seus próprios códigos de conduta, mas, diferente dos militares, são, essencialmente, homens do entendimento, da negociação e da acomodação. Na tradição diplomática, manter as relações pacíficas em andamento é o principal objetivo da diplomacia (SHARP, 2008) e a visão estritamente militar pode, algumas vezes, complicar o esforço diplomático. ${ }^{211}$

\footnotetext{
${ }^{211}$ Como foi o caso, por exemplo, do projeto Camelot, patrocinado pelo Exército dos EUA que, nos anos 60, usou uma universidade americana para desenvolver estudos em países latino
} 
Os militares normalmente são tidos como conservadores, no sentido em que para eles, por exemplo, o respeito à propriedade privada é a base para a manutenção de uma ordem política estável. Eles desaprovam o desrespeito à autoridade e a desordem, que acreditam caracterizar, algumas vezes, a sociedade civil, em cujas escolas não se difundiriam adequadamente os valores do patriotismo e do respeito às autoridades. No âmbito político, são críticos em relação ao processo político, ao desconhecimento da classe política em relação aos temas de Defesa Nacional, aos recursos financeiros destinados à mesma e às tentativas de intervenção civil na administração militar. Em suma, "o conservadorismo militar revela uma atitude crítica das instituições contemporâneas semelhante às que são esperadas de outros grupos efetivamente profissionais" (JANOWITZ, 1971, P.248-255).

A partir da Segunda Guerra Mundial, os valores dos militares, especialmente, os norte-americanos, se aproximaram dos da sociedade em geral, sendo que, em muitos temas, liderando as mudanças sociais em relação às minorias. Nos anos 1960, duas teorias sobre como os recursos de defesa deveriam ser usados para atingir objetivos políticos competiam entre os militares norteamericanos. Embora fossem apresentadas como distintas em vários aspectos, no fundo, ambas davam voz aos valores sociais e políticos da sociedade. A primeira, denominada absolutista, fundamentava-se na ideia da fronteira e na tradição punitiva, e preconizava o uso máximo da força para atingir os objetivos. Considerava que quanto maior a vitória, mais os objetivos políticos da guerra seriam atingidos. A concepção das relações internacionais desse grupo baseavam suas teorias da segurança nacional nas raízes políticas da tradição da "América como fortaleza". Já a outra escola de pensamento, denominada pragmática, considerava que o "fazer a guerra" era apenas mais um dos instrumentos das relações internacionais que, junto ao econômico e ao ideológico, deveria ser dosado para atingir os objetivos políticos, e defendia o compromisso com um sistema de aliança internacional (JANOWITZ, 1971, P.247-264).

Principalmente nas últimas décadas, a formação profissional dos oficiais das Forças Armadas tem evoluído para uma maior aproximação da formação civil

americanos sobre as causas das insurgências em países em desenvolvimento. Quando a existência do projeto se tornou pública, Brasil e Chile protestaram diplomaticamente, causando o cancelamento do mesmo (SIMPSON, 1980, P.43). 
da sociedade. Como visto no item sobre a diplomacia de defesa como instituição, a tendência tem sido a ampliação nos currículos militares de disciplinas genéricas, algumas das quais relacionadas com a filosofia, a ciência política, as relações internacionais, a administração e a negociação, etc., que reduzem as diferenças entre a formação do diplomata e a do militar. Da mesma forma, especialmente nos EUA, e em menor intensidade em outros países, existe um incremento no número de oficiais que buscam um mestrado ou doutorado voltado, inclusive, para as ciências sociais (VAN CREVELD, 1990, P.102).

Apesar das diferenças apontadas, os diplomatas e os militares possuem muito em comum. Compartilham uma acentuada preocupação com o cerimonial, a cortesia, a etiqueta e o protocolo, embora haja diferenças de grau nesses temas entre as Forças Armadas. Além do mais, suas culturas privilegiam a prática e parecem ter algum preconceito com a teoria e os intelectuais. ${ }^{212}$ Como visto no Capítulo 2, a tradição diplomática do pensamento internacional se fundamenta na experiência prática dos diplomatas e não se prende à determinada teoria para administrar as relações de separação. Manter essas relações da melhor maneira possível é o que importa, e as imagens que associam a prática diplomática com conceitos genéricos nem sempre podem ser consideradas completas, pois "todos os problemas de caráter geral têm, também, um caráter específico e necessitam, usualmente, ser enfrentados da posição específica ocupada pelo diplomata" (SHARP, 2009, P.181).

De forma semelhante, embora defendam a necessidade de uma boa formação educacional, os militares possuem uma posição ambígua em relação ao esforço intelectual, por considerarem que "o intelectualismo sem orientação produz irresponsabilidade" (JANOWITZ, 1971, P.197-199;431). Normalmente, eles dão prioridade à pesquisa intelectual naquilo que se refere à resolução de problemas do campo militar e nem sempre um oficial tido com talento "intelectual" é bem visto na instituição, que, naturalmente, privilegia os "homens de ação", que lutam e vencem batalhas. Isso não significa, porém, que não existiram militares intelectuais que desempenharam um papel importante ao longo da História. Eles eram, entretanto, uma minoria, onde se ressaltam nomes como

\footnotetext{
${ }^{212}$ A atividade militar sempre esteve associada à prática e só a partir do final do século XV se começa a considerar a necessidade do militar atender às escolas e ter um embasamento teórico, fruto, principalmente do avanço tecnológico (VAN CREVELD, 1990, P.12-14).
} 
Clausewitz, na Prússia, de Gaulle e Beaufre, na França (BOENE e MARTIN, 2000, P. 60), Mahan, nos EUA, e Liddell Hart, na Inglaterra. A maior parte dos livros sobre a história militar foi escrita por civis, mas os textos que deram uma maior contribuição sobre os temas abordados foram bem recebidos no meio militar (BRODIE, 1973, P. 436).

Assim, diplomatas e militares têm mantido uma relação ambígua, algumas vezes conflitante, no que se refere ao encaminhamento da diplomacia, já que, em alguns casos, os primeiros acusam os segundos de prejudicarem os avanços diplomáticos quanto à paz, enquanto estes os acusam de buscarem-na a qualquer preço (VAGTS,1956, P.3). No entanto, essa relação mostra, também, outras afinidades, além das já mencionadas.

No âmbito da formulação e condução das políticas externa e de defesa, os diplomatas e os militares preferem ter o predomínio nos seus respectivos campos, e não apreciam a interferência de outros atores nos temas que consideram da sua alçada. Ambos dependem, nos seus planejamentos, da capacidade de predizer eventos e das informações necessárias que permitam conhecer o Outro. Uma eficaz diplomacia necessita desenvolver a capacidade de vislumbrar futuras mudanças na cena internacional e de pensar políticas alternativas para os possíveis cenários. Os militares também dependem de uma boa análise do cenário futuro no âmbito nacional e, principalmente, internacional, para poderem preparar seus planejamentos. Essa capacidade preditiva é extremamente difícil de se alcançar, pois a interação estratégica e a complexidade da vida social complicam esse exercício, que permitiria planejamentos de mais longo prazo (HILSMAN, 1976). Um bom exemplo que demonstra a dificuldade para atingi-la pode ser evidenciado pela incapacidade em se prever o fim da Guerra Fria, que afetou as análises diplomáticas e os planejamentos militares.

Embora os planejamentos militares e as necessidades diplomáticas de longo prazo se assemelhem, existem diferenças culturais quanto à forma como são encarados. A cultura militar busca antecipar os cenários de possíveis conflitos e reduzir as surpresas, incertezas e ambiguidades através do planejamento, e espera dos políticos, diplomatas e outros órgãos do governo uma atitude semelhante. ${ }^{213}$

\footnotetext{
${ }^{213}$ Os planejamentos das forças, normalmente, dependem da confecção dos possíveis cenários para o estabelecimento dos meios a serem incorporados, que muitas vezes necessitam de vários anos para serem desenvolvidos e se tornarem operacionais.
} 
Normalmente, no entanto, isto não acontece. Para os diplomatas, a política e a diplomacia implicam enxergar a ambiguidade e a incerteza como fatores que devem ser considerados e administrados no processo da negociação que leve ao entendimento e ao compromisso (JANOWITZ, 1971).

No âmbito da política externa, como visto anteriormente, os ministérios das Relações Exteriores têm nos ministérios da Defesa um dos seus maiores competidores (HILL, 2003). O processo político de elaboração e implementação da política externa é complexo e pode adquirir diversas formas, dependendo do tema. O debate sobre a política pode ser simplificado e a divisão do trabalho e a especialização das funções dificultam a administração e a coordenação. A dinâmica é de conflito e tentativa de consenso, havendo uma tendência a um processo incremental pela dificuldade de atingir o consenso ou achar alternativas para problemas complexos (HILSMAN, 1971). Os ministérios das Relações Exteriores tentam administrar a condução dessas políticas através de mecanismos de coordenação, que são necessários, conforme apontado anteriormente, principalmente, em relação aos temas político-estratégicos pelos quais os militares normalmente se interessam.

Muitas vezes, no entanto, estes ministérios são criticados por não consubstanciarem uma política externa "eficiente" ou por não terem um planejamento estratégico nos moldes dos utilizados pelos militares, que facilitasse a coordenação dos planos e das ações com o setor da defesa, "nos níveis estratégico, operacional e tático" (ZINNI, 2006). Nos EUA, a reforma do Departamento de Estado já foi preconizada tendo como referência o estabelecimento militar naquilo que corresponde ao uso de ferramentas de planejamento e à estrutura de ensino, particularmente no que concerne aos estudos relacionados com os temas político-estratégicos da política mundial (SIMPSON, 1980). A cultura militar, que privilegia o planejamento e a institucionalização, algumas vezes pode influenciar a cultura diplomática. Em 2010, por exemplo, Hillary Clinton, então Secretária de Estado dos EUA, declarou publicamente terse baseado na publicação Relatório Quadrienal da Defesa, para determinar a 
confecção e aprovar a publicação "Liderando Através do Poder Civil - O Primeiro Relatório Quadrienal da Diplomacia e do Desenvolvimento". ${ }^{214}$

O reconhecimento no âmbito militar do uso de ferramentas de planejamento estratégico associado a um sistema de ensino estruturado, inclusive com cursos nos quais as ciências sociais e, especialmente, os temas políticoestratégicos e as relações internacionais têm tido um maior destaque, contribui, muitas vezes, para uma melhor preparação dos militares para atividades relacionadas com a diplomacia. Nos EUA, desde os anos 30, os militares têm incrementado sua influência nos problemas político- militares da política mundial, e sua preparação diferenciada vem permitindo um papel cada vez mais importante na área da política externa e da diplomacia (SIMPSON, 1980, P. 166).

Historicamente, essa relação entre diplomatas e militares se estende para a ocupação de postos diplomáticos. Alguns militares norte-americanos, por exemplo, criticam o sistema de nomeação de embaixadores não profissionais que, muitas vezes, não possuem o conhecimento e a experiência para lidar com os problemas político-diplomáticos em outros países (ZINNI, 2006). No entanto, houve ocasiões em que muitos soldados foram designados embaixadores (VAGTS, 1956) ou assumiram postos importantes nos ministérios das Relações Exteriores, inclusive, em democracias consolidadas. Nos EUA, “a experiência e a amplitude da função social desenvolvida pela instituição militar" têm contribuído para que militares sejam designados para postos diplomáticos, inclusive como Secretários de Estado, como foi o caso do General George C. Marshall (SIMPSON, 1980, P.44) e, mais recentemente, do General Colin Powell. Por outro lado, o Brasil é um exemplo de país onde nos últimos anos tem ocorrido o inverso, pois, na curta existência do ministério da Defesa, dois diplomatas já ocuparam o principal cargo dessa pasta. ${ }^{215}$

A personalidade dos ministros da Defesa e sua aptidão para os problemas diplomáticos são outros fatores que afetam a cultura organizacional. Eles, normalmente, possuem uma agenda diplomática que extrapola o campo técnico da Defesa e avança para o âmbito político-estratégico com repercussões na política

\footnotetext{
${ }^{214}$ US State Department. "Leading Through Civilian Power- The First Quadrennial Diplomacy and Development Review". Disponível em: http://www.state.gov/documents/organization/153139.pdf. Acesso em: 17 abr.2012.

${ }^{215}$ Os embaixadores José Viegas Filho, durante o primeiro ano, 2003-2004, do governo do presidente Luiz Inácio Lula da Silva; e Celso Amorim, no período de 2011-2014 do governo da presidente Dilma Rousseff.
} 
externa. No caso dos EUA, por exemplo, o papel diplomático do Secretário de Defesa se tornou muito relevante e, algumas vezes, suas visões colidiram com as dos Secretário de Estado, cabendo ao presidente administrar esses conflitos. Muitas vezes, eles se tornaram mensageiros dos presidentes que lhes incumbiam de negociar ou fazer consultas sobre temas sensíveis com autoridades de outros Estados, quando das suas viagens ao exterior.

"O Secretário de Defesa, além de ser um assessor para temas de política externa no Conselho de Segurança Nacional, é um diplomata ativo. Ele se encontra com primeiros-ministros e chefes de Estado, negocia importantes acordos e, de muitas maneiras e em muitos temas, age como um ministro das Relações Exteriores alternativo" (STEVENSON, 2007, P.199-200).

Além dele, no mais alto nível, existem outros importantes atores militares na política externa norte-americana, tais como os comandantes dos seis comandos unificados regionais, que dividem entre eles "áreas de responsabilidade" envolvendo todas as regiões do mundo. A missão, estrutura e capacidade logística dessas organizações contribuem para que seus comandantes sejam um ativo participante na diplomacia regional, exercendo influência nos países onde atuam, disputando, muitas vezes, espaço com os diplomatas (PRIEST, 2004).

Pode-se afirmar, portanto, que da mesma forma que existe uma comunidade diplomática internacional, como visto no Capítulo 2, existe uma comunidade internacional militar com uma cultura e um pensamento que facilitam o diálogo entre militares de diversos países nas relações de separação, de forma semelhante ao que acontece com a cultura e o pensamento da comunidade diplomática. Isso não significa que não existam desconfianças entre os militares de alguns Estados com um histórico de conflito ou uma percepção de antagonismo. No entanto, a diplomacia de defesa é exercida em um ambiente mais propício ao entendimento, na medida em que existe uma cultura comum que facilita o diálogo e "que contribui para criar e manter uma rede global de parceiros no âmbito militar" (REVERON, 2010, P.41). ${ }^{216}$

Além de serem membros de instituições organizadas de forma semelhantes, com valores compartilhados e, normalmente, com doutrinas iguais

\footnotetext{
${ }^{216} \mathrm{O}$ incremento da cooperação militar nesse âmbito entre Alemanha e França após as guerras em que estiveram envolvidas ou, entre Brasil e Argentina, após anos de desconfianças mútuas, é um bom exemplo da capacidade de mudança que a diplomacia é capaz de prover.
} 
ou parecidas, os militares possuem, também, visões e demandas semelhantes, relacionadas com a importância da Defesa Nacional, com o fortalecimento dos meios de Defesa, especialmente das suas próprias Forças, ou com aspectos específicos associados aos orçamentos e salários, apesar dos aspectos culturais específicos de cada serviço e de algumas especialidades dentro deles.

Essa cultura foi sendo expandida com a criação das escolas e centros de adestramento e com as missões militares no exterior, o que propiciou o aumento das interações entre as Forças Armadas e fez com que militares de outros países passassem a ser convidados a cursarem nesses estabelecimentos de ensino, incrementando ainda mais a difusão da cultura militar. Um exemplo de como o pensamento militar é importante nas relações de separação pode ser observado na maneira como a Marinha dos EUA considera o Naval Command College (NCC), curso criado em 1956, no Naval War College, para alunos de outras marinhas:

\begin{abstract}
"De 1956 até a presente data, o NCC graduou 1805 oficiais de 91 nações. Mais de $50 \%$ desses alunos alcançaram o posto de oficiais generais e 209 se tornaram comandantes das suas marinhas. Além disso, dois alunos se tornaram ministros da Defesa, três alcançaram o posto equivalente a Chefe da Junta de Chefes de Estado-Maior, vários ocuparam postos de embaixadores, congressistas e altos postos civis dos governos, sendo que dois se tornaram Chefes de Estado. O resultado é a formação de um ativo grupo de líderes que usam seu entendimento e relações pessoais para construir a confiança que incrementa a cooperação... e influencia positivamente o processo de decisões estratégicas através do mundo." 217
\end{abstract}

A constatação de que os Estados, normalmente, enviam para os cursos e treinamentos oficiais com potencial para alcançarem os mais altos postos, contribui para que essas atividades da diplomacia de defesa sejam consideradas ótimas oportunidades para que as Forças Armadas que as patrocinam influenciarem os militares de outros Estados. Especialmente em relação às democracias ocidentais desenvolvidas, essa tentativa de influência procura ser ampla, não só sobre assuntos diretamente vinculados com a profissão, mas, também, sobre outros temas, tal como o apoio dos militares para fortalecer nos

217 O texto completo da descrição do curso está disponível em: http://www.usnwc.edu/Departments---Colleges/International-Programs/Naval-CommandCollege.aspx. Acesso em 18 abr.2012. 
seus países democracias incipientes ou a implementar a mesma em países com regimes autoritários (BLAIR, 2013). ${ }^{218}$

Em síntese, os diplomatas e militares possuem um papel importante nas relações internacionais como agentes oficiais dos Estados. Esse papel é influenciado pelas respectivas culturas, com suas diferenças e semelhanças e, ainda, pelas mudanças sociais no âmbito doméstico ou internacional. A cultura militar, fundamentada em crenças, normas e regras que são, normalmente, consubstanciadas nas doutrinas, ensinadas nas escolas e praticadas nos exercícios e operações, tende a ser mais disseminada uniformemente entre as FA dos diferentes Estados, facilitando as interações entre os militares e contribuindo para as práticas bilaterais e multilaterais que constituem a diplomacia de defesa.

\section{3}

\section{A cultura militar e o pós Guerra Fria}

No capítulo anterior, foi analisado como, especialmente após o término do conflito ideológico, vários fatores contribuíram para a expansão e o aprofundamento das práticas sociais relacionadas com a diplomacia de defesa. Outros temas e ameaças passaram a ter um maior destaque na agenda de segurança internacional, e algumas missões que, anteriormente, haviam sido relegadas a segundo plano nos planejamentos militares, principalmente pela possibilidade de um conflito entre as grandes potências, ganharam um maior destaque. Além disso, as mudanças sociais, particularmente nas sociedades democráticas liberais, fizeram emergir novas ideias.

Após a Guerra Fria, duas tendências podem ser observadas. A primeira, relacionada com um incremento da participação dos militares em práticas sociais bilaterais e multilaterais relacionadas com a diplomacia de defesa, algumas vezes envolvendo antigos adversários. A segunda, liderada pelas potências ocidentais, especialmente os EUA, relacionada com o reforço da assistência no campo da

\footnotetext{
${ }^{218}$ O almirante norte-americano Dennis Blair (2010) publicou um "handbook", com o propósito de orientar os militares de países democráticos a tentarem influenciar seus companheiros de outros Estados em relação à necessidade da democracia. Nesse livro, ele oferece um roteiro para o desenvolvimento dessa tarefa.
} 
segurança, com o propósito de fortalecer a capacidade dos parceiros em garantí-la no interior dos respectivos Estados e contribuir para a segurança regional e global. Assim, os setores de Defesa tiveram que se adaptar e se reorganizar para cumprir tarefas não relacionadas com o conflito interestatal, fundamentados na crença de que os recursos militares poderiam ser utilizados em outras atividades não coercitivas para ajudar em problemas políticos, econômicos e sociais. Nesse contexto, as potências ocidentais entendiam que se tratava de uma ajuda para "consolidar democracias, liberalizar governos autoritários e evitar a falência de Estados-frágeis" (REVERON, 2010, P.6).

A maior ênfase nessas tarefas fez emergir uma tensão com a cultura militar que, historicamente, privilegia o conflito armado convencional, considerado como a missão principal das Forças Armadas. ${ }^{219}$ Embora as tensões relacionadas com a diplomacia de defesa venham a ser debatidas em maior profundidade no próximo capítulo, algumas considerações são úteis para o entendimento do impacto dessas "novas" tarefas na cultura militar.

Nos EUA, os defensores da concepção absolutista tiveram suas ideias contempladas nos anos 80 pelas Doutrinas Weinberger e Powell, que defendiam o uso dos recursos militares apenas quando houvesse um "interesse nacional" em jogo e o apoio do Congresso e da população, utilizando a força máxima para vencer a guerra. O problema com essa concepção, fundamentada no modelo da Segunda Guerra Mundial, já não correspondia a um ambiente estratégico em mutação, que não era facilmente observado, pois predominava a lógica da Guerra Fria (JORDAN, TAYLOR e MAZARR, 1999). Com o fim do conflito ideológico, ficou evidente que os conflitos estatais estavam em declínio, que a vitória militar não garantia uma paz estável, e que o emprego dos recursos militares se dava de forma limitada em situações onde a violência era apenas um dos componentes, em um mosaico de fatores políticos, econômicos e psicossociais. O novo ambiente estratégico era muito menos rígido e implicava, principalmente, nas questões da ajuda humanitária e ao desenvolvimento, estabilização, construção e reconstrução relacionados com o fortalecimento de Estados frágeis, assim como na assistência de segurança e defesa.

\footnotetext{
${ }^{219}$ Para uma visão norte-americana dessa preferência, ver: Weigley, Russell. The American Way of War: A History of U.S. Military Strategy and Policy (New York, Macmillan, 1973)
} 
Assim, durante o Governo Clinton, o Pentágono viu-se obrigado a se adaptar à ideia de que as Forças Armadas teriam que fazer mais do que se preparar para um conflito interestatal. Os militares, então, receberam do governo e se prepararam para cumprir uma série de tarefas que, normalmente, poderiam ser realizadas por agências civis (PRIEST, 2004, P.45). Apesar das resistências encontradas, a cultura da obediência e do cumprimento das ordens foi um dos fatores que contribuíram para que eles se engajassem nessas novas tarefas que ampliavam o escopo da diplomacia de defesa.

A cultura militar teve que se adaptar para essa nova moldura políticoestratégica, mais próxima da ideia da escola que defendia uma postura mais flexível no pensamento militar. Essa mudança cultural implicava um treinamento e preparação com a exigência de um maior conhecimento sobre os problemas políticos, sociais, econômicos e culturais da área de atuação. Da mesma forma que os diplomatas, os militares tinham que se adaptar às realidades práticas do país onde atuavam, que muitas vezes não condiziam com as ideias e políticas estabelecidas por aqueles que desconheciam a complexidade dos ambientes em que eles estavam operando. Esse conflito se tornava mais complexo, pois, além de terem que lidar com os problemas relacionados com as diferenças culturais do país onde operavam, eles tinham, ainda, que entender e interagir com as diferentes culturas dos agentes estatais civis, intergovernamentais e das organizações nãogovernamentais atuando localmente (ZINNI, 2006). ${ }^{220}$

Segundo Moskos, Williams e Segal (2000), a evolução no panorama políticoestratégico e o processo de globalização tornaram-se tão intensos, que se poderia afirmar que as Forças Armadas das democracias ocidentais desenvolvidas estariam em um processo de mudança de uma forma de organização do tipo moderna para outra, pós-moderna. A primeira, estaria associada ao desenvolvimento do Estado-nação e prevaleceu na sua forma mais recente até o princípio dos anos 90. Caracterizar-se-ia pelo propósito de lutar guerras, utilizando o recrutamento obrigatório dos militares de graduação mais baixa e um corpo de oficiais profissionais, com uma cultura masculinizada e nitidamente

\footnotetext{
${ }^{220}$ Segundo o General Tonni Zinni (2006), lidar com as organizações não-governamentais em operações de caráter humanitário é uma experiência difícil que "requer uma sensibilidade cultural semelhante àquela necessária para lidar com outros povos e culturas". Cada uma tem sua própria cultura, missão e história e atua, normalmente, independentemente das outras, competindo por doações e recursos.
} 
diferente daquela existente na sociedade civil. Essa situação estaria evoluindo ante à redução da possibilidade do conflito interestatal e do fenômeno da globalização para uma forma de organização militar que, embora ainda enfatizasse o patriotismo, estaria mais próxima e permeável aos valores da sociedade, constituída de recursos humanos profissionais admitidos voluntariamente, encarregados de um amplo leque de missões, com a erosão dos valores marciais e com uma cultura caminhando para se tornar mais "andrógina" (MOSKOS, WILLIAMS e SEGAL, 2000, P.1-3). ${ }^{221}$

A organização militar pós-moderna se caracterizaria por algumas grandes mudanças, entre as quais de interesse para esse trabalho seriam:

“...o incremento da inter-relação entre as esferas civis e militares, tanto estruturalmente quanto culturalmente, e a mudança no propósito militar de lutar guerras para missões não relacionadas com o combate ... (MOSKOS,WILLIAMS e SEGAL, 2000, p.2).

Essa visão tem semelhanças com a análise efetuada nos anos 1960 e 1970 por Morris Janowitz $(1971,1977)$ sobre as instituições militares, inclusive aquelas pertencentes aos países em desenvolvimento, que considerava que, devido aos avanços tecnológicos, as características dessas instituições tenderiam a se aproximar daquelas das grandes organizações governamentais ou empresariais. Assim, "as diferenças entre militares e civis tornar-se-iam seriamente enfraquecidas", na medida em que haveria uma democratização no recrutamento dos oficiais, um estilo de liderança menos autoritário e uma redução na diferenciação das habilidades necessárias para o desempenho de funções nas organizações tanto militares quanto civis.

Por outro lado, a ampliação dos conhecimentos transmitidos nas escolas militares, incluindo temas políticos, sociais e econômicos, contribuiria para que os militares incrementassem a sua capacidade crítica em relação a esses temas, gerando a possibilidade de um potencial conflito de ideias com as lideranças civis. No entanto, Janowitz $(1971,1977)$ reconhecia que, embora existissem

\footnotetext{
${ }^{221}$ Embora a instituição militar tenha que se adaptar às mudanças que acontecem na sociedade, e algumas vezes ela possa estar, até, à frente de determinadas mudanças sociais, a cultura militar tem um viés conservador, como visto anteriormente. Nos EUA, por exemplo, "o General Colin Powell ameaçou renunciar ao cargo de Presidente da Junta de Chefes do Estado-Maior se o presidente Clinton cumprisse a sua promessa de campanha de permitir que os homossexuais servissem abertamente nas forças armadas" (PRIEST, 2004, P.44).
} 
semelhanças entre os dois grupos, a função básica dos militares seria lutar em combate, e isso implicaria em uma diferença em relação às funções desempenhadas pelos civis. Uma sociedade democrática, portanto, deveria integrar os militares, baseando-se na diferenciação das suas habilidades e códigos de valores, e, não, tentando igualá-los aos civis. ${ }^{222}$

Embora uma parte da formação profissional dos militares tenha evoluído para uma aproximação da formação civil, existem indícios de que, em relação aos EUA, por exemplo, existiria uma tendência a aumentar o espaço entre as duas culturas. Segundo Ricks (1997), os valores da cultura militar, que tendem a um maior grau de homogeneidade entre os militares, confrontam-se com o individualismo, a indisciplina e a reivindicação de direitos, sem a menção aos deveres que são encontrados em parcelas da sociedade. Existe uma tendência da sociedade norte-americana a se tornar "menos influenciada pelas instituições tradicionais, tais como a família, a escola e a igreja, e se tornar mais individualista e menos disciplinada" (RICKS, 1997).

Esse problema seria agravado pela diversidade cultural da sociedade norteamericana, que contribui para a formação de "tribos", vivendo em enclaves (LEWIS, 2007) e pela falta de experiência ou do conhecimento, no âmbito militar, das elites políticas, não só nos EUA (RICKS, 1997), como em outros países (DANDEKER, 2000). Dessa forma, os militares teriam a percepção de que são culturalmente diferentes em relação à maioria da sociedade. Assim, pesquisa realizada com um grupo de militares norte-americanos, em 2011, mostrou que a maioria é politicamente conservadora e que cerca de $70 \%$ consideraram que "a comunidade militar tem pouco em comum com o resto do país; e que a maioria dos civis não entendem os militares" ${ }^{\text {} 223}$, percentual que subiu para cerca de $76 \%$ na pesquisa de $2012 .^{224}$

Assim, o argumento de uma organização militar "pós-moderna", na qual existiria uma inter-relação, tanto estrutural quanto cultural, com a esfera civil, tem, porém, limite impeditivo para sua igualdade, pois, principalmente por sua

\footnotetext{
${ }^{222}$ Segundo Feaver (2003), Samuel P. Huttington desenvolveu uma abordagem que defende a existência da diferença entre civis e militares. Janowitz, mais tarde, argumentou que os avanços tecnológicos e as guerras limitadas estavam diluindo essa fronteira, sem, no entanto, contestar "uma essencial diferença de papéis entre os dois grupos" (FEAVER, 2003, p. 7-10) .

${ }^{223}$ A pesquisa completa pode ser vista em: http://projects.militarytimes.com/polls/2011/results/politics/. Acesso em: 10 dez.2013. ${ }^{224}$ A pesquisa completa pode ser vista em: http://projects.militarytimes.com/polls/2012/results/politics/ .Acesso em:10 dez. 2013.
} 
responsabilidade de administrar os instrumentos de força para garantir a segurança externa, as Forças Armadas dificilmente serão transformadas em uma organização civil. Além do mais, a cultura militar, como visto anteriormente, tem peculiaridades que, normalmente, a diferenciam da cultura dos outros grupos sociais. Apesar de muitas atividades de apoio no âmbito militar não divergirem muito daquelas do meio civil, as missões dos militares na preparação para o combate, fundamentado em valores, tais como a defesa da Pátria, fazem a diferença. Mesmo hoje, quando se afirma que existem companhias civis de segurança que podem fazer o mesmo trabalho dos militares, os valores incutidos nas Forças Armadas os diferenciam daqueles que são motivados pelo lucro.

Da mesma forma, o argumento da mudança do propósito militar "de lutar guerras para missões não relacionadas com o combate" (REVERON, 2010) deve ser visto com cautela. Embora, como argumentado nesta tese, exista um incremento das tarefas não coercitivas, isso não significa que houve ou esteja havendo uma mudança de propósitos das Forças Armadas. Afinal, a cultura do combate é considerada primordial, pois mantém coerência com a principal missão de garantia da segurança externa, expressa, normalmente, em documentos de alto nível dos Estados, inclusive, em algumas Constituições. ${ }^{225}$ As demais tarefas, tais como as ligadas ao desenvolvimento, catástrofes ou relacionadas com a lei e a ordem em casos específicos estabelecidos no arcabouço legal de cada país (BLAIR, 2013) são, normalmente, consideradas subsidiárias ou secundárias, mesmo quando ganham destaque na agenda militar.

Embora o incremento das tarefas secundárias seja uma tendência crescente no contexto de baixa probabilidade de conflito inter-estatal e os militares estejam se preparando e organizando para cumpri-las, culturalmente, prevalece a prioridade da preparação para o combate em missões contra ameaças externas (BLAIR, 2013, p.18). Esse fenômeno é constatado, por exemplo, em pesquisa

\footnotetext{
${ }^{225}$ Essa tarefa, normalmente, está expressa nas estratégias de segurança ou de defesa dos Estados, como pode ser visto, por exemplo, nos documentos da Rússia, China e EUA (Russia's National Security Strategy to 2020. Disponível em: http://rustrans.wikidot.com/russia-s-national-securitystrategy-to-2020. Acesso em: 12 jan.2012; China's National Defense in 2010. Disponível em : http://news.xinhuanet.com/english2010/china/2011-03/31/c_13806851.htm. Acesso em 23 fev.2012; US National Security Strategy, May, 2010. Disponível em: http://www.whitehouse.gov/sites/default/files/rss_viewer/national_security_strategy.pdf. Acesso em:10 dez.2013). A Constituição brasileira, por exemplo, estabelece no seu Artigo 142 que as FA "destinam-se à defesa da Pátria, à garantia dos poderes constitucionais e, por iniciativa de qualquer destes, da lei e da ordem." Disponível em: http://www.planalto.gov.br/ccivil_03/constituicao/constituicao.htm. Acesso em: 10 fev.2014.
} 
realizada com oficiais norte-americanos no nível médio da carreira. Mesmo havendo um maior apoio nessas tarefas não tradicionais, que ganharam maior destaque na agenda de segurança no pós Guerra Fria, a maioria dos entrevistados consideraram as missões tradicionais mais importantes e merecedoras de maior apoio (AVANT e LEBOVICK, 2002).

Assim, inúmeros países desenvolvidos ou em desenvolvimento se prepararam para atuar em apoio a missões não coercitivas, mantendo, porém, suas capacidades de combate. ${ }^{226}$ Países como a Grã-Bretanha, a França e a Alemanha, por exemplo, após a Guerra Fria, se prepararam para atender externamente as missões de apoio à paz, mantendo, no entanto, a capacidade para atuar em cenários de guerra com diferentes níveis de intensidade (DANDEKER, 2000; BOENE e MARTIN, 2000; FLECKENSTEIN, 2000).

Operações relacionadas com as forças de paz, a ajuda humanitária e ao desenvolvimento, a prevenção de conflitos e a reconstrução de Estados e suas instituições, ao ganharem um maior destaque na agenda internacional, têm contribuído para uma maior atenção das Forças Armadas ao fator cultural. Dispersas por várias regiões do mundo, e com a participação de um maior número de atores, elas obrigam os militares a se envolverem com um amplo leque de culturas, dentre as quais as das regiões, países e localidades onde atuam, das peculiaridades culturais dos demais aliados e componentes militares e civis dessas operações, das organizações civis governamentais e não-governamentais. Essa complexidade afeta as tarefas realizadas. Embora, desde antes da Guerra Fria, o planejamento para operações tivesse como um dos seus itens a análise dos fatores psicossociais, nos últimos anos, o fator cultural se tornou mais complexo. Por isso, a cultura tem ganhado nas organizações militares, principalmente nos EUA, uma maior importância.

Desta forma, o Departamento de Defesa publicou, em 2005, o Roteiro para a Transformação da Linguagem da Defesa. Esse documento se fundamenta no reconhecimento de que o fator cultural não era considerado importante na

\footnotetext{
${ }^{226}$ Em dezembro de 2013, 122 países participavam de operações de paz da ONU. Os países menos desenvolvidos lideram a contribuição de pessoal para essas operações. Disponível em http://www.un.org/en/peacekeeping/contributors/2013/dec13_2.pdf. Acesso em: 10 fev.2014. Por outro lado, cerca de $80 \%$ dos recursos financeiros foram disponibilizados pelos cinco membros permanentes do Conselho de Segurança da ONU, mais Japão, Alemanha, Itália, Canadá e Espanha. Disponível em: http://www.un.org/en/peacekeeping/operations/financing.shtml. Acesso em: 10 fev.2014.
} 
preparação para o combate, e que, principalmente a partir dos atentados terroristas de 11 de setembro, a necessidade de entendimento das diversas culturas se tornou fundamental. Seu principal objetivo é desenvolver entre os civis e militares da ativa e da reserva, do setor de Defesa, uma capacidade que inclua o domínio de vários idiomas e o conhecimento de diversas regiões, com o propósito de melhor entender as culturas de onde operam ou poderão operar, contribuindo, assim, para melhorar seu desempenho nas operações. Desta forma, algumas medidas foram adotadas, tais como a introdução do tema na doutrina, o estudo das diversas regiões do mundo e seus aspectos culturais no sistema de ensino militar, e a introdução do critério de conhecimento de idiomas para a promoção a oficialgeneral (US-DoD, 2005, p.1).

Além da determinação para o desenvolvimento pessoal dessa capacidade de uma forma geral, o Departamento de Defesa aprimorou um programa para dotar os comandos militares combatentes, as agências de defesa e os escritórios dos adidos nas embaixadas com oficiais especialmente preparados para o assessoramento cultural. O entendimento daquele Departamento é que:

“...as capacidades críticas para o combate incluem o conhecimento de idiomas e o estudo das regiões do mundo. Esse conhecimento cultural, além de contribuir para um melhor desempenho nas operações, facilita o desenvolvimento das interações relacionadas com a diplomacia de defesa, não só com os governos estrangeiros, mas, particularmente, com os seus estabelecimentos de Defesa e militares, o que é essencial para desenvolver e manter um relacionamento mutuamente construtivo, tanto bilateral quanto multilateralmente." (US-DoD, 2005, P.2).

As determinações do Roteiro têm gerado um movimento para a incorporação do fator cultural nas FA norte-americanas. A Marinha, fundamentada na sua tradição de operar no exterior, estabeleceu uma estratégia linguística e cultural, com o propósito de se tornar um Força que:

"Aprecia e respeita as diferenças culturais e reconhece os riscos e as consequências de um comportamento culturalmente inapropriado, mesmo que não intencional, nas interações com outros atores" (US-DN, 2008, P.7).

Da mesma forma, a necessidade de operar junto com os civis na abordagem denominada de "whole of government approach" tem levado os 
militares norte-americanos a aprenderem sobre as culturas das agências civis governamentais, a fim de que o entendimento das mesmas possibilite um relacionamento mais harmonioso, eficaz e eficiente durante as operações. Segundo o manual do Estado-Maior Conjunto, na participação dos militares com essas agências, particularmente, em operações de reconstrução e estabilização, é importante entender as diferenças. Assim, o documento preconiza que:

"Devem ser entendidas as diferenças, tanto nos motivos, objetivos, perspectivas culturas entre os diversos atores envolvidos. Esse entendimento contribui para a flexibilidade no pensamento, a adaptabilidade no planejamento e o compromisso no desenvolvimento dos objetivos" (US-JCS, 2010, P. I-5).

O Exército norte-americano, por sua vez, definiu a competência cultural como uma das capacidades que um soldado e um líder militar devem desenvolver para atuar contra ameaças convencionais e não convencionais em qualquer região do planeta, em um ambiente em que exista a possibilidade de interação com diversos atores governamentais e não-governamentais. Desta forma, estabeleceuse um conjunto de conhecimentos de caráter geral e regional que possibilitem ao militar interagir em um ambiente culturalmente complexo para ser capaz, dentre outras tarefas, de:

“...entender os fatores políticos, econômicos, sociais e militares regionais e locais, entender ambientes complexos, entender e comunicar-se com diferentes culturas, estabelecer relacionamentos efetivos, negociar e construir consensos..." (US-DA, 2013, P.2-4).

Manuais militares de outros países, como por exemplo, a Grã-Bretanha e o Brasil, também apontam para a importância dos fatores culturais, ressaltando:

" Cultura e crenças influenciam como as pessoas se comportam, e como esse comportamento é interpretado. Cultura desempenha um papel na maneira como as pessoas engajam nos conflitos, portanto o desenvolvimento e entendimento desses fatores são uma importante capacidade militar" (UK, ARMY 2010, p.5-6)

" Os elementos da Força Terrestre devem adquirir uma acurada compreensão da dimensão humana do Teatro de Operações, ressaltando a cultura local, costumes e leis, da economia, da estrutura social, modo de vida da população local e o sistema de crenças, dentre outros" (BRASIL, EB20-MF-10.103,2014:p.3-18). 


\section{4}

\section{Conclusão}

Os militares formam uma comunidade na sociedade internacional com uma cultura semelhante, que se relaciona de forma ambígua à cultura diplomática: em alguns pontos, elas se aproximam e, em outros, se distanciam. O fim da Guerra Fria, no entanto, tem trazido novos elementos à questão cultural.

O ambiente estratégico durante o conflito ideológico era, de certa forma, mais definido e a questão cultural tinha um papel menos importante para as Forças Armadas. A mudança para um contexto de multipolaridade, de diversificação das ameaças, das regiões de possível atuação das Forças Armadas e de incremento do número e da diversidade de atores torna a interação dos militares mais complexa. Assim, eles são obrigados a entender diversas culturas, não só dos países onde atuam, mas, também, dos aliados e dos diversos atores governamentais e não-governamentais que interagem no âmbito das suas operações.

A percepção dessa necessidade e a implementação das medidas tomadas pelo Departamento de Estado e pelas Forças Armadas norte-americanas para incrementar a cultura como uma capacidade que o militar deve adquirir caracterizam uma inovação ideológica e de valores no seio dessas organizações. Normalmente, em tempos de paz, mudanças desse tipo, para terem maior chance de sucesso, devem ser adotadas por estratégias conduzidas pelos chefes militares que estabelecem a orientação intelectual e as mudanças organizacionais necessárias para sua implementação (ROSEN, 1991). Esse parece ser o caso da questão cultural nas Forças Armadas norte-americanas. Embora seja ainda muito cedo para avaliar os resultados dessa mudança, pode-se afirmar que a cultura tem, hoje, uma maior dimensão no âmbito militar, afetando, portanto, a diplomacia de defesa, já que a comunidade militar internacional possui diversos canais de disseminação de conhecimentos e ideias, o que contribui para um elevado grau de homogeneização doutrinário.

Por outro lado, apesar das alterações ocorridas no pós Guerra Fria, é prematuro afirmar que os militares estão cada vez mais abandonando a cultura do combate para se transformarem em "forças de cooperação". Em síntese, a defesa 
da Pátria contra ameaças externas continua sendo a principal missão das Forças Armadas, e embora outras tarefas sejam realizadas pelas mesmas, "é a vitória na guerra que, em última instância, legitima uma organização militar” (ROSEN, 1991, p.20).

No entanto, essas mesmas alterações têm contribuído para que os militares atuem em um ambiente culturalmente mais complexo, exigindo dos mesmos habilidades que os aproxima daquelas existentes na cultura diplomática. Essa atuação gera tensões que são motivo de debates tanto nas Forças Armadas quanto no governo e na sociedade em geral, como veremos no próximo capítulo. 


\section{Críticas e tensões relacionadas com a diplomacia de defesa}

\section{1}

\section{Introdução}

O processo de expansão e aprofundamento da diplomacia de defesa tem gerado algumas críticas e tensões. Este capítulo analisa, na primeira parte, essas questões, exemplificando-as em relação a alguns países, especialmente os EUA, que têm uma diplomacia de defesa muito mais abrangente no cenário internacional, constituída no contexto de única superpotência militar. Na segunda parte, é analisada a questão da coordenação necessária para se amenizar algumas das tensões e tentar garantir coerência dos diversos atores estatais quanto aos objetivos de política externa.

\section{2}

\section{Desmilitarização da defesa e militarização da diplomacia}

A diplomacia de defesa contribui para a administração pacífica das relações entre os Estados; no entanto, no processo de incremento da sua amplitude e profundidade, críticas e tensões vão se constituindo. Essas reações estão ligadas, normalmente, ao seu avanço para outras áreas, muitas das quais de responsabilidade de agências civis. As críticas, especialmente no que concerne ao seu envolvimento em tarefas voltadas ao desenvolvimento e a ajuda humanitária, partem de vários setores, tais como militares, congressistas, agências do governo, ONGs, acadêmicos e analistas de defesa (REVERON, 2010).

Entre os críticos, principalmente no meio militar, existem aqueles que consideram que essa expansão contribui para a desmilitarização da Defesa. As críticas desse grupo estão associadas às tensões geradas pela utilização dos recursos militares em tarefas não concernentes ao espectro coercitivo do aparato militar do Estado. A principal preocupação estaria relacionada com a 
possibilidade das Forças Armadas perderem a capacidade de cumprir a sua missão fundamental de defesa contra ameaças externas, que exige uma preparação voltada para o combate, por estarem focadas em outras tarefas consideradas "subsidiárias". Como visto anteriormente, essas Forças, normalmente, cumprem outras tarefas em tempos de paz. No entanto, em períodos de baixa probabilidade de conflito armado, existe uma maior pressão para que os seus recursos humanos e materiais sejam usados para apoiar atividades inerentes ao desenvolvimento econômico e social, especialmente nos países em desenvolvimento.

No âmbito da diplomacia de defesa, esse debate também ocorre, e os críticos alegam que existe o perigo da perda da capacidade combativa das Forças Armadas, quando elas se dedicam a determinadas tarefas, tais como aquelas ligadas ao peacebuilding e o peacekeeping (COTTEY e FOSTER, 2004 p.74). Neste contexto, a missão principal dos militares seria "lutar nas guerras" e as atividades associadas à ajuda humanitária, reconstrução de Estados etc. estariam desvirtuando e enfraquecendo as Forças Armadas (BIDEN, 2008), e constituindo uma tensão entre a socialização, entendida como incorporação e internalização das normas, para o combate e para as atividades subsidiárias.

Por outro lado, há os que consideram que essa expansão militariza a ajuda ao desenvolvimento e os empreendimentos humanitários. Para este grupo, normalmente constituído daqueles que pertencem a organizações civis governamentais e não governamentais, esse fenômeno reduz a participação e, até mesmo, coloca em risco o esforço civil desenvolvido nessas atividades.

O incremento do papel da diplomacia de defesa também é visto por outros críticos, dentro e fora dos governos, como constituindo um processo de militarização da mesma, que se daria, basicamente, pela ampliação da atuação dos militares nas questões diplomáticas. A cultura semelhante dos militares, o grau de institucionalização dessa diplomacia e os recursos à disposição das Forças Armadas, são alguns fatores que possibilitam um papel mais relevante e uma maior autonomia aos principais atores dessas práticas diplomáticas. Esse processo gera tensões que emergem da possibilidade de conflito entre a liberdade de ação que ele enseja e a necessidade de subordinação da diplomacia de defesa aos objetivos da política externa, a fim de garantir um grau de coerência nesta política, segundo os pressupostos de subordinação militar ao governo civil. 
Nos EUA, especificamente em relação à militarização da diplomacia e da ajuda internacional, existem críticas de algumas organizações não governamentais à expansão dos militares para áreas relacionadas com o desenvolvimento, que deveriam ser deixadas nas mãos de outras agências civis. ${ }^{227}$ Por outro lado, eles consideram que a atuação dos militares na ajuda internacional em grandes crises humanitárias e desastres naturais pode, eventualmente, ser útil, devido à capacidade logística das Forças Armadas. Além do mais, muitas organizações não governamentais consideram que trabalhar conjuntamente com os militares é problemático, porque pode gerar desconfianças na população que eles buscam auxiliar (US-OIG, 2009, p.14). Outro argumento apresentado é que os atores civis seriam tecnicamente mais aptos para desenvolver projetos de longo prazo e, no caso das ONGs, melhor aceitos pela população local, devido à sua suposta imparcialidade (CHARNY, 2013).

Algumas dessas organizações, além de acentuarem essas vantagens comparativas em relação ao pessoal militar na ajuda humanitária, também defendem maiores recursos para o Departamento de Estado e para os setores civis encarregados da ajuda internacional, e criticam o crescimento do papel e dos recursos que o Departamento de Defesa vem implementando nesse campo. Nessa visão, o incremento da atuação dos comandos combinados regionais norteamericanos, a "militarização" da ajuda para o desenvolvimento e a projeção dos militares nos aspectos diplomáticos estariam "minando a autoridade do Secretário de Estado para estabelecer a agenda de política externa" (RUPP, 2008).

O Congresso norte-americano também tem avaliado o tema do maior envolvimento dos militares na política externa dos EUA, e alguns congressistas reconhecem o aumento dessa participação, principalmente a partir dos atentados terroristas de 11 de setembro de 2001. Desde então, segundo o atual vicepresidente dos EUA, Joe Biden, "tem havido um movimento de transferência de funções e autoridade das agências civis para o Departamento de Defesa", que tem recebido mais recursos e flexibilidade para administrá-las, inclusive, em programas associados a atividades de estabilização, assistência humanitária e

\footnotetext{
${ }^{227}$ Uma crítica à essa expansão do Departamento de Defesa com sugestões ao Congresso e ao Governo dos EUA para alterar essa situação pode ser vista no texto “ The US Military's Expanding Role in Foreign Assistance. Disponível em: http://www.interaction.org/files/FABB\%202013_Sec16_NGOAndMilitaryRelations.pdf. Acesso em: 29 mai.2013.
} 
ajuda internacional. Alguns problemas apontados por essa tendência seriam: a possibilidade da política externa projetar uma imagem distorcida, devido à maior atuação do Departamento de Defesa, desviar os militares das suas missões de combate e de treinamento das Forças Armadas de outros países, e associar a ajuda internacional a objetivos de curto prazo (BIDEN, 2008).

Finalmente, para outros críticos, a preocupação com as inúmeras agências e programas estaria voltada, principalmente, à falta de transparência e, nem tanto, à eficiência estatal ou à militarização da diplomacia ou da ajuda internacional. Os programas conduzidos pelo Departamento de Defesa teriam menos controle do Congresso do que aqueles conduzidos pelo Departamento de Estado, o que poderia possibilitar formas de contornar as proibições de ajuda a países considerados pelos EUA como possuindo problemas quanto aos direitos humanos (ISACSON e OLSON, 1998, P.ix).

As críticas e tensões apontadas, normalmente, são vistas das perspectivas dos diversos grupos que debatem o tema. No entanto, como será discutido a seguir, nesta tese se defende que essas questões estão inter-relacionadas com vários fatores, tais como o papel multifuncional do Estado, a interdependência no âmbito mundial, a crença de que desenvolvimento, segurança e defesa estão interligados, a ampliação do conceito de segurança, e a questão conjuntural da baixa probabilidade do conflito interestatal.

\section{3}

\section{A ampliação do papel do Estado e a interdependência}

Como visto na discussão conceitual, a ampliação do papel do Estado no âmbito doméstico e o avanço da interdependência incrementaram o papel da diplomacia (WATSON,1982, p.176-178). A esse entendimento, acrescento o conceito de Estado multifuncional, defendido por Holsti, para argumentar que, em relação ao âmbito doméstico, as necessidades dos Estados de atuarem em várias áreas contribuem para que os militares sejam demandados pelos governos para que participem desse esforço estatal, atuando em setores além daqueles estritamente militares. Isso tem gerado o fenômeno denominado, neste trabalho, Forças Armadas multifuncionais que, em muitos países, além da garantia da 
segurança interna e externa, possuem outras tarefas, inclusive, relacionadas com o desenvolvimento econômico e social.

As capacidades organizacionais e logísticas dessas Forças, desenvolvidas e mantidas com recursos muitas vezes substanciais do orçamento estatal, são um insumo importante com que o Estado conta para auxiliá-lo no desempenho de algumas das suas múltiplas atribuições, especialmente em períodos de baixa probabilidade do conflito interestatal e em um contexto no qual outros órgãos do governo, que seriam os responsáveis primeiros pelo seu planejamento e execução, sejam fracos ou insuficientes. Isso é facilitado pela natureza dual de várias tecnologias empregadas no âmbito da Defesa, que podem contribuir para o desenvolvimento econômico e social, assim como pela natureza ambígua dos recursos militares, que possibilita a sua atuação em atividades relacionadas com desastres naturais, programas sociais na saúde, educação, construção civil, etc.

Até mesmo em temas globais como o meio-ambiente, por muitos defendido como um exemplo das limitações do papel do Estado, as capacidades das Forças Armadas e a natureza ambígua dos recursos de defesa são reconhecidas, inclusive, pela $\mathrm{ONU}$, como uma importante fonte para a sua proteção. Um relatório do estudo sobre os usos potenciais dos recursos militares, conduzido sob patrocínio dessa instituição, cita os EUA, Brasil, Alemanha, Suécia e China como exemplos de países nos quais esses recursos possuem um papel relacionado ao meio-ambiente. $\mathrm{O}$ documento afirma:

\begin{abstract}
"De certa forma, os estabelecimentos militares estão numa posição única para fortalecer as capacidades civis internacionais para a implementação de estratégias ambientais. Os militares estão bem equipados para lidar com situações catastróficas, o que poderia ser útil na resposta a desastres ambientais e de manuseio e descarte de substâncias tóxicas. A comunidade de defesa tem à sua disposição uma grande quantidade de informações coletadas que podem ajudar a acompanhar as mudanças na atmosfera, nos oceanos e na superfície da Terra... Como esses recursos são inerentemente nacionais e o desafio do meio-ambiente é global... seu possível emprego, no âmbito multilateral, para lidar com os problemas ambientais, só pode ser realizado em conformidade com os princípios estabelecidos do direito internacional e do respeito pela soberania nacional. Algumas lições aprendidas a partir da experiência das Nações Unidas na promoção da cooperação internacional técnica podem ajudar nesse sentido" (ONU,1993, p.16-34).
\end{abstract}

A capacidade multifuncional das Forças Armadas, por um lado, se constitui como uma demanda do Estado nas suas necessidades de alcançar um 
bom desempenho na multiplicidade das suas tarefas, mas, por outro, pode se constituir, também, uma necessidade das próprias Forças, por três razões principais. Primeiro, porque os militares entendem que, normalmente, desenvolvimento e defesa estão associados. A existência de Forças Armadas aptas a cumprirem suas missões, no tempo e no espaço, depende da capacidade de desenvolvimento do país. Segundo, porque a cultura militar costuma privilegiar o Estado forte, material e institucionalmente, não só por ser ele um ente capaz de assegurar Forças bem constituídas, mas, inclusive, por sua capacidade para evitar a desordem, que é um dos maiores temores da instituição militar, como visto no capítulo sobre a cultura. Finalmente, para não perder prestígio e recursos humanos e materiais, especialmente, em períodos de baixa probabilidade de conflito interestatal.

A relação entre segurança, defesa e desenvolvimento está expressa em doutrinas difundidas em escolas militares e em documentos de inúmeros países, como, por exemplo, o Brasil. Após a Segunda Guerra, a doutrina de segurança nacional, disseminada em escolas como a Escola Superior de Guerra (ESG), e adotada durante os regimes militares como orientação para políticas governamentais, se baseava no binômio segurança e desenvolvimento. ${ }^{228} \mathrm{~A}$ ideia de que a segurança nacional dependia mais das capacidades do país do que apenas do seu potencial militar foi sendo constituída nos círculos militares brasileiros. A crença em práticas sociais relacionadas à uma forma de ação fundamentada em um padrão de excelência foi um dos princípios motivadores para o desenvolvimento de uma metodologia de planejamento para formulação de planos de governo, ensinada a civis e militares que frequentavam os cursos da ESG. A chamada doutrina da ESG foi formulada por seus fundadores com a seguinte visão:

“...a Segurança já não se continha nos limites da Defesa e extravasava do campo militar para impregnar-se de aspectos políticos, econômicos e psicossociais. Além disso, e neste aspecto reside o traço peculiar da ESG, verificou-se que os problemas de Segurança estavam intimamente ligados com os de

\footnotetext{
${ }^{228}$ Muitos militares, principalmente nos países em desenvolvimento, possuíam uma visão da necessidade de desenvolvimento e "modernização" do Estado. Em alguns países, eles conseguiram chegar ao poder e efetuar reformas. O caso da Turquia, sob o governo de Mustafa Kemal Ataturk, por exemplo, contribuiu para difundir a visão desenvolvimentista e modernizadora que eles defendiam (JANOWITS, 1977).
} 
Desenvolvimento, a ponto de ser impossível tratá-los como fenômenos independentes" (BRASIL, 1986, P.13).

Após os governos militares, e mais de vinte anos após a publicação do texto acima, a Estratégia Nacional de Defesa (END) brasileira reafirma essa abordagem da relação entre desenvolvimento, segurança e defesa, ao expressar claramente que:

"A Estratégia Nacional de Defesa é inseparável da estratégia nacional de desenvolvimento. Esta motiva aquela. Aquela fornece escudo para esta. Cada uma reforça as razões da outra. Em ambas, se desperta para a nacionalidade e constrói-se a Nação" (BRASIL, 2012, P.1). ${ }^{229}$

Embora a participação dos recursos militares no desenvolvimento configure-se, algumas vezes, mais premente nos países menos ricos, ela também pode ser vista em países desenvolvidos, seja pela própria dinâmica do avanço tecnológico do estabelecimento militar-industrial, seja pelo envolvimento das Forças Armadas em diversas outras áreas no âmbito doméstico. ${ }^{230}$ Além das missões de caráter estritamente militar, o corpo de engenheiros do Exército norteamericano, por exemplo, envolve-se em uma série de outras de caráter civil, tais como meio ambiente, desastres naturais, navegação interior, dragagem, hidroelétricas, etc., e, desde que foi criado, há cerca de 200 anos, "tem atendido às necessidades da Defesa e exercido um papel importante no desenvolvimento do país". 231

À essas razões mais estruturais que contribuem para Forças Armadas multifuncionais, se somam outras de caráter mais conjuntural. Em períodos de baixos níveis de tensão interestatal, como os que estão sendo vividos pela maioria dos Estados no pós-Guerra Fria, cresce a tendência de marginalização política dos militares (BUZAN e WEAVER, 2003, p.321). Esse fenômeno, associado às crises econômicas ou à necessidade de desenvolvimento do Estado, pode gerar

\footnotetext{
${ }^{229}$ A Estratégia Nacional de Defesa foi aprovada pelo Decreto Legislativo 373, de 25 de setembro de 2013. O teor completo do documento está disponível em: https://www.defesa.gov.br/arquivos/2012/mes07/end.pdf. Acesso em: 03 jun. 2013.

${ }^{230}$ O Departamento de Defesa e o Departamento do Interior, por exemplo, assinaram, em 2012, um memorando de entendimento relacionado com o desenvolvimento de energia renovável. $\mathrm{O}$ documento, na íntegra, está disponível em: http://www.defense.gov/news/d20120806idmou.pdf. Acesso em: 18 Jun.2013.

${ }^{231}$ A organização é responsável nos EUA, dentre várias outras coisas, por mais de 600 represas e a manutenção e operação de 12000 milhas de canais interiores navegáveis. Para uma visão mais abrangente da história e tarefas desenvolvidas por essa instituição, ver: http://www.usace.army.mil/Missions.aspx. Acesso em: 03 set. 2013.
} 
demandas por redução nos gastos de defesa e pela utilização das Forças Armadas em atividades não relacionadas com a sua missão básica.

Essas demandas, apesar da sua popularidade em segmentos da sociedade que questionam a utilidade dessas Forças ou defendem seu maior engajamento multifuncional, sofrem resistência de alguns setores, como visto acima, que as vê como um perigo para a sua missão básica de atuação contra ameaças, fundamentalmente, externas, que exigem dos militares, como tarefa prioritária, a preparação para o combate. A própria denominação de "atividades subsidiárias", como são tratadas as outras tarefas na legislação de alguns países, como o Brasil, espelha essa visão.

É difícil avaliar se a atuação em outras atividades tem reduzido a capacidade de combate. Concordo com aqueles autores que consideram não existirem "fortes evidências" que demonstrem a diminuição da capacidade de combate dos militares ocidentais devido ao engajamento com a diplomacia de defesa (COTTEY e FOSTER, 2004, P.74). A tendência tem sido, em muitos casos, as Forças Armadas se adaptarem, vislumbrando as possibilidades duais dessas atividades não coercitivas, que permitam que o seu cumprimento contribua para desenvolver e manter certo grau de preparação para a atuação nas missões fundamentais relacionadas com o conflito interestatal, caso sejam necessárias no futuro (SILVA, 2006).

Assim, se por um lado não existem evidências de que as tarefas ditas estariam diminuindo a capacidade combatente das Forças Armadas, por outro, na medida em que elas geram recursos adicionais ou incrementam o prestígio junto ao governo e à opinião pública nacional, contribuem ideacional e materialmente para o fortalecimento das mesmas, inclusive na obtenção de meios e possibilidades de treinamento em períodos de baixa probabilidade de conflito interestatal.

A capacidade multifuncional do Estado no âmbito doméstico se relaciona ao fenômeno da interdependência no âmbito mundial. $O$ incremento da complexidade da administração das relações entre os Estados e outras entidades da política mundial e o processo de consolidação da crença no interrelacionamento entre segurança e desenvolvimento são fatores que geram demandas para que os Estados se tornem multifuncionais, também, em relação à 
sociedade internacional, contribuindo para constituir outras práticas, crenças e normas.

Os desafios vividos por essa sociedade, sejam, por exemplo, pela debilidade de determinados países que propicia a desordem interna e seu desdobramento no âmbito externo, ou pelos problemas ambientais e desastres naturais ou, ainda, pelas ameaças transnacionais, fazem com que ela ou alguns de seus membros, muitas vezes, mobilizem recursos para tentar enfrentá-los e reduzir os danos a um nível aceitável. A mudança da natureza da segurança e sua associação ao desenvolvimento, como analisado no item referente às crenças que sustentam as práticas das instituições, contribuem ainda mais para essa faceta de atuação estatal.

A capacidade multifuncional das Forças Armadas, que concorre para sua atuação no âmbito doméstico, também possibilita as condições que incrementam a probabilidade de sua aplicação externamente, no escopo da diplomacia de defesa, inclusive nos temas relacionados ao desenvolvimento e ao fortalecimento das estruturas de segurança e defesa de outros Estados, como forma de evitar a desordem e o conflito e contribuir para a manutenção da ordem na sociedade internacional. Essa tendência recebeu um reforço com o aumento da preocupação com os Estados frágeis a partir do fim da Guerra Fria, com a crença, no cenário internacional, de que segurança e desenvolvimento estavam inter-relacionados, e com a ampliação do conceito de segurança.

Essa dinâmica vai ser enfraquecida logo após os atentados de onze de setembro de 2001, quando os EUA privilegiaram uma agenda fundamentalmente militar para reagir a esses atos. No entanto, os problemas enfrentados no Iraque e no Afeganistão modificaram esse entendimento, pois as conquistas militares não foram suficientes para se conseguir uma paz duradoura. Assim, o governo do presidente Bush passou a defender a ligação dos interesses de segurança nacional dos EUA com a diplomacia e o desenvolvimento. Essa ideia foi sendo disseminada, inclusive, no Congresso norte-americano, e discutida em relação à possibilidade dos militares cumprirem outras funções de caráter civil (BIDEN, 2008). Dessa forma, defesa, diplomacia e desenvolvimento (3D) passaram a ser considerados interdependentes na Estratégia de Segurança Nacional daquele país, e a ajuda externa, que nos anos anteriores encontrava-se em retração, tornou-se 
um item mais valorizado na agenda de política externa norte-americana (US, 2008).

Entendimento semelhante é expresso na estratégia da OTAN, de 2010. Nesse documento, considera-se que as crises e os conflitos, inclusive aqueles que possam ocorrer além das fronteiras dos países membros, se constituem em ameaças à segurança dos mesmos. As experiências no Afeganistão e nos Bálcãs mostraram a necessidade de uma abordagem ampla, que considere elementos "políticos, militares e civis" e o engajamento com outros atores internacionais, para prevenir conflitos e conduzir operações de estabilização e de apoio à reconstrução de Estados e suas instituições (OTAN, 2010).

Apesar das resistências de setores militares, as mesmas razões conjunturais apresentadas para a ampliação da atuação das Forças Armadas no âmbito doméstico contribuem para a atuação internacional em áreas relacionadas com a segurança e o desenvolvimento. ${ }^{232}$ Para uma boa parte das Forças Armadas de países em desenvolvimento, a participação nesse tipo de operações é uma oportunidade para ganhar recursos e ampliar os conhecimentos militares e as informações sobre outros Estados. ${ }^{233}$ Mesmo em países desenvolvidos, como os EUA, setores militares vêm as atividades relacionadas à ajuda humanitária e ao desenvolvimento, e à reconstrução de Estados e suas instituições, como uma forma de incrementar suas capacidades de operarem em diversos ambientes, interagirem com militares de outros países, testarem a capacidade de rápido deslocamento (como no caso de desastres naturais) etc. Além do mais, consideram que existe a possibilidade de que a participação nessas atividades contribua para a imagem humanitária dos EUA (US, 2008, P.21-22).

Desta forma, os militares vão se adaptando aos novos tempos de ameaças difusas e atuando em um espectro cada vez mais amplo, ao que nessa tese denominamos de Forças Armadas multifuncionais, ocupando espaços onde o Estado considera que elas possam ser úteis ou onde exista um vácuo deixado por

\footnotetext{
${ }^{232}$ Nos EUA, os militares, quando chamados a participar mais ativamente desse tipo de engajamento, encontravam-se às voltas com a redução de efetivos e de orçamento. Inicialmente, eles encararam essas missões como algo temporário (ZINNI, 2006:68).

${ }^{233}$ Além das vantagens acima referidas, existem outras mais específicas. O pagamento adicional recebido pelos militares quando em atividades no exterior, inclusive em forças de paz, continua sendo um incentivo econômico para a participação nas atividades relacionadas com a diplomacia de defesa (AZEVOV, 2012:4).
} 
órgãos civis. ${ }^{234}$ No âmbito das relações internacionais, a diplomacia de defesa vai se expandindo para outros campos, tais como o da (re)construção de Estado na esfera social, na segurança e no desenvolvimento. Essa adaptação tem contribuído para a institucionalização dessas práticas e a incorporação das normas a elas associadas nas estruturas militares de ensino e treinamento de muitos países, inclusive com a criação de centros específicos para preparação para missões de operações de paz e outras atividades não relacionadas com o combate. $^{235}$

Em síntese, os Estados vêm na estrutura operacional e logística das Forças Armadas um insumo importante para incrementar eficiência e eficácia da sua atuação no campo da ajuda humanitária e ao desenvolvimento, e na reconstrução de Estados e suas instituições, utilizando a coordenação dos seus recursos militares e civis, o que nos EUA e em outros países ocidentais tem sido denominado de "whole of goverment approach".

\section{4}

\section{"Whole of government approach"}

Como visto acima, o avanço do Estado para múltiplas tarefas amplifica a necessidade de coordenar as inúmeras agências e organizações do aparato estatal, de forma a ganhar eficácia e maior eficiência em sua ação. ${ }^{236}$ No campo da diplomacia de defesa, esse problema também se impõe, especialmente em relação aos países que têm uma maior atuação nessa área, como é o caso da Grã-Bretanha e, principalmente, dos EUA.

Na Grã-Bretanha, a Estratégia de Segurança Nacional, publicada em 2010, expressa que o Estado deve usar todas as suas capacidades para criar

\footnotetext{
${ }^{234} \mathrm{O}$ Lt.General William Wallace, quando confrontado com problemas de saques e vandalismo no Iraque, afirmou: "Nós treinamos para combater, mas operações para manutenção de paz é algo que nós também fazemos."(Entrevista realizada com James Kitfield, "Attack Always" no National Journal, 25 de abril de 2003. Citada no artigo de Anthony H. Cordesman. Iraq and Conflict Termination: The Road to Guerrilla Warfare? July, 2003)

${ }^{235}$ Nos EUA, por exemplo, apesar da resistência a essas atividades, as Forças Armadas têm criado doutrinas com elas relacionadas, tais como "Joint Doctrine for Military Operations Other Than War", "Peace Operations", etc.

${ }^{236}$ Os conceitos de eficácia e eficiência serão usados neste trabalho, significando, respectivamente, o cumprimento de uma tarefa e o grau de economia de recursos para cumprí-la; ou seja, uma tarefa terá sido cumprida com maior eficiência se ela tiver sido concretizada com uma maior economia de recursos.
} 
prosperidade, incrementar a influência no cenário internacional e fortalecer a segurança (UK, 2010). Os recursos humanos e materiais do âmbito da Defesa contribuem para o binômio segurança e prosperidade e para o incremento da influência britânica no mundo. Essa contribuição, segundo o mencionado documento, seria maior se esses recursos fossem usados em coordenação com aqueles utilizados pelos organismos estatais civis no engajamento internacional de defesa (UK, 2013:1).

O conceito de "whole of government approach" vai servir de orientação para o estabelecimento da Estratégia de Construção de Estabilidade no Exterior, de 2011, produzida conjuntamente pelos Secretários de Estado responsáveis pela Defesa, Negócios Estrangeiros e Desenvolvimento Internacional da Grã-Bretanha, fundamentada na crença de que a instabilidade e o conflito em outros Estados podem afetar o país, e que, "no longo prazo, a prosperidade e a segurança britânica estão entrelaçadas com a segurança e o desenvolvimento pacífico ao redor do mundo". ${ }^{237}$ A Estratégia se fundamenta em três pilares: obtenção de informações que permita um alarme antecipado em relação a elementos de instabilidade ou conflito, capacidade de rápida prevenção ou resposta aos alarmes e capacidade de atuar preventivamente nos Estados frágeis, ajudando na construção de instituições e sociedades capazes de manejar tensões (UK, 2011, P.4-5).

Em relação aos EUA, a estrutura do Departamento de Estado no pós Guerra Fria se mostrou insuficiente para atender às demandas da ampliação da agenda diplomática, nas quais temas como a promoção dos direitos humanos, governos democráticos, meio-ambiente e desenvolvimento ganharam maior destaque. Paralelamente à essa mudança, o foco nos países da Europa Central e naqueles pertencentes à antiga URSS ensejou uma alocação de pessoal e recursos para os postos naquela região, em detrimento de outras, como a América Latina e a África (US-DE OIG, 2009).

Esse problema foi agravado pelo corte nos orçamentos da diplomacia, da ajuda ao desenvolvimento e da promoção cultural. A deficiência dos órgãos civis

\footnotetext{
${ }^{237} \mathrm{O}$ conceito de estabilidade é definido como "a constituição de sistemas políticos legítimos e representativos capazes de gerenciar conflitos e realizar mudanças de forma pacífica e sociedades em que o estado de direito e os direitos humanos são respeitados, as necessidades básicas atendidas, a segurança estabelecida e as oportunidades de desenvolvimento social e econômico abertas a todos" (UK, 2011, p.5).
} 
norte-americanos foi mais acentuada em relação a vários países da África, onde abundavam problemas, tais como Estados frágeis, conflitos armados, genocídio, terrorismo, fome, miséria, tráfico de pessoas, drogas e armas. Os ataques à algumas embaixadas norte-americanas foram indícios de como isso poderia afetar diretamente os EUA. ${ }^{238}$ Mesmo assim, as deficiências do Departamento de Estado naquele continente não foram sanadas, o que fez parecer com que o governo norte-americano "estivesse mal preparado para enfrentar os desafios de um período pós Guerra Fria” (US-DE OIG, 2009).

Assim, muito antes dos ataques terroristas de 11 de setembro :

"O governo dos EUA tinha se tornado cada vez mais dependente dos militares para administrar os temas de política externa. Essa mudança foi incremental, pouco notada...Os militares simplesmente ocuparam o vácuo deixado por uma Casa Branca indecisa, um atrofiado Departamento de Estado e um Congresso distraído" (PRIEST, 2004, P.14).

Durante o Governo do presidente Bill Clinton, a estratégia de engajamento foi entendida no âmbito do Departamento de Defesa como uma autorização aos comandos unificados regionais para "moldar o ambiente", criando condições favoráveis aos interesses norte-americanos, e ir além da dimensão militar nas suas estratégias, com o propósito de manter a estabilidade regional. Embora esse processo tivesse o engajamento dos diplomatas, os comandos militares tornaramse o centro desses esforços, fundamentados, principalmente, na sua maior capacidade operacional e logística, que lhes permitia melhores condições de atender às demandas e influenciar outros atores da região (ZINNI, 2006, P.195196).

Por outro lado, o número de agências e as diversas normas legislativas ou governamentais sobre os programas de assistência de segurança, de ajuda internacional humanitária e de desenvolvimento, e de ações de estabilização e reconstrução, dificultavam a eficiência, a eficácia e o controle e acompanhamento dessas atividades, seja pelo governo, pelo poder legislativo ou, até mesmo, pela

\footnotetext{
${ }^{238} \mathrm{Em} 1998$, foram realizados atentados terroristas às embaixadas norte-americanas no Quênia e na Tanzânia. Disponível em: http://news.bbc.co.uk/onthisday/hi/dates/stories/august/7/newsid_3131000/3131709.stm. Acesso em: 22 ago.2013.
} 
sociedade em si (ISACSON e OLSON, 1998, p.vii-ix). ${ }^{239}$ Após a Guerra Fria, a constatação desse problema influenciou o governo norte-americano a tomar algumas medidas, buscando uma melhor coordenação e utilização dos recursos orçamentários.

O presidente Bill Clinton, ao sentir a importância em se adotar uma política que orientasse o uso coordenado dos diversos instrumentos à disposição do governo, principalmente, em relação aos Estados frágeis, promulgou a Diretiva Presidencial 56 (PDD-56), “Administrando Operações de Contingência Complexa", no final de 1990. Apesar do limitado sucesso, a diretiva foi um documento importante, pois apontou para a necessidade de uma abordagem mais ampla do Estado (whole of government approach) que coordenasse os recursos militares e civis no contexto, principalmente, de fortalecer Estados frágeis ${ }^{240}$ (USJFCOM, 2010).

Além disso, a partir de 1989, o Departamento de Defesa foi designado como a agência líder para a detecção e o monitoramento do movimento de narcóticos em direção ao mercado norte-americano. ${ }^{241}$ Essa medida contribuiu para que os militares norte-americanos passassem a ter um papel auxiliar importante no combate às drogas e foi um dos fatores que conduziu à ideia da reestruturação dos comandos combinados, com o propósito de torná-los uma organização interagências, como veremos mais adiante. Essa nova tarefa também foi relevante para que os diplomatas e militares norte-americanos dessem um maior destaque no tema do combate às drogas na agenda da diplomacia de defesa. $^{242}$

No final da década de 1990, as políticas visando a ajuda aos Estados frágeis, relacionadas com atividades de estabilização, manutenção da paz e reconstrução, e que envolviam a participação, principalmente, dos Departamentos

\footnotetext{
${ }^{239} \mathrm{O}$ conceito tradicional de "assistência de segurança" nos EUA considera os programas de financiamento e transferência de armamento e de treinamento, que são legislados pelo Foreign Assistance Act e pelo Arms Export Control Act, cujos recursos financeiros são aprovados pelo Congresso através da legislação que trata do orçamento anual para a ajuda internacional (ISACSON e OLSON, 1998, p.ix).

${ }^{240} \mathrm{O}$ termo "operações complexas" tentava dar a conotação de que essas operações tinham um caráter misto, que juntava problemas de segurança com humanitários (ZINNI, 2006, p.68).

${ }^{241}$ Disponível em: http://www.rand.org/content/dam/rand/pubs/notes/2007/N3275.pdf. Acesso em 08 mar.2014.

${ }^{242}$ Para uma visão das drogas como um problema local, nacional e global, ver: MARES, David R. Drug Wars and Coffeehouses. The Political Economy of the International Drug Trade. Washington, DC:CQ Press, 2006.
} 
de Estado e Defesa e da Agência dos Estados Unidos para o Desenvolvimento Internacional, passaram a sofrer um processo de mudanças. O problema desses Estados como uma ameaça à segurança nacional dos EUA já fazia parte das preocupações das estratégias de segurança nacional deste país, que também apontavam para uma maior coordenação dos recursos militares e civis, de modo a se atingir um melhor desempenho da ação estatal ${ }^{243}$ (US, 1998, p.6). No entanto, a crença de que Estados frágeis podiam constituir uma ameaça aos objetivos de segurança dos EUA, ao se tornarem fonte de instabilidade e conflito, e campo fértil para os crimes transnacionais, terrorismo, tráfico de armas, narcóticos, pessoas etc., vai ser amplamente reforçada após os atentados terroristas de 11 de setembro de 2001 e com as experiências adquiridas durante as intervenções no Iraque e no Afeganistão.

Essas intervenções mostraram que a superioridade militar combatente, embora pudesse garantir uma rápida vitória militar contra forças armadas regulares, tinha dificuldades contra ações de guerra irregular, como o conflito no Vietnã já havia demonstrado, e com a administração das condições pós-conflito, que garantisse a constituição de um Estado capaz de prover sua própria segurança. Desta forma, fortalecia-se a crença na necessidade da mudança de uma visão puramente estratégico-militar para uma mais abrangente, relacionada com os vários aspectos da segurança, concretizada através de práticas sociais que integrassem os esforços civis e militares, inclusive nos campos econômicos, sociais e ambientais.

Assim, no campo da Defesa, foi sendo constituída a ideia da necessidade de incrementar a participação em outras áreas normalmente de atuação civil, em que os militares já tinham tido experiência passada, mas que, contudo, havia sido relegada a um segundo plano, devido à preocupação com a preparação para o combate durante a Guerra Fria. ${ }^{244}$ Esse processo culminou com a Diretiva 3000.05, de 28 de novembro de 2005, do Departamento de Defesa, que estabeleceu que esse tipo de atividade, denominada, genericamente, operação de estabilização e reconstrução, deveria ter a mesma prioridade que as missões de

\footnotetext{
${ }^{243}$ Alguns militares norte-americanos propõem que a integração das diversas organizações governamentais seja realizada tendo como base o modelo militar de atuação combinada nos níveis estratégicos, operacional e tático (ZINNI, 2006:158-1750).

${ }^{244}$ Os militares norte-americanos, por exemplo, já haviam desempenhado funções administrativas civis em diversas áreas liberadas pelos aliados durante a Segunda Guerra Mundial, na Europa e no Japão.
} 
combate, e que integrar os esforços civis e militares seria crucial para o seu sucesso. $^{245}$

O principal objetivo dessa operação foi definido no documento como o restabelecimento da ordem nos Estados ou regiões, "que contribua para os interesses e valores dos EUA". As ações mais imediatas deveriam ser realizadas para prover segurança, serviços essenciais e ajuda humanitária à população. Dessa forma, contribuindo para que o Estado pudesse ser capaz de garantir sua própria segurança, desenvolver a democracia e o estado de direito, a sociedade civil, instituições fortes e uma economia de mercado viável. Nesta diretiva, no item 4.5, é estabelecido que o Departamento de Defesa deve continuar a "liderar e apoiar o desenvolvimento das equipes civis-militares que são fundamentais para esse tipo de operação" (US-DoD, 2005, p.2).

Aos 7 de dezembro de 2005, alguns dias após a divulgação do documento, o presidente George W. Bush aprova a Diretiva NSPD-44, que trata da coordenação dos esforços do governo norte-americano para a reconstrução e estabilização de Estados frágeis. Nesse documento, é atribuído ao Departamento de Estado a liderança do desenvolvimento de estratégias, em harmonização com a ação militar, e a coordenação desses esforços com outras agências, principalmente com a Defesa. O programa, que poderia ser chamado de "anti-Estado frágeis", foi assim apresentado na Diretiva:

\begin{abstract}
"Os Estados Unidos têm um interesse significativo em incrementar sua capacidade de auxiliar na estabilização e reconstrução de países ou regiões, especialmente aqueles em risco ou em transição de conflitos ou guerras civis, e ajudá-los a estabelecer um caminho sustentável para a construção de sociedades pacíficas, democracias e economias de mercado. Os Estados Unidos devem trabalhar com outros países e organizações para prevenir o fracasso do Estado, evitá-lo sempre que possível, e responder rápida e eficazmente, quando necessário e adequado para promover a paz, a segurança, o desenvolvimento, as práticas democráticas e as economias de mercado e do Estado de Direito. Esse trabalho deve ter como objetivo permitir que os governos no exterior tenham a capacidade de exercer a soberania sobre seus próprios territórios e impedir que
\end{abstract}

\footnotetext{
${ }^{245}$ A Diretiva define operações de estabilização como as atividades militares e civis, no espectro entre a paz e o conflito, necessárias para estabelecer ou manter a ordem nos Estados ou regiões. Esse conceito vai ser ligeiramente modificado na Instrução de mesmo número, publicada em 2009, que esclarece que o termo engloba várias atividades realizadas conjuntamente com outros "instrumentos do poder nacional" para manter a ordem, prover serviços essenciais de governo, reparar infra-estrutura e prover ajuda humanitária. Disponível em: htttp://faculty.nps.edu/dl/HFN/documents/DoD_Directive_d300005p.pdf. Acesso em: 06 jun.2013.
} 
estes sejam utilizados como uma base de extremistas, terroristas, grupos de crime representem uma ameaça à política externa dos EUA, segurança ou interesses econômicos (US-NSPD 44, 2005). operações ou refúgio seguro para organizado, ou outros que

Esse corpo normativo vai orientar e legalizar a atuação dos militares norteamericanos em atividades relacionadas com o desenvolvimento e a ajuda humanitária, avançando por áreas, normalmente, de atuação civil. No âmbito militar, as resistências internas a esse tipo de atividade perderam consistência, na medida em que elas ganharam uma importância semelhante às atividades de combate e foram associadas à segurança nacional, com implicações para a sociedade internacional. Nesse contexto, a cultura militar do cumprimento da missão e da unidade de comando e de esforço contribuiu para a produção de um corpo doutrinário de documentos e de mudanças organizacionais, que estabeleceram padrões de práticas, que favoreciam os objetivos a serem alcançados com a visão mais abrangente de segurança e da abordagem do "whole of government approach." 246

No campo normativo, foram produzidos pelas organizações militares, especialmente pela Junta de Chefes de Estado-Maior, manuais relacionados com essas práticas, que incluíam as ações coordenadas entre militares e civis em áreas, tais como: reconstrução e estabilização, apoio militar para serviços essenciais e infraestrutura crítica, estabilização econômica, apoio à governança, eleições e mídia, estado de direito e reforma do setor de segurança (US-JFCOM, 2010). No campo organizacional, uma das principais medidas foi a adaptação de comandos combinados regionais para incorporar representantes de agências civis e de outros órgãos governamentais, como no Comando Sul dos EUA, ou a criação de um novo Comando na África, já nos moldes de interagência. ${ }^{247}$

No Comando Sul, o Almirante James G. Stavidris, que conduziu sua reorganização, acreditava que os problemas que afetam a segurança requeriam uma nova concepção que não estivesse fundamentada nas tradicionais noções da separação nítida entre guerra e paz, e da divisão entre diplomacia, conduzida pelo Departamento de Estado em tempo de paz, e da força a ser aplicada pelo

\footnotetext{
${ }^{246}$ Os militares norte-americanos definem a unidade de ação como a sincronização, coordenação e/ou integração das atividades das organizações governamentais ou não governamentais com as operações militares para se lograr a unidade de esforço (US-JFCOM, 2010:I-1).

${ }^{247}$ Organizacionalmente, essas estruturas interagências são denominadas Joint Inter-Agency Task Force (JIATF) ou Joint Inter-Agency Coordination Group (JIACG) (ZINNI,2006, P.170).
} 
Departamento de Defesa em períodos de conflito armado. Essa mudança exigiria uma maior integração entre as agências governamentais, setor privado e coalizões (STAVIDRIS, 2007). Nessa visão, se as fronteiras entre guerra, paz, diplomacia e desenvolvimento haviam se tornado porosas e difíceis de serem distinguidas, os vários atores civis e militares que atuavam na cena internacional precisariam trabalhar juntos para alcançar melhores resultados (GATES, 2008).

Assim, o aparato militar modificou sua estrutura organizacional para transformar-se, além de num comando preparado para o combate, em um "Joint Interagency Security Command", integrando os esforços entre os recursos militares e as agências civis, inclusive com oficiais de ligações de outros países, que nele se inserem sem maiores problemas, graças à cultura e doutrina semelhantes que são disseminadas nas escolas militares. A partir dessa alteração, o comandante militar passou a ter um diplomata como seu vice para assuntos civis. Essa reestruturação foi considerada um sucesso pelo ex-Secretário de Defesa Robert M.Gates, no discurso de transferência do comando do almirante James Stavridis, em junho de 2009, a quem elogiou por ter demonstrado uma combinação única de "visão estratégica com capacidade diplomática" ${ }^{248}$

\begin{abstract}
"Desde o início de seu mandato no Comando Sul, o Almirante Stavridis tem fomentado um espírito de cooperação interinstitucional e internacional, que reflete a realidade do pós-Guerra Fria do século 21. Ele fez no Comando Sul a encarnação do que hoje é chamado de "poder inteligente", com base na plena força da nossa nação e de nossos parceiros, para aumentar a segurança, a liberdade e a prosperidade desta parte do mundo. Durante os quase três anos que ficou à frente do Comando Sul, ele compreendeu que a mistura de desafios de segurança enfrentados nesta região - narcóticos, corrupção, gangues, sequestros, e muito mais - não se presta a soluções militares, como tradicionalmente entendida ou praticada. Assim, ele não apenas redesenhou os organogramas deste comando, como promoveu uma profunda modificação na forma de enfrentar os desafios e na reforma da cultura da instituição" (GATES, 2009).
\end{abstract}

O Comando da África já nasceu com esse novo enfoque. Criado em 2007, com responsabilidade sobre todo o continente, exceto o Egito, ele mantém relações com 53 países da região. ${ }^{249}$ Desde a sua criação, adotou o sistema interagência, contando com diplomatas e representantes de 13 departamentos e

\footnotetext{
${ }^{248} \mathrm{O}$ discurso completo do Secretário está disponível em: http://www.defense.gov/speeches/speech.aspx?speechid=1363. Acesso em: 06 mai.2013.

${ }^{249}$ Em face da dificuldade de encontrar um país africano que aceitasse a sede do Comando no seu território, ele se encontra sediado em Stuttgart, na Alemanha, mesma cidade onde se localiza o Comando Combinado para a Europa (EUROCOM).
} 
agências do governo norte-americano, que tratam de temas relacionados com comércio, desenvolvimento, ajuda internacional, etc. ${ }^{250}$ Sua força de trabalho conta com cerca de 2000 funcionários militares e civis e um orçamento, em 2010, de cerca de US\$ 300 milhões. Ele tem uma estrutura privilegiada em tamanho e recursos em relação ao setor do Departamento de Estado que trata da África, que possui cerca de 80 funcionários (REVERON, 2010).

Em síntese, a expansão e o aprofundamento da diplomacia de defesa, especialmente em relação à superpotência militar, na qual esse fenômeno tem uma maior amplitude, tem gerado críticas de diversos setores. Assim, muitos alegam a necessidade de fortalecer o Departamento de Estado e outras agências, como forma de reduzir a presença dos militares em áreas consideradas do âmbito civil, o que, entretanto, significa incrementar gastos em tempos de crise financeira e orçamentos contidos. Dessa forma, as Forças Armadas aparecem como uma solução natural alicerçada na sua capacidade logística, organização e cultura de cumprimento da missão, que facilita, sob muitos aspectos, a execução das atividades nesse âmbito. Assim, apesar das críticas, alguns órgãos de fiscalização governamental destacam as vantagens da ampliação dessa atuação, inclusive da reconfiguração dos comandos militares. O Escritório do Inspetor Geral (EIG), órgão responsável pela verificação do desempenho do Departamento de Estado, ao apontar os problemas desse Departamento em relação à África, em relatório de 2009, afirma:

"Em 2007, surge um novo ator bem construído na cena africana: o Comando Militar da África... e os militares ocupam o vácuo deixado pela falta de recursos para a ajuda ao desenvolvimento e para a diplomacia pública" (US-OIG, 2009, P. 4-8).

Embora medidas para fortalecer o Departamento de Estado e outras agências civis tenham sido tomadas pelo governo norte-americano, principalmente após os atentados de 11 de setembro, muitos problemas ainda persistem. As palavras do então Secretário de Defesa, Robert Gates, expressam essa situação, ao afirmar que:

\footnotetext{
250 Os objetivos e programas do US Africa Command podem ser vistos em: http://www.africom.mil/AboutAFRICOM.asp. Acesso em: 04 mai. 2012.
} 


\begin{abstract}
"Deficiências, no entanto, permanecem. Tornou-se claro que as instituições civis dos Estados Unidos relacionadas com a diplomacia e o desenvolvimento sofreram, por muito tempo, com a falta de recursos humanos e financeiros, principalmente, quando comparado ao que gastamos com os militares e, mais importante, em relação às responsabilidades e desafios que a nossa nação tem ao redor do mundo. $\mathrm{O}$ desafio que enfrentamos atualmente se traduz em como desenvolver a melhor forma de integrar os recursos civis e militares, os parceiros internacionais e o setor privado. Onde nosso governo logra juntar esses recursos para apoiar outros parceiros na cena internacional, os resultados têm sido promissores. O que é, praticamente, uma certeza, é a necessidade de trabalharmos com e através dos governos locais para evitar a próxima insurreição, resgatar o próximo Estado prestes a falir, ou evitar o próximo desastre humanitário" (GATES, 2008).
\end{abstract}

Ao mesmo tempo que o Departamento de Estado busca incrementar sua eficiência e o "poder civill", e avançar nos instrumentos de coordenação entre os militares e os diversos órgãos governamentais relacionados com a ajuda humanitária e de desenvolvimento internacional, o Departamento de Defesa continua expandindo sua atuação nesse campo. O relatório do United States Government Accountability Office (GAO), de 2012, sobre essa atividade, mostra que este Departamento aumentou a ênfase em programas relacionados à assistência humanitária, inclusive em apoio a desastres naturais, e que no período de 2005 a 2010 neles aplicou cerca de US\$ 383 milhões.

O GAO reconhece que as ações da Defesa nesse setor têm resultado em práticas positivas, tais como: o alinhamento dos projetos com os objetivos estratégicos dos órgãos governamentais, estabelecendo processos para a execução desses projetos, e o desenvolvimento de esforços para coordenar suas ações com o Departamento de Estado e a agência responsável pela ajuda internacional, inclusive incluindo representantes desses órgãos nos comandos militares regionais. Por outro lado, o GAO mostra falhas na administração dos dados concernentes aos recursos alocados aos projetos e limitada orientação para a atividade e avaliação dos resultados dos programas. No relatório são elencadas algumas recomendações: a ampliação da coordenação entre os órgãos envolvidos, a melhoria das orientações e da administração dos dados, inclusive entre as agências, e o estabelecimento pelo Congresso, com maior clareza, do papel do Departamento de Defesa na atividade de ajuda humanitária e ao desenvolvimento (US, 2012, P.1-4). 
Desse modo, a tendência aponta para a aceitação da expansão e aprofundamento das tarefas relacionadas com a diplomacia de defesa, o que reforça a necessidade de coordenação entre os órgãos responsáveis pelas Relações Exteriores e pela Defesa, de modo a evitar "diplomacias paralelas" e, também, tentar implementar uma unidade de esforço, que permita um desempenho eficaz e mais eficiente dos recursos do Estado na cena internacional.

\section{5}

\section{A coordenação da diplomacia}

Como visto anteriormente, a expansão da atuação do Estado para outras áreas, no âmbito doméstico, e o crescimento da interdependência são tendências que contribuem para o incremento da complexidade da administração das relações entre os Estados e outras entidades que atuam na política mundial (WATSON, 1982), complicando o processo de formulação, execução e acompanhamento dos objetivos estatais relacionados com as relações internacionais, na medida em que aumenta o número de atores governamentais que delas participam. ${ }^{251}$

Assim, a diplomacia profissional, embora mantenha um papel central na realização das funções da diplomacia, vem tendo dificuldades em manter o controle da condução das relações internacionais, causadas pelo crescimento do número de outros atores do governo que também realizam essas funções, principalmente devido à crescente necessidade de gerenciamento de assuntos técnicos, que obrigam o diplomata a ceder espaço para o especialista (HILSMAN, 1971; BULL, 1995; HILL, 2003, PINHEIRO e MILANI, 2012). Os ministérios das Relações Exteriores tentam se adaptar, por um lado, incluindo nas suas estruturas organizacionais setores responsáveis por temas específicos, tais como, economia, comércio, meio-ambiente etc., ou aceitando nas embaixadas adidos oriundos de outras organizações governamentais. ${ }^{252}$ Esta última medida, no

\footnotetext{
${ }^{251}$ O processo de controle das burocracias no Século XXI, em um contexto no qual elas se tornam "redes com múltiplas organizações ", é um dos maiores desafios que o Estado tem que enfrentar (KETTL, 2008, P.373).

${ }^{252}$ No caso do Brasil, por exemplo, a estrutura organizacional do ministério das Relações Exteriores foi ampliada para atender a temas econômicos, meio-ambiente, ciência e tecnologia, direitos humanos e sociais, etc. ( Brasil. Decreto $\mathrm{n}^{\mathbf{0}}$ 7.304, de 22 de setembro de 2010. Aprova a Estrutura Regimental e o Quadro Demonstrativo dos Cargos em Comissão e das Funções
} 
entanto, dificulta o controle e a coordenação, já que esses agentes, normalmente, mantêm lealdade às suas organizações de origem.

Desta forma, a complexidade da diplomacia gera desafios na implementação de mecanismos de coordenação destinados à obtenção de algum grau de coerência nas práticas diplomáticas. Essa necessidade se faz mais necessária, principalmente, em relação ao âmbito da Defesa, pela intensidade e variedade das práticas diplomáticas relacionadas com esse campo de atividade. As características da diplomacia de defesa, o seu grau de institucionalização e as capacidades logísticas e operacionais das Forças Armadas, especialmente no caso das potências militares, como visto na análise anterior, possibilitam uma autonomia relativa dos seus principais atores nas relações internacionais: os ministérios da Defesa e as Forças Armadas.

Essa autonomia se dá, por exemplo, nos EUA, conforme visto no capítulo anterior, onde os Secretários de Defesa, além de viajarem pelo mundo discutindo temas específicos da sua organização, também tratam de temas inerentes à política externa (STEVENSON, 2007). Os comandantes dos comandos regionais norteamericanos, igualmente, têm uma interação com os países da sua área de jurisdição que vai além dos temas de Defesa e, muitas vezes, tentam operar independentemente "em direto conflito com a política e os programas das embaixadas" (STEPHENSON, 2012, P.222).

A variedade de mecanismos bilaterais ou multilaterais relacionados com a diplomacia de defesa, a expansão e o seu aprofundamento para outros setores, tais como a ajuda humanitária, o desenvolvimento, a estabilização e a reconstrução de Estados frágeis, dificultam a coordenação. Esse fenômeno se dá, também, no âmbito interno da Defesa, pois as Forças Armadas compartilham mecanismos específicos com várias das suas congêneres de outros Estados, como descrito no Capítulo 3, o que lhes permite uma certa autonomia em relação ao ministério ao qual estão subordinadas.

Nesse contexto, uma tensão emerge, por um lado, pela possibilidade de conflitos entre essa autonomia e a necessidade de subordinação da diplomacia de defesa aos objetivos de política externa, a fim de garantir um grau de coerência

Gratificadas do Ministério das Relações Exteriores, e dá outras providências). Disponível em: http://www.planalto.gov.br/ccivil_03/_Ato2007-2010/2010/Decreto/D7304.htm. Acesso em:17 jun.2013. 
nesta política; e, por outro, pela necessidade de coordenar, e até mesmo limitar, a participação dos agentes estatais ligados à Defesa nas tarefas relacionadas com as áreas da ajuda internacional, normalmente associadas com as agências civis.

Não existe uma fórmula universal para administrar a coordenação entre os ministérios das Relações Exteriores e da Defesa e outros órgãos e atores. Alguns países possuem na estrutura desses ministérios setores responsáveis por essa coordenação, criados mais recentemente ou já consolidados nas estruturas organizacionais. O Brasil, por exemplo, se encontra no primeiro caso, pois apenas em 2010, com a reformulação do ministério das Relações Exteriores, foi criada, junto ao Gabinete do Secretário Geral, uma Coordenação-Geral de Assuntos de Defesa.

No caso dos EUA, onde essas práticas têm um caráter mais abrangente, essa coordenação há muitas décadas, e o Departamento de Estado possui, na sua estrutura organizacional, o Escritório para Assuntos Político-Militares, que é o setor responsável por integrar as questões diplomáticas relacionadas com a Defesa, que tem como tarefa "prover a orientação política em áreas de segurança internacional, assistência de segurança, operações militares, estratégia e planos e comércio de Defesa", sendo o principal canal com o Departamento de Defesa. ${ }^{253}$ A esse Escritório, cabe, ainda, dentre outras atividades, negociar acordos militares, facilitar a realização de operações no Exterior, fornecer assessores políticos para os serviços militares e comandos combinados, promover a estabilidade regional por meio dos programas de assistência de segurança, e regular as transferências de armamento dos EUA, contribuindo para a Defesa, o planejamento e a condução dos temas "político-militares".

Um dos setores do Escritório coordena o programa de assessores para política externa que provê pessoal especializado para atuar junto ao Departamento de Defesa nas questões relacionadas com temas interagências. Em 2013, aproximadamente cem assessores de política externa ${ }^{254}$ se encontravam distribuídos pelas organizações militares, inclusive nos comandos combinados

\footnotetext{
${ }^{253}$ Para maiores informações sobre o Escritório para Assuntos Político-Militares, inclusive seu posicionamento no organograma do Departamento de Estado, ver: http://www.state.gov/t/pm/. Acesso em: 17 Jun. 2013.

${ }^{254}$ Os assessores de política externa são conhecidos pela sigla inglesa POLADs.
} 
regionais. ${ }^{255} \mathrm{O}$ Secretário Assistente para Assuntos Político-Militares do Departamento de Estado tem como interlocutor na Defesa o Secretário Assistente para os Assuntos de Segurança Internacional.

Cabe, também, ao Departamento de Estado a responsabilidade legal de supervisionar a maioria dos programas relacionados com a cooperação internacional. Assim, as embaixadas contam com os escritórios de cooperação de segurança, que são os setores a quem cabe essa tarefa no âmbito local ou regional. Da mesma forma, a responsabilidade pela coordenação dos esforços do governo norte-americano nas tarefas de reconstrução e estabilização é desse Departamento. $^{256}$ A Diretiva Presidencial de Segurança Nacional 44 estabelece, porém, que os Secretários de Estado e de Defesa devem “ desenvolver uma moldura de plena coordenação nessas tarefas", inclusive, harmonizando os planejamentos "civis" e militares. A legislação norte-americana permite ao presidente prover essa assistência para países ou regiões que sejam considerados em risco ou em transição pós-conflito, que necessitem ajuda para a reconstrução, desde que considere ser do interesse da segurança nacional e informe ao Congresso com cinco dias úteis de antecedência. ${ }^{257}$ O Congresso, por sua vez, reconhece a liderança do Departamento de Estado neste mister e exige ser mantido informado sobre os esforços que esse órgão venha a fazer para incrementar a Diretiva 3000.05, incluindo medidas que mostrem os obstáculos, os desafios e as possíveis soluções para integrar o apoio interagências nas operações de reconstruções e estabilização.

Em relação ao Departamento de Defesa, existe, na sua estrutura, um órgão específico para tratar dos diversos programas. Subordinado ao escritório do Assistente do Secretário de Defesa para Assuntos de Segurança Internacional, encontra-se a Agência de Cooperação de Defesa e Segurança. Esta tem como missão principal a direção, supervisão e acompanhamento dos programas

\footnotetext{
255 Para maiores detalhes sobre esse órgão, ver : http://www.state.gov/t/pm/polad/index.htm. Acesso em: 17 Jun.2013.

${ }^{256}$ O Departamento de Estado criou, em junho de 2004, o Escritório Coordenador para a Reconstrução e Estabilização (S/CRS) para uma melhor coordenação dessa atividade entre agências governamentais (US-JFCOM, 2010, p.i).

${ }^{257} \mathrm{O}$ teor completo das modificações autorizadas pelo Congresso norte-americano pode ser visto no Relatório 110-652 do Committee on Armed Services House of Representatives. Duncan Hunter National Defense Authorization Act for Fiscal Year 2009, Title XVI. Pp-479-481.

Disponível em: http://www.gpo.gov/fdsys/pkg/CRPT-110hrpt652/html/CRPT-110hrpt652.htm. Acesso em: 10 jun.2013.
} 
relacionados com a cooperação de segurança, inclusive aqueles relacionados à ajuda humanitária e desastres naturais, e outros, de responsabilidade do Departamento de Estado, mas que são executados através dela, em íntima atuação com as embaixadas, os comandos combinados regionais e as Forças Armadas, que também possuem suas estruturas associadas às atividades da diplomacia de defesa. ${ }^{258}$ Além desses órgãos, o Estado-Maior Conjunto também tem um papel de assessoramento, coordenação e de produção de normas e regras relacionados ao tema. A essa estrutura se somam outras organizações militares e agências que contribuem para atividades relacionadas com o ensino, a logística etc.

Os EUA utilizam, ainda, um mecanismo chamado "PolMil Talks" para conversações sobre temas político-militares com outros países. Essa instância, normalmente, de caráter bilateral e com periodicidade definida, reúne representantes militares e civis dos Departamentos de Estado e de Defesa com os seus contrapartes de outros Estados, na tentativa de garantir a coordenação e a coerência nos temas tratados. ${ }^{259}$

Em relação às ONGs, o governo norte-americano também tem tentado articular alguma forma de coordenação. Em 2005, foram mantidas conversações entre a InterAction, que representa mais de 180 dessas organizações, o Departamento de Estado, a Junta de Chefes de Estado-Maior e a Agência dos EUA para o Desenvolvimento Internacional, que resultaram nas "diretrizes para as relações entre as Forças Armadas norte-americanas e as organizações humanitárias não-governamentais em ambientes hostis ou potencialmente hostis". 260

No âmbito normativo de mais alto nível, como visto anteriormente, o Departamento de Estado publicou, em 2010, o documento chamado "Liderando Através do Poder Civil - O Primeiro Relatório Quadrienal da Diplomacia e do Desenvolvimento", com o propósito de coordenar as ações diplomáticas, inclusive

\footnotetext{
258 Alguns desses programas de responsabilidade do Departamento de Estado, mas, executados pela Defesa são o Foreign Military Financing $(F M F)$, o International Military Education and Training (IMET) e o Foreign Military Sales (FMS). Para uma visão geral sobre a Agência, ver: http://www.dsca.mil. Acesso em: 23 set.2013.

${ }^{259}$ Com o Brasil, as PolMil talks são realizadas entre os Departamentos de Estado e de Defesa e os ministérios da Defesa e das Relações Exteriores brasileiros, normalmente, a cada dois anos. Elas têm por objetivo tratar sobre temas de segurança e defesa, seja no âmbito da agenda de segurança internacional, seja nos aspectos do relacionamento bilateral entre os dois países.

${ }_{260} \mathrm{O}$ texto completo dessas diretrizes está disponível em:

http://www.usip.org/sites/default/files/guidelines_handout.pdf. Acesso em: 31 jan.2014.
} 
aquelas relacionadas com a ajuda ao desenvolvimento. Uma das principais razões alegadas para a sua confecção foi a necessidade de se buscar o melhor emprego dos recursos em época de crise financeira. Nota-se, no entanto, que existe uma preocupação do Departamento de Estado com a liderança civil na diplomacia e na ajuda ao desenvolvimento. De acordo com a Secretária de Estado, Hillary Clinton:

\begin{abstract}
"Os desafios que nós enfrentamos - a proliferação nuclear, pandemias globais, alterações climáticas e o terrorismo - são mais complexos do que nunca. Não é suficiente apenas lidarmos com eles. Devemos ficar à frente dele. Para isso, vamos incrementar o nosso poder civil, representado pela força combinada de civis que trabalham em conjunto em todo o governo dos EUA para praticar a diplomacia, realizar projetos de desenvolvimento, e prevenir e responder às crises. Muitas diferentes agências contribuem para estes esforços hoje. O seu trabalho, contudo, pode tornar-se mais unificado, focado e eficiente" (US-QDDR, 2010).
\end{abstract}

Na Grã-Bretanha, segundo o Departamento de Defesa, é primordial a coordenação entre este departamento, o órgão responsável pelas relações exteriores e o departamento de desenvolvimento internacional, de modo a se obter sinergia no campo diplomático, com o propósito de influenciar comportamentos e contribuir para evitar crises e conflitos. ${ }^{261}$ A Estratégia de Construção de Estabilidade no Exterior, mencionada anteriormente, elaborada pelas três instituições governamentais, é um passo na direção de uma melhor coordenação. O governo britânico decidiu, ainda, que a diplomacia de defesa e o engajamento de segurança passassem a ser coordenados conjuntamente entre o ministério responsável pelas Relações Exteriores e o da Defesa. Como resultado, uma estratégia comum foi preparada pelos dois órgãos, a fim de se lograr uma maior troca de experiência e uma melhor coordenação, denominada Engajamento Internacional de Defesa, para cuja administração foi criada uma estrutura compartilhada entre seus membros, com a participação de outros departamentos (UK, 2013, P.4-5).

\footnotetext{
${ }^{261}$ UK, Ministry of Defense. Paper N.1 Defense Diplomacy. Director General Corporate Communication, London.
} 


\section{6}

\section{Conclusão}

A possível "desmilitarização da defesa" e a "militarização da diplomacia" são duas faces da mesma moeda e estão intimamente interligadas. $\mathrm{O}$ aumento das demandas da sociedade tem contribuído para a constituição do Estado multifuncional, que, muitas vezes, visualiza nas capacidades logísticas e operacionais das Forças Armadas um importante recurso para ajudá-lo nas suas inúmeras tarefas, tanto no âmbito doméstico, quanto no internacional. Neste contexto, a diplomacia de defesa tem tido uma tendência para a expansão e aprofundamento das suas atividades, ampliando sua participação em forças de paz e em tarefas de (re)construção, estabilização e ajuda humanitária e ao desenvolvimento.

O desenvolvimento da diplomacia de defesa se dá em maior grau nos países ocidentais mais ricos, especialmente os EUA, que são a superpotência militar, em face, inclusive, do processo de consolidação da crença de que desenvolvimento e segurança e defesa estão inter-relacionados. Os militares norteamericanos vêm o cumprimento eficiente e eficaz das tarefas que lhes foram atribuídas como uma contribuição ao "whole of government approach", enquanto os críticos visualizam aquilo que denominam "militarização da diplomacia”. Essa "militarização" é contestada pelo Departamento de Defesa e contextualizada por outros órgãos do governo norte-americano, que consideram benéfica a atuação dos militares e argumentam que as normas existentes dão ao Departamento de Estado a liderança no processo, e que os embaixadores nos países onde os militares atuam têm o poder de supervisioná-los e, inclusive, afastá-los do staff das embaixadas.

Assim, as Forças Armadas vêm se adaptando para tornarem-se multifuncionais, sem perderem sua capacidade de cumprir suas missões fundamentais, a fim de contribuírem para a eficiência e eficácia de um Estado cada vez mais exigido, em face das demandas crescentes das sociedades domésticas e internacional e das mudanças no cenário político-estratégico internacional. Essa adaptação tem ajudado a incrementar seu prestígio e evitar, em alguns casos, reduções drásticas nos seus efetivos e meios materiais, e, até 
mesmo, angariar recursos adicionais no cumprimento de tarefas "subsidiárias", sem maiores indícios, até agora, de perda de capacidade combativa.

Em relação à coordenação, os Estados têm, normalmente, reagido às tensões entre a diplomacia de defesa e a diplomacia desenvolvida pelos ministérios das Relações Exteriores por meio de normas, inclusive aquelas que estabelecem a competência destes últimos nos temas de política externa, com o estabelecimento de estratégias comuns e mecanismos de coordenação, e com a criação de funções nas estruturas dessas organizações nas quais militares e diplomatas possam trabalhar juntos. No entanto, essas iniciativas não solucionam todos os problemas, já que a complexidade da diplomacia contemporânea, da qual a expansão e o aprofundamento da diplomacia de defesa são sintomas, tornam cada vez mais difícil o papel coordenador dos ministérios das Relações Exteriores e dos próprios Estados. 


\section{Conclusão}

\section{1}

\section{Introdução}

Esta tese iniciou-se com uma constatação: a existência de um conjunto de práticas sociais no âmbito da Defesa disseminadas entre os Estados e outras entidades que atuam na política internacional, e com uma indagação: qual seria o papel dessas práticas na sociedade internacional? Ao final desse percurso, algumas conclusões sobre os dois pontos iniciais podem ser apontadas. Primeiramente, sobre as práticas sociais em particular e sua institucionalização. Em seguida, sobre a relação das mesmas com o conceito de sociedade internacional.

\section{2}

\section{A institucionalização no âmbito da diplomacia de defesa}

No Capítulo 3 e, adicionalmente, no Capítulo 6, foi analisado um amplo conjunto de práticas pelas quais os países interagem no âmbito da Defesa, dentre as quais se destacam os mecanismos bilaterais e multilaterais. Embora entre países existam algumas diferenças quanto àquelas que são abrangidas pelo conceito de diplomacia de defesa, há um núcleo que, normalmente, é comum nas relações entre os Estados, ainda que em diferentes níveis e graus.

A troca ou designação de adidos militares constitui uma das práticas mais antigas, comuns e visíveis da diplomacia de defesa. Eles estão presentes na maioria das embaixadas espalhadas pelo mundo, formando uma comunidade diplomática militar nos países onde são acreditados, constituindo-se nos representantes dos Ministérios da Defesa e das Forças Armadas e em alguns dos principais interlocutores no diálogo diplomático no âmbito da Defesa.

Existem, ainda, as práticas relacionadas ao aprimoramento da capacidade militar de outros Estados e à interoperabilidade, tais como os exercícios militares, 
troca de pessoal, treinamento e cursos, fornecimento de equipamentos, etc. Os EUA lideram nesse campo, possuindo centenas de programas de treinamento e venda de equipamento envolvendo mais de 200 países e organizações. ${ }^{262}$ Outras práticas estão relacionadas com o controle civil das Forças Armadas, tais como cursos para civis, assessoria civil para a Defesa, seminários sobre o tema para militares, etc. Há aquelas que têm como propósito apoiar membros mais frágeis da sociedade internacional, seja aprimorando capacidades para atuar em forças de paz, seja na assistência humanitária e ao desenvolvimento, ou na reconstrução de Estados e suas instituições. Finalmente, existem aquelas voltadas para a construção de alianças, acordos e parcerias estratégicas, criação e manutenção de mecanismos regionais ou bilaterais que permitam o diálogo diplomático de Defesa entre os países ou que atendam a interesses específicos.

As interações relacionadas com a diplomacia de defesa, geralmente, são normatizadas através de documentos no âmbito do Congresso, governo ou de entidades que atuam na política internacional e detalhados através de documentação no âmbito da Defesa. Esse conjunto de práticas, crenças e normas, normalmente, é apoiado por estruturas burocráticas e rotinas que provêm os recursos humanos e materiais e estabelecem o status, inclusive legal, de uma determinada atividade, contribuindo para o que Holsti (2004) considera como a constituição de uma instituição da sociedade internacional. Nos Estados, os ministérios da Defesa e as Forças Armadas, com os seus recursos materiais e humanos, são as organizações que dão o apoio logístico necessário para o desenvolvimento das atividades, algumas delas em comum acordo com os ministério das Relações Exteriores, como é o caso dos escritórios dos adidos militares nas embaixadas. No caso de outras entidades, esse apoio é usualmente conjugado entre elas e os Estados-membros que a compõem.

Nas estruturas dos Ministérios da Defesa e das Forças Armadas é comum existirem setores responsáveis pelas relações internacionais que administram as diversas práticas bilaterais e multilaterais relacionadas com a diplomacia de defesa. Nos ministérios das Relações Exteriores, também, pode haver algum setor

\footnotetext{
${ }^{262}$ As vendas de equipamentos militares pelos EUA podem ser realizadas através do programa do Departamento de Defesa denominado Foreign Militay Sales, ou diretamente nas empresas fabricantes. Cabe ao presidente dos EUA aprovar os países e organizações que podem adquirir esses equipamentos. O Departamento de Estado sugere a aprovação dos pedidos, caso a caso. Disponível em: http://www.dsca.mil/sites/default/files/fms_faq2_0.pdf. Acesso em: 23 set. 2013.
} 
com o propósito de tentar integrar a "Diplomacia com a Defesa". O grau e o nível dessa coordenação variam, dependendo do país. Entretanto, geralmente existe uma gama de práticas e normas que fica apenas no âmbito da estrutura de Defesa, especialmente aquelas constituídas nas relações entre as Forças Armadas de um país com suas congêneres de outros Estados, como visto no Capítulo 3, quando da descrição dos mecanismos bilaterais e multilaterais.

As práticas sociais relacionadas com a diplomacia de defesa estão disseminadas em escala mundial, sendo conduzidas em maior vulto pelas maiores potências, especialmente os EUA. ${ }^{263} \mathrm{Na}$ sua maioria, têm como fonte a dinâmica da segurança regional, entretanto, existem aquelas de caráter global ou interregional. ${ }^{264}$ Embora algumas possam ser de iniciativa das grandes potências, outras, como é o caso, por exemplo, da Reunião de Ministros da Defesa da ASEAN, foram, inicialmente, constituídas por alguns países da região e, posteriormente, ampliadas para incluir a China. Mais tarde, com a criação do Fórum Regional da ASEAN, outras potências como os EUA e a Rússia se incorporaram ao mecanismo. ${ }^{265}$

O fim da Guerra-Fria aponta para uma expansão da diplomacia de defesa. Apesar de muitos dos seus mecanismos terem se mantido após o fim do conflito ideológico, vários outros foram constituídos a partir dos anos 1990, alguns envolvendo, inclusive, antigos adversários. Os EUA, por exemplo, incrementaram seu relacionamento no âmbito da defesa com a Rússia e a China, buscando avançar a cooperação e reduzir atritos com o primeiro, Estado que foi seu maior oponente naquela "guerra", e com aquele que vem sendo apontado como seu potencial concorrente em um futuro próximo. ${ }^{266}$ Do mesmo modo, diversos fatores contribuíram para que houvesse um avanço da diplomacia de defesa para

\footnotetext{
${ }^{263}$ Apesar da preponderância norte-americana, mecanismos relacionados com a diplomacia de defesa multilaterais no âmbito regional foram se constituindo sem a participação dessa potência, como é o caso, por exemplo, na América do Sul, do Conselho de Defesa Sul-americano. Isso, no entanto, nem sempre representa uma política antiamericana. $\mathrm{O}$ mesmo governo brasileiro que promoveu a criação desse Conselho como uma forma de ganhar um maior papel regional, também promulgou um acordo militar com os EUA que inexistia por quase 40 anos.

${ }^{264}$ Essa predominância dos mecanismos de segurança regional de certa forma enfraquece a crítica de Kaldor de que existe uma tendência de se limitar as consequências das ameaças com foco nos limites dos Estados (KALDOR, 2013, P.131). Para uma abordagem da ideia e da prática da governança regional e sua relação com os processos globais, ver Herz, 2011.

${ }^{265}$ Disponível em: http://aseanregionalforum.asean.org/about.html. Acesso em: 21 fev. 2014.

${ }^{266}$ Para uma análise dessa cooperação, ver Cottey e Foster (2004).
} 
outras áreas associadas ao âmbito civil, como forma de ajudar Estados frágeis ou minimizar problemas relacionados com meio ambiente, catástrofes, epidemias etc.

Principalmente para os EUA, a ajuda a Estados frágeis é tida como uma maneira de garantir que aqueles países sejam direcionados para "a construção de sociedades pacíficas, democráticas e com economia de mercado", e exerçam a soberania sobre seus territórios, a fim de evitar o seu uso por extremistas ou criminosos que possam ameaçar os interesses norte-americanos (US-NSPD 44, p.2005). Como afirmado por Holsti (2004), "se, no passado, a falência da autoridade pública em um território usualmente gerava a anexação, partição, criação ou outras formas de subjugação", nos tempos atuais, o Estado não perde o reconhecimento internacional quanto ao seu status, mesmo quando enfraquecido na sua capacidade de controle de áreas sob sua jurisdição, como é o caso, por exemplo, da Somália.

Assim, o que a comunidade internacional busca, normalmente, "em última instância", é incrementar a autoridade do Estado para que ele possa voltar a ter condições de cumprir suas responsabilidades como membro da sociedade internacional. ${ }^{267}$ Até aqueles com uma visão mais solidarista, que defendem o conceito de segurança humana e a possibilidade de outros arranjos diferentes do Estado, argumentando que "sua fragilidade é, geralmente, a causa primária do conflito", reconhecem a necessidade do fortalecimento da "autoridade política legítima", que possua capacidade de garantir o cumprimento da lei (KALDOR, 2013, p.129-130).

Da mesma forma que as demandas internas geram os Estados multifuncionais, as demandas da sociedade internacional tendem a exigir dela própria essa mesma capacidade, como demonstra, por exemplo, o "dramático incremento nos papéis da ONU em áreas, tais como: diplomacia preventiva, operações de paz, reconstrução de Estados, reconciliação etc.” (ACHARYA, 2008, P.496). Em várias dessas atividades, essa Organização "tem que atender uma série de funções administrativas... e integrá-las com atividades militares,

\footnotetext{
${ }^{267}$ Em situações extremas, como a recente divisão do Sudão, a sociedade internacional pode aceitar a constituição de um novo membro dessa sociedade. Nesses casos, não se estava negando a legitimidade da condição de Estado (Holsti, 2004, p.67) ao Sudão, mas, apenas, a legitimidade para que mantivesse sua autoridade sobre uma parte do país onde a população desejava a separação.
} 
diplomáticas, humanitárias e políticas", o que gera a preocupação com a sua capacidade operacional (HERZ e HOFFMAN, 2004, P.116,126).

Nesse contexto, a diplomacia de defesa joga um importante papel relacionado, principalmente, com o robustecimento da autoridade estatal, pela capacidade das Forças Armadas de executarem operações de paz e contribuírem para a organização e treinamento dos setores ligados à segurança e à defesa dos Estados, ou, complementarmente, atuarem na ajuda humanitária, no desenvolvimento e na "construção ou reconstrução de nações". ${ }^{268}$ Em síntese, dois principais processos se destacam para o incremento do uso dessas Forças no cenário internacional, alimentados pela dinâmica de fragilidade de determinados Estados: a capacidade multifuncional das Forças Armadas e a expansão do conceito de segurança.

A expansão da diplomacia de defesa para essas novas tarefas tem gerado críticas, principalmente nas potências ocidentais e, em especial, nos EUA. Elas estão associadas, por um lado, à crença de alguns de que as Forças Armadas estariam ficando despreparadas para a sua missão primordial de defesa da Pátria ao se dedicarem a tarefas não inerentes ao combate, tendendo a tornarem-se "forças armadas de assistência social"; e, por outro lado, à crença daqueles que consideram que o avanço das organizações de Defesa nessas tarefas estaria militarizando a diplomacia e a ajuda internacional, e dificultando o trabalho das agências civis.

Os argumentos dos que defendem apenas o emprego clássico das Forças Armadas são contestados por alguns fatores conjunturais. Em períodos de menor probabilidade de conflito estatal, há uma tendência à marginalização política dos militares, aos questionamentos quanto aos recursos financeiros destinados ao setor de Defesa e à utilidade das mesmas para a sociedade. ${ }^{269}$ Além do mais, o conceito de segurança humana embute, também, uma crítica aos gastos nesse campo que,

\footnotetext{
${ }^{268} \mathrm{~A}$ partir dos anos 1990 , foi evoluindo a crença de que o desenvolvimento não deveria ser limitado apenas ao crescimento econômico. O conceito de segurança humana desenvolvido pelo Relatório do Desenvolvimento Humano, de 1994, contestava “a visão ortodoxa de desenvolvimento como uma função do crescimento econômico... e propunha o conceito de desenvolvimento humano fundamentado na construção de capacidades para confrontar doenças, pobreza, analfabetismo, discriminações, restrições na liberdade política e ameaças de conflitos violentos" (ACHARYA, 2008, P.492-493).

${ }^{269} \mathrm{~A}$ redução dos orçamentos de defesa dos EUA, por exemplo, já é defendida por alguns autores com a alegação de que "não existem inimigos aparentes" (STIGLITZ e KALDOR, 2013, P.4).
} 
sob essa visão, deveriam ser reduzidos para que se destinassem recursos para outras áreas (ACHARYA, 2008, P.493).

Essas tarefas de cunho social ou relacionadas com o desenvolvimento, normalmente, são consideradas "subsidiárias" ou "secundárias" pelas Forças, cuja missão principal é a defesa contra ameaças externas e que visualizam esses períodos de paz ou como um intervalo entre as guerras (PRIEST, 2004, P.16), ou como um produto da capacidade militar do Estado de enfrentar ameaças. Como, atualmente, para a maioria das Forças Armadas, combater em guerras convencionais é uma das missões menos prováveis a serem cumpridas, elas se vêm, então, em um dilema: não ajudar o Estado multifuncional nessas tarefas "menos nobres" pode significar perda de recursos humanos e materiais e de prestígio doméstico, enquanto que dedicar-se à essas ações não coercitivas com muito empenho, pode contribuir para a perda da sua capacidade de preparação para o combate, com possíveis consequências para o cumprimento da sua missão principal. ${ }^{270}$ Nesse cenário, os militares vão se adaptando, buscando manter a sua preparação para o combate, e utilizando, quando possível, essas tarefas "subsidiárias" como forma de treinamento para o mesmo. Assim, apesar das críticas, essa atuação multifuncional das Forças Armadas tem se generalizado e institucionalizado em muitos países.

Esse avanço da diplomacia de defesa para áreas normalmente de atuação civil se constitui, principalmente, pela capacidade logística e operacional dos recursos da Defesa e no vácuo deixado pelos órgãos responsáveis por essas atividades. No caso dos EUA, esse fenômeno é mais visível no contexto das deficiências de outras organizações, especialmente de um Departamento de Estado "atrofiado", que se vê confrontado com a enorme diferença de recursos à disposição do Departamento de Defesa que conta com Forças Armadas organizadas por comandos militares regionais, funcionando nos moldes interagências, integrando representantes de agências civis. Desta forma, esses comandos têm uma grande capacidade logística e operacional que contribui para incrementar a sua influência diplomática na área onde atuam, a ponto de seus

\footnotetext{
${ }^{270}$ Esse argumento é usado especificamente por Grove ( 1990) em relação à possibilidade das marinhas de guerra se transformarem em guarda-costeiras. Nesta tese, ele é retomado de forma mais ampla para as Forças Armadas em geral.
} 
comandantes serem considerados como os "pró-cônsules modernos" (PRIEST, 2004).

Nessa disputa velada com o Departamento de Estado, o Departamento de Defesa vai se posicionando politicamente de forma ambígua: defende maiores recursos para o setor responsável pela diplomacia e para as agências civis, ao mesmo tempo em que vai ampliando sua participação nas áreas de atuação das mesmas, tentando liderar, efetivamente, o processo de coordenação com essas agências e com as ONGs. Assim, para tentar reduzir as críticas, o Departamento de Defesa instituiu, no Comando Sul e no Comando da África, um cargo de vicecomandante para assuntos civis, ocupado por um embaixador, representando o Departamento de Estado. Nas embaixadas, foi criado o cargo de adido de defesa, cujo ocupante é o assessor do embaixador para coordenação dos temas militares, o que "agradou a muitos embaixadores" (US-OIG, 2009, p.15). Além disso, o papel de assessores diplomatas nas organizações militares passou a ter uma maior abrangência e o Departamento de Defesa estabeleceu um conjunto de normas doutrinárias para facilitar as tarefas e a coordenação entre os setores civis e militares, inclusive com as ONGs. Por outro lado, o Departamento de Estado vai buscando contrabalançar esse processo, através do fortalecimento de suas estruturas organizacionais e do seu corpo normativo, a fim de manter o seu tradicional papel de responsável pela coordenação da diplomacia.

$\mathrm{Na}$ prática, tanto os presidentes democratas, quanto os republicanos, "continuam a usar os militares como a opção preferida do poder nacional em atividades não coercitivas" (REVERON, 2010, P.48), aproveitando as facilidades logísticas, a organização e a cultura do cumprimento da missão que permeiam as Forças Armadas. Após os atentados de 11 de setembro, tal tendência se acentuou, especialmente em relação aos Estados frágeis, com o objetivo de prover segurança, serviços essenciais e ajuda humanitária à população, a fim de contribuir para fortalecer o Estado e suas instituições, em coordenação com outros órgãos civis governamentais. O presidente Bush, para diminuir as resistências, atribuiu a esse tipo de tarefas importância semelhante às tarefas de combate, e o presidente Barack Obama legitimou politicamente essa tendência, ao afirmar que os militares devem ser usados, além das suas missões de combate, "para operações de estabilização e reconstrução de Estados..., a fim de prover a segurança comum que sustenta a estabilidade global” (OBAMA, 2007). 
Esse processo tem contribuído, não apenas para a expansão de tarefas, mas também para um papel mais político da atuação militar. Especialmente nos países frágeis e naqueles que possuem conflitos internos as operações para fortalecer a autoridade política são defendidas fundamentado na necessidade de se tratar sinergicamente os campos político e militar. Nesses casos, como afirmado por David Galuga:

“ Limitar os soldados a funções militares, enquanto tarefas urgentes e vitais necessitam ser realizadas e não existem outros setores disponíveis para executálas seria sem sentido. O soldado deve ser preparado para se tornar um propagandista, um agente social, um engenheiro civil, um professor, um enfermeiro ..." (GALUGA, 2006, P. 62).

Essa visão é compartilhada, inclusive, por Mary Kaldor (2013), ao defender a necessidade das "operações de segurança humana", ou seja, "aquelas que estabilizam a situação, a fim de gerar um espaço seguro que possibilite um processo político pacífico." Ela considera que essas operações devam associar capacidades militares e civis e sejam capazes de garantir um espaço seguro ou minorar as crises provocadas pelos desastres naturais, "operando em nome de um sistema multilateral global". Segundo ela, o comando no nível político deve ser civil, mas no nível operacional existe a necessidade de um único comando, "que pode ser civil ou militar, com capacidade política e acesso à autoridade política". Ao defender a atuação conjunta entre militares e civis, Mary Kaldor, inclusive, contesta as críticas à essa combinação, sob o argumento da necessidade de preservar o "espaço humanitário" que permita o trabalho das organizações que se destinam à ajuda humanitária. Ela afirma que nos conflitos contemporâneos, os civis, inclusive os que trabalham nessas organizações, são alvos da violência e “esse espaço não mais existe” (KALDOR, 2013, P.130-132). Em síntese, como a maior parte das deficiências das instituições estatais se dão, principalmente, em Estados frágeis, “ a segurança humana, na maioria das vezes, só pode ser garantida com o fortalecimento da autoridade estatal” (HOLSTI, 2004, P.71).

A sinergia entre os diversos campos e a necessidade de atuação conjunta entre militares e civis vai ser expressa em diversos documentos, tanto na GrãBretanha, quanto nos EUA, na abordagem denominada "whole of government approach". A Estratégia de Segurança Nacional norte-americana, de 2010, estabelece essa atuação como uma forma de fortalecer a capacidade nacional, 
“incrementando a integração das habilidades e capacidades existentes nas instituições civis e militares, para que elas se complementem e possam operar eficientemente" (US, 2010, P.14). Esse processo contribui para o melhor desempenho do Estado e o incremento do papel e do prestígio das Forças Armadas, que, desta forma, vão ganhando novas atribuições de funções de status, que lhes garante o poder, representado por uma série de obrigações, direitos, responsabilidades, etc., relacionado com as atividades de caráter civil anteriormente mencionadas.

Para o desempenho eficaz dessas funções, os militares necessitam aprimorar determinadas habilidades. Dentre elas, se destaca a capacidade cultural, que tem ganho maior relevo nas Forças Armadas. Os EUA, em especial, têm desenvolvido, nos últimos anos, medidas para incrementar essa capacidade, tanto na formação do pessoal, quanto na assessoria às organizações militares, fundamentadas nas experiências no Iraque e no Afeganistão. Embora seja abordada doutrinariamente de forma pragmática, como uma necessidade para aumentar a probabilidade de sucesso das operações militares, ela ganha o reconhecimento, inclusive, de alguns defensores do conceito de "segurança humana", que consideram que o conhecimento da cultura local, a "comunicação, consulta e diálogo" para lograr informações e estabelecer as ações apropriadas de segurança e desenvolvimento são necessários, não só como uma necessidade moral, mas, também, como forma de ganhar efetividade, "os corações e mentes e fortalecer as forças de segurança locais no longo prazo" (KALDOR, 2013, P.131).

No entanto, seria um exagero afirmar que as Forças Armadas estariam se tornando agências sociais. Existe um processo complexo, difícil de ser resumido por meio de afirmações do tipo "desmilitarização da defesa" ou "militarização da diplomacia". A expansão da diplomacia de defesa está associada, no nível estrutural, às demandas das sociedades, exigindo um papel multifuncional dos Estados e da própria sociedade internacional, da associação entre o desenvolvimento, a segurança e a defesa, da expansão do conceito de segurança, e da interdependência no âmbito internacional. No aspecto conjuntural, está relacionada com a redução da probabilidade do conflito interestatal e à crença de que os recursos humanos e materiais do campo da Defesa podem ser usados em um amplo espectro de tarefas associadas ao âmbito civil, como forma de ajudar 
Estados frágeis ou minimizar problemas relacionados com meio ambiente, catástrofes, epidemias, etc.

Esse processo é mais um sintoma da complexidade com que a diplomacia vem se constituindo e das dificuldades dos órgãos responsáveis pelas Relações Exteriores em coordenar a variedade e a profundidade de temas e tarefas que, principalmente a interdependência tem gerado. Ele simboliza as tensões e contradições do processo democrático relacionado com a subordinação das Forças Armadas aos líderes eleitos pelo povo e a necessidade de coordenação entre os órgãos do governo. O resultado dessa dinâmica, no longo prazo, tanto em relação às questões de eficiência para o combate, quanto nas relações civis e militares, é difícil de se prever.

\section{3}

\section{A diplomacia de defesa e a sociedade internacional}

As práticas sociais relacionadas com o âmbito da Defesa têm se expandido e institucionalizado bilateralmente e multilateralmente no nível global, interregional e, principalmente, regional, para produzir e reproduzir as relações não coercitivas entre os Estados e outras entidades que atuam na política internacional. As interações entre os países se dão no sentido Norte-Norte, NorteSul e Sul-Sul. Elas cumprem as funções de comunicar, buscar e trocar informações, negociar acordos e mecanismos de Defesa, alianças e parcerias estratégicas entre os atores acima citados. Fundamentam-se, geralmente, em interesses comuns e diversos tipos de crenças e ideias compartilhadas, tais como identidades, objetivos, laços históricos, religiosos ou culturais comuns, a prevenção aos conflitos armados, confiança mútua, transparência e cooperação, e relação entre segurança e desenvolvimento, emolduradas pelo princípio da necessidade do fortalecimento do Estado para se autogovernar e contribuir para a ordem e a estabilidade regional e global.

O estudo desse fenômeno sob a ótica do conceito de sociedade internacional mostra que os Estados, em um "ambiente anárquico", foram capazes de constituir uma instituição no âmbito sensível da Defesa, fundamentados em alguns interesses, valores e crenças comuns para conduzir suas relações, sem o 
uso da coerção. Esse fenômeno é denominado nesta tese como diplomacia de defesa, definida como uma instituição da sociedade internacional, que se constitui pela reprodução, no tempo e no espaço, de práticas sociais específicas de agentes oficiais, para construir e reproduzir as relações não coercitivas no âmbito da Defesa entre os Estados e outras entidades que atuam na política internacional.

A análise da diplomacia de defesa mostra que o conceito de sociedade internacional tem um poder explicativo que captura os "elementos de conflito e cooperação na política mundial e as tensões entre a busca pela ordem e a promoção da justiça" (BELLAMY, 2004, P.3). Nesse contexto, Bull foi feliz ao sintetizar essa dinâmica no título do seu livro "A Sociedade Anárquica" 271 e estabelecer que os Estados, conscientes de alguns interesses e valores comuns, e unidos por regras nas relações entre eles, compartilham no funcionamento de instituições. A diplomacia de defesa se insere nessa moldura, como uma instituição que contribui para a manutenção da sociedade internacional, e o seu exame nos possibilita entender melhor a complexidade da política internacional.

Embora possam existir alguns elementos relacionados com a promoção da justiça expressos em documentos de mecanismos bilaterais e multilaterais ou de organizações militares, a maioria das práticas sociais relacionadas à diplomacia de defesa tem como propósito principal garantir a segurança regional e global, inclusive, fortalecendo Estados frágeis. ${ }^{272}$ Essa diplomacia está, portanto, focada na produção e reprodução da ordem e na manutenção da sociedade internacional, formada pelos Estados, que são a sua principal instituição (BULL, 1995, P.68) e, também, agentes que, através das suas ações e interações, geram, desenvolvem, alteram ou tornam obsoletas outras instituições (HOLSTI, 2004, P.26-27).

\footnotetext{
${ }^{271}$ Nessa mesma linha, Holsti (2004) vai afirmar que Wendt foi preciso na sua conclusão de que "anarquia é o que os Estados fazem dela" (WENDT, 1992).

${ }^{272}$ Como visto nos Capítulos 3 e 6, alguns mecanismos, como, por exemplo, a Parceria para a Paz e o Órgão de Política, Segurança e Defesa da Comunidade de Desenvolvimento da África Austral, possuem, nos seus propósitos, uma crença na necessidade de promoção da justiça e dos direitos humanos. Da mesma forma, a "Visão" do Comando Militar Sul dos Estados Unidos, por exemplo, afirma que o "Comando busca a cooperação com os parceiros domésticos e internacionais, a fim de contribuir para desenvolver e garantir a segurança, e promover a prosperidade nas Américas e na comunidade global." Esta mescla entre interesses e valores aparece, também, na sua missão. Embora estabeleça que o Comando deve estar preparado para conduzir um "completo espectro de operações", em apoio aos objetivos de segurança nacional dos EUA, as principais áreas de atuação para o cumprimento da missão são definidas como: "a contenção do crime transnacional; a assistência humanitária, inclusive relacionada com os desastres naturais; o apoio às iniciativas de segurança regional promovidas pelos EUA; o treinamento e os exercícios multinacionais; o engajamento multinacional, não só com os militares, mas, também, com governos e outras agências governamentais; e os direitos humanos". Disponível em: http://www.southcom.mil/ourmissions/Pages/Our-Missions.aspx. Acesso em: 28 mai.2013.
} 
É a existência dos Estados que justifica a própria existência das Forças Armadas, constituídas nos alicerces da hierarquia e da disciplina. Os militares, normalmente, concordam com aqueles que defendem a necessidade de Estados capazes, pelo menos, de manter a ordem nos seus territórios, ou contribuir para a sua manutenção no cenário regional ou global. No âmbito doméstico, a ordem está associada, principalmente, à capacidade do Estado de atender às diversas demandas da sociedade. Fenômeno semelhante ocorre na sociedade internacional, que tem que enfrentar os desafios das inúmeras e variadas ameaças, inclusive daquelas relacionadas com temas, tais como meio ambiente e desastres naturais, catástrofes humanitárias, Estados frágeis, etc. Nesse contexto, as Forças Armadas, que têm se tornado multifuncionais para auxiliar seus governos em diversos tipos de atividades sociais ou relacionadas com o desenvolvimento econômico, normalmente, possuem a capacidade para ajudar a sociedade internacional multifuncional a enfrentar as inúmeras e diversas demandas que a desafiam.

A preocupação com as normas e os valores é uma característica que distingue a Escola Inglesa, por exemplo, da visão neorealista sobre as relações entre os Estados. Bull já apontava nessa direção ao afirmar que existem outros valores além da ordem, e que uma das principais responsabilidades do Estado é harmonizar a ordem com a justiça. Para ele, "a ordem internacional deve ser julgada pela sua contribuição para a ordem mundial" (LINKLATER e SUGANAMI, 2006 P.9-11; 227). Para além das relações de poder, o foco é "analisar o quanto de sociedade existe em cada sistema...consubstanciado nas regras, instituições e valores comuns" (HOFFMAN, 1995, P.viii-ix). Nesse sentido, a diplomacia de defesa contribui para a ordem mundial e para o fortalecimento dos elementos de sociedade existentes nas relações entre os Estados e outras entidades que atuam na política internacional. Fundamentada em alguns interesses, crenças e valores comuns ela se constitui como uma instituição da sociedade internacional através da produção e reprodução de práticas sociais, que favorecem a coexistência pacífica entre os Estados e, algumas vezes, estabelecem as condições de possibilidade para cooperação em outros âmbitos.

A diplomacia de defesa é exercida, entretanto, no contexto dos interesses dos Estados, gerando inconsistências que podem afetar a sua própria efetividade. Em regiões como a Ásia-Pacífico, o Índico e a Europa, ela tem sido usada no contexto do balanço de poder, envolvendo, principalmente, os EUA, a Rússia, a 
Coréia do Sul, o Japão, a China e a Índia. ${ }^{273}$ Embora os EUA tenham incrementado suas relações no âmbito da Defesa com a China e a Rússia, o seu apoio militar ao Japão e à Taiwan e sua atuação em relação ao fortalecimento e expansão da OTAN geram desconfianças em alguns países quanto à efetividade da diplomacia de defesa (COTTEY e FOSTER, 2004). Ela, tem sido preconizada, também, como um importante elemento na disputa entre China e Índia, para que esta ganhe maior influência entre os países do Sul e Sudeste da Ásia (MUTHANNA, 2011).

Da mesma forma, principalmente após os ataques terroristas de onze de setembro os EUA, que nas suas Estratégias de Segurança Nacional publicadas pelos governos Clinton e Bush defendiam o uso dessa diplomacia para a promoção da democracia e do controle civil das Forças Armadas, incrementaram seu apoio a regimes autoritários que ajudassem o governo norte-americano na "guerra ao terror"(COTTEY e FOSTER, 2004), de forma semelhante ao suporte que fora dado a este tipo de governo durante o conflito ideológico que permeou a Guerra Fria. Além do mais, essa "guerra" tem sido usada pelos EUA e seus aliados do grupo conhecido como os "Cinco-Olhos" para espionar, fundamentados em mecanismos da diplomacia de defesa, vários Estados e entidades que atuam na política internacional, utilizando recursos que geram desconfiança e atrito nas relações entre os países. ${ }^{274}$

Assim como na diplomacia, as grandes potências, que têm um maior interesse e responsabilidade na preservação da ordem na sociedade internacional (BULL,1995; WATSON, 1982), possuem uma maior capacidade de influenciar outros países, como é o caso, principalmente, dos EUA e seus aliados, que possuem um papel de destaque na diplomacia de defesa. ${ }^{275}$ Desta forma, eles

\footnotetext{
273 Os EUA e a China jogam um papel ambíguo nessa dinâmica, na qual se mesclam interdependência e conflito de interesses. O governo norte-americano tenta garantir aos seus aliados na região que a assertividade geopolítica demonstrada pela China no âmbito regional será contrabalançada por sua presença e ajuda. Disponível em: http://www.theguardian.com/world/2013/dec/06/joe-biden-seoul-south-korea-china-airspace-row. Acesso em: 16 jan.2014.

${ }^{274}$ Cerca de 35 chefes de Estado e líderes mundiais, inclusive de diversos países aliados dos EUA, tiveram seus telefones vigiados. Disponível http://www.theguardian.com/world/2013/oct/24/nsa-surveillance-world-leaders-calls. Acesso em: 03 fev.2014. Cerca de 38 missões diplomáticas e embaixadas também foram alvo de monitoramento. Disponível em: http://www.bbc.co.uk/news/world-us-canada-23123964. Acesso em: 03 fev.2014.

${ }^{275} \mathrm{O}$ Departamento de Defesa britânico, por exemplo, ressalta a ideia de que o mais importante é a coordenação entre os órgãos militares, o órgão responsável pelas relações exteriores e o
} 
tentam avançar seus interesses mais gerais relacionados com a disseminação e consolidação do modelo liberal de governança (promoção da democracia, economia de mercado, e instituições associadas), e com a necessidade dos países desenvolverem suas capacidades de participação em forças de paz ou contribuírem para a segurança marítima. A própria China, preocupada com a segurança necessária para garantir os seus investimentos na África, tem dado uma maior importância à diplomacia de defesa, que vem se constituindo como um campo que o governo chinês considera que deve ser mais amplamente explorado nas suas relações com os países desse continente. ${ }^{276}$

Algumas vezes, as potências usam essa diplomacia para avançar objetivos mais específicos das suas agendas. Em 2002, por exemplo, os EUA cortaram parte da ajuda militar para Estados membros do Tribunal Penal Internacional que não concordaram em garantir a imunidade, em relação à jurisdição dessa Corte, ao pessoal norte-americano que atuasse nesses países. Segundo o site Coalizão para o Tribunal Penal Internacional, "os EUA continuam a pressionar países ao redor do mundo, com o propósito de concluir acordos bilaterais de imunidade, sob o risco da perda de parte substancial da ajuda militar". ${ }^{277}$

Nesse contexto, os Estados cujas economias são menos desenvolvidas e as estruturas de governo mais vulneráveis podem ser mais facilmente influenciados pelas preferências das grandes potências que lhes conceda ajuda militar representativa no seu orçamento de defesa, como é o caso, por exemplo, da Colômbia e da Indonésia em relação aos EUA (BRUNEAU e TRINKUNAS, 2008, P.17) e da China em relação a alguns países africanos.

Apesar das ambiguidades e tensões, as práticas sociais que constituem a diplomacia de defesa contribuem para a ordem mundial e fortalecem os elementos de sociedade existentes nas relações entre os Estados e outras entidades que atuam na política internacional para além das relações de poder, ao contribuírem para o diálogo entre eles. Esse diálogo possibilita a identificação de valores e interesses

departamento de desenvolvimento internacional, de modo a se obter uma sinergia no campo diplomático, com o propósito de influenciar comportamentos favoráveis à Grã Bretanha e contribuir para evitar crises e conflitos (UK, Ministry of Defense. Paper N.1 Defense Diplomacy. Director General Corporate Communication, London).

${ }^{276}$ Para uma visão completa do texto que trata da importância diplomática que a China confere à África e do papel da diplomacia de defesa, ver a reportagem do China Daily USA, “ Africa will remain important pillar of China's diplomacy", January 06, 2014. Disponível em: http://usa.chinadaily.com.cn/world/2014-01/06/content_17216605.htm. Acesso em: 15 jan.2014.

${ }^{277}$ Disponível em: http://www.iccnow.org/?mod=aspa. Acesso em: 15 jan.2014. 
comuns, a cooperação, inclusive na construção ou reconstrução de Estados frágeis, em uma moldura na qual "a interação entre aqueles mais fortes e mais fracos pode ser desenvolvida em um contexto das regras existentes, dos interesses comuns e das instituições", como defendido por Bull (HOFFMAN, 1995, P.ix).

Apesar do importante papel desempenhado pelas grandes potências, os demais países também contribuem para que a dinâmica relacional da diplomacia de defesa se constitua em um ambiente no qual os Estados "defendam e persigam seus propósitos moderados pelas instituições internacionais" (HOLSTI, 2005, P.306). Muitos dos mecanismos bilaterais e multilaterais que se formaram, principalmente, após a Guerra Fria, se constituíram no âmbito regional ou interregional, promovidos por interesses e crenças comuns desses Estados. Muitos deles, inclusive constituídos no âmbito Sul-Sul. Essas constatações enfraquecem o argumento daquela corrente que visualiza essa diplomacia como um eufemismo que esconderia as aspirações e ações das grandes potências para moldar e controlar as Forças Armadas de outros países, no contexto da disputa em relação aos seus projetos de manutenção da ordem (BARKAWI, 2011).

A diplomacia de defesa aponta, ainda, para uma comunidade internacional com uma cultura militar semelhante, que foi sendo forjada no tempo e no espaço e vem se disseminando desde o século XV, quando as Forças Armadas de vários países foram sendo formadas ou reformadas à imagem das suas congêneres europeias (RALSTON, 1996, RESENDE-SANTOS, 2007) e continuou sendo produzida e reproduzida através das práticas sociais, e reforçada nos centros de estudos militares e nas doutrinas, que são importantes veículos de disseminação das normas. Essa cultura comum contribui para a produção e manutenção da diplomacia de defesa como uma instituição da sociedade internacional.

Como visto no item anterior, principalmente após a Guerra Fria e, especialmente, após os eventos de 11 de setembro, os militares vêm tendo que ampliar a sua capacidade cultural, como parte das adaptações que vão sendo implementadas nas Forças Armadas de vários países, em vista da necessidade de atuarem de forma multifuncional em diversas partes do mundo em ambientes culturalmente distintos. Mesmo que a importância dada à cultura no meio militar tenha como objetivo principal melhorar a probabilidade do sucesso nas operações realizadas, de certa forma, ela contribui, também, para uma visão mais tolerante em relação ao Outro e à diversidade. Assim, os militares vêm incorporando uma 
capacidade cultural que inclui o conhecimento de novas culturas e idiomas, além de uma capacidade de negociação e comunicação que os aproxima da cultura diplomática, o que, aliado ao seu crescente papel nas relações internacionais, tende a torná-los "soldados-diplomatas" (PRIEST, 2004).

A comunidade militar internacional tem tentado se adaptar aos desafios do seu tempo, administrando as tensões entre a cultura militar tradicionalmente voltada para o combate e a socialização, entendida como a incorporação e internalização das normas, para outras tarefas, sem esquecer, entretanto, sua missão principal de defesa da Pátria, razão fundamental da sua existência. Afinal, conforme afirmado por Bull, o conflito armado é outro elemento da política mundial (BULL,1995, P.308), e a guerra é considerada uma instituição da sociedade internacional (BULL,1995, P.xv; HOLSTI, 2005, P.27). Assim sendo, é precoce afirmar que as mudanças operacionais e culturais introduzidas com o papel das Forças Armadas em missões consideradas "subsidiárias" estariam transformando-as "de forças de confrontação" para "forças de cooperação", como sugerido por Reveron (2010).

A Escola Inglesa defende a relação entre uma cultura comum e a sociedade internacional, na medida em que aquela facilita a comunicação e o melhor entendimento entre os Estados, contribuindo para a identificação de valores e interesses compartilhados e para a constituição de instituições compartilhadas que fortalecem a coesão da mesma (BULL, 1995, P.15-16). Pelo menos três questões estão associadas à cultura e essa sociedade: como manter a ordem e a estabilidade em um ambiente de pluralidade cultural; qual o papel das instituições da sociedade de Estados na administração dessa pluralidade; e se essa sociedade está fundada em uma cultura hegemônica, sustentada, inclusive, pelas "discrepâncias no poder material e institucional entre sociedades de diferentes culturas" (O’HAGAN, 2005, P.210).

Como visto acima, uma das conclusões deste trabalho é que a comunidade internacional militar, constituída com uma cultura comum, contribui para a manutenção da ordem e da estabilidade na sociedade internacional, e que existe a ideia, principalmente nos EUA e seus aliados, de que ela facilita a cooperação e a difusão de valores, tais como a democracia e os direitos humanos (BLAIR, 2013), fundamentada na crença de que "os militares compartilham um sentimento único de amizade devido à universalidade da fraternidade militar" (MUTHANNA, 2006, 
P.5). ${ }^{278}$ Além disso, existem, também, indícios de que elementos da cultura militar podem ter repercussões ou ser disseminados no governo e, até mesmo, na sociedade. No passado, por exemplo, reformas de grande vulto introduzidas nas Forças Armadas de alguns Estados, para torná-las semelhantes às suas congêneres da Europa, tiveram um impacto não intencional nas sociedades e nos governos desses países, contribuindo, inclusive, para a disseminação de fatores culturais da sociedade europeia nesses Estados (RALSTON, 1996, P.173-180).

Assim, estudos mais detalhados poderiam ser realizados para uma melhor análise da relação entre a cultura dessa comunidade militar e a sociedade internacional. Nesse aspecto, seria interessante verificar, também, em qual medida o papel preponderante dos EUA na diplomacia de defesa influencia a cultura militar internacional, inclusive, em contraponto com as iniciativas de caráter regional que buscam uma visão própria da ordem regional.

Além da cultura, autores relacionados com a Escola Inglesa consideram que outras estruturas, tais como a econômica e a de gênero, dão apoio e sustentação à sociedade internacional, e sugerem que deveriam ser reconhecidas e analisadas (BELLAMY, 2005). A diplomacia de defesa também tem um papel nesses dois campos. O aspecto econômico-financeiro das estruturas de Defesa são um componente considerável da economia mundial, e as políticas de gênero têm ganhado maior relevo nessa diplomacia, tanto ligadas às forças de paz, quanto à sua introdução e disseminação em mecanismos regionais. ${ }^{279}$ Essas são outras possibilidades de pesquisas que poderiam contribuir para que "a Escola Inglesa incrementasse seu caminho em direção à análise empírica da sociedade internacional”(BELLAMY, 2005, P.294), um dos propósitos desta tese.

Em síntese, a amplitude das práticas, normas e burocratização relacionadas com a diplomacia de defesa, constituídas no tempo e no espaço, aponta para a existência de uma intencionalidade coletiva, que permite aos Estados compartilharem no fazer, no crer e no desejar, e atribuírem funções de status aos

\footnotetext{
${ }^{278}$ Essa ideia de uma fraternidade militar tem sido constituída inclusive em livros, filmes e séries para a televisão, etc. Normalmente, ela está associada ao relacionamento especial que uniria os componentes das Forças Armadas de um país. No entanto, também é usada de forma semelhante para analisar esse tipo de relacionamento entre distintos países em determinados períodos (DAVIS, 1996).

${ }^{279}$ Os ministros da Defesa que participam do Conselho de Defesa da UNASUL, por exemplo, na III Declaração de Lima, em 28 de novembro de 2012, acordaram em "incluir a incorporação da Mulher no âmbito da Defesa, em todos seus níveis, como um tema da agenda do Centro de Estudos Estratégicos de Defesa".
} 
recursos humanos e materiais relacionados com o âmbito da Defesa, inclusive em áreas normalmente de atuação de organizações civis. A natureza não coercitiva do uso dos instrumentos de força, o seu grau de internacionalização e institucionalização, a existência de uma comunidade internacional militar com uma cultura semelhante, são alguns elementos que contribuem para que essa diplomacia tenha características próprias e não deva ser considerada, apenas, uma mera participação das Forças Armadas como um apêndice da diplomacia. Entender as características e dimensões desse fenômeno é importante não apenas pela possibilidade do seu uso instrumental por determinados Estados, como sugerido por alguns autores analisados neste trabalho, mas, principalmente, para entender a complexidade da diplomacia e das instituições da sociedade internacional.

A diplomacia de defesa exerce as três funções fundamentais da diplomacia: reunir informações, comunicar e negociar entre Estados. Além do mais, a rede de adidos, os mecanismos bilaterais e multilaterais, o intercâmbio de militares para servirem em unidades de outros países, as visitas de comitivas e de meios militares, os exercícios conjuntos, a participação em forças de paz e na ajuda à reconstrução de Estados e suas instituições são alguns exemplos da função da diplomacia de defesa que contribuem para minimizar o atrito nas relações internacionais e simbolizam a existência de uma sociedade internacional, com alguns interesses e valores comuns.

Essas práticas sociais são sustentadas por crenças que "justificam as prescrições normativas que postulam certas formas de comportamento ou a mudança do mesmo" (HOLSTI, 2004, P.21-22). Desta forma, a reprodução no tempo e no espaço das práticas sociais específicas de agentes oficiais para produzir e reproduzir as relações não coercitivas no âmbito da Defesa entre os Estados e outras entidades que atuam na política internacional constitui-se numa instituição da sociedade internacional, sub-instituição da diplomacia. Essa sociedade se mantém pela intencionalidade coletiva dos seus membros, que sustenta o consenso nas instituições sociais que a constituem. São elas que, segundo Searle (2008, p.48), incrementam poderosamente a capacidade humana de agir, constituindo-se na "cola que mantém unida as sociedades". 


\section{Referências Bibliográficas}

ACHARYA, AMIYAV. Human Security. In: BAYLIS, John ; SMITH, Steve (Eds.). The Globalization of World politics. New York.: Oxford University Press, 2008. pp. 491-505.

ADLER, Emanuel ; BARNETT, Michael. Security Communities. Cambridge, UK: University Press, 1998.

ÁFRICA DO SUL. Department of Defence \& Military Veterans. Annual Report, Pretória, 2012/2013.

AYOOB, Mohammed. The third world security predicament: state making, regional conflict, and the international system. Boulder, CO : Lynne Rienner Publishers, 1995.

ALLISON, Ghaham ; ZELIKOW, Philip. Essence of Decision. 2.ed United Kingdom: Longman,1999.

ARON, Raymond. Paz e Guerra entre as Nações. Brasília, DF. Editora Universidade de Brasília, 1979.

AVANT, Deborah D.; LEBOVICK, James H. U. S. Military Responses to PostCold War Missions. In: FARRELL, Theo ; TERRIFF, Terry (Eds.) The Sources of Military Change: Culture, Politics, Technology. London ; USA: Lynne Rienner Publishers, Inc. 2002. pp.139-160.

AZEVOV, Xenia, The New Geopolitics of Peace Operations: a Dialogue with Emerging Powers. Katmandu and New Delhi. SIPRI, 2012.

BALL, James. US and UK struck secret deal to allow NSA to 'unmask' Britons' personal data. The Guardian, 20 nov. 2013. Disponível em: http://www.theguardian.com/world/2013/nov/20/us-uk-secret-deal-surveillancepersonal-data. Acesso em: 03 fev. 2014.

BALL, James e HOPKINS, Nick. GCHQ and NSA targeted charities, Germans, Israeli PM and EU chief. The Guardian, 20 dez.2013. Disponível em: http://www.theguardian.com/uk-news/2013/dec/20/gchq-targeted-aid-agenciesgerman-government-eu-commissioner. Acesso em: 03 fev.2014.

BARKAWI, Tarak. "Defence diplomacy" in north-south relations. International Journal 66.3. p.597 (Summer 2011): Academic One File. Web. 23 July 2012. Disponível

em: https://www.academia.edu/985499/_Defence_Diplomacy_in_North_South_Relati ons. Acesso em: 02 jan.2013. 
BARSTON, R. P. Modern Diplomacy. 3.ed. England: Pearson Education Limited, 2006.

BAYLIS, John ; SMITH, Steve (Eds.). The Globalization of World Politics. New York.: Oxford University Press, 2008.

BAYLIS, John ; WIRTZ, James; COHEN, Eliot, GRAY, Colin S. (Eds.). Strategy in the Contemporary World: An Introduction to Strategic Studies. New York.: Oxford University Press, 2006.

BELLAMY, Alex J. (Ed.) International Society and its Critics. Oxford: Oxford University Press, 2005.

BERRIDGE, G.R. Diplomacy: theory and practice. 2.ed. New York: Palgrave, 2002.

BIDEN, Joseph R. J. Defining the Military's Role Toward Foreign Policy. Opening Statement U.S. Senate, Committee on Foreign Relations. Washington, DC.: July,31 2008. Disponível em: http://www.gpo.gov/fdsys/pkg/CHRG110shrg48042/html/CHRG-110shrg48042.htm. Acesso em: 09 mar.2014.

BLAIR, Dennis. Military Engagement. Influencing Armed Forces Worldwide to Support Democratic Transitions. Washington, DC: Brookings Institution Press, 2013.

BLECHMAN, Barry. M. e KAPLAN, Stephen S. Force without war: U.S. armed forces as a political instrument. Washington, DC: Brookings Institutions, 1978.

BÖENE, Bernard and MARTIN, Louis Michael.France: In the Thores of EpochMaking Change. In: MOSKOS, Charles C. WILLIAMS, John Allen e SEGAL, David R. (Eds.) The Postmodern Military. Armed Forces After the Cold War. Oxford: Oxford University Press, 2000.

BOLT, Paul J.; COLETTA, Damon V.; SHACKELFORD, G Jr. (Eds.) American Defense Policy. 8. ed. Baltimore, Md.: The Johns Hopkins University Press, 2005.

BOOTH, Ken ; SMITH, Steve. International relations theory today. Pennsylvania: Pennsylvania State University Press,1995.

BRAILLARD, Philippe. Teoria das Relações Internacionais. Lisboa: Fundação Calouste Gulbenkian, 1977.

BRASIL. Ministério da Defesa. Livro Branco de Defesa. Brasília, 2012. Exército Brasileiro. Estado-Maior do Exército. Operações em Ambiente Interagências. Brasília , DF:2013.

Estratégia Nacional de Defesa. Brasília, DF: 2012 a. 
Escola Superior de Guerra. Manual Básico. Rio de Janeiro: ESG, 1986.

Brasília, DF.[s.d.].

- Departamento de Política e Estratégia. Reuniões internacionais. Conferência de Defesa do Cone Sul, 4, 2008, Brasília. Relatório da Delegação Brasileira. Brasília, DF, 2008.

.Conferência de Ministros de Defesa das Américas, 6., 2004, Equador. Relatório. Brasília, DF, Ministério da Defesa, 2004.

BRASIL. Ministério das Relações Exteriores. II Reunião de Presidentes da América do Sul. Brasília. Nota à imprensa n. 301, de 19 de julho de 2002. Disponível em: http://www.itamaraty.gov.br/sala-de-imprensa/notas-aimprensa/2002/07/19/ii-reuniao-de-presidentes-da-america-do-sul. Acesso em: 14 junho 2011.

Cúpula Extraordinária da União de Nações Sul-Americanas (UNASUL) Costa do Sauípe, Bahia, 16 de dezembro de 2008 - Declaração e Decisões. Nota à imprensa n.700, 16 de dezembro de 2008.

BRIGHI, Elisabetta ; HILL, Chistopher. Implementation and Behaviour. In: SMITH, Steve; Hadfield Amelia; Dunne Tim. Foreign Policy : Theories, Actors, Cases. Oxford: Oxford University Press, 2008, p.117-135.

BRODIE, Bernard. War \& Politics. New York: Macmillan Publishing Co.,Inc.,1973.

BRUNEAU, Thomas; TRINKUNAS, Harold. Global Politics of Defense Reform. New York: Palgrave Macmillan, 2008.

BULL, Hedley. The anarchical society. A study of order in world politics. 2.ed. New York: Columbia University Press, 1995.

BULL, Hedley e WATSON, Adams. The Expansion of International Society. USA: Oxford University Press, 1985.

BUZAN, Barry; WÆVER, Ole. Regions and Powers. The Structure of International Security. Cambridge: Cambridge University Press, 2003.

CAMERON, Fraser. US foreign policy after the cold war. 2.ed. London: Routledge, 2005.

CANADA. The Responsibility to Protect. Report of the International Commission on Intervention and State Sovereignty (ICISS). Otawa: International Development Research Centre, 2001.

CHARNY, Joel R. " The US Military's Expanding Role in Foreign Assistance". Policy Brief. United Voice for Global Change, January, 2013. 
Disponível

em:

http://www.interaction.org/files/FABB\%202013_Sec16_NGOAndMilitaryRelatio ns.pdf. Acesso em: 29 mai.2013.

CHASE, Robert; HILL, Emily; KENNEDY, Paul (Eds.) The pivotal states: a new framework for U.S. policy in the developing world. New York : WW Norton \&Company, 1999.

COPE, John. Defense engagement in peace time: In: BINNENDIJK, Patrick e CLAWSON, Hans (Eds.) Strategic Assessment 1996. Institute for National Strategic Studies. Washington, DC.: National Defense University, 1996.

COTTEY, Andrew ; FORSTER, Anthony. Resheaping defense diplomacy: new roles for military cooperation and assistance. Adelphy Papers n. 365. Oxford: Oxford University Press, 2004.

COUTAU-BÉRGARIE, Hervé. Les Meilleurs des Ambassadeurs. Théorie et Pratique de la Diplomatie Navale. Paris: Economica, 2010.

CÚPULA DAS AMÉRICAS. Declaração da Cidade de Quebec. Quebec, 2001. Disponível em http://www.summitmericas.org/iii_summit/iii_summit_dec_pt.pdf.Acesso em: 13 de junho de 2011.

DANDEKER, Christopher. The United Kingdom: The Overstretched Military. In: MOSKOS, Charles C. WILLIAMS, John Allen e SEGAL, David R. (Eds.) The Postmodern Military. Armed Forces After the Cold War. Oxford: Oxford University Press, 2000.

D'ARAUJO, Maria Celina . Los militares y el desarrollo en América del Sur. In: Marcelo Donadio. (Org.). La reconstrución de la seguridad nacional. Buenos Aires: Prometeo Libros, v. 1, p. 295-307.,2010.

Militares, democracia e desenvolvimento: Brasil e América do Sul. 1. ed. Rio de Janeiro: Editora da Fundação Getulio Vargas,. v. 1. p.268., 2010.

Democratic governments and military in Latin American: Brazil in a comparative perspective. Security and Defense Studies Review, v.4, n.2, Washington, 2004.

DAVIS, Sonny B. A Brotherhood of Arms: Brazil United States military relations 1945-1977. Colorado: University Press of Colorado, 1996.

DER DERIAN, James. Hedley Bull and the Idea of Diplomatic Culture. In Fawn, Rick e Larkins, Jeremi (Eds.) International Society after the Cold War. Great Britain: Macmillan Press Ltd, 1996, pp:84-100.

.On Diplomacy. A Genealogy of Western Estrangement. Oxford: Basil Blackwell, 1987. 
DEUTSCH, Karl. Análise das Relações Internacionais. 2.ed. Brasília: Editora Universidade de Brasília.1982.

DEVIN, Guillaume. Sociologia das Relações Internacionais. Salvador-Ba: EDUFBA/EDUFAL, 2009.

DINIZ, Eugenio (Org.). Estados Unidos: Política externa e atuação na política internacional contemporânea. 1. ed. Belo Horizonte: Ed. Pucminas, v. 1., 543p. 2009.

. Epistemologia, história e estudos estratégicos: Clausewitz versus Keegan.

Contexto Internacional. Rio de Janeiro: PUC-Rio, v. 32, p. 39-90, 2010.

. Relacionamentos multilaterais na unipolaridade: uma discussão teórica realista. Contexto Internacional (PUCRJ. Impresso), v. 28, p. 505-565, 2006.

DODD, Tom; OAKES, Mark. The strategic defense review white paper: research paper 98/91. London: London House of Commons Lybrary, 1998.

DOUGHERTY, James E. ; PFALTZGRAFF, Robert L, Jr. Relações Internacionais:as teorias em confronto. Lisboa: Gradiva, 2003.

DUNNE, Timothy. Inventing International Society: A History of the English School. New York: St. Martin's Press Incorporation.1998.

. The New Agenda. In: BELLAMY, Alex J. (Ed.) International Society and Its Critics. Oxford: Oxford University Press, p.65-79. , 2005.

The Social Construction of International Society. European Journal of International Relations. SAGE, London, Thousand Oaks, CA and Ncw Dclhi: Vol. 1(3), p. 367-389, September,1995.

FALK, Richard. (Re) Imagining the Governance of Globalization. In: BELLAMY, Alex J.(Ed.) International Society and Its Critics. Oxford: Oxford University Press,.p.195-207, 2005.

FIERKE. K.M. Constructivism. In: DUNNE, Tim; KURKI, Milja; SMITH, Steve (Eds.) International Relations Theories-Discipline and Diversity. 2. ed. Oxford: Oxford University Press, 2010.. p.177-194.

FLECKENSTEIN, Bernhard. Germany: Forerunner of a Postnational Military? In: MOSKOS, Charles C. WILLIAMS, John Allen e SEGAL, David R. The Postmodern Military. Armed Forces After the Cold War. Oxford: Oxford University Press, 2000.

FLORES, Mário César. Bases para una política militar: Buenos Aires: Universidade Nacional de Quilmes, 1996. 
GATES, Robert. M. Remarks at 2008 USGLC Tribute Dinner, July 152008. Disponível

em:

Http://www.creativeassociatesinternational.com/CAIIStaff/Dashboard_GIROAdm inCAIIStaff/Dashboard_CAIIAdminDatabase/Resources/Remarks\%20by\%20Secr etary\%20Gates\%20at\%202008\%20USGLC\%20Tribute\%20Dinner.pdf. Acesso em: 08 mar. 2014.

GALUGA, David. Counterinsurgency Warfare. Theory and Practice. Westport, USA: Praeger Security International, 2006.

GALERA, Yann. Reorganization of the Gendarmerie in Macedonia: An Example of European Military Cooperation, 1904-1914. In: RUSH,Robert S. and EPLEY, William W. (Eds.) Multinational operations, alliances, and international Military cooperation. Past and Future. Center of Military History United States Army: Washington, D.C., 2006.

GEORGE, Alexander L.; SIMONS, Williams E. The Limits of Coercive Diplomacy. Boulder: Westview Press, 1994.

GIDDENS, Anthony. A Constituição da Sociedade. São Paulo, Editora Martins Fontes, 2009.

HALLIDAY, Fred. Repensando as relações internacionais. Porto Alegre: Editora da Universidade Federal do Rio Grande do Sul, 1999.

HAMILTON, Keith e LANGHORNE, Richard. The Practice of Diplomacy. Its evolution theory and administration. New York: Routledge, 1995.

HAUGAARD Lisa; Isacson Adam; Withers George; Poe Abigail; Olson Joy, Santos Lucila; Smith Colin. Waiting for Change: Trends in U.S. Security Assistance to Latin America and the Caribbean. A joint publication of the Center for International Policy, the Latin America Working Group Education Fund, and the Washington Office on Latin America.USA, May,2010.

HERZ, M. Regional Governance. In: WEISS, Thomas and WILKINSON, Rorden (Eds.) International Organization and Global Governance. New York: Routledge, 2014. p.236-250.

. Concepts of Security in South America. International Peacekeeping, v. 17, p. 598-612, 2010.

. Política de Segurança dos EUA Para a América Latina Após o Final da Guerra Fria. Estudos Avançados, São Paulo, n.3, 2002.

Análise Cognitiva e Política Externa. Contexto Internacional. Rio de Janeiro, vol.16, n1, jan/jun 1994, p.75-89.

HERZ, Monica; HOFFMANN, Andrea Ribeiro. Organizações internacionais. Rio de Janeiro: Elsevier, 2004. 
HILL, Christopher. The changing politics of foreign policy. New York : Palgrave MacMillan, 2003.

HILSMAN, Roger. The Politics of Policy Making in Defense and Foreign Affairs. New York: Harper and Row, Publishers, 1971.

HIRST, Monica. Brasil - Estados Unidos: desencontros e afinidades. Rio de Janeiro, FGV, 2009.

HOLSTI, K.J. Taming the Sovereigns. Institutional Change in International Politics. Cambridge: Cambridge University Press, 2004.

HOOK, Steven W; SPANIER, John. American foreign policy since World War II. 7. ed. Washington, D.C.: CQ Press, 2007.

HOFFMAN, Stanley. Foreword: Revisiting “The Anarchical Society”. In: BULL, Hedley. The Anarchical Society: A Study of Order in World Politics. 2.ed. New York, Columbia University Press, 1995.

HOGAN, Michael J.; PATERSON, Thomas G. Explaining the history of American foreign relations. 2. ed. Cambridge, UK: Cambridge University Press, 2004.

HUNTER, Wendy. Eroding military influence in Brasil. Chapel Hill and London. The University of Carolina Press, 1997.

ISACSON, Adam and OLSON, Joy: Just the Facts. Latin America Working Group, 1988.

JACKSON, Robert. The Global Covenant. Human Conduct in a World of States. Oxford: Oxford University Press, 2000.

JANOWITZ, Morris. Military Institutions and Coercion in the Developing Nations. Chicago: University of Chicago Press, 1977.

The Professional Soldier. New York: Free Press, 1960.

JOHNSTON, Alastair Iain. The Myth of the ASEAN Way? Explaining the Evolution of the ASEAN Regional Forum. In: HAFTENDORN, Helga; KEOHANE, Robert O. e WALLANDER, Celeste A. (Eds.) Imperfect Unions. Security Institutions over Time and Space. Oxford: Oxford University Press,. p. 287-324.1999.

JORDAN, Amos A.; TAYLOR, William J.; MAZARR, Michael J. American National Security. 5. ed. Baltimore:The Johns Hopkins University Press, 1999.

KALDOR, Mary. Restructuring Global Security for the Twenty-First Century. In: STIGLITZ, Joseph E. and KALDOR, Mary (Eds.) The Quest for Security: Protection Without Protectionism. New York, Columbia University Press, 2013. 
KEGLEY, Charles W. ; WITTKOPF, Eugene R. World Politics: trends and transformation. 8. ed.. Boston : Bedford/St. Martin's, 2001.

KENKEL, K. M.South America's Emerging Power: Brazil as Peacekeeper. International Peacekeeping v. 17, p. 644-661, 2010.

. South America and Peace Operations: Coming of age. New York: Routledge, 2013.

--------. "Global player" ou espectador nas margens? A "Responsabilidade de Proteger": Definição e Implicações para o Brasil. Revista da Escola de Guerra Naval (Ed. português), v. 12, p. 6-57, 2009.

KEOHANE, Robert, O. Cooperation and International Regime. In . LITTLE, Richard ; SMITH, Michael (Eds.). Perspectives on world politics. 2. ed. New York: Routledge, 1991.

KETTL, Donald F. Public Burocracies. In: Rhodes, R.A.W; Binder, Sarah A.; Rockam, Bert A. (Eds.) The Oxford Handbook of Political Institutions. Oxford: Oxford University Press, p.366-367., 2008.

KURBAliJA, J. e SLAVIK, H. (Eds.) Language and Diplomacy. Malta: DiploProjects, Mediterranean Academy of Diplomatic Studies, 2001.

LEWIS, Adrian R. The American Culture of War: A History of Military Force from World War to Operation Iraqi Freedom. New York: Rutledge, 2007.

LIHUA, Qian. Qian Lihua talks about contributions of China's military diplomacy. Ministry of National Defense The People's Republic of China, 28 fev. 2011. Disponível em: http://eng.mod.gov.cn/DefenseNews/201102/28/content_4227439.htm. Acesso em: 09 mar. 2014.

LINKLATER, Andrew e SUGANAMY, Hidemi. The English School of International Relations. Cambridge: Cambridge University Press, 2006.

LIPSCHUTZ, Ronnie D. (Ed.) On Security. New York: Columbia University Press, 1995.

LITTLE, Richard. The English School Contribution to the Study of International Relations. European Journal of International Relations, , 6: p.395- 422., 2000.

The English School and World History. In: BELLAMY, Alex J. (Ed.)

International Society and its Critics. Oxford: Oxford University Press, p.4563.,2005.

LUTTWAK, Edward. The Political Uses of Sea Power. Baltimore and London: John Hopkins University Press, 1974. 
MAIOR, Souto. Luiz A.P. Brasil - Estados Unidos: Desafio de um Relacionamento Assimétrico. Revista Brasileira de Política Internacional, v.44(1): p.55-68., 2001.

MARCH, James G.; OLSEN, Johan P. Elaborating the "New Institutionalism". Oslo: Centre for European Studies. Working Paper, n.1., Mar.2005. Disponível em:

http://web.iaincirebon.ac.id/ebook/moon/PoliticalScience/wp05_11\%20on\%20ins titusionalism.pdf. Acesso em: 20 fev.2014.

MATTINGLY, Garret. Renaissance Diplomacy. UK: Penguin Books,1955.

McCANN JR., Frank D. Jr. A Aliança Brasil Estados Unidos -1937/1945. Rio de Janeiro: Biblioteca do Exército, 1995.

MEERNICK, James David. The Political Use of Military Force in US Foreign Policy. England: Ashgate Publishing Limited, 2004.

MOSKOS, Charles C. WILliAMS, John Allen e SEGAL, David R. (Eds.) The Postmodern Military. Armed Forces After the Cold War. Oxford: Oxford University Press, 2000.

MURRAY, Douglas J.; VIOTTI, Paul R. The defense policies of nations: a comparative study. 3. ed. Baltimore : The Johns Hopkins University Press, 1994.

MUTHANNA, Colonel KA. Enabling Military-to-Military Cooperation as a Foreign Policy Tool: Options for Índia. United Service Institution of Índia Centre for Research. New Delhi: Knowledge World, 2006.

-----. Military Diplomacy. Journal of Defence Studies. v. 5., n1. Jan., 2011.

NAVARI, Cornelia. The concept of practice in the English School. European Journal of International Relations, 17(4), p.611-630., 2010.

NEUMANN, Iver B. The English School on Diplomacy: Scholarly Promise Unfulfilled. International Relations, v.17, p. 341-369., 2003.

The Body of the Diplomat. European Journal of International Relations. v. 14(4), p. 671-695. 2008.

NOGUEIRA, João Pontes e MESSARY, Nizar. Teoria das Relações Internacionais - Correntes e Debates. Rio de Janeiro, Elsevier, 2005.

NYE, Joseph S, Jr. Understanding international conflicts. New York : Longman, 1997.

OBAMA, Barack. Renewing American Leadership. Foreign Affairs, July-August 2007. Disponível em: http://www.foreignaffairs.com/articles/62636/barackobama/renewing-american-leadership. Acesso em: 11dez.2014. 
ORGANIZAÇÃO DO TRATADO DO ATLÂNTICO NORTE. Active Engagement, Modern Defence. Strategic Concept. Lisbon, 19-20 November, 2010.

O'HAGAN, Jacinta. The Question of Culture. In: BELLAMY, Alex J.(Ed.) International Society and Its Critics. Oxford: Oxford University Press, 2005.

PIGMAN, Geoffrey Allen. Contemporary Diplomacy. Cambridge: Polity Press, 2010.

PINHEIRO, Leticia; MILANI, Carlos R.S. (Orgs.) Política Externa Brasileira. As práticas da política e a política das práticas. Rio de Janeiro: Editora FGV, 2012.

PLESSIS, du Anton. Defense Diplomacy: Conceptual and Practical Dimensions with Specific Reference to South Africa. Strategic Review for Southern Africa. Nov, 2008.

PLOCH, Lauren. Africa Command: U.S. Strategic Interests and the Role of the U.S. Military in Africa. Washington: Congressional Research Service (7-5700), Jun.2011.

PRIEST, Dana. The Mission. New York: WW. Norton \&Company, 2004.

RALSTON, David B. Importing The European Army. The Introduction of European Techniques and Institutions into the Extra-European World, 1600-1914. Chicago: The University of Chicago Press, 1990.

RESENDE-SANTOS, João. Neorealism, States and The Modern Mass Army. Cambridge: Cambridge University Press, 2007.

REVERON, Derek S. Exporting Security. Washington, DC: Georgetown University Press, 2010.

RIBANDO, Clare M. Brazil - US relations: CRS Report for Congress. Washington, DC. 2007

RICE, Condoleezza. Promoting the National Interest. Foreign Affairs, v.79, Jan./Feb, 2000.

RICKS, Thomas. The Widening Gap Between the Military and Society. Atlantic Monthly, p. 67-88.; July 1997.

ROCHA, A. J. R, FELDMANN, A. ; LENGYEL, M. ; MALACALZA, B. Lost in Translation: ABC Cooperation and Reconstruction in Haiti. Journal of Peacebuilding \& Development, v. 6, p. 45-60, 2011.

ROCHA, A. J. R. . Política Externa e política de defesa no Brasil: civis e militares, prioridades e a participação em missões de paz. E-cadernos CES (Online), v. 6, p. 142-158, 2009. 
O sistema político dos EUA: implicações para suas políticas externa e de

defesa. Contexto Internacional, Rio de Janeiro, v. 28, n.1, p. 53-100, 2006.

ROSEN, Stephen Peter. Winning the Next War. Ithaca and London. Cornell University Press, 1991.

ROSENAU, J. Change, complexity and governance in a globalizing space. In J. Pierre (Ed.) Debating Governance: Authority, Steering and Democracy. Oxford: Oxford University Press, p.169-200,2000.

RUGGIE, Jonh Gerard. What Makes the World Hang Together? NeoUtilitarianism and the Social Constructivist Challenge. International Organization, v. 52, n. 4, International Organization at Fifty: Exploration and Contestation in the Study of World Politics. p. 855-885. Autumn, 1998.

RUPP, George. Defining the Military's Role towards Foreign Policy. Testimony Before the United States Senate Committee on Foreign Relations.Washington, DC.July 31, 2008. Disponível em: http://www.rescue.org/sites/default/files/migrated/help/take-

action/resources/irc_testimony_militaryforeignrelations_rupp.pdf. Acesso em 11jun.2013.

SILVA, A. R. A. A Marinha e as Novas Ameaças. Revista da Escola de Guerra Naval, Rio de Janeiro, p. 32-42, jun. 2006.

SARKESIAN, Sam C. ; WILLIAMS, John Allen ; CIMBALA, Stephen. US National Security. Boulder, NV: Rienner Publishers, 2008.

SCHELLING, T. C. Arms and Influence. New Haven; London: Yale University Press, 1966.

SEARLE, John R. Philosophy in a New Century. Cambridge: Cambridge University Press, 2008.

The Construction of Social Reality. New York: The Free Press, 1995.

SHARP, Paul. Diplomatic Theory of International Relations. Cambridge: Cambridge University Press, 2009.

SIMPSON, Smith. The crisis in American diplomacy: shots across the bow of the State Department. EUA: Christopher Pub House, 1980.

SMITH, Paul J. Transnational Security Threats and State Survival: A Role for the Military. Parameters.p.77-91. Autumn, 2000.

SMITH, Steve; Hadfield Amelia and Dunne Tim. Foreign Policy : Theories, Actors, Cases. Oxford: Oxford University Press, 2008. 
SPEAR, Joanna, WILLIAMS, Paul D. (Eds.) Security and Development in Global Politics: A Critical Comparison. USA: Georgetown University Press, 2012.

STAIN, Arthur A. Why Nations Cooperate. Ithaca,Nyu: Cornell University Press, 1990.

STEPHAN, Alfred. Rethinking military politics. Princeton, NJ: Princeton University Press, 1988.

STEPHENSON, James. Whole of Government in Diplomacy and Development: Whole or Hole?. In: Frank, Volker C. e Dorff, Robert H. Conflict Management and "Whole of Government": Useful Tools for US National Security Strategy? Carlisle: Strategic Studies Institute,p. 217-230, 2012.

STEVENSON, Charles A. SECDEF: the nearly impossible job of Secretary of Defense. Washington, DC.: Potomac Books, Inc., 2007.

STIGLITZ, Joseph E. and KALDOR, Mary (Eds.) The Quest for Security: Protection Without Protectionism. New York: Columbia University Press, 2013.

STOKER, Donald. Military Advising and Assistance: From Mercenaries to Privatization, 1815-2007. Routledge, New York, 2008.

TUCK, Richard. The Rights of War and Peace. Political Thought and the International Order from Grotius to Kant. Oxford: Oxford University Press, 1999.

TZU, Sun. A Arte da Guerra. Rio de Janeiro, Record, 1983.

UNITED KINGDOM. Army Doctrine Publication- Operations. London: November, 2010.

Secretary of State for Defense. Strategic Defense Review, London: Chapter 3. Jul.,1998.

Department for International Development, Foreign and Commonwealth Office and Ministry of Defence. Bulding Stability Overseas Strategy, 2011.

. Ministry of Defence. International Defence Engagement Strategy Published 6 Feb. 2013. Disponível em: https://www.gov.uk/government/publications/international-defence-engagementstrategy. Acesso em: 09 mar. 2014.

UNITED NATIONS. Human Development Report 1994. United Nations Development Programme (UNDP). Oxford University Press: New York e Oxford, 1994.

.Potential Uses of Military-Related Resources for Protection of the Environment. New York: United Nations, 1993. 
1982.

.United Nations on the Law of the Sea. United Nations, New York,

.Vienna Convention. Disponível em:

http://untreaty.un.org/ilc/texts/instruments/english/conventions/9_1_1961.pdf.

Acesso em: 09 mar.2014.

UNITED STATES. White House Office. Defense Ministerial of the Americas.

Washington, DC.: 1995.

. White House. National Security Presidential Directive/NSPD-44.

Washington, DC. December 7, 2005

The National Security Strategy of The United States of America.

Washington, DC.: October,1998.

The National Security Strategy of The United States of America.

Washington, DC.: Sept., 2002.

UNITED STATES. Congress. CRS Report for Congress. The Department of Defense Role in Foreign Assistance: Background, Major Issues, and Options for Congress. Washington,D.C: 25 August, 2008

US Code. The Arms Export Control Act (AECA). Section 2751.

UNITED STATES. Department of the Army. Memorandum for Chief, Training Development Division (TDD). Directorate of Training Development (DOTD), Maneuver Center of Excellence (MCoE), Fort Benning, GA 31905. Ago,2013. Disponível em: http://www.benning.army.mil/mcoe/maneuverconference/content/pdf/TDD\%20$\% 20$ Memo\%20$\% 20 \% 20$ LREC\%20Strategy\%20Document\%20Dated\%2019\%20Aug\%202013.p df. Acesso em: 12 dez.2013.

UNITED STATES. Department of Defence. Defence Language Transformation Roadmap. Washington, DC. Jan. 2005.

Directive number 3000.05. Military Support for Stability, Security, Transition and Reconstruction (SSTR) Operations. November 28, 2005.

.Government Accountability Office. Report to Congressional Committees. Humanitarian and Development Assistance. Project Evaluations and Better Information Sharing Needed to Manage the Military's Efforts. Washington, February, 2012.

Instruction number 3000.05. Stability Operations. September 16, 2009.

UNITED STATES. Joint Chief of Staff. Joint Publication 1-02, Department of Defense Dictionary of Military and Associated Terms. 8 Nov. 2010 (As Amended Through 31 Jan.2011). 
.Joint Doctrine For Military Operations Other Than War. Washington, DC, 1995.

.Handbook for Military Participation in the Interagency Management System for Reconstruction and Stabilization. February, 2010.

UNITED STATES. USN. Chief of Naval Operations. Opnav. Instruction 5711.96C. 10 Nov. 2008.

.U.S. Navy Language Skills, Regional Espertise and Cultural Awareness Strategy. Washington, DC. January, 2008.

.SOUTHCOM. United States Southern Command Strategy 2016.

UNITED STATES. State Department. Office of Inspector General. The Bureau of African Affairs. Report Number ISP-I-09-63. August 2009.

Stavridis, James G. The Last Hour ... Or the First?. Remarks at Americas Quarterly Launch. New York, October 22, 2007.

VAGTS, Alfred. Defense and Diplomacy. The soldier and the conduct of foreign relations. New York: King's Crown Press, 1956.

The Military Attaché. Princeton, N J: Princepton University Press, 1967.

VAZ, Alcides Costa. Cooperação, Integração e Processo Negociador: a construção do Mercosul. Brasília, DF.: Universidade de Brasília, Instituto Brasileiro de Relações Internacionais, 2002

Percepciones no Brazil sobre o conflicto colombiano e de seus reflexos regionais e nas relações bilaterais: uma visão preliminar. Revista Colombia Internacional. n. 60, p. 36 - 51. Julio - Diciembre, 2004

VAN CREVELD, Martin. Technology and War. From 2000 B.C. to the Present. UK, Brassey's, 1991.

.The Trainning of Officers - From Military Professionalism to Irrelevance. NewYork, The Free Press, 1990.

VIDIGAL, Armando Amorim Ferreira Vidigal. A evolução do pensamento estratégico naval brasileiro. Rio de Janeiro, Biblioteca do Exército, 1985.

VIOTT, Paul R. American foreign policy and national security: a documentary record. Pearson,N J: Prentice Halll, 2005.

WATSON, Adams. A Evolução da Sociedade Internacional. Brasília, Editora Universidade de Brasília, 2004.

Diplomacy: The Dialogue between States. London, Methuen, 1982. 
European International Society and Its Expansion. In: BULL, Hedley e WATSON, Adam (Eds.) The Expansion of International Society. New York, Oxford University Press, p.13-30. 1985

WEBBER, Mark; SMITH, Michael. Foreign policy in a transformed world. New York: Prentice Hall, 2002.

WENDT, Alexander. "Anarchy is What States Make of It: The Social Construction of Power Politics". International Organization. n.46, 2, p. 391425., 1992.

WIGHT, M. International Theory: The Three Traditions. WIGHT, M. WIGHT, Gabriele e PORTER, Brian (Eds.), London: Leicester University Press, 2001.

ZEGART, Amy B. Flamed by design. Stanford, CA: Stanford University Press, 1999.

ZINNI Tony e KOLTZ, Tony. The Battle for Peace - A Frontline Vision of America's Power and Purpose. New York: Palgrave, 2006. 